\title{
Fundação de São Paulo, de Oscar Pereira da Silva: trajetórias de uma imagem urbana
}

\author{
Michelli Cristine Scapol Monteiro
}

Orientador: prof. Dr. Paulo César Garcez Marins

Dissertação de Mestrado

História e Fundamentos da Arquitetura e do Urbanismo

Faculdade de Arquitetura e Urbanismo

Universidade de São Paulo 
AUTORIZO A REPRODUÇÃO E DIVULGAÇÃO TOTAL OU PARCIAL DESTETRABALHO, POR QUALQUER MEIO CONVENCIONAL OU ELETRÔNICO, PARA FINS DE ESTUDO E PESQUISA, DESDE QUE CITADA A FONTE.

E-MAILAUTORA: michellicris@yahoo.com.br

Monteiro, Michelli Cristine Scapol

M775f Fundação de São Paulo, de Oscar Pereira da Silva: trajetórias

de uma imagem urbana / Michelli Cristine Scapol Monteiro. --São

Paulo, 2012.

175 p. : il.

Dissertação (Mestrado -Área de Concentração: História e

Fundamentos daArquitetura e Urbanismo)-FAUUSP.

Orientador: Paulo César Garcez Marins

1.Pintura (Representação) - São Paulo, SP 2.História urbana

3.Imaginário 4.Silva, Oscar Pereira da, 1865-1939 I.Título

CDU75(816.11) 


\section{RESUMO}

\section{Fundação de São Paulo, de Oscar Pereira da Silva: trajetórias de uma imagem urbana}

Esta dissertação tem por tema o estudo do circuito social de uma pintura histórica voltada à representação urbana. Trata-se da tela Fundação de São Paulo, concluída pelo pintor brasileiro Oscar Pereira da Silva em 1907, e pertencente ao acervo do Museu Paulista da Universidade de São Paulo. Produzida em um momento em que o sucesso político e econômico das elites dirigentes paulistas era associado à construção de um passado heróico para a capitania de São Vicente e de São Paulo, esta pintura integra-se ao processo de produção de representações iconográficas que tinham por intenção oferecer uma narrativa visual sobre esse passado. Sua musealização permitiu um contínuo processo de apropriação social, que permitiu integrá-la ao imaginário paulistano e paulista. Percorrer o circuito desta pintura (composto por sua concepção/realização, exposição, fortuna crítica,aquisição, musealização e reprodução) é o objetivo deste trabalho, tendo em vista que a obra é um dos principais suportes da representação de momentos fundadores de espaços urbanos produzidos no Brasil republicano e peça fundamental no corpus de imagens que embasaram um imaginário nacional, paulista e paulistano.

PALAVRAS-CHAVE: Representação, imaginário, São Paulo (cidade), história urbana, pintura histórica, Oscar Pereira da Silva

\section{Fundação de São Paulo, by Oscar Pereira da Silva: trajectories of an urban image}

The theme of this dissertation is the study of the social circuit of a historical painting with a urban representation motif. It discusses the painting Fundação de São Paulo, concluded by the Brazilian painter Oscar Pereira da Silva in 1907, and belonging to the collection of the University of São Paulo's Museu Paulista (São Paulo Museum). Produced in a moment in which the political and economic success of the São Paulo ruling upper classes was associated with the construction of a heroic past for the São Vicente and São Paulo captaincies, this painting integrates itself with the production process of iconographical representations that intended to offer a visual narrative for this past. Its museumization permitted a continuous social appropriation process, that allowed its integration with the São Paulo state's and city's imagery. To browse through this painting's content (composed by its conception/production, exposition, critic fortune, aquisition, museumization and reproduction) is this work's goal, since the picture is one of the main sustainment of the representation of founding moments in urban spaces produced in republican Brazil, and keystone to the images' corpus that supported an imagery for the country, the state and the city.

KEY-WORDS: representation, imagery, São Paulo (city), urban history, historical painting, Oscar Pereira da Silva 


\section{AGRADECIMENTOS}

Em primeiro lugar, agradeço meu orientador, o professor Paulo César Garcez Marins, que com grande brilhantismo e seriedade me introduziu ao ofício de historiador. Foi quem vibrou com cada descoberta, com cada hipótese, com cada novo documento. Acompanhou de perto passo a passo dessa pesquisa, sem poupar elogios e incentivos. Sua orientação foi essencial para o sucesso dessa dissertação.

As pessoas a quem devo agradecimento eterno são meus pais - os meus alicerces. Foram eles que forneceram insumo para que eu me transformasse no que sou e pudesse concretizar meus sonhos. Ao meu pai, José Luiz, que, apaixonadamente, despertou meu gosto pela leitura e pelo conhecimento. É a pessoa com quem tantas vezes troco discussões acaloradas de história. À minha mãe, Arlete, meu porto seguro, que, pacientemente, ouviu-me nas horas de incerteza e insegurança. Foi ela a primeira leitora de todos os meus textos, hoje e sempre. À minha querida irmã, Lilian, que serviu de exemplo de dedicação e me mostrou que, com competência, nenhum sonho é inalcançável.

Tenho muita gratidão a todos os professores que acompanharam a minha trajetória e recomendaram ótimas indicações bibliográficas, como Maria Cecília França Lourenço, Lilia Schwarcz e Ana Paula Cavalcanti Simioni. Dentre eles, devo agradecimento especial aos que participaram da minha banca de qualificação, professora Ana Duarte Lanna e professor John Monteiro, que enriqueceram esse trabalho, pois indicaram novos rumos possíveis, que permitiram uma análise mais aprofundada e precisa.

Sou grata à FAPESP, que financiou esta pesquisa, subsídio imprescindível, pois permitiu que eu me dedicasse inteiramente ao seu desenvolvimento. Tenho muito a agradecer também às pessoas que me atenderam, sempre com grande profissionalismo, nos locais em que realizei a pesquisa, principalmente, no Arquivo do Estado de São Paulo, no Museu Paulista, na Biblioteca Mario de Andrade, na Assembleia Legislativa de São Paulo, no Arquivo da Cúria, na Pinacoteca do Estado de São Paulo, no Museu da Santa Casa da Misericórdia e nas diversas bibliotecas da USP.

Agradeço a todos meus amigos, com quem pude compartilhar minhas expectativas e experiências. Àqueles de sempre e pra sempre, Sandra, Karen, Paula, Mariana, Andrea e Marcio. Aos companheiros de jornada acadêmica Carlos, Vivian, Adriana, Helo, Tai, Greg, Renata, Juliana, Tatiana, Amanda, Victor e Marcel. Aos 
amigos geógrafos, Caio, Bruno, Miti, Julia e Gil. A todos meus familiares, antigos e novos, que acompanharam, com muita curiosidade e respeito, esse trabalho.

O maior agradecimento, entretanto, é ao João Lucas, meu companheiro de todas as horas, meu amigo inseparável. Foi ele que tornou esse percurso mais tranquilo e gratificante. Agradeço por ter sido paciente e ter aturado tantas vezes a minha ausência. Agradeço por me abraçar quando precisei, por silenciar quando pedi, por correr quando chamei. Foi ele que esteve sempre ao meu lado e, com palavras de incentivo, encorajou-me a seguir a carreira acadêmica. $E$, agora, sela o compromisso de envelhecer ao meu lado e, portanto, acompanhar todas as empreitadas que ainda estão por vir. Mal posso esperar...

A todos, muito obrigada! 


\section{Sumário}

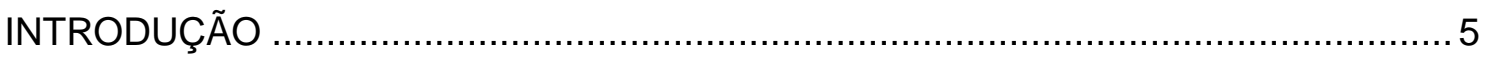

CAPÍTULO 1- Fundando a urbe: reelaboração de um modelo pictórico........................ 18

Um artista fluminense na capital do café ....................................................... 19

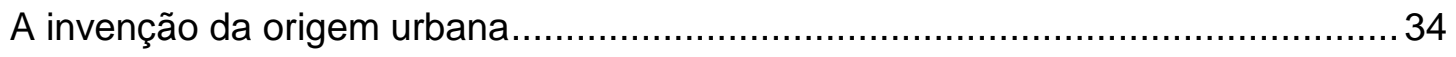

A cidade que nasce da submissão ............................................................... 51

Capítulo 2 - Entre História e Arte: recepções em conflito .......................................6 65

A difícil aquisição ................................................................................... 75

Museu Paulista ou Pinacoteca do Estado? ...................................................... 93

CAPÍTULO 3 - Uma janela para vários passados: do museu para a cidade .............. 105

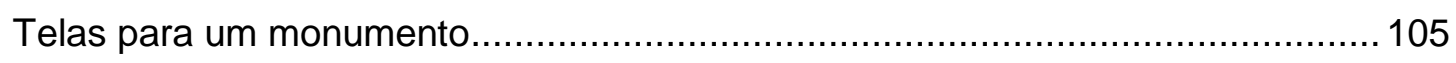

Uma transferência indesejada? ................................................................ 111

A inadequação de uma imagem adequada ..................................................... 119

Triunfo de uma imagem urbana.............................................................. 127

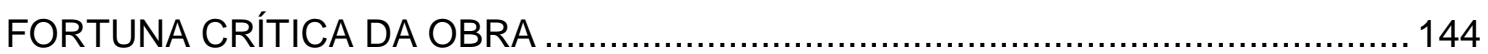

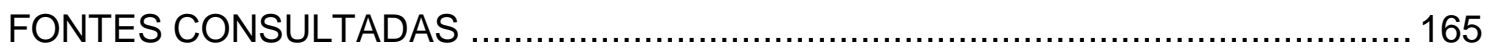

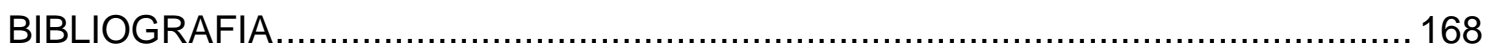




\section{INTRODUÇÃO}

A pintura histórica foi um importante mecanismo na construção de mitos e heróis no Ocidente pós Revolução Francesa. Por seu caráter didático, ela foi capaz de despertar o apoio da população, por meio de relações afetivas e simbólicas, aos projetos políticos das elites dirigentes. Tal gênero artístico serviu, assim, de instrumento para a legitimação do poder, para a transmissão de valores cívicos e para a construção da história, já que permite fixar sínteses simbólicas de alto impacto, como indicou Meneses". Ela fornece suporte para grande parte da "invenção das tradições" $^{2}$ e para criar um sentimento de pertencimento ${ }^{3}$, característica esta que tornoua pintura histórica,tanto na Europa quanto nas Américas, um meio eficaz de construção do mundo social e de definição das identidades.

Atenta a tais premissas, esta dissertação de mestrado tomou como objeto privilegiado de análise o quadro Fundação de São Paulo, de Oscar Pereira da Silva, concluído em 1907. Realizada em um período em que as elites paulistas assumiam a liderança no cenário político nacional, a tela vincula-se à construção do passado paulista e paulistano, que deveria ser dotado de glória e grandiosidade, correspondente à ascensão política e econômica dos cafeicultores. A pintura histórica tornava-se, assim, um poderoso instrumento capaz de legitimar a posição ocupada por essas elites, constituindo-se como "lugar de memória", já que tinha o poder de idealizar cenas do passado, de modo a poderem ser consideradas dignas de compor 0 imaginário da sociedade. A tela de Oscar Pereira da Silva inseria-se nesse contexto de afirmação de uma identidade paulista, de construção da origem de São Paulo, tornando-se suporte de formulação e retenção da memória coletiva.

\footnotetext{
1 MENESES, Ulpiano T. Bezerra de (org.). Como explorar um museu histórico. São Paulo: Museu Paulista/USP, 1992, p. 22.

2 Segundo Hobsbawn, por "tradições inventadas" entende-se um conjunto de práticas, normalmente governadas por regras tácitas ou abertamente aceitas. Tais práticas de natureza ritualística ou simbólica visam inculcar certos valores e normas de comportamento através da repetição ou sistematização que implicam, automaticamente, uma continuidade em relação ao passado. HOBSBAWM, Eric J; RANGER, Terence O. The invention of tradition.Cambrigde: University Press, 2000.

${ }^{3}$ Benedict Anderson propõe a seguinte definição de nação: "uma comunidade política imaginada". Para ele,as narrativas nacionais deveriam abranger a todos e ser capaz de criar um vínculo, uma comunhão. Dessa maneira, independentemente da desigualdade e da exploração efetivas que possam existir dentro da nação, ela sempre é concebida como uma profunda camaradagem horizontal. ANDERSON, Benedict. Comunidades imaginadas. São Paulo: Companhia das Letras, 2007.
} 
Pierre Nora ${ }^{4}$ aponta para a prática crescente na França, desde o século XIX, de consagrar espaços em que a memória pudesse se fixar e se cristalizar. Os chamados "lugares de memórias" são configurados em situações em que os ambientes de memória gerados secularmente nas práticas sociais se desagregam, permitindo assim que "quanto menos a memória é vivida do interior, mais ela tem a necessidade de suportes exteriores e de referências tangíveis de uma existência que só vive através delas" 5 . Nora considera como "lugar de memória" toda unidade significativa, de ordem material ou ideal, que se transformou em elemento simbólico da memória de uma comunidade, que se transfigura numa representação no mais das vezes oficializada. Toda obra histórica é um lugar de memória, assim como todo grande acontecimento pode sugerir representações. "A memória pendura-se em lugares, como a história em acontecimentos" ${ }^{6}$. Nora chama a atenção para os acontecimentos que, por vezes, são ínfimos, porém, o futuro retrospectivamente lhe confere a grandiosidade das origens, a solenidade das rupturas inaugurais. Esses acontecimentos eram selecionados e serviam de tema para os quadros de história, queeram, eles próprios, suporte da memória.

Além de se configurarem como "lugares de memória", as telas são entendidas, neste trabalho, como representação, tal como postulou Roger Chartier ${ }^{7}$. Ele afirma que a história cultural preocupa-se em identificar como em diferentes lugares e momentos uma determinada realidade social é construída e pensada. Afirma ainda que as percepções do social não são discursos neutros, já que produzem estratégias e práticas que tendem impor uma autoridade ou legitimar um projeto reformador. As representações são, assim, matrizes de discursos e práticas diferenciadas que tem por objetivo a construção do mundo social e a definição das identidades, uma vez que permitem conciliar imagens mentais claras com esquemas interiorizados. Embora elas aspirem à universalidade de um diagnóstico fundado na razão, são sempre determinadas pelos interesses de grupo que as forjam. Por isso, é preciso relacionar os discursos proferidos com a posição de quem os utiliza. Uma vez que as lutas de representação são importantes para entender os mecanismos pelos quais um grupo impõe, ou tenta impor, a sua concepção do mundo social.

\footnotetext{
${ }^{4}$ NORA, Pierre. Entre Memória e História: a problemática dos lugares. Revista Projeto História,São Paulo, no 10, 1993; NORA, Pierre; AGERON, Charles-Robert. Les lieux des mémoire. Paris: Gallimard, 1997.

${ }^{5}$ NORA, Pierre. Entre Memória e História: a problemática dos lugares. Revista Projeto História, São Paulo, no 10, 1993, p. 14.

${ }^{6}$ Idem, p. 25.

${ }^{7}$ CHARTIER, Roger. O mundo como representação. Estudos Avançados,São Paulo, n.11(5), p.173-191, 1991. CHARTIER, Roger. A história cultural: entre práticas e representações. Lisboa: DIFEL, 1990.
} 
A representação, por um lado, faz ver um objeto ausente por meio de sua substituição por uma imagem capaz de o reconstruir em memória, por outro lado, é uma exibição da presença, como apresentação pública de algo a alguém. A representação é entendida, portanto, como relacionamento de uma imagem presente e de um objeto ausente, valendo aquela por este. Para que essa relação seja inteligível; é necessário o distanciamento com a coisa significada, além da existência de convenções partilhadas.

Chartier demonstra que a noção de representação articula três modalidades da relação com o mundo social: o trabalho de classificação e delimitação por meio das quais a realidade é contraditoriamente construída pelos diferentes grupos; as práticas que visam fazer reconhecer uma identidade social e significar simbolicamente um estatuto e uma posição; e as formas institucionalizadas e objetivadas graças às quais uns "representantes" marcam de forma visível e perpetuada a existência do grupo. As estruturas do mundo social não são um dado objetivo, são historicamente produzidas pelas práticas articuladas que constroem as suas figuras. Assim,analisar pinturas históricas, entendidas como representação,é integra-las à compreensão de como diferentes segmentos da sociedade as produziram e apropriaram-se delas.

A vida social é produtora de valores e normas e, ao mesmo tempo, de sistemas de representações que as fixam e as traduzem. As representações coletivas são utilizadas para legitimar o exercício do poder, designadamente o poder político, que impõe como lugar estratégico o domínio do imaginário e do simbólico. Como salientou Bronislaw Baczko ${ }^{8}$, qualquer sociedade precisa imaginar e inventar a legitimidade que atribui ao poder, apoderando-se do controle dos meios que formam e guiam a imaginação coletiva. A fim de impregnar as mentalidades com novos valores e fortalecer a sua legitimidade, o poder tem designadamente de institucionalizar um simbolismo e um ritual novos.

Baczko afirma que, por meio dos seus imaginários sociais, uma coletividade designa a sua identidade e elabora uma certa representação de si. O imaginário social é, deste modo, uma peça efetiva e eficaz do dispositivo de controle da vida coletiva. Ele se torna inteligível e comunicável através da produção dos "discursos" nos quais se efetua a reunião das representações coletivas numa linguagem, como as imagens, que são apresentadas por meio da arte. Um só e mesmo código permite fazer concordar as expectativas individuais, exprimir as coincidências e as contradições

\footnotetext{
${ }^{8}$ BACZKO, Bronislaw. Imaginário social. In ROMANO, Ruggiero (org.). Enciclopédia Einaudi, volume5: Anthropos-Homem . Lisboa: Imprensa Nacional; Casa da Moeda, 1985, p. 296 - 332.
} 
entre as experiências e as esperanças, e ainda sustentar os indivíduos em ações comuns.

O controle do imaginário social, da sua reprodução, difusão e manejo, assegura em graus variáveis uma real influência sobre os comportamentos e as atividades individuais e coletivas, permitindo obter os resultados práticos desejados, canalizar as energias e orientar as esperanças. (...) Os imaginários sociais operam ainda mais vigorosamente, talvez, na produção de visões futuras, designadamente na projeção das angústias e sonhos coletivos sobre o futuro ${ }^{9}$.

A arte, portanto, é um desses instrumentos de construção de imaginário social, que foi amplamente utilizada para legitimar o poder, constituindo-se em lugares de memória de acontecimentos que eram selecionados para ocupar as mentes e os corações da população. Como indicaram Esther Acevedo e Fausto Ramírez ${ }^{10}$, examinando o papel das imagens na construção cívica mexicana, a nação é criada mediante a representação e a celebração de seu passado, por meio da narrativa dos textos históricos, das imagens de pintura histórica, dos rituais cívicos celebrados nos "altares da pátria"onde a cidadania encontrava, naquele momento, a sua identidade coletiva. Com a consolidação do Estado Moderno, o imaginário nacionalista promoveu à comunidade um sistema de metáforas para se explicar e compreender o mundo. É fundamental, portanto, seguindo as orientações de Ulpiano Bezerra de Meneses ${ }^{11}$, perceber as telas não como objetos de investigação em si, mas vetores para a investigação de aspectos relevantes na organização, funcionamento e transformação de uma sociedade.

Meneses demonstra como a forma tem o poder de gerar significado e a arte deve servir de plataforma de articulação e observação da sociedade, já que o objeto da história é a sociedade, o seu funcionamento e as suas transformações. Dessa maneira, o que está se propondo é a análise da dimensão visual da sociedade. $O$ autor afirma que trabalhar historicamente com imagens obriga a percorrer o ciclo completo de sua produção, circulação e consumo. Tomando a imagem como um enunciado, deve-se situa-las em seus contextos situacionais. Ele indica também a importância de retraçar a biografia, carreira, a trajetória das imagens.

\footnotetext{
${ }^{9}$ Idem, p. 312.

${ }^{10}$ ACEVEDO, Esther; RAMÍREZ, Fausto. Preámbulo. In LOS PINCELES de la historia - La fabricación del estado, 1864-1910. Ciudad de Mexico: Banamex: Patronato del Museo Nacional de Arte, 2003, p. 18.

11 MENESES, Ulpiano T. Bezerra. Fontes visuais, cultura visual, história visual. Balanço provisório, propostas cautelares. Revista Brasileira de História, São Paulo, v. 23, n. 45, p. 11-36, 2003, p. 27.
} 
Para se realizar a história visual, Meneses indica três focos que merecem destaque para serem abordados nas pesquisas monográficas de quadros: o visual, que engloba a "iconosfera" e os sistemas de comunicação visual, os ambientes visuais, a produção/ circulação/ consumo/ ação dos recursos e produtos visuais; o visível, que diz respeito à esfera do poder, aos sistemas de controle, à "ditadura do olho", ao ver/ser visto e ao dar-se/ não dar-se a ver, aos objetos de observação e às prescrições sociais e culturais de ostentação e invisibilidade; a visão, os instrumentos e técnicas de observação, os papéis do observador, os modelos e modalidades do "olhar". Esses insumos permitem investigar a visualidade, concebida como uma variedade de discursos e práticas constituindo formas distintivas da experiência visual em circunstâncias históricas específicas ${ }^{12}$.

Meneses afirma ainda que as imagens não tem sentido por si próprias, já que o sentido é produzido na interação social, ao mobilizar determinados atributos para dar existência social a sentidos e valores e fazê-los atuar. É por isso que uma mesma imagem pode ser reciclada, assumir diversos papéis, ser ressemantizada. Sobre este aspecto, Baczko ${ }^{13}$, acrescenta que para garantir a dominação simbólica, é de grande importância controlar os meios de difusão dos imaginários sociais, que são os instrumentos de persuasão, pressão e inculcação de valores e crenças.

Para dar suporte às decisões que configurariam as soluções visuais relativas a episódios ou personagens de caráter considerados históricos, os artistas baseavam-se costumeiramente em documentos visuais e textuais. A base documental servia de fundamento para que os quadros fossem considerados uma representação do real, figurado em intenção realística ou de acordo com soluções que construíam uma visão decorosa, adequada do passado. Acevedo e Ramírez descrevem as exigências que deveriam ser seguidas pelos artistas:

Al pintor de historia se le exigía obedecer las reglas de la verosimilitud, tanto por lo que
mira a una elaboración laboriosa de los pormenores del cuadro (ambientación,
vestuario, accesorios), como, sobre todo, en lo tocante a la fidelidad a los recuentos
narrativos del hecho que se proponía representar. De allí la importancia de consultar
las mejores fuentes textuales y visuales, para la mejor compresión del asunto, ya la
solución de determinados problemas compositivos y de detalle. Es cierto que el artista
se permitía a veces algunas libertades, por requerimientos ya compositivos, ya

\footnotetext{
${ }^{12}$ Idem, p. 30-31.

${ }^{13}$ BACZKO, Bronislaw. Imaginário social. In ROMANO, Ruggiero (org.). Enciclopédia Einaudi,volume 5: Anthropos-Homem. Lisboa: Imprensa Nacional; Casa da Moeda, 1985, p. 313.
} 
expresivos; pero se arriesgaba a ser juzgado con dureza por la crítica, incluso por detalles que hoy parecen nimios ${ }^{14}$.

Dessa maneira, os quadros de pintura histórica foramrecorrentemente vistos como representações da "verdade" e foram absorvidos pelo imaginário coletivo da sociedade a que pertenciam. Quando musealizados, tornavam-se "janelas para o passado", cumprindo sua missão didática ao permitir a visualização do passado a milhares de cidadãos. Foram, e são, meios privilegiados para a materialização da célebre prédica de Eugène Viollet-le-Duc ${ }^{15}$ _"voir c'est savoir" - que presidiu grande parte dos processos de musealização da História no século XIX e parte do XX.

Atualmente, no entanto, esforços são empreendidos para desconstruir a ideia das telas serem fiéis à realidade e contemporâneas aos momentos retratados. Elas são, sim, documento de uma época, mas não são o registro da verdade. Como indicou Meneses, elas correspondem mais ao momento em que foram produzidas do que à cena retratada. Além disso, apesar da preocupação do artista em realizar uma pesquisa em fontes sobre o queria retratar, detendo-se em cada detalhe, o valor documental da pintura não reside na "precisão" histórica, já que ela é, antes de mais nada, representação, reelaboração plástica ${ }^{16}$. Assim, compreende-la historicamente é integrá-la às necessidadessimbólicas vividas pelo artista e sua sociedade, portanto, constitui-se como fonte preciosa de informações para reconstruir e entender o imaginário de sua época.

Com a generalização dos museus públicos no século XIX, a pintura histórica integrou decisivamente as experiências de construção de uma narrativa para as nações. O caso exemplar é, por certo, a Galerie des Batailles do Museu de História da França, aberto no Castelo de Versailles em 1837. O edifício havia sido a residência do rei Luís XIV e, como relatou Gerárd Sabatier ${ }^{17}$, com os Bourbon havia se tornado símbolos do poder real, constituindo o imaginário da monarquia. Thomas Gaehtgens ${ }^{18}$

\footnotetext{
${ }^{14}$ ACEVEDO, Esther; RAMíREZ, Fausto. Preámbulo. In LOS PINCELES de la historia - La fabricación del estado, 1864-1910. Ciudad de Mexico: Banamex: Patronato del Museo Nacional de Arte, 2003, p.25.

15 Viollet-le-Duc afirma que "le meilleur moyen de développer l'intelligence et de former le jugement, car on apprendainsi à voir, et voirc'est savoir" In VIOLLET-LE-DUC, Eugène Emmanuel, Histoired'undessinateur: commentonapprend à dessiner. Paris: Berger-Levrault, 1978, p. 302.

16 MENESES, Ulpiano T. Bezerra de (org.). Como explorar um museu histórico. São Paulo: Museu Paulista/USP, 1992, p. 23.

17 SABATIER, Gérard. Les lieux de pouvoir de la monarchie français eau temps des Bourbons, XVII ${ }^{\mathrm{e}}$ $X \mathrm{VIII}{ }^{\mathrm{e}}$ siècle. In BREFE, Ana Claudia (org). Pouvoirs: representer le pouvoir en France du MoyenÂge à nos jours. Paris: Somogy; Nantes: Musée du château des ducs de Bretagne, 2008, p.61-76

18 GAEHTGENS, THOMAS. Le musée historique de Versailles. In NORA, Pierre; AGERON, CharlesRobert. Les lieux des mémoire - La Nation. Gallimard, 1997, p. 144-145
} 
relata que, com a Revolução Francesa e a expulsão dos Bourbon, ficou decidido que o castelo deveria ser mantido como evidência da era feudal. Contudo, Luis Filipe, em 1833, decidiu transformá-lo em museu histórico, utilizando-o não apenas como monumento, mas como espaço para narrar toda a história da França, que incluía o Absolutismo, bem como o seu declínio e o início de uma nova era.

Segundo Manoel Luiz Salgado Guimarães ${ }^{19}$, o museu de Versailles foi 0 primeiro a de autodenominar "de história" e tinha por finalidade percorrer toda a história da França, sendo concebido como "o encontro de nossa história nacional". As suas galerias demonstravam a tradição de exibir o "exempla virtutis" ${ }^{20}$, assim, foram destacados os feitos gloriosos da França, que já estão anunciados na inscrição contida nos frontões de duas de suas galerias: "À toutes les gloires de La France". Para Thomas Gaehtgens ${ }^{21}$, o projeto de Louis-Philippe difere de todos os anteriores na medida em que procura provar que esses feitos gloriosos foram possíveis porque eram nacionais. O Museu Histórico apela para o sentimento da comunidade de cidadãos. E a galeria que mais claramente reflete esse objetivo foi a Galerie des Batailles, espaço monumental concebido no reinado de Louis-Philippe e materializado por meio da destruição de numerosos aposentos existentes no século XVIII. Foi projetada especialmente para abrigar uma narrativa visual sobre a história da pátria. Estão ali reunidos quadros históricos de dimensões gigantescas, representando batalhas desde a conquista romana, realizados por pintores como Horace Vernet, François Gérard, Eugène Delacroix e Auguste Couder. A série de pinturas e a própria Galeria foram um contraponto à também gigantesca Galeria dos Espelhos de Luís XIV, deslocando a compreensão da glória da França de uma derivação da majestade monárquica para uma cadeia de feitos em que o povo e seus chefes militares eram os agentes históricos.

Por meio da conversão de Versailles em museu histórico e da teatralização do passado presente na Galleriedes Batailles, o Estado francês tornou-se o guardião da memória nacional, zelando pela fixação de modelos de valores e comportamentos que passavam a ser considerados parâmetros para a Nação. Aí reside a importância da iconografia, uma vez que museus inspirados em Versailles utilizaram as grandes telas

\footnotetext{
${ }^{19}$ GUIMARÃES, Manoel Luiz Salgado. Vendo o passado: representação e escrita da história. Anais do Museu Paulista: História e Cultura Material, São Paulo, v. 15, n. 2, p. 11-30, jul-dez 2007, p. 26.

20 Segundo Thomas Gaehtgens, "L'histoire elle-même de l'aménagement de galeries dans d'autres châteaux français témoigne d'une tradition qui consistait à exhlierces exempla virtutis aux yeux du souverain et de lacour". Ver em GAEHTGENS, THOMAS. Le musée historique de Versailles. In NORA, Pierre; AGERON, Charles-Robert. Les lieux des mémoire - La Nation. Gallimard, p. 143-168, 1997, p. 149.

21 GAEHTGENS, Thomas. Le musée historique de Versailles. In NORA, Pierre; AGERON, CharlesRobert. Les lieux des mémoire - La Nation. Gallimard, 1997, p. 148-150.
} 
históricas para exercerem as suas funções celebrativas e pedagógicas. Por meio delas, evocava-se o passado, presentificando-o.

Se o conjunto de telas de batalhas de Versailles jamais foi replicado em extensão ou em sua espacialidade nos museus ocidentais, a consagração da pintura histórica como narrativa nacional generalizou-se na Europa, incluindo as Américas. Como indicou Saúl Juaréz ${ }^{22}$, o período de 1864 a 1910, foi uma época de grandes transformações no México, de mudanças que favoreceram o estabelecimento e a consolidação de um projeto de país, a revisão da história nacional e a releitura do passado. A partir de então, os pintores "tomaron lienzos y pinceles para escribir, con vigorosos y firmes trazos, los episodios fundacionales de México, aquellos momentos en los que la Nación comenzó a gestarse aun sin que sus participantes tuvieron conciencia de ello" ${ }^{23}$. Estas teriam sido a base para a construção dos "altares da pátria", que sustentaram a identidade mexicana. Maria Ligia Coelho Prado ${ }^{24}$ chama a atenção para os quadros produzidos no Cone Sul - Uruguai, Chile e Argentina - e como alguns artistas, como Juan Manuel Blanes e Pedro Subercaseaux, ultrapassaram as fronteiras de seus territórios, para produzir quadros para os países vizinhos. Isso ocorreu, sobretudo, na passagem do século XIX para o XX, quando se construíam as narrativas nacionais e também nas grandes comemorações, como os centenários de independências.

No Brasil, como relataram Tadeu Chiarelli ${ }^{25}$, Valéria Salgueiro ${ }^{26}$, Luciano Migliaccio ${ }^{27}$, entre outros, a formação de um sistema artístico oficial se deu graças à elevação do Brasil à condição de reino e o novo status do Rio de Janeiro, que se tornou capital. De maneira que a constituição de uma nova capital não poderia ocorrer sem a formação de uma classe de artistas e artesãos comprometidos com a simbolização da nova ordem. Em 1816, foi criada a Academia Imperial de Belas Artes, que possibilitou a consolidação da dita "arte acadêmica", nitidamente vinculada à tradição europeia.

\footnotetext{
22 JUARÉZ, Saul. Presentación. In LOS PINCELES de la historia - La fabricación del estado, 1864-1910. Ciudad de Mexico: Banamex: Patronato del Museo Nacional de Arte, 2003, p. 10. 
Durante o Império, sobretudo no segundo reinado, o mundo artístico estava centrado no Rio de Janeiro e no patrocínio imperial. A pintura acadêmica mantinha uma relação muito estreita com o projeto pessoal do próprio imperador, D. Pedro II. Isso se intensificou com a chamada "reforma pedreira", realizada por Manuel Araújo Porto-Alegre, em 1855, já que a AIBA passou a estar diretamente a serviço da construção do imaginário do império. O universo iconográfico estava atrelado à figura de D. Pedro II, e os quadro produzidos mesclavam símbolos e objetos da casa real com elementos da paisagem local. Após 1870, ganharam destaque também as cenas de batalhas, como a Batalha do Avaí, realizada por Pedro Américo e a Batalha de Guararapes, de Victor Meirelles, embora, frise-se, jamais tenham sido musealizados no século XIX. Outro quadro de grande destaque deste período foi Independência ou Morte de Pedro Américo, encomendado para figurar no palácio projetado por Tommaso Bezzi na cidade de São Paulo, monumento que estava sendo erigido no bairro do Ipiranga em homenagem à Independência do Brasil e que seria convertido em museu aberto ao público em 1895. Com o advento da República, o Rio de Janeiro perdeu o monopólio de criação da arte oficial, já que o regime federalista fez com que governos estaduais se empenhassem na iniciativa de culto aos heróis e à história regional. O passado passou a ser alvo dos pincéis dos artistas em estados como São Paulo, Rio Grande do Sul ou Pará, tendo um evidente sentido pedagógico: ensinar a população, na sua maioria analfabeta, os grandes eventos da história regional e local que, naquele momento, estavam sendo forjados como evidência do protagonismo desses estados ou de suas capitais nos destinos da nação.

A implantação de monumentos escultóricos públicos na cidade do Rio de Janeiro durante os primeiros anos da República integrou a tentativa de se tornar a capital um protagonista simbólico do país, indicando que a arte era parte fundamental da legitimação de novos agentes políticos durante as disputas e reequilíbrios de poder que caracterizaram a Primeira República, como indicou José Murilo de Carvalho ${ }^{28}$.

Durante a Primeira República, São Paulo inseriu-se na órbita do poder político dominante, especialmente a partir da presidência de Prudente de Moraes. O estado, economicamente favorecido pela produção de café, principal produto de exportação brasileiro, passou a investir na ampliação do seu poder político e também na sua projeção cultural, especialmente artística e literária, que durante todo o Império havia estado ofuscada pelo brilho da Corte. Urgia também, como indica a criação do Instituto Histórico e Geográfico de São Paulo em 1894, gerar narrativas sobre o passado que

\footnotetext{
${ }^{28}$ CARVALHO, José Murilo de. A formação das almas. O imaginário da República no Brasil. São Paulo:
} Companhia das Letras, 2009, p. 10. 
realçassem o peso dos paulistas nas trajetórias da nação. É célebre a passagem da apresentação do primeiro número da revista do referido instituto - $A$ história de $S$. Paulo é a própria história do Brasi ${ }^{29}$ - em que está expressa de maneira cristalina uma ambição de liderar não apenas o presente, mas alicerçar tal posição do comando como uma decorrência do passado.

A demolição generalizada da rústica cidade de taipa, que caía sob as reformas urbanas da gestão de Antonio Prado ${ }^{30}$ realizadas na capital paulista a partir de 1899 , dispensara o testemunho material de tempos de muito menos fortuna do que o do café. Mas, se os documentos materiais do passado colonial e imperial eram dispensáveis, senão incômodos por sua modéstia, a historiografia e as obras de arte voltadas ao passado dos primeiros povoadores, à missão evangelizadora e civilizadora dos jesuítas e ao sertanismo tiveram um papel fundamental de construir uma história dos quais os paulistas - e suas elites dirigentes - podiam se orgulhar.

Nesse contexto de constituição de "lugares de memória" capazes de construir uma memória coletiva e oficial, muitas pinturas históricas foram encomendadas e compradas pelo governo estadual paulista. Dentre elas, esteve a tela Fundação de São Paulo, concluída por Oscar Pereira da Silva em 1907, que foi de fundamental importância para a construção do imaginário nacional, paulista e paulistano, em especial no que diz respeito ao que teria sido o início da experiência de constituir os primeiros espaços urbanos no Brasil.

A tela Fundação de São Paulo, hoje pertence ao Museu Paulista da USP, encontra-se, desde 2007, integrada a uma exposição de longa-duração denominada Imagens Recriam a História, voltada à problematização das telas históricas como representações, compreendidas necessariamente a partir de sua concepção e apropriação social ${ }^{31}$. Inserida na sala Imaginar o início, dedicada às obras de arte que têm por tema momentos vinculados ao início da conquista portuguesa, essa tela está ladeada por outros dois quadros de grande formato - Fundação de São Vicente, concluída por Benedito Calixto em 1900, e Desembarque de Pedro Álvares Cabral em Porto Seguro em 1500, concluída por Oscar Pereira da Silva em 1900. Tal conjunto,

\footnotetext{
${ }^{29}$ Revista do Instituto Histórico e Geográfico de São Paulo, São Paulo, v. 1, 1895, p. 3.

${ }^{30}$ Sobre as reformas urbanas realizadas durante a gestão de Antonio Prado no município de São Paulo, ver HOMEM, Maria Cecília Naclério. Antonio Prado, prefeito da cidade de São Paulo: 1889-1910. In: V Seminário da Cidade e do Urbanismo, 1998, Campinas. Cidades: temporalidades em confronto. Campinas: Pontifícia Universidade Católica de Campinas, 1998.

${ }^{31}$ MARINS, Paulo César Garcez. Obras de arte em um museu de história: desafios metodológicos na documentação de acervo do Museu Paulista da USP. In: I Seminário Internacional Arquivos de Museus e Pesquisa, 2009 (MAGALHÃES, Ana Gonçalves, org.). São Paulo: Museu de Arte Contemporânea da USP, 2010, p. 72-82.
} 
hoje reunido em uma sala, não o foi senão na segunda metade do século $X X$, pelo que não podem ser consideradas como um conjunto criado sob uma intenção cênica inspirada na Gallerie des Batailles. São, entretanto, um testemunho dos mais importantes do país no que tange à produção de telas históricas de grande formato, criadas no caudal de obras precedentes, seja sob o Império, sejam aquelas criadas na França ou na Itália no século XIX.

A tela Fundação de São Paulo foi objeto de inúmeras reproduções em diferentes suportes de objetos integrados à vida social, tais como vitrais, selos, postais, cartões telefônicos, porcelanas, bandejas, etc. Tais suportes permitiram a imensa difusão de seu discurso visual, cujo fulcro principal associava a origem da cidade de São Paulo à cristianização, e o papel dessa no ordenamento do contato entre europeus e indígenas naquela nascente missão jesuítica que daria origem à vila e à cidade. A tela é compreendida, assim, como um meio fundamental para a criação de um imaginário social sobre a origem urbana de São Paulo.

Malgrado essa importância da tela Fundação de São Paulo como referência visual frequente na evocação do início da trajetória da capital, a exposição também trouxe à tona uma imensa carência de estudos sobre essa obra de Oscar Pereira da Silva, seja no que tange a sua datação, suas primeiras exposições ou mesmo sobre o primeiro destino preciso da obra nas coleções públicas estaduais.

Atento à sinalização conceitual indicada pela exposição Imagens recriam a História, esta dissertação se propõe a recompor o circuito social da tela ${ }^{32}$, a fim de compreender o processo de criação da obra, as interlocuções intelectuais, políticas e religiosas que estiveram associadas à sua criação, bem como seu processo de musealização e difusão por meio de apropriações até o IV Centenário de São Paulo, momento em que situa o clímax de sua reprodução.

Os poucos dados disponíveis sobre Fundação de São Paulo indicavam que a obra havia sido encomendada pelo Governo do Estado ${ }^{33}$ e que havia sido concluída em $1909^{34}$. A pesquisa, no entanto, reviu as escassas certezas que se tinham sobre a

\footnotetext{
32 MENESES, Ulpiano T. Bezerra. Fontes visuais, cultura visual, história visual. Balanço provisório, propostas cautelares. Revista Brasileira de História, São Paulo, v. 23, n. 45, p. 11-36, 2003.

${ }^{33}$ Como foi dito por Ruth Tarasantchi, "Fundação de São Paulo é também um quadro de grandes dimensões (185 x $340 \mathrm{~cm}$ ), feito por encomenda do Governo do Estado". TARASANTCHI, Ruth Sprung, Oscar Pereira da Silva. São Paulo: Empresa das Artes, 2006, p. 81.

${ }^{34}$ A informação sobre a data aparece não apenas na exposição Imagens recriam a história, como nos livros e enciclopédias que fazem referência ao quadro, como é possível verificar na enciclopédia eletrônica Itaú Cultural:

http://www.itaucultural.org.br/aplicexternas/enciclopedia ic/index.cfm?fuseaction=artistas obras\&acao=m ais\&inicio=17\&cont acao=3\&cd verbete=2952. Acesso em 30/09/2012.
} 
tela, pois conseguiu demonstrar, como se verá à frente, que mesmo essas informações basilares estavam equivocadas. Entretanto, muito mais do que uma revisão de dados factuais, esta dissertação pretende tomar essa tela capital como obra de arte como representação do espaço urbano, da ordem social vinculada à cidade, almejando-se compreender as múltiplas percepções que ela ganhou ao longo de sua inserção na vida social e como configurou um imaginário sobre as relações entre o contato inter-étnico e a experiência urbana paulistana.

A cidade e sua representação são, assim, compreendidas como um binômio cuja compreensão é um dos desafios centrais desta dissertação. "Lugar de memória" por excelência no que tange à construção de uma memória coletiva, instrumento de consagração da fé como eixo de civilização e da própria história dos paulistanos, paulistas e também dos brasileiros, Fundação de São Paulo é tomada aqui como documento para a compreensão do artista, da sociedade e da cidade que a engendrou como símbolo e ícone. A volta ao passado remoto, do qual não restavam memórias correntes de monta, é, portanto, compreendida como um esforço de agentes sociais em oferecer uma interpretação coletiva para uma história do contato sempre renovada, que ofereça sentidos para os novos milhares de contatos em marcha na então multiétnica capital paulista, ou nas fronteiras do café que novamente confrontavam colonizadores e populações indígenas.

O primeiro capítulo dedica-se à gênese da obra. Analisa-se a carreira do artista em São Paulo e o que haveria motivado a realização do quadro. Foram também observadas as fontes que serviram de respaldo para a elaboração da tela e que pretendiam assegurar o vínculo com a realidade do que se acreditava ter ocorrido no passado, que seguiam as propostas dos historiadores e intelectuais e que, naquele momento, empenhavam-se na construção de um passado glorioso para São Paulo. Ademais, para que se forjasse uma obra digna de representar um evento tão digno quanto o ato de origem de São Paulo, era importante estabelecer um equilíbrio entre sustentação em documentos considerados autênticos, vínculo ambicionado pelos historiadores dos institutos históricos, e entre imaginação e idealização baseadas em convenções pictóricas. A representação, portanto, precisava se adequar ao evento cuja mensagem se queria perpetuar na pintura, que deveria seguir modelos de composição oficializados pelas academias ${ }^{35}$. Por isso, a composição formal da tela é

\footnotetext{
${ }^{35}$ MARINS, Paulo César Garcez. Nas matas com pose de reis: a representação de bandeirantes e a tradição da retratística monárquica européia. Revista do Instituto de Estudos Brasileiros, São Paulo, v. 44, p. 77-104, 2007, p. 92-97.
} 
também uma perspectiva importante explorada no capítulo, bem como os possíveis diálogos com quadros que serviram de referência para a sua composição.

O segundo capítulo analisa o impacto e as conseqüências das escolhas de formais de Oscar Pereira da Silva na trajetória social da tela. Para tanto, foram resgatadas as críticas que a obra recebeu e se reconstituiu o difícil processo de aquisição, para o qual concorreram a campanha empreendida pela imprensa e o imenso esforço do artista em alcançar uma inserção nos meios intelectuais e políticos paulistanos que pudessem ajuda-lo na venda do quadro para o Estado. A tela é também relacionada às aquisições públicas de obras de arte do início do século XX, momento justamente de grandes encomendas empreendidas pelo Museu Paulista, bem como do surgimento da Pinacoteca, para a qual a tela foi destinada em 1909. O capítulo também procura compreender as diferenças entre essas instituições, bem como as atribuições de valor histórico ou valor artístico que norteavam a destinação de obras de arte para esses museus, âmbito no qual está inserida a tela de Oscar Pereira da Silva.

O terceiro capítulo traça o processo e os motivos que transformaram o status da tela quando a mesma foi transferida da Pinacoteca do Estado para o Museu Paulista. Ao entrar nessa instituição, Fundação de São Paulo era francamente contrastiva ao projeto de exposição elaborado por Affonso de E. Taunay em 1922, por celebrar enfaticamente os jesuítas e não os colonizadores como protagonistas de São Paulo. Contudo, em 1954, a obra tornou-se uma das principais referências visuais da fundação da cidade durante o IV Centenário de São Paulo, sobretudo à luz de uma corrente historiográfica católica que ganhava força ao longo da primeira metade do século XX, quando começou a ser difundida uma visão que São Paulo teria uma dívida sagrada com a Companhia de Jesus. Tal discurso tomou corpo entre os setores mais tradicionalistas das elites paulistanas e serviu de mote, por exemplo, para a reconstrução do Pátio do Colégio. Foi nesse contexto que a obra de Oscar Pereira da Silva foi intensamente reproduzida e difundida, passando a desempenhar um papel fundamental na formulação de um imaginário urbano na cidade de São Paulo e no próprio Brasil. 


\title{
CAPÍTULO 1
}

\section{Fundando a urbe: reelaboração de um modelo pictórico}

\author{
QUADRO HISTORICO \\ O pintor Oscar Pereira da Silva trabalha atualmente num quadro histórico e que se \\ inspira no passado paulista. \\ Para o respectivo esboço o distinto artista tem procurado investigar antiguidades e \\ tradições coloniais. \\ Desejando obter conhecimentos mais aprofundados, Oscar Pereira da Silva tem \\ procurado arquivos, esteve no Museu do Estado e ainda ontem consultou várias \\ obras na biblioteca da Escola Normal' ${ }^{1}$.
}

Com essa notícia, teve início a longa trajetória do quadro Fundação de São Paulo, de Oscar Pereira da Silva, nos mais importantes órgãos da imprensa paulistana ${ }^{2}$.

Embora sequer mencionada diretamente, pode-se aferir que fosse ela o motivo de suas investigações, e dessa notícia, visto ser essa a única tela de tema histórico documentada realizada nesse período da carreira do artista fluminense instalado na capital do café. A notícia também não precisa um fato que, como se verá, é dado importante para compreender o papel dessa tela na carreira de Oscar Pereira da Silva: a pesquisa que realizava não era para uma encomenda, mas para uma aposta incerta, e de grandes dimensões, do artista migrante em obter mais um degrau em sua escalada profissional. Fundação de São Paulo é uma "pintura histórica", gênero mais importante no sistema acadêmico e por meio do qual Pereira da Silva já lograra uma vitória anterior em São Paulo, quando Desembarque de Pedro Álvares Cabral em Porto Seguro em 1500 fora comprada para integrar o acervo do Museu Paulista.

A nova tela que começava a ser planejada naqueles inícios de 1907, justamente no mês em que se comemorava a fundação de São Paulo pelos jesuítas em 25 de janeiro 1554, tinha também uma outra pretensão, devido a seu tema central. A pintura foi a primeira representação de grandes dimensões, e de incontestável impacto visual, a oferecer uma "visão" do início da cidade, quando ainda mera missão jesuítica. Fundação de São Paulo, foi inspirada, como será demonstrado, na Primeira

\footnotetext{
${ }^{1}$ Correio Paulistano, 22 de janeiro de 1907.

${ }^{2}$ A pesquisa não conseguiu identificar noticias mais antigas do que esta sobre a tela. Infere-se que quando o articulista fala em "quadro histórico" esteja se referindo à Fundação de São Paulo, pois é a única pintura histórica que Oscar Pereira da Silva faz no período de 1905 a 1913.
} 
missa no Brasil, de seu mestre Victor Meirelles, transpondo e reelaborando para o ambiente paulista a representação da fundação nacional - aqui também cívica e citadina - por meio do contato inter-étnico, mediado e presidido pela fé cristã.

A pesquisa a que Oscar Pereira da Silva se dedicava naquele janeiro de 1907 procurava, assim, obter referências iconográficas e documentais que sustentassem uma representação apropriada do passado mais remoto de São Paulo, que nascia sob o império da cruz.Suas escolhas acabaram, também aqui, por configurarem uma tomada de partido, incerta e arriscada, pelo artista forasteiro diante do debate historiográfico na florescente cidade do café.

\section{Um artista fluminense na capital do café}

Oscar Pereira da Silva era um artista migrado para São Paulo, mais um forasteiro em meio aos milhares que ali estavam estabelecidos desde fins do século XIX. Mas ali chegara, por certo, com um expressivo capital cultural que o distinguia de seus pares adventícios.Nascido na cidade fluminense de São Fidélis, em 27 de Agosto de $1867^{3}$, eleingressou na carreira artística em 1882, ao se tornar aluno da Academia Imperial de Belas Artes, instituição que monopolizou o ensino e a produção artística do Império ${ }^{4}$. Teve como professores Zeferino da Costa, Victor Meirelles, Chaves Pinheiro e José Maria de Medeiros. Ainda como artista principiante, Pereira da Silva foi citado numa crítica feita por Gonzaga Duque ${ }^{5}$ no periódico $A$ Semana:

\footnotetext{
${ }^{3}$ Tarasantchi afirma, baseado em Laudelino Freire, que ele haveria nascido em maio de 1865: "Oscar Pereira da Silva nasceu em São Fidelis, no estado do Rio de Janeiro, a 20 de maio de 1865. Nos apontamentos feitos por Afonso Freitas sobre o artista, com o qual conviveu, ele insiste ser esta a data correta ,e não 27 de agosto, como aparece no livro Um século de pintura, de Laudelino Freire, e em outras biografias." In TARASANTCHI, Ruth Sprung. Oscar Pereira da Silva. São Paulo: Empresa das Artes, 2006, p. 23. Já a enciclopédia latú Cultural afirma que ele teria nascido em 1967. A pesquisa para esta dissertação conseguiu localizar o documento de identidade do artista, pertencente ao acervo do Instituto Histórico e Geográfico de São Paulo e que foi recentemente transferida para o Arquivo do Estado; ele aponta seu nascimento como 27 de agosto de 1867.

${ }^{4}$ Em 1816, foi fundada a Academia Imperial de Belas Artes no Rio de Janeiro. Segundo Tadeu Chiarelli, se antes a formação do artista era feita de maneira anônima, ele era confundido com um artesão, a partir da criação da Academia, era de se esperar que o artista começasse a ser pensado como um profissional ao qual estaria reservada uma formação erudita, propícia a captá-lo no sentido de fazê-lo interagir no processo de constituição de uma cultura visual superior. Ver CHIARELLI, Tadeu. GonzagaDuque: a moldura e o quadro da arte brasileira. In: DUQUE ESTRADA, Luis Gonzaga. A arte brasileira. Campinas, SP: Mercado de Letras, 1995.

${ }^{5} \mathrm{O}$ artigo é assinado por "Alfredo Palheta", pseudônimo utilizado por Gonzaga Duque na coluna de crítica de arte que realizava para a revista $A$ semana. Apud Enciclopédia Itaú Cultural de artes visuais,
}

http://www.itaucultural.org.br/aplicexternas/enciclopedia ic/index.cfm?fuseaction=artistas biografia\&cd ve rbete $=1957 \&$ Ist palavras $=\&$ cd idioma $=28555 \&$ cd item $=1$. Acesso em 20/11/2012 
Pereira da Silva começa agora a dar os primeiros passos no vastíssimo templo da arte; é bisonho adepto dessa sublime religião do belo professada por Pedro Américo, Aurélio de Figueiredo, Décio, Belmiro e Vítor Meireles. Aos que começam com talento e vontade não se deve descoroçoar.

Continue o jovem artista a trabalhar resolutamente, a pintar, guiado por sua inspiração, por seu sentimento artístico, que terá a recompensa desses esforços, a paga desse talento aproveitado.

(...)

Assim pois, dizemos-Ihe: a sua obra, para um principiante, é muito boa, é uma esplêndida prova de talento que vai evoluindo, e por esse motivo merece as nossas palmas. Mas, continue a estudar, a estudar muito, para não desmentir a esperança que esta obra lançou em nosso espírito, e para vencer a grande distância que Ihe falta para ser um verdadeiro artista ${ }^{6}$.

Como se pode observar por esse comentário, desde o início de sua carreira Oscar Pereira da Silva ensejou grandes expectativas, por seu talento e aptidão à arte. Seguindo orientações do vaticínio proposto pelo articulista, ele continuou a estudar a fim de se tornar um "verdadeiro artista". Para tanto, inscreveu-se em $1887^{7}$ no concurso para o "Prêmio de Viagem" da Academia Imperial de Belas Artes, que visava o aprimoramento na Europa "dos melhores alunos do estabelecimento" ${ }^{\text {. Vencer o }}$ concurso era considerado indispensável ao progresso artístico brasileiro, já que o período de estudos em Paris ou Roma era tido como indispensável para o aperfeiçoamento do que se aprendia no Rio de Janeiro, sendo o mais alto prêmio que um aluno da AIBA podia almejar. Assim, a estadia nas capitais européias da arte distinguia definitivamente os pensionistas, trazendo o reconhecimento e a admiração do público ${ }^{9}$.

\footnotetext{
${ }^{6}$ A Semana, 25 de julho de 1885.

${ }^{7}$ Após um intervalo de nove anos, em1887, foram abertas as inscrições para o concurso que oferecia duas vagas, para as quais oito candidatos se apresentaram: sete pintores de história - Antonio Raphael Pinto Bandeira, Francisco Hilarião Teixeira da Silva, Manoel Teixeira da Rocha, Belmiro Barbosa d'Almeida, Oscar Pereira da Silva, Sebastião Vieira Fernandes e Eduardo Sá - e um arquiteto - João Ludovico Maria Berma. Ver CAVALCANTI, Ana Maria Tavares. Belmiro de Almeida (1858-1935), Oscar Pereira da Silva (1867-1939) e o polêmico concurso para Prêmio de Viagem de 1887. In: XXVI Colóquio do Comitê Brasileiro de História da Arte, 2007, São Paulo. Anais do XXVI Colóquio do Comitê Brasileiro de História da Arte. Belo Horizonte: Editora C/Arte, 2007, p. 266-274.
}

${ }^{8}$ CHIARELLI, Tadeu. Gonzaga-Duque: a moldura e o quadro da arte brasileira. In: DUQUE ESTRADA, Luis Gonzaga. A arte brasileira. Campinas, SP: Mercado de Letras, 1995, p. 15.

9 CAVALCANTI, Ana Maria Tavares. Belmiro de Almeida (1858-1935), Oscar Pereira da Silva (18671939) e o polêmico concurso para Prêmio de Viagem de 1887. In: XXVI Colóquio do Comitê Brasileiro de História da Arte, 2007, São Paulo. Anais do XXVI Colóquio do Comitê Brasileiro de História da Arte. Belo Horizonte: Editora C/Arte, 2007, p. 266-274. 
Oscar Pereira da Silva concorreu ao prêmio com a tela "Flagelação de Cristo"10, cuja composição foi inspirada em um quadro de mesmo título de Victor Meirelles ${ }^{11}$. Os professores da comissão valorizaram a correção do desenho e o respeito às convenções, qualidades essas que garantiram o prêmio a Pereira da Silva. A viagem para Paris teve, no entanto, de ser adiada por quase três anos, pois assim que o resultado foi divulgado, uma polêmica se instalou entre os professores da Academia, já que Rodolpho Bernardelli e João Zeferino da Costa, ao contrário dos demais membros do júri, eram a favor de Belmiro de Almeida ${ }^{12}$. Apesar da confusão, Oscar Pereira da Silva foi enviado a Paris, onde teve a oportunidade de estudar com os pintores Léon Bonnat e Jean-Léon Gérôme.

Em 1896, o artista retornou ao Brasil e, após realizar uma exposição no Rio de Janeiro $^{13}$, transferiu-se para São Paulo, cidade que vinha sendo transformada rapidamente por conta da riqueza advinda da cafeicultura paulista e da chegada massiva de imigrantes. Desde a segunda metade do século XIX, o café era o principal produto de exportação brasileira e, com o declínio da produtividade das fazendas cafeicultoras no Vale do Paraíba, houve uma grande elevação da produção no Oeste Paulista, que converteu essa região numa das áreas mais dinâmicas do Brasil. Com o advento da República, as elites paulistas ligadas ao PRP e ao Oeste Paulista passaram a dotar a capital de melhoramentos capazes de dignificá-la, visto que desde 1900 o censo nacional passou a indicá-la como a segunda maior cidade do país ${ }^{14}$, superando Recife, Salvador e Porto Alegre ${ }^{15}$.

\footnotetext{
${ }^{10}$ Oscar Pereira da Silva. Flagelação de Cristo, óleo sobre tela, 117 x 89,5 cm, 1887, acervo do Museu D. João VI da Escola de Belas Artes da UFRJ, Rio de Janeiro.

11 Victor Meirelles, Flagelação de Cristo, óleo sobre tela, 150,9 x 115x4 cm, 1856, acervo do Museu Nacional de Belas Artes, Rio de Janeiro. "Não é se estranhar que Oscar Pereira da Silva, no concurso de 1887, tenha adotado a composição de Victor Meirelles. Afinal, esta era a prática da Academia. Os alunos apreendiam através das cópias de modelos apresentados como normas de excelência e bom gosto". CAVALCANTI, Ana Maria Tavares . Belmiro de Almeida (1858-1935), Oscar Pereira da Silva (1867-1939) e o polêmico concurso para Prêmio de Viagem de 1887. In: XXVI Colóquio do Comitê Brasileiro de História da Arte, 2007, São Paulo. Anais do XXVI Colóquio do Comitê Brasileiro de História da Arte. Belo Horizonte : Editora C/Arte, 2007. v. 1. p. 271.

${ }^{12}$ Sobre o polêmico concurso de 1887 ver CAVALCANTI, Ana Maria Tavares.. Belmiro de Almeida (18581935), Oscar Pereira da Silva (1867-1939) e o polêmico concurso para Prêmio de Viagem de 1887. In: XXVI Colóquio do Comitê Brasileiro de História da Arte, 2007, São Paulo. Anais do XXVI Colóquio do Comitê Brasileiro de História da Arte. Belo Horizonte : Editora C/Arte, 2007. v. 1. p. 266-274.

${ }^{13}$ No Rio de Janeiro, realiza uma exposição individual no salão da Escola Nacional de Belas Artes, na qual são apresentados 33 trabalhos feitos na Europa. Segundo Ana Paula Nascimento, a mostra foi mal recebida pela crítica. NASCIMENTO, Ana Paula. Espaços e a representação de uma nova cidade: São Paulo (1895-1929.).Tese (doutorado) - Faculdade de Arquitetura e Urbanismo, Universidade de São Paulo, São Paulo, 2009, p. 368-369.

${ }^{14}$ Segundo Paulo César Garcez Marins, o censo de 1872 indicou que a cidade de São Paulo contava com 31.385 habitantes. Em 1890, o número aumentou pata 64.943 habitantes, o que representou um crescimento de 106,9\%. Em 1900, o total de habitantes era 239.820 habitantes, ou seja, houve crescimento de $269,3 \%$. Nesse período, a capital paulista ficava atrás apenas do Rio de Janeiro, capital federal, que contava com 811.443 habitantes, com crescimento de $55.2 \%$ em relação ao período anterior.
} 
Pode-se dizer, portanto, que na passagem do século XIX para o XX, São Paulo transformou-se em outra cidade - com outras funções, outros habitantes e outros espaços.A riqueza do café favoreceu a adoção de novas formas de moradia urbana e interferiu também nos padrões de construção da cidade. Ela subsidiou o desenvolvimento econômico, acelerando o incremento das importações e do comércio interno, gerando a abertura de bancos, grandes e pequenas firmas comerciais, lojas de artigos variados, manufaturas e algumas fábricas têxteis. Com isso, ampliaram-se as oportunidades de ascensão social e houve uma transformação nos hábitos de consumo de parcelas significativas da sociedade urbana $^{16}$.

A atuação de determinados setores sociais privilegiados pela concentração de renda e de consumo foi primordial também para o desenvolvimento das atividades artísticas em São Paulo. Mirian Rossi demonstra que houve aumento expressivo no número de exposições ${ }^{17}$ que ocorreram nas primeiras décadas do século $X X$ e que contavam com grande presença do público paulista ${ }^{18}$. A autora afirma que o meio artístico paulistano desfrutava de uma condição privilegiada no cenário nacional, à

MARINS, Paulo César Garcez. Tensões sociais da gestão da metrópole. In CAMPOS, Candido Malta; GAMA, Maria Lucia Helena; SACCHETTA, Vladmir (orgs.). São Paulo, metrópole em trânsito: percursos urbanos e culturais. São Paulo: Editora Senac, 2004, p. 62.

15 SEGAWA, Hugo. São Paulo, veios e fluxos: 1872-1954. História da Cidade de São Paulo: a cidade na primeira metade do século XX (1890-1954) Org. Paula Porta. São Paulo: Paz e Terra, 2004, p. 21. MARINS, Paulo César Garcez. Tensões sociais da gestão da metrópole. In CAMPOS, Candido Malta; GAMA, Maria Lucia Helena; SACCHETTA, Vladmir (orgs.). São Paulo, metrópole em trânsito: percursos urbanos e culturais. São Paulo: Editora Senac, 2004, p. 62.

${ }^{16}$ SEGAWA, Hugo. São Paulo, veios e fluxos: 1872-1954. História da Cidade de São Paulo: a cidade na primeira metade do século XX (1890-1954) Org. Paula Porta. São Paulo: Paz e Terra, 2004. E BARBUY, Heloisa. A cidade-exposição: comércio e cosmopolitismo em São Paulo, 1860-1914.São Paulo: Edusp, 2006

17 Mirian Rossi procura desconstruir a ideia que São Paulo era uma cidade de parcas exposições e expectadores. Ela contradiz Aracy Amaral, que afirma que antes de 1920 havia poucas mostras na capital e que estas estavam diluídas em um ambiente indiferente e totalmente desinteressado pela renovação artística. Mirian Rossi demonstra que o número de exposições realizadas em São Paulo seguiu uma trajetória ascendente. De 1890 a 1900 ocorreram 9 exposições nacionais e 3 estrangeiras, entre individuais e coletivas, de 1900 a 1910 este número subiu para 37 e 28 respectivamente. O maior aumento ocorreu no período de 1910 a 1920, quando foram realizadas 131 exposições nacionais e 102 estrangeiras. Ver ROSSI, Mirian Silva. Organização do campo artístico paulistano 1890-1920. Dissertação (Mestrado) - Faculdade de Filosofia, Letras e Ciências Sociais, Universidade de São Paulo, São Paulo, 2001, p. 34-37.

${ }^{18}$ Mirian Rossi demonstra que o número de visitantes das exposições artísticas era significativo. Para tanto, apresenta alguns dados para exemplificar seu argumento. Ela afirma que a exposição de Parreiras realizada em 1904 recebeu um total de 8.022 visitantes durantes os dez dias que esteve aberta à visitação, número que correspondia a $3 \%$ da população local. Na média, a mostra recebeu por dia recebeu $0,3 \%$ da população. No ano seguinte, a exposição de Antonio Ferrigno teve 1.123 pessoas em um único dia, o que correspondia a $0,4 \%$ da população. Para demonstrar que esses números são relevantes, a autora compara a visitação com exposições de grande sucesso realizadas recentemente e que foram recordistas de público no Brasil, como a Exposição de Claude Monet, realizada no MASP em 1997, que recebeu em média 5.786 visitantes por dia, o que correspondia a $0,05 \%$ da população. A Mostra do Redescobrimento, realizada no Parque do Ibirapuera em 2000 recebeu 13.553 visitantes, o que corresponde a $0,05 \%$ da população.Ver ROSSI, Mirian Silva. Circulação e mediação da obra de arte na Belle Époque paulistana. Anais do Museu Paulista: História e Cultura Material, São Paulo, v. 6/7. p. 83119 (1998-1999). Editado em 2003, p. 85. 
frente da própria capital federal, já que havia um movimento crescente de exposições com considerável concorrência e pleno êxito financeiro. Chamada por Sarah Bernardt de "capital artística do Brasil"19, Rossi afirma que São Paulo gozava de uma relativa primazia no circuito das artes, que era reconhecida inclusive fora do estado, e conclui que:

em São Paulo havia condições favoráveis para a instalação de exposições, por isso atraía artistas de outros Estados, inclusive do Rio de Janeiro, que eram unânimes em dizer que em São Paulo "vendia-se mais"20.

A Oscar Pereira da Silva, pintor migrado, era imprescindível se adaptar aos novos contextos, a fim de garantir o sucesso de sua carreira, de modo a aproveitar da condição privilegiada que o meio artístico paulistano desfrutava no cenário nacional. Ainda em 1896, ano de sua chegada em São Paulo, ele começou a lecionar no Liceu de Artes e Ofícios na vaga liberada por Pedro Alexandrino, que partira para estudos na Europa como pensionista do governo paulista ${ }^{21}$. Tal inserção demonstra ter havido um rápido reconhecimento de seu talento pela instituição artística paulista mais importante de então, já então sob orientação de Ramos de Azevedo ${ }^{22}$.

\footnotetext{
${ }^{19}$ Segundo Ana Luisa Martins, Sarah Bernardt, a famosa atriz francesa, esteve três vezes no Brasil - em 1886, 1893 e 1905. A cidade de São Paulo, embora não tivesse um teatro à altura da diva, tinha um público interessado e, mais do que isso, muito abonado. Em 1893, ao deixar a cidade, definiu-a como a "Capital Artística do Brasil", expressão imediatamente incorporada e assumida pela sociedade local, ávida de qualificar valorativamente o seu meio. A imprensa capitalizou tal expressão e, nas episódicas matérias sobre arte, lá vinha o jargão, adotado como estatuto. E não só. Nas revistas, ele aparecia em destaque, como subtítulo ou título de seções que tratavam dos acontecimentos artísticos locais. Ver MARTINS, Ana Luiza. Revistas em revista:Imprensa e práticas culturais em tempos de República. São Paulo: Edusp, Fapesp, Imesp, 2001.

${ }^{20}$ ROSSI, Mirian Silva. Circulação e mediação da obra de arte na Belle Époque paulistana. Anais do Museu Paulista: História e Cultura Material, São Paulo,.. v. 6/7. p.83-119 (1998-1999). Editado em 2003, p. 86.

${ }^{21}$ NASCIMENTO, Ana Paula. Espaços e a representação de uma nova cidade: São Paulo (18951929).Tese (doutorado) - Faculdade de Arquitetura e Urbanismo, Universidade de São Paulo, São Paulo, 2009, p. 368.

${ }^{22}$ O Liceu de Artes e Ofícios foi criado em 1873, com a denominação de Sociedade Propagadora da Instrução Popular, por iniciativa de Carlos Leôncio da Silva Carvalho (1847 - 1912) e um grupo de sócios ligados às elites cafeicultoras locais. No início, o objetivo da instituição era a formação de mão-de-obra especializada para a indústria. No entanto, a partir de 1895, passa por uma reforma, dirigida pelo engenheiro Ramos de Azevedo (1851 - 1928), que pretende criar as bases de uma Escola de Belas Artes de São Paulo. A ênfase no ensino de desenho, pintura e escultura se articula ao plano de Ramos de Azevedo de transformar o Liceu em um centro de belas-artes, com organização de exposições, ateliês de artistas e formação de uma pinacoteca. Ver BELLUZZO, Ana Maria de Moraes. Artesanato, arte e indústria. Tese (doutorado) - Faculdade de Arquitetura e Urbanismo, Universidade de São Paulo, São Paulo, 1988. E também em Enciclopédia Itaú cultural em:

http://www.itaucultural.org.br/aplicExternas/enciclopedia IC/index.cfm?fuseaction=instituicoes texto\&cd v erbete $=4987 \&$ cd idioma $=28555$, acesso em $20 / 11 / 2012$
} 
Seu prestígio crescente fica ainda mais evidente quando se observa que seu nome passou a ser constantemente citado em artigos de alguns dos jornais mais importantes da capital, como O Estado de São Paulo ${ }^{23}$ e Correio Paulistano ${ }^{24}$. Por meio dessas notícias, é possível constatar que o artista participou de diversas exposições, como a Exposição de Belas Artes e Artes Industriais ${ }^{25}$, em 1902, em que foi expositor e também fez parte da comissão artística ${ }^{26}$. Essa foi a primeira exposição coletiva nacional de importância na capital, viabilizada por artistas e personalidades da sociedade paulistana e que contou com a presença do presidente do Estado, Bernardino de Campos ${ }^{27}$.

A participação em exposições era o meio mais consagrado de projetar o nome do artista e permitir que o público entrasse em contato com suas obras, tornando possível a venda dos quadros expostos ou a encomenda de outros. Nesse mesmo ano de 1902, por exemplo, Oscar Pereira da Silva recebeu a tarefa de realizar dois quadros com a temática industrial ${ }^{28}$, para serem expostos na Vila Penteado ${ }^{29}$,

\begin{abstract}
${ }^{23}$ O jornal O Estado de São Paulo foi publicado pela primeira vezem 1875 com o nome de Província de $S$. Paulo. Com o advento da República teve seu nome alterado para $O$ Estado de São Paulo. Segundo Bárbara Weinstein, já no início do século XX era um dos jornais mais influentes e respeitados do estado. O seu conteúdo padrão, que continha colunas como O Café, O Cambio e O movimento dos Portos, demonstra que os seus principais leitores integravam as elites paulistas, sobretudo, àquela ligada à produção cafeeira. Ver WEINSTEIN, Barbara. Impressões da elite sobre os movimentos da classe operária: a cobertura da greve em O Estado de São Paulo, 1902- 1907. In CAPELATO, Maria Helena Rolim; PRADO, Maria Ligia Coelho. O Bravo Matutino. Imprensa e Ideologia: O Jornal O Estado de S.Paulo. São Paulo: Alfa-Omega, 1980.
\end{abstract}

24 O Correio Paulistano foi o segundo jornal diário de São Paulo, surgido em 1854. Teve como diretor Antônio Prado. Com os acontecimentos de quinze de novembro, foi "o primeiro órgão a considerar irreversível a República. Sua tiragem, de 850 exemplares nesse ano, passou a 1800 e, em 1904, havia chegado a 8500". Ver SODRÉ, Nelson Werneck. História da imprensa no Brasil. Rio Janeiro: Mauad, 1999, p. 225.

${ }^{25}$ O Estado de São Paulo, 25 de junho de 1902.

${ }^{26}$ Ele expôs os quadros "Escrava romana" e "Criação da vovó". Ver NASCIMENTO, Ana Paula. Espaços e a representação de uma nova cidade: São Paulo (1895-1929). São Paulo: USP, 2009. Tese (doutorado) - Faculdade de Arquitetura e Urbanismo, Universidade de São Paulo, São Paulo, 2009.

${ }^{27}$ Segundo Mirian Rossi, a direção da exposição esteve a cargo de Ramos de Azevedo, Bento Bueno, Antonio Prado, Paula Souza, Carlos de Campos e Garcia Redondo. Ver ROSSI, Mirian Silva. Circulação e mediação da obra de arte na Belle Époque paulistana. Anais do Museu Paulista: História e Cultura Material São Paulo, v. 6/7. p.83-119 (1998-1999). Editado em 2003, p.91.

${ }^{28}$ Vale lembrar que um dos responsáveis pela direção da Exposição de Belas Artes e Artes Industriais de 1902 era Antonio da Silva Prado, pai de Antonio da Silva Prado Junior, que era genro de Antônio Álvares Penteado. Além dos laços familiares estabelecidos entre os Prados e os Penteados, as duas famílias estariam literalmente "sob o mesmo teto", a partir de 1902. Uma vez que projeto da Vila Penteado previa a divisão do edifício em duas residências distintas para abrigar tanto a família de Antonio Álvares Penteado, como aquela de seu genro Antonio Prado Júnior. Apesar da interdependência, tratava-se de uma separação efetiva de espaços, com entradas independentes e programas próprios de habitação. Ver LOURENÇO, Maria Cecília França. (org.). Bens imóveis tombados ou em processo de tombamento da USP. São Paulo: Edusp, Imprensa Oficial do Estado de São Paulo, 1999, p. 126.

${ }^{29}$ Sobre os quadros de Oscar Pereira da Silva na Vila Penteado ver LOURENÇO, Maria Cecília França. Vila Penteado: Memória e Futuro. In Vila Penteado: 100 anos. São Paulo: FAUUSP, 2002, p.94-105. 
residência então em construção e pertencente ao conde Antônio Álvares Penteado. O encomendante era sogro de um dos filhos de Antônio da Silva Prado, membro da comissão organizadora da exposição de 1902, o que certamente favoreceu a aproximação de Oscar Pereira da Silva e de seu novo mecenas, assim como com outros membros da família Silva Prado.

Finalizadas em 1903, $A$ indústria no século XV (figura1) e $A$ indústria no século $X V I I I$ (figura 2), que contam com aproximadamente $280 \times 150 \mathrm{~cm}$, foram dispostas no grande hall da Vila Penteado, em local privilegiado para recepção do visitante e da família na residência de Antônio Álvares Penteado. Os dois quadros, juntamente com um terceiro de Carlo de Servi, Glorificação da Indústria, formam o conjunto intitulado Alegorias da Indústria Nacional, tema que se remete ao seu mecenas, proprietário de importantes indústrias têxteis em São Paulo ${ }^{30}$.

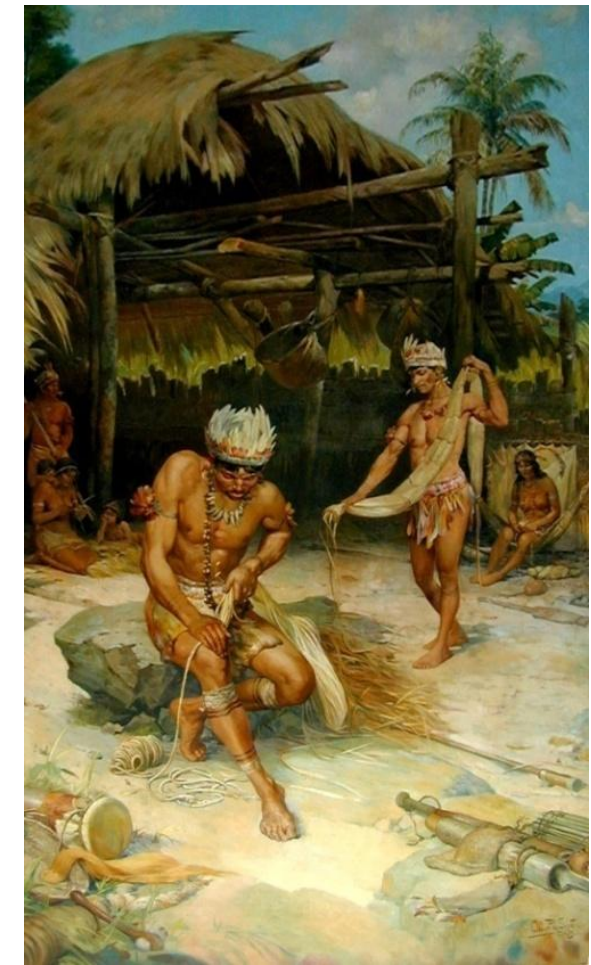

Figura1- Oscar Pereira da Silva. Indústria Nacional no século XV, 1903, Vila Penteado. Fotografia de Candida Maria Vuolo.

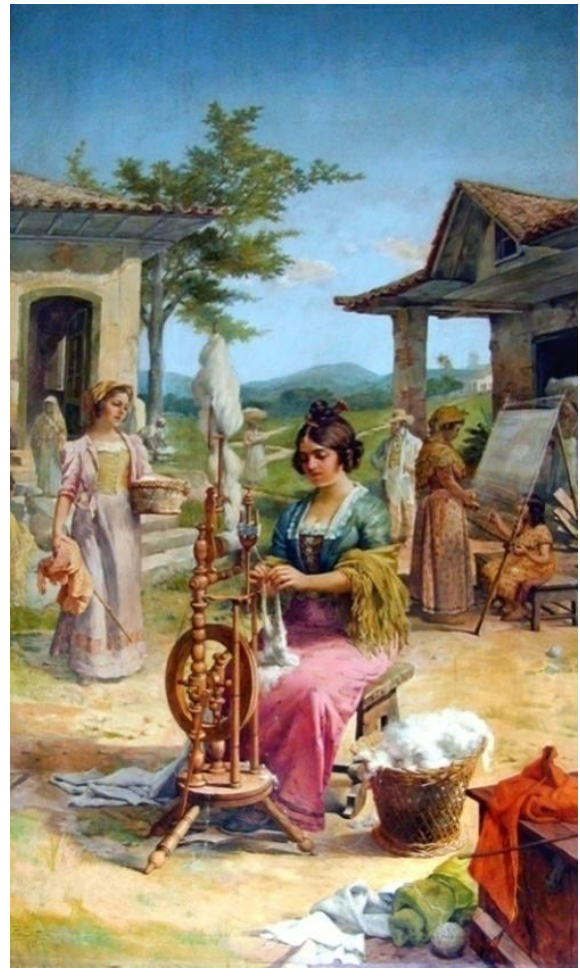

Figura2 - Oscar Pereira da Silva. $A$ indústria nacional no século XVIII, 1903, Vila Penteado. Fotografia de Cândida Maria Vuolo.

MONTEIRO, Michelli C. Scapol. Uma interpretação da história do Brasil nas telas de Oscar Pereira da Silva para a Vila Penteado. In 110 anos da Vila Penteado. São Paulo: FAUUSP, 2012 (no prelo).

${ }^{30}$ Antônio Álvares Leite Penteado (1852-1912), conde Álvares Penteado por título papal, nasceu em Mogi Mirim e era descendente de proprietários rurais. Fundou duas importantes indústrias têxteis em São Paulo, as fábricas Santana e Penteado, no Brás. Ver HOMEM, Maria Cecília Naclério. O Palacete Paulistano e outras formas urbana de morar da elite cafeeira (1867-1918). São Paulo: Martins Fontes, 1996. E LOURENÇO, Maria Cecília França. Vila Penteado: Memória e Futuro. In Vila Penteado: 100 anos. São Paulo: FAUUSP, 2002, p.94-105. 
Para os Silva Prado, centro da elite paulista da virada do século, Oscar Pereira da Silva pintou, por exemplo, Uvas da chácara de Dona Veridiana, de 1905, cinco anos antes da morte da matriarca. Outros membros da família foram representados em retratos:

Numa das vitrinas da casa Garraux ${ }^{31}$ estiveram expostos, durante muitos dias, dois retratos a óleo do falecido Dr. Martinho Prado Junior e sua exma. Esposa, d. Albertina Prado.

São ambos trabalho do distinto pintor Oscar Pereira da Silva, e devemos acrescentar que sua fatura pode realçar os créditos do artista.

Nesses dois retratos, não há a admirar apenas a semelhança do trabalho, a ciência do colorido e a correção do desenho. Também neles brilha um grande talento de minúcias: flexibilidade das roupas, a luz dos cabelos e dos olhos, a vida expressiva da fisionomia.

Esses dois retratos vão ser ou já estão colocados numa das salas da Santa Casa de Misericórdia, ao lado de outros que ali existem ${ }^{32}$.

A notícia ilustra com clareza a inserção de Oscar Pereira da Silva não apenas entre os membros da mais prestigiosa família paulistana de então ${ }^{33}$, mas também na solene Irmandade da Misericórdia. A Santa Casa abriga, até hoje ${ }^{34}$, diversos retratos realizados por Pereira da Silva, como o do Dr. José Alves de Cerqueira César ${ }^{35}$, pintado em 1903; o do Dr. Alberto Vieira de Carvalho ${ }^{36}$, realizado em 1904; o do Dr. Francisco Antonio de Souza Queiroz Júnior ${ }^{37}$, de 1906; o do Dr. Francisco de Paula

\footnotetext{
${ }^{31}$ Com a falta de espaços próprios de exposição de quadros, era comum artistas utilizarem casas de comércio, como a citada. Segundo Miriam Silva Rossi, a Casa Garraux destacou-se pela regularidade com que expunha obras de arte em suas vitrinas que funcionavam, possivelmente, como um mostruário do trabalho de vários artistas, que ali expunham um quadro ou uma pequena escultura. Ver ROSSI, Mirian Silva. Circulação e mediação da obra de arte na Belle Époque paulistana. Anais do Museu Paulista: História e Cultura Material, São Paulo, , v. 6/7. p.83-119 (1998-1999). Editado em 2003.

32 O Estado de São Paulo, 22 de novembro de 1907.

${ }^{33}$ Martinho da Silva Prado Junior, também conhecido como Martinico Prado, foi deputado da Assembleia Provincial de São Paulo pelo Partido Republicano Paulista.

${ }^{34}$ Hoje este acervo está reunido no Museu da Santa Casa da Misericórdia de São Paulo. Agradeço a Maria Nazarete de Barros Andrade, coordenadora e organizadora do Museu, que gentilmente me atendeu e forneceu informações de suma importância sobre as telas de Oscar Pereira da Silva que pertencem ao acervo do Museu da Santa Casa da Misericórdia de São Paulo.

35 José Alves de Cerqueira César foi provedor da Santa Casa da Misericórdia de 1900 a 1902 .Informação retirada de Relatório de quadros existentes no Museu da Santa Casa da Misericórdia, organizado por Maria Nazarete de Barros Andrade.

${ }^{36}$ Alberto Vieira de Carvalho foi mordomo do Asilo dos Expostos da Irmandade da Santa Casa da Misericórdia no período de 1900 a 1903. Informação retirada de Relatório de quadros existentes no Museu da Santa Casa da Misericórdia, organizado por Maria Nazarete de Barros Andrade.

${ }^{37}$ Francisco Antonio de Souza Queiroz Júnior foi provedor da Irmandade da Santa Casa da Misericórdia de São Paulo de 1902 a 1917.Informação retirada de Relatório de quadros existentes no Museu da Santa Casa da Misericórdia, organizado por Maria Nazarete de Barros Andrade.
} 
Ramos de Azevedo ${ }^{38}$, de 1906; e Dr. Arnaldo Augusto Vieira de Carvalho ${ }^{39}$, de 1907. Estas eram figuras de relevância não apenas no cenário político paulistano, como também no religioso, o que justifica a presença desses quadros nessa instituição. Os retratos revelam, portanto, o bom relacionamento de Oscar Pereira da Silva com um setor específico da elite - os católicos.

Oscar Pereira da Silva não fez apenas telas para particulares, mas também recebeu encomendas e vendeu obras a instituições públicas. São exemplo disso as pinturas executadas em 1897, realizadas logo após sua chegada em São Paulo, para o teto do salão principal da Escola Politécnica de São Paulo, hoje destruídas. Foi, no entanto, com a obra Desembarque de Pedro Álvares Cabra ${ }^{40}$, que o artista ganhou maior visibilidade e se tornou alvo constante da imprensa paulista. Segundo Fabio Rodrigo de Moraes $^{41}$, a tela foi adquirida pelo governo do estado por 8:000 $\$ 000^{42}$ (oito contos de réis) e enviada ao Museu Paulista, em 1902, processo que foi muito noticiado nos jornais. Sem dúvida, ter um quadro histórico exposto nessa instituição era um passo importante na carreira do artista. E o reconhecimento do seu talento e

\footnotetext{
${ }^{38}$ Francisco de Paula Ramos de Azevedo, o famoso engenheiro-arquiteto nascido em Campinas, foi Irmão Protetor e membro efetivo da Comissão de Obras da Irmandade da Santa Casa da Misericórdia de São Paulo de 1902 a192.9 Informação retirada de Relatório de quadros existentes no Museu da Santa Casa da Misericórdia, organizado por Maria Nazarete de Barros Andrade.

${ }^{39}$ Arnaldo Augusto Vieira de Carvalho, médico, foi definidor irmão benfeitor e segundo diretor clínico da Irmandade da Santa Casa da Misericórdia de São Paulo.Informação retirada de Relatório de quadros existentes no Museu da Santa Casa da Misericórdia, organizado por Maria Nazarete de Barros Andrade.

${ }^{40}$ Oscar Pereira da Silva, Desembarque de Pedro Álvares Cabral em Porto Seguro em 1500, óleo sobre tela, $188 \times 332 \mathrm{~cm}, 1900$, acervo do Museu Paulista da USP. É importante destacar que esta obra em alguns documentos da época, o título dessa obra aparece como Descoberta do Brasil. Além disso, é comum ver como data da tela o ano de 1922, como na enciclopédia Itaú Cultural. No entanto, a obra é certamente anterior. $\mathrm{O}$ artista assina a obra como Oscar P. da Silva, 1900 c.i.e.. Além disso, ela está citada no livro do tombo de 1911 da Pinacoteca, na primeira página.
}

${ }^{41}$ MORAES, Fabio Rodrigo de. Uma coleção de história em um museu de ciências naturais: o Museu Paulista de Hermann von Ihering. Anais do Museu Paulista: História e Cultura Material,São Paulo, v. 16, p. 203-233, 2008, p. 214.

${ }^{42}$ É possível fazer-se comparações com o que se comprava com oito contos de réis para que se possa dimensionar o valor do quadro. Segundo anúncios do jornal $O$ Estado de São Paulo, em 14 de fevereiro de 1902 , foram penhorados "quatro moradas de casas, sob os $n^{o s} 4,6,8,10$, com entrada pela rua Monsenhor Andrade n. 36, distrito do Braz, desta capital, com uma porta e uma janela de frente cada uma, e uma dependência também em cada uma", elas haviam sido avaliadas por dez contos de réis, como não havia encontrado comprador, a valor foi reduzido para oito contos e cem mil réis (8:100\$000). Com essas comparações é possível ter uma ideia do valor da obra. Comparando com quadros adquiridos nesse mesmo período, é possível citar o de Benedito Calixto Fundação de São Vicente,adquiridoem 1900 por dez contos de réis e, no ano seguinte, o Museu Paulista encomendou retratos ao mesmo artista por um conto de réis (1:000\$000). Segundo Moraes, um conto de réis era a quantia equivalente a um mês da verba de expediente da instituição. Ver MORAES, Fabio Rodrigo de. Uma coleção de história em um museu de ciências naturais: o Museu Paulista de Hermann von Ihering. Anais do Museu Paulista: História e Cultura Material,São Paulo, v. 16, p. 203-233, 2008, p. 214. 
competência ${ }^{43}$ pode ser constatado pelo fato de ter sido ele o requisitado, em 1906, a realizar obras de conservação na famosa tela "Independência ou Morte" ${ }^{44}$, de Pedro Américo.

A fim de estreitar os laços com o Museu Paulista, logo após a finalização do trabalho de conservação, o artista doou uma tela, no mesmo ano de 1906, que ficou conhecida com o nome de Guerreiro Carajá ${ }^{45}$. Segundo as palavras do diretor interino, Rodolpho Ihering, o quadro era belo e perfeito, e constituía uma inestimável dádiva, que seria utilizada para ornamentar a sala etnográfica ${ }^{46}$, ilustrando, "quase ao vivo", o porte do valente indígena. Ihering conclui felicitando o Oscar Pereira da Silva pela "perfeição artística da tela, que será uma peça querida dos visitantes do Museu Paulista"47. Importante notar que essa doação ocorreu apenas dois meses antes do artista ser referido, pelo Correio Paulistano na notícia que abre este capítulo, como se dedicando à elaboração um quadro histórico inspirado no passado paulista. Útil para provar seu talento artístico e ainda para que fosse sempre lembrado e visto no grande museu de história do estado, a tela Guerreiro Carajá pode ser entendida como uma maneira de "preparar o terreno" para a grande obra que Oscar Pereira da Silva, certamente, já planejava para os acervos estaduais. Resta entender, no entanto, os motivos que levaram esse artista a se embrenhar em uma empreitada tão arriscada quanto a realização de uma tela onerosa como a Fundação de São Paulo, viabilizada às suas expensas.

\footnotetext{
${ }^{43} \mathrm{Na}$ correspondência trocada entre o diretor do Museu Paulista e o secretário do Interior para o pedido de autorização para a realização de trabalhos de conserto e conservação da tela de Pedro Américo, "Independência ou Morte", Ihering diz que irá encarregar "um pintor de toda competência como julgo ser o sr. Oscar Pereira da Silva". Ver correspondência de 08 de outubro de 1906, pasta 84, acervo do Museu Paulista da USP.

${ }^{44}$ Pedro Américo, Independência ou Morte, óleo sobre tela, $415 \times 760 \mathrm{~cm}, 1888$, acervo do Museu Paulista da USP, São Paulo.

${ }^{45}$ O paradeiro da obra Guerreiro Carajá é desconhecido, pois ela não se encontra no acervo do Museu Paulista. A obra é citada no relatório anual de 1906, na lista de objetos oferecidos ao Museu, e aparece também no Inventário oㅜ 6, de 1916, porém, nos inventários subseqüentes, não há menção à tela. No Guia da secção histórica do Museu Paulista, elaborado por Affonso Taunay, a tela é citada como pertencente à sala B12, dedicada à etnografia brasileira. Segundo Taunay lá haveria um quadro em que estaria representado um índio carajá, segundo ele, "de corpo inteiro e em traje de gala". A descrição é acompanhada de uma foto. TAUNAY, Affonso de E. Guia da Secção Histórica do Museu Paulista. São Paulo: Imprensa Official do Estado, 1937, p. 105.Poderia se supor que a tela haveria sido transferida para a Pinacoteca do Estado, porém, ela também não pertence a este acervo, conforme informação fornecida por Adriana MiyatakeYokoyama, especialista em museologia do Núcleo de Gestão Documental do Acervo da Pinacoteca.

${ }^{46}$ A tela é citada no Inventário $n^{\circ}$ 6, de 1916 , na página 232, dedicada à sala B16, que diz "Na parede desta mesma sala: Uma tela de Oscar Pereira da Silva denominada O guerreiro Carajá".

${ }^{47}$ Ver correspondência de 12 de novembro de 1906, pasta 84, acervo do Museu Paulista da USP
} 
Foi possível perceber que na década iniciada em sua chagada em 1896, Oscar Pereira da Silva conseguiu conquistar rapidamente um espaço privilegiado nos meios intelectuais, políticos e culturais de São Paulo, incluindo também um público amplo capaz de adquirir seus quadros para pinacotecas privadas ou para decoração. Uma notícia veiculada no Correio Paulistano, em janeiro de 1906, resume com clareza o que se pretendeu demonstrar até agora:

Conforme dissemos em nosso último número, inaugurou-se ontem, à rua Quinze de Novembro, esquina da rua do Palácio, a exposição de quadros do pintor Oscar Pereira da Silva.

São cinqüenta pequenas telas em que o artista demonstrou o valor de sua técnica e o talento de que é dotado.

Oscar Pereira da Silva, cujo merecimento já foi constatado em trabalhos de grandes dimensões e de dificílima execução, como o Desembarque de Pedro Álvares Cabral e outros, quis mostrar-nos que a miniatura também lhe era familiar, e apresenta-se desta vez uns adoráveis quadrinhos cheios de muito encanto pela muita arte em que neles se encontra.

O pintor pretendeu organizar uma exposição acessível a todos. Quis fazer uma arte que a todos agradasse, são saindo da linha distinta de um artista que estremece o seu ideal artístico e o compreende superior a conveniências é, sem se tornar um borrador de telas, dá-nos uma excelente coleção de trabalhos que muito o recomendam pela delicadeza e carinho com que foram trabalhados.

(...)

Oscar Pereira da Silva deve sentir-se satisfeito com a impressão que a todos ocasionou a sua exposição atual, e, sem exagerarmos, diremos que o artista vai fazer um sucesso, colhendo ainda esses louros merecidos que lhe saberá conferir o nosso público, tão amante do que é arte.

A respeito dos trabalhos expostos, havemos de dizer com mais vagar a nossa impressão ${ }^{48}$.

As exposições individuais de Oscar Pereira da Silva eram noticiadas pelos jornais, que divulgavam o local e a duração delas, elogiavam e descreviam os trabalhos expostos, incitavam o público a visitá-las e ainda rogavam benesses ao seu sucesso. Nessa notícia está explícita também a admiração conquistada pelo artista, que era capaz de fazer cinqüenta quadros, a fim de agradar a todos os gostos e ser acessível a todos, já que, como foi dito, as exposições constituíam-se como importantes espaços para a venda e a divulgação do trabalho do pintor. Percebe-se pelo excerto que Oscar Pereira da Silva era um pintor de muitas faces, capaz de pintar paisagens, retratos, cenas de gênero e, claro, "quadrinhos" capazes de assegurar

\footnotetext{
${ }^{48}$ Correio Paulistano, 29 de janeiro de1906.
} 
recursos mais frequentes do que aqueles oriundos das grandes encomendas. Contudo, o que the deu maior destaque havia sido a tela Desembarque de Pedro Álvares Cabral em Porto Seguro em 1500 (figura 3), que mesmo após seis anos de sua elaboração ainda é retomada nas notícias para provar o talento e competência do artista, consagrado pelo Estado ao adquirir uma grande tela histórica.

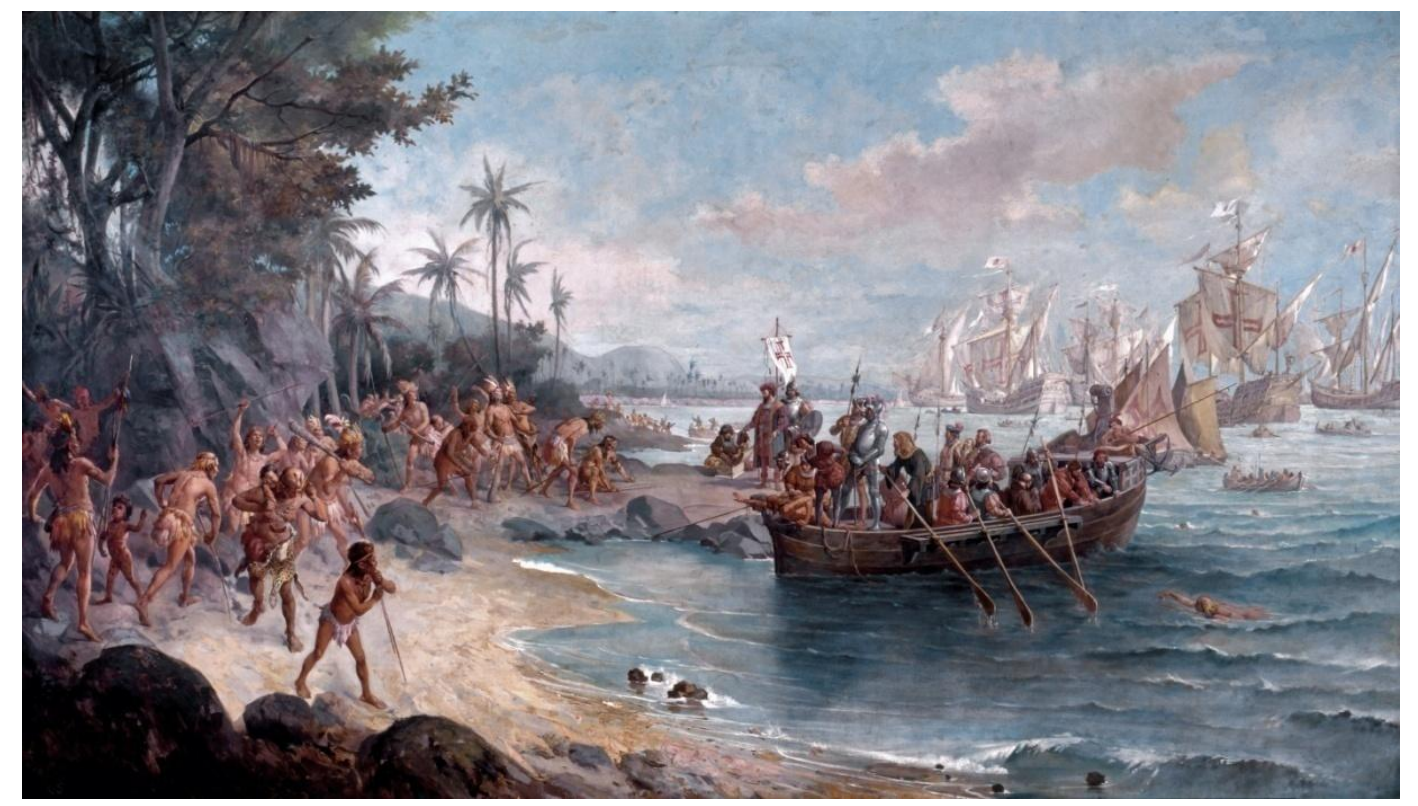

Figura3 - Oscar Pereira da Silva, Desembarque de Pedro Álvares Cabral em Porto Seguro em 1500, 1900, óleo sobre tela, 190 x 333cm. Acervo do Museu Paulista da USP, São Paulo. Reprodução fotográfica José Rosael e Hélio Nobre.

A pintura histórica era considerada o gênero hierarquicamente superior aos outros justamente por combinar retrato, natureza morta e paisagem através de uma articulação complexa, pautada pela narrativa. Ser consagrado como pintor de história era condição certamente almejada também por Oscar Pereira da Silva. A despeito da sua habilidade para realizar telas tão diversas, que facilmente poderiam ser vendidas a particulares, o artista também precisava dedicar tempo e dinheiro na realização de mais uma obra de vulto, capaz de lhe garantir notabilidade e, assim, ser mais requisitado para realização de obras para o Estado. A tela Desembarque de Pedro Álvares Cabral em Porto Seguro em $1500^{49}$,apesar de lhe ter concedido muitos louros e provado a sua capacidade técnica e artística, não havia sido suficiente para the imputar a posição almejada definitivamente.Faltava-Ihe um diferencial, que permitisse

\footnotetext{
${ }^{49}$ A tela Desembarque de Pedro Álvares Cabral em Porto Seguro em 1500, feita por Oscar Pereira da Silva não foi encomendada, mas foi ofertada pelo artista, como é possível observar na notícia do jornal $O$ Estado de São Paulo de 27 de julho de 1900, p. 2. Além disso, sua venda não se concretizou facilmente, como será exposto adiante.
} 
atrair a atenção das autoridades de São Paulo: a solução era, por certo, retratar grandiosamente o passado paulista.

lluminar o passado dos paulistas era algo que, na virada do século, estava na ordem do dia. Espaços institucionais estavam sendo criados com a finalidade de definir os contornos da natureza, do território e do povo paulistas, visando construir uma identidade para São Paulo, além de contribuírem para a divulgação das potencialidades econômicas e das ideias modernizadoras.

Dessa ambição transformadora no presente é exemplo a Comissão Geográfica e Geológica,criada em 1886 e presidida por Orville Derby.Ela era encarregada do mapeamento do estado para facilitar e racionalizar a ocupação de suas terras, propiciando ainda o contato das elites dirigentes com engenheiros, geólogos e geógrafos, que se tornariam expoentes dessas áreas em São Paulo ${ }^{50}$.

Outra instituição de grande relevo no conhecimento das potencialidades do estado de São Paulo foi o já citado Museu Paulista ${ }^{51}$ (MP), criado em 1893 e aberto ao público em $1895^{52}$, vinculado à Comissão Geográfica e Geológica. Embora seu núcleo original houvesse sido formado com a aquisição da coleção de Joaquim Sertório, que continha sobretudo artefatos de história, como peças de mobiliário, jornais e objetos indígenas, o Museu Paulista foi definido sobretudo como um museu de História Natural. Tal tipologia museal, de grande prestígio e vigor na segunda metade do século XIX, foi adotado como eixo central do museu estadual, superando imensamente a visibilidade das coleções históricas até 1917. Seu primeiro diretor foi Hermann von Ihering, zoólogo alemão, que procurou reproduzir na instituição traços do modelo europeu, com base em um saber evolutivo, classificatório e pautado no modelo das ciências biológicas. O museu deveria servir também à instrução pública ${ }^{53}$, para produção e difusão do conhecimento. Ter um museu que se pretendia moderno e científico, era uma maneira de dar visibilidade ao estado de São Paulo, além dele ser

${ }^{50}$ FERREIRA, Antonio Celso. A epopéia bandeirante: letrados, instituições, invenção histórica (1870 1940). São Paulo: Editora Unesp, 2002, p. 96.

51 O edifício que abriga o Museu Paulista, projetado pelo arquiteto italiano Tommaso Gaudenzio Bezzi, começou a ser construído em 1885, portanto, ainda no período Imperial. Foi idealizado com uma função comemorativa: era uma homenagem à emancipação do Brasil, por isso fora edificadono local em que haveria ocorrido o grito da independência. As obras, no entanto, só findaram em 1890, quando já estava instaurado o regime republicano. O edifício ficou fechado até 1893, quando se decidiu que ele abrigaria o Museu Paulista. VER MORAES, Fábio Rodrigo de. Uma coleção de história em um museu de ciências naturais: o Museu Paulista de Hermann Von Ihering. Relatório (Iniciação científica), Museu Paulista, 2006, inédito(depositado no Serviço de Documentação Textual e Iconografia, Museu Paulista da USP) e SCHWARCZ, Lilia Moritz.O espetáculo das raças: cientistas, instituições e questão racial no Brasil (18701930). São Paulo: Companhia das Letras, 2011.

${ }^{52}$ Segundo Moraes, entre 1893 e 1895 as coleções foram sendo transferidas para o Monumento do Ipiranga e, em 7 de setembro de 1895, em uma comemoração solene, inaugurava-se o Museu Paulista. 
utilizado, pela elite dirigente, como instrumento de legitimação do poder exercido em âmbito nacional ${ }^{54}$.

O domínio da história tinha, entretanto, outra instituição balizadora. Embora fosse privada, desempenharia claramente um papel de caráter público, gozando de grande prestígio durante a Primeira República e inserindo-se na órbita do poder político dominante do estado. Trata-se do Instituto Histórico e Geográfico de São Paulo (IHGSP), criado em novembro de 1894. O objetivo dessa instituição era construir um passado unitário para um país de dimensões continentais e segmentado em regiões de povoamento e cultura muito distintos, além de composto por raças muito diversas - problemática que o Instituto Histórico e Geográfico Brasileiro (IHGB) já havia enfrentado anos antes ${ }^{55}$. Em um novo contexto, coube aos fundadores do IHGSP revisitar os marcos da nacionalidade, reescrever a história nacional, recriar um passado, fundamentar mitos, ordenar fatos e singularizar personagens, a partir de um novo protagonista: o povo paulista ${ }^{56}$. A mais que célebre passagem da Apresentação do primeiro número da revista do IHGSP é dessa ambição documento inescapável:" $A$ história de S. Paulo é a própria história do Brasil ${ }^{57}$.

Em outros estados também estavam sendo criadas instituições congêneres, que pretendiam impor a sua especificidade regional como eixo para a liderança da nação. Contudo, em São Paulo isso foi mais evidente e, certamente, muito mais eficaz. A sua situação econômica e política garantiu uma posição sui generis à entidade paulista, que contava com sede e recursos próprios, que lhe dava condições de lutar pela preponderância sobre os institutos de outras regiões ${ }^{58}$. A busca pela superioridade intelectual e científica vinha acompanhada da luta em torno de interesses econômicos e projetos políticos divergentes. Era de São Paulo que os sócios do IHGSP pretendiam irradiar suas luzes, não só no espaço regional, como em toda nação.E, se coube aos historiadores do IHGSP reescrever a história do país a

\footnotetext{
${ }^{54}$ SCHWARCZ, Lilia Moritz.O espetáculo das raças: cientistas, instituições e questão racial no Brasil (1870-1930). São Paulo: Companhia das Letras, 2011, p. 79. MENESES, Ulpiano Bezerra de. Museu Paulista. Estudos Avançados, São Paulo, v. 8, n. 22, p. 573-578, 1994, p. 573.

${ }^{55}$ É fundamental destacar que o contexto de criação do IHGB era completamente distinto ao do IHGSP. A instituição carioca foi criada em 21 de outubro de 1838 , momento em que o país buscava proteção contra a "revolução". De maneira que os "princípios republicanos anárquicos"são rejeitados, e a manutenção da monarquia é tomada como garantia e pressuposto para a integração do país. Ver GUIMARÃES, Manoel Luiz Salgado. Historiografia e nação no Brasil 1838-1857. Rio de Janeiro: Ed. UERJ, 2011, p. 69.

${ }^{56}$ FERREIRA, Antonio Celso. A epopéia bandeirante: letrados, instituições, invenção histórica (1870 1940). São Paulo: Editora Unesp, 2002, p. 94.

${ }^{57}$ Revista do Instituto Histórico e Geográfico de São Paulo, São Paulo, v. 1, 1895, p. 3.

${ }^{58}$ SCHWARCZ, Lilia Moritz.O espetáculo das raças: cientistas, instituições e questão racial no Brasil (1870-1930). São Paulo: Companhia das Letras, 2011, p. 129.
} 
partir do protagonismo paulista - liderado sobretudo pelos ancestrais bandeirantes dos lideres políticos republicanos do estado cafeicultor - , aos artistas coube a tarefa de criar imagens condizentes com esse discurso.

Os institutos tinham um papel ativo também na cultura visual republicana, já que o federalismo suscitou a produção de iconografias locais embasada em uma história regional. Muitas edificações públicas passam a abrigar em seu interior uma produção artístico-simbólica de exaltação da nação e culto patriótico, com um claro sentido pedagógico.

Procurou-se dar uma visualidade à identidade da nação brasileira que se buscava afirmar em diferentes pontos do país, por meio da criação de imagens que aludiam a um passado comum, aos mitos de origem e aos heróis venerados. Entender as raízes ilusórias que nossa história criou é também compreender a arte desse período. Os responsáveis pela memória seletiva eram, portanto, de um lado, os historiadores, que fundamentavam cientificamente uma "verdade" desejada; e, de outro, os artistas, que criavam crenças que se encarnavam num corpo de convicções coletivas. O projeto visual republicano deve ser, portanto, entendido na imbricação da expressão visual com a fonte escrita, já que a arte teria o poder de fabricar a história ${ }^{59}$.

Ciente da importância da pintura histórica num ambiente intelectual e político para os quais a história era dimensão fundamental, Oscar Pereira da Silva sabia que essa era a melhor maneira de se consagrar em São Paulo. Um novo esforço valia a pena, para tornar-se um pintor não apenas de pequenas telas decorativas ou de retratos, mas de grandes obras que viessem a ser encomendadas, para serem expostas ao grande público em espaços privilegiados. Essa intenção, respaldada no sucesso anterior de Desembarque de Pedro Alvares Cabral, já era sugerida expressamente pela imprensa:

Não fosse a necessidade de agradar a todos os paladares, Oscar não faria uma exposição em que exibe quadro de todos os gêneros e de todos os preços.

Com o nome e a cotação que tem no nosso microcosmo artístico, há muito que Oscar deveria ocupar-se exclusivamente da figura, fazendo, não cinqüenta quadros em um ano (produção igual a do grande Meissonier durante toda a sua existência) mas apenas dois ou três ${ }^{60}$.

\footnotetext{
${ }^{59} \mathrm{COLI}$, Jorge. Como estudar a arte brasileira do século XIX?.São Paulo: Editora Senac, 2005. SALGUEIRO, Valéria. A arte de construir a nação - pintura de história e a Primeira República. Estudos Históricos, Rio de Janeiro, v. 30, p. 3-22, 2002.

${ }^{60}$ Correio Paulistano, 09 de fevereiro de 1906.
} 
Oscar Pereira da Silva devia concordar com o que fora sugerido pelo articulista, pois apostou na elaboração de uma obra capaz de the consagrar como pintor da história paulista. A notoriedade que esta tela poderia lhe garantir é evidente, afinal, um ano antes de ela ficar pronta, portanto ainda na fase inicial de sua elaboração, ela já era noticiada com grande expectativa ${ }^{61}$.

\section{A invenção da origem urbana}

A pintura histórica tinha o poder de construir mitos e heróis, já que, por ter um caráter didático, era capaz de despertar o apoio da população, por meio de relações afetivas e simbólicas, aos projetos políticos das elites dirigentes. Como indicou Meneses, a arte possui um papel eficaz na transmissão de valores cívicos, algo bastante recorrente nas sociedades ocidentais do século XIX e da primeira metade do $X X^{62}$. O universo das imagens constituía um campo fértil para fixar sínteses simbólicas de alto impacto, uma vez que as telas eram consideradas um suporte nobre e adequado de documentação de episódios da História a serem expostos em museus.

Entre os temas retratados em telas históricas os momentos "inaugurais" eram dos mais importantes. Na América Latina, por exemplo, as telas retratando os episódios de ruptura em torno dos processos de Independência foram muito recorrentes, assim como as celebrações de contato ou de fundação de cidades. $O$ pintor francês Henri Léon Pharamond Blanchard realizou, em 1850, a obra Primeira missa na América (figura 4), enquanto Pedro Subercaseaux pintou, em 1904, Primeira missa no Chile (figura 5). As cidades da América espanhola também mereceram destaque pelos pincéis dos artistas, como a Fundação de Santiago (figura 6), de Pedro Lira, realizado em 1889, e a Fundação da Cidade do México (figura 7), realizado nesse mesmo ano, por José Jara.

\footnotetext{
${ }^{61}$ Refiro-me à notícia que abriu o capítulo, divulgada pelo jornal Correio Paulistano, em 22 de janeiro de 1907.

${ }^{62}$ MENESES, Ulpiano Bezerra de. Pintura Histórica: Documento histórico? In MENESES, Ulpiano T. Bezerra de (org.). Como explorar um museu histórico. São Paulo: Museu Paulista/USP, 1992.
} 


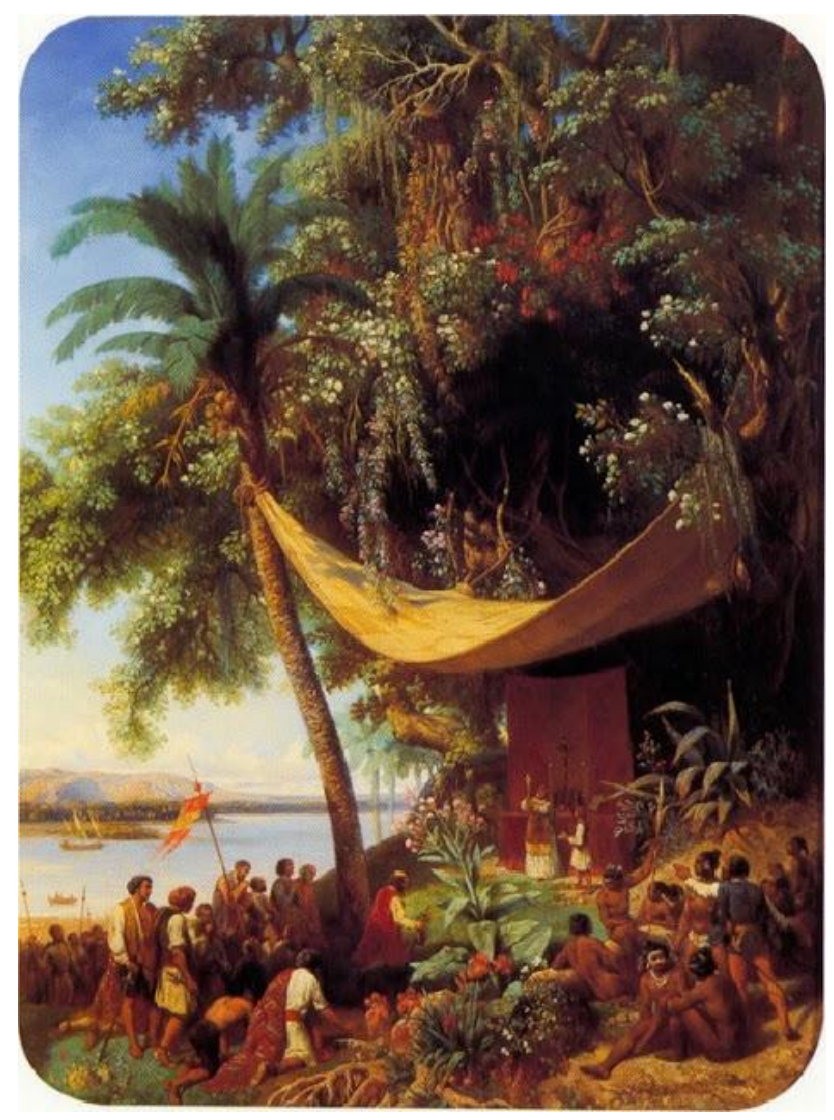

Figura 4- Henri Blachard, Primeira missa na América, 1850, acervo do Musée de Beaux-Arts de Dijon. Retirado de http://www.allposters.com/-sp/Premiere-Messe-En-AmeriquePosters i1517544 .htm. Acesso em 20/11/2012

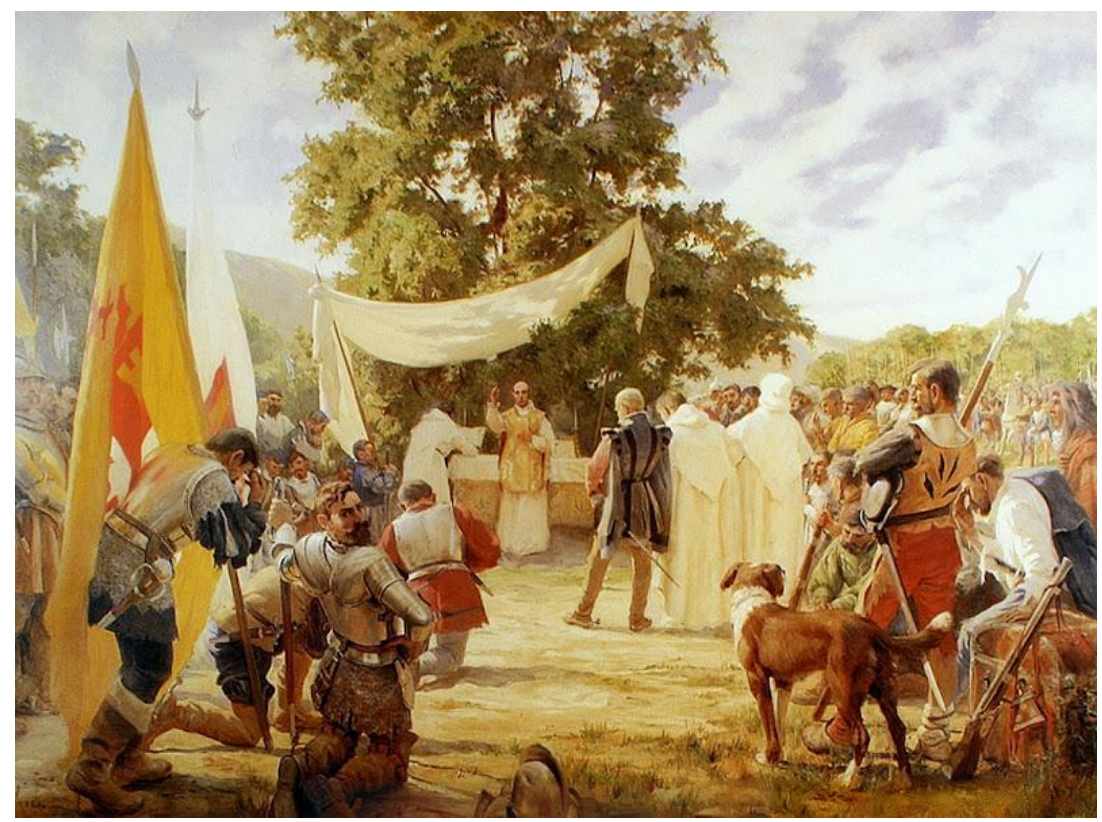

Figura5 - Pedro Subercaseaux, Primeira missa no Chile, 1904, óleo sobre tela, 150 x 200, acervo do Museo Histórico Nacional, Santiago, Chile. Retirado de http://missaaosdomingos.blogspot.com.br/2012/03/imagem-damissa-9-primeira-missa-no.html Acesso em 20/11/2012. 


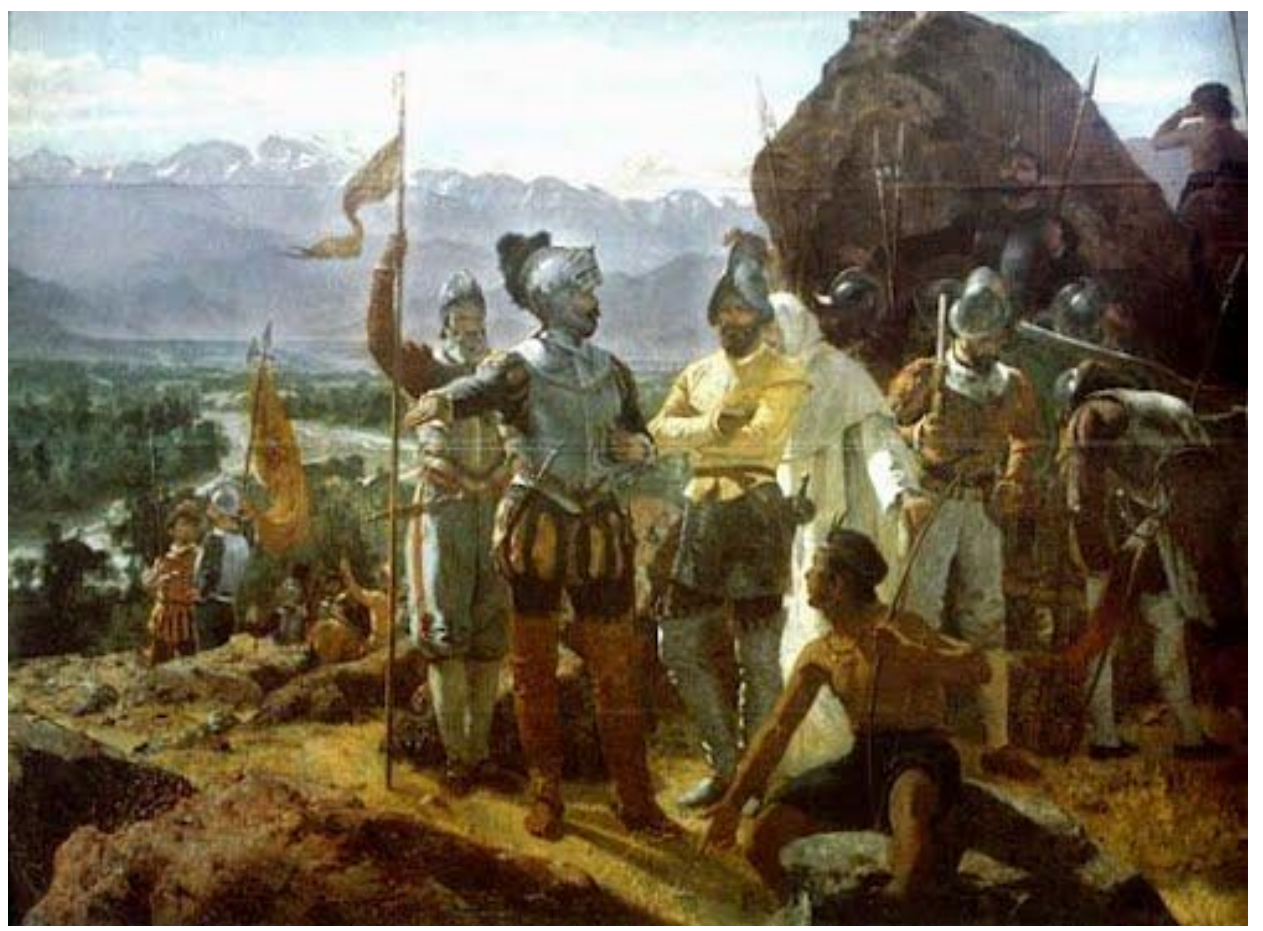

Figura6 - Pedro Lira, Fundação de Santiago, 1889, óleo sobre tela, óleo sobre tela, 92 x $123 \mathrm{~cm}$, Coleção particular. Retirado de http://pt.wikipedia.org/wiki/Santiago (Chile) Acesso 20/11/2012.

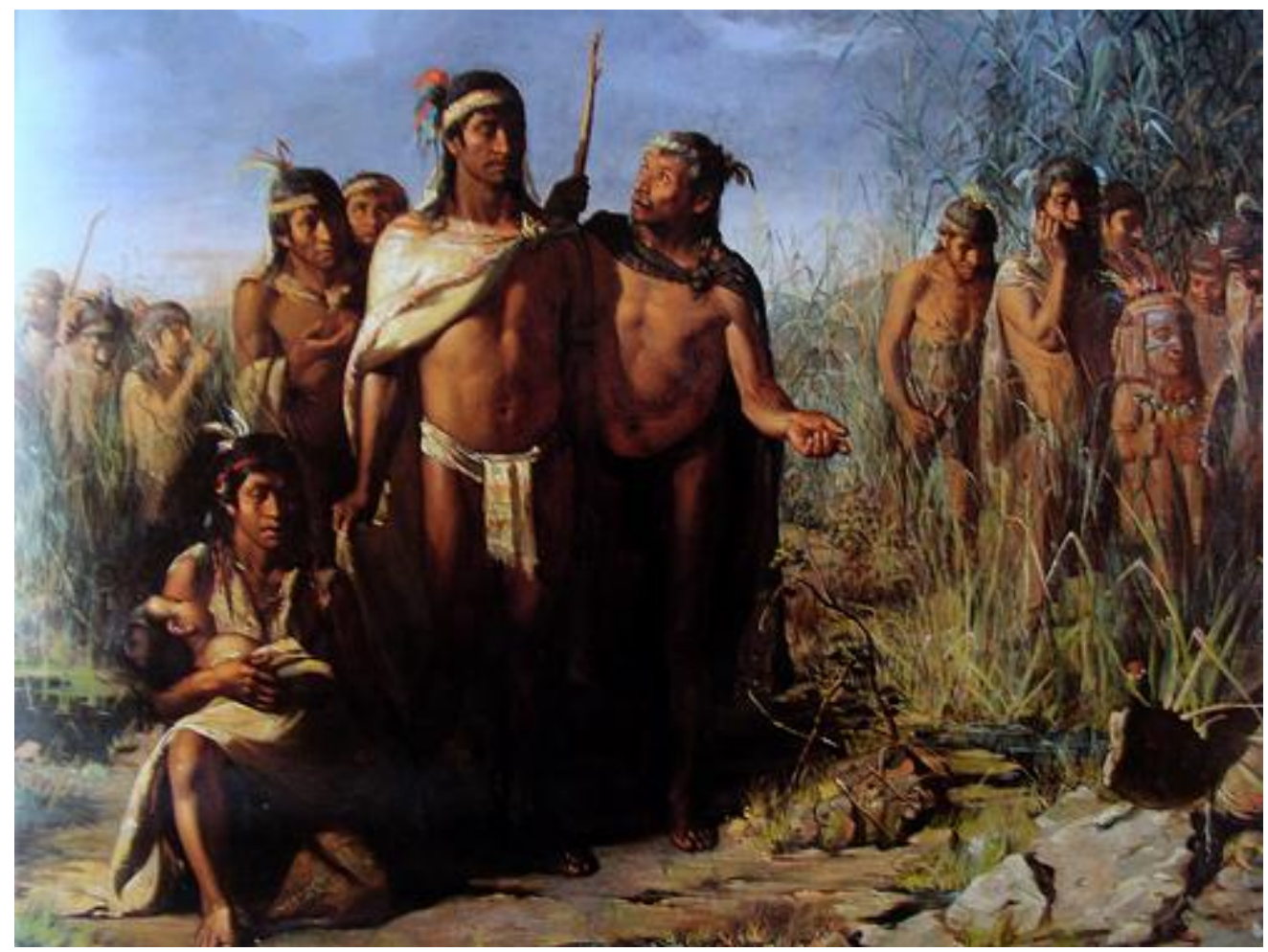

Figura7 - José Jara, Fundação da Cidade do México, 1889, óleo sobre tela, acervo do Museo Nacional de Arte, Cidade do México. Retirado de http://www.flickriver.com/photos/tags/pintoresmexicanos/interesting/ Acesso em 20/11/2012. 
Nesse mesmo sentido, a obra de Victor Meirelles, Primeira missa no Brasil (figura 8), de 1860, é exemplar em nosso país, pois criou uma imagem do que teria sido o ato primordial da origem da nação brasileira. Europeus, índios e a fé católica se fundiam na tela, selando o início de um processo histórico de conquista mediado pela fé civilizadora.

Se o objetivo dos historiadores paulistas era reescrever a história do Brasil com um ovo olhar, era imprescindível estabelecer novos marcos iniciais, inclusive de caráter imagético. Foi este o pretensioso objetivo de Oscar Pereira da Silva: dar visualidade ao ato embrionário de São Paulo, cidade que se pretendia propulsora de toda a nação. Obras que retratam as fundações de núcleos urbanos foram muito recorrentes na pintura histórica brasileira, sobretudo na passagem do século XIX para o XX, quando os estados federados passaram a encomendar e adquirir iconografias com assuntos da história regional, a fim de expô-las ao grande público. Pereira da Silva enlaçava-se nessa produção, mas com o trunfo de propor sua criação a partir da cidade mais pujante no Brasil de então.

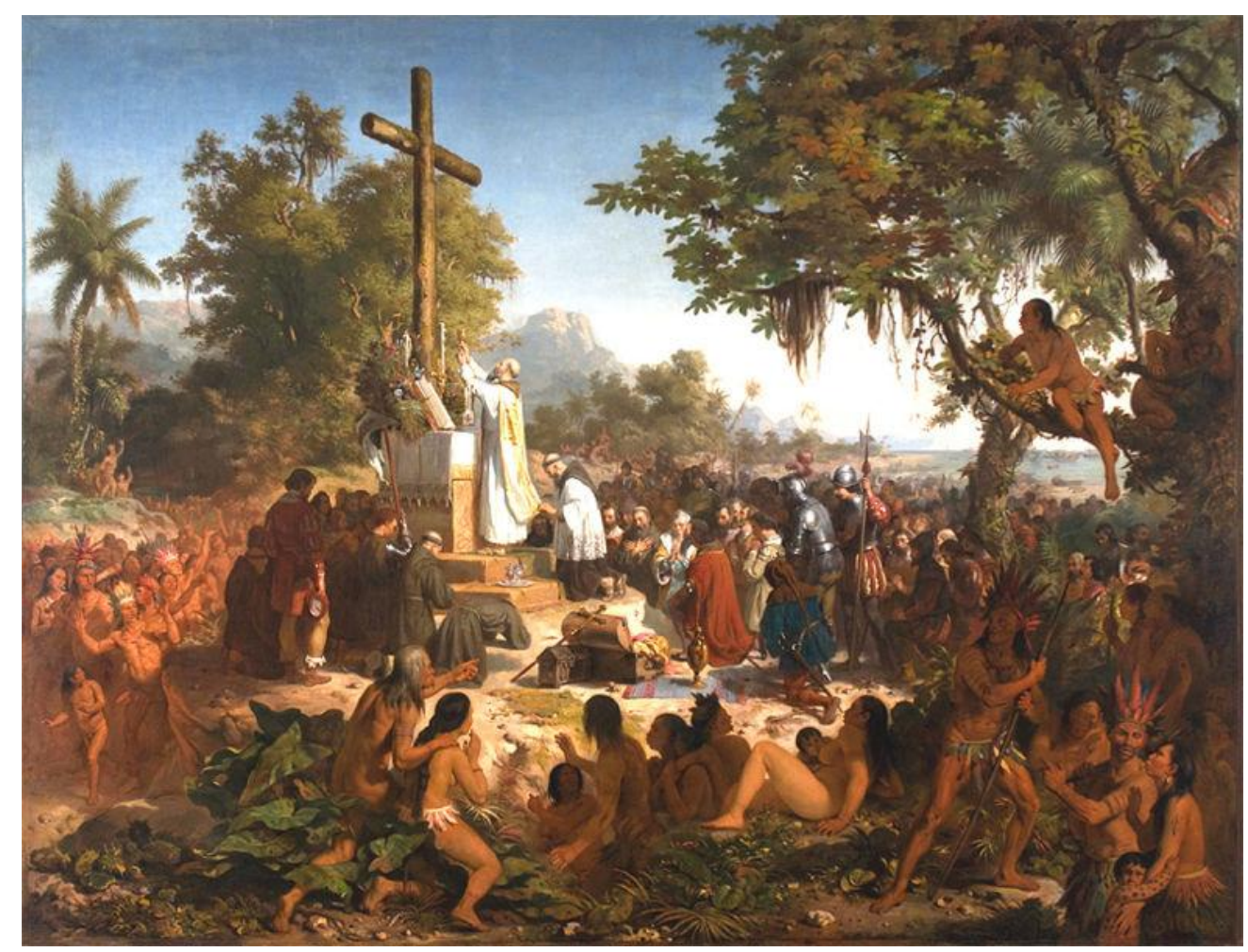

Figura 8 - Victor Meirelles, Primeira missa no Brasil, 1860, óleo sobre tela, $268 \times 356 \mathrm{~cm}$, acervo do Museu Nacional de Belas Artes / IBRAM / MinC, Rio de Janeiro. Retirado de http://www.historiabrasileira.com/brasil-pre-colonial/primeira-missa-no-brasil// Acesso em 20/11/2012. 
Em 1881, Firmino Monteiro concluiu a Fundação da Cidade do Rio de Janeiro (figura 9), que se encontra no Palácio Pedro Ernesto, sede da Câmara Municipal do Rio de Janeiro. Em 1900, Benedito Calixto pintou Fundação de São Vicente ${ }^{63}$ (figura10), obra pertencente ao Museu Paulista, e, vinte e dois anos depois, recuperou o tema com Fundação de Santos (figura11), tela central do painel da Bolsa do Café em Santos. Theodoro Braga, em 1908, terminou a Fundação da cidade de Belém ${ }^{64}$ (figura 12), que hoje pertence ao Museu de Arte da capital paraense. Em 1909, Antônio Parreiras pintou a Fundação de Niterói ${ }^{65}$, e quinze anos depois, um tríptico sobre a História do Rio de Janeiro, no qual se encontra a tela Fundação da cidade do Rio de Janeiro ${ }^{66}$.

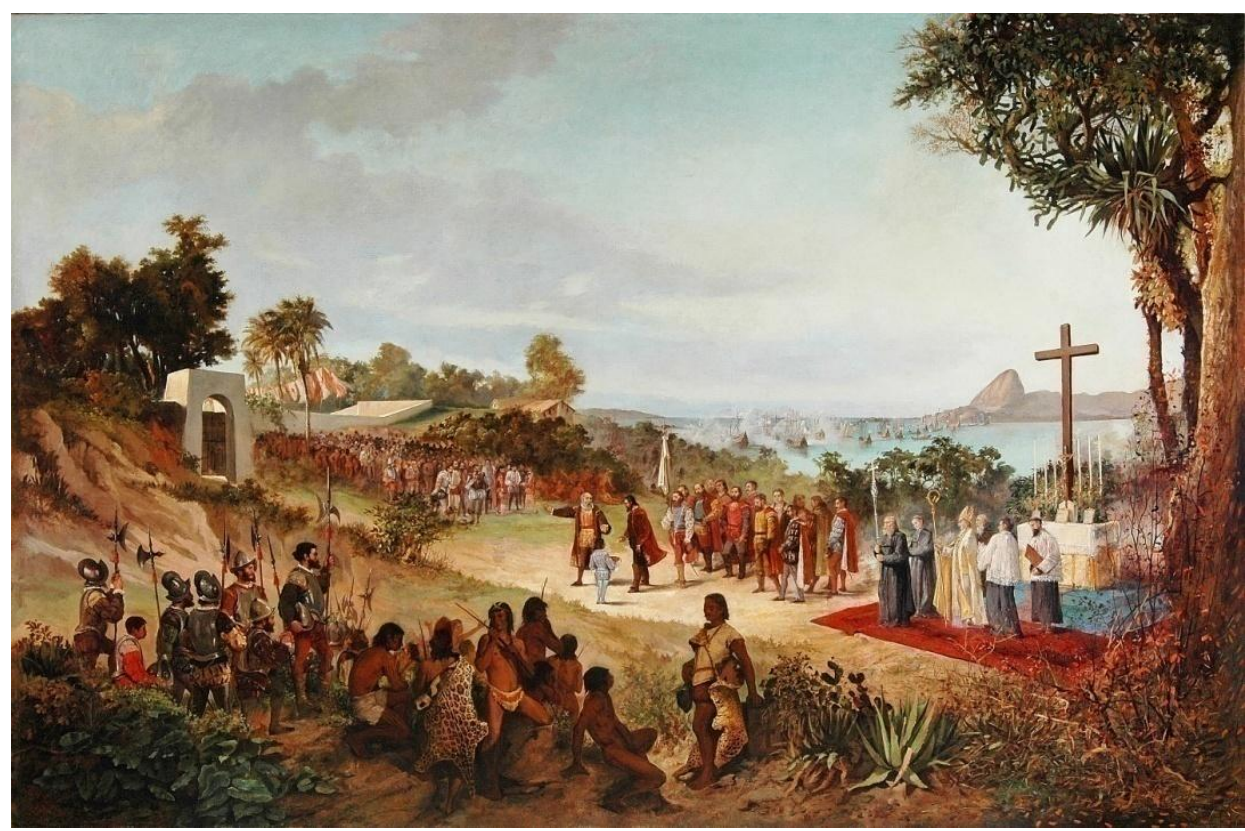

Figura 9 - Monteiro, Firmino. Fundação da Cidade do Rio de Janeiro, 1881. Foto do Acervo do Museu Paulista da USP.

\footnotetext{
${ }^{63}$ Para mais informações sobre a tela Fundação de São Vicente, ver MENESES, Ulpiano Bezerra de. Benedito Calixto como documento: sugestões para uma releitura histórica. In SALA, Dalton (org) Benedito Calixto: memória paulista. São Paulo: Pinacoteca do Estado, 1990, p. 45; ALVES, CalebFaria. Benedito Calixto e a construção do imaginário republicano. Bauru: Edusc, 2003.

${ }^{64}$ Para mais informações sobre a tela Fundação da cidade de Belém, ver PREFEITURA MUNICIPAL DE BELÉM A Fundação da Cidade de Belém. Belém: Museu de Arte de Belém, 2004.

${ }^{65}$ São escassas as informações sobre essa tela. O próprio artista a cita, em seu livro biográfico, dizendo que ele havia regressado à França "para executar três quadros históricos, Fundação de São Paulo, Instituição da Câmara Municipal para a prefeitura de São Paulo e Fundação de Niterói, para a prefeitura de Niterói." PARREIRAS, Antonio. Historia de um pintor contada por ele mesmo. Niterói: Diário Oficial, 1943 , p. 103. Porém, não foram encontrados estudos que analisassem tal obra. Nem mesmo no livro de Carlos Roberto Maciel Levy foram encontradas informações sobre ela.

${ }^{66}$ A tela foi encomendada pelo prefeito Pedro Ernesto e concluída em 1934. Para mais informações ver LEVY, Carlos Roberto Maciel. Antonio Parreiras(1860-1937): pintor de paisagem, gênero e história. Rio de Janeiro: Pinakotheke, 1981.
} 


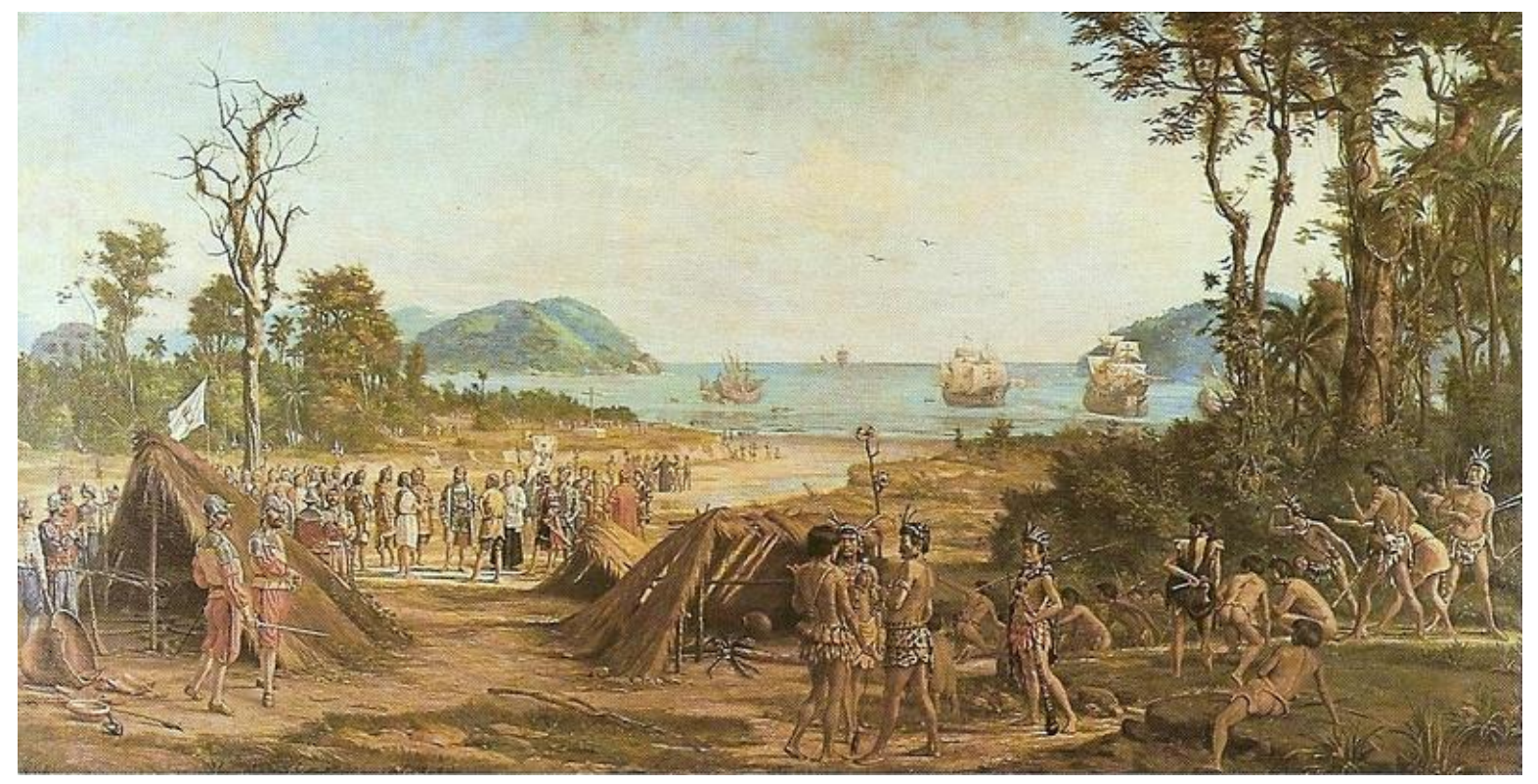

Figura 10- Benedito Calixto, Fundação de São Vicente, 1900, óleo sobre tela, 192 x 385 cm, acervo do Museu Paulista da USP, São Paulo.Reprodução fotográfica José Rosael e Hélio Nobre.

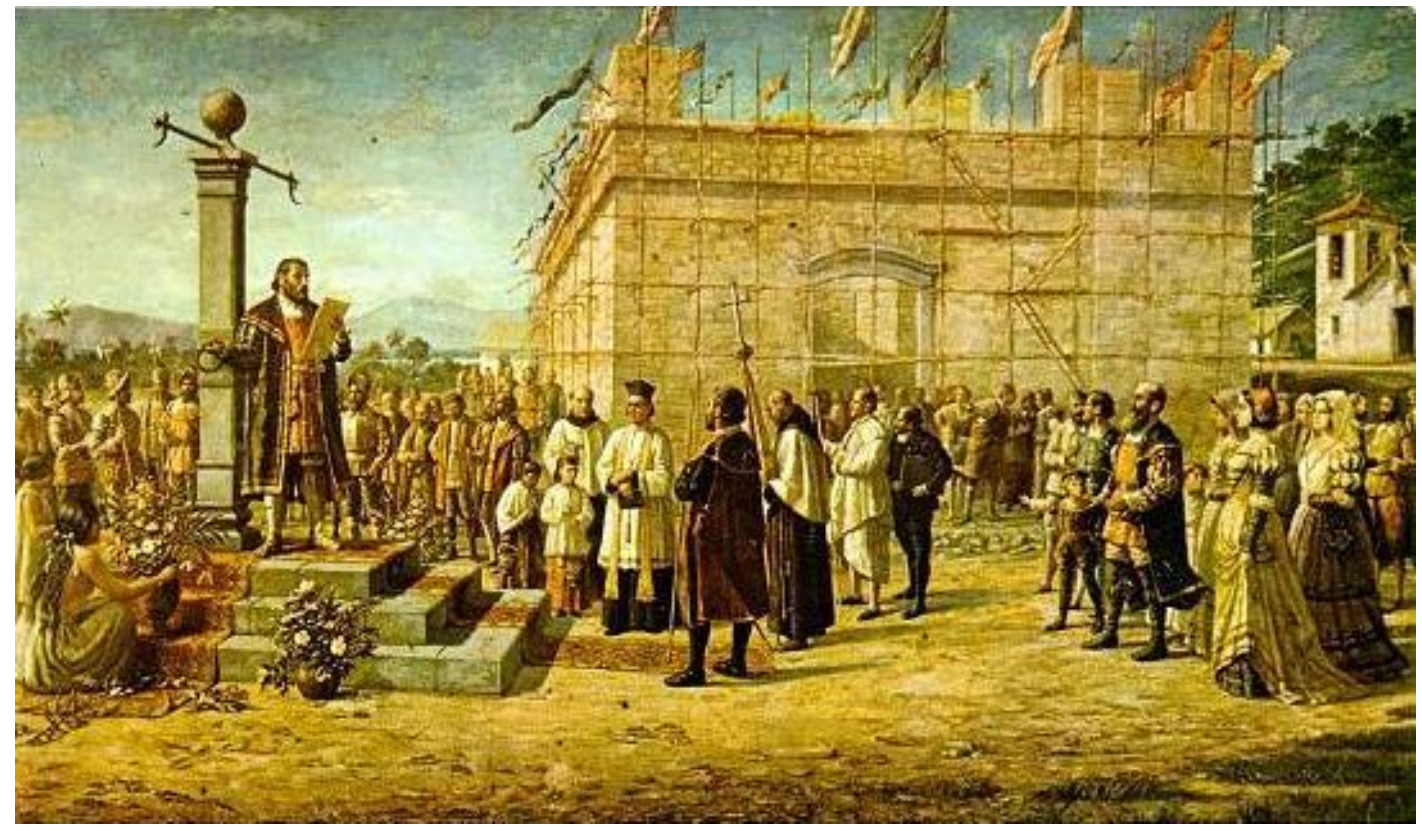

Figura 11 - Benedito Calixto, Fundação de Santos, 1902, óleo sobre tela, acervo da Bolsa do Café, Santos. Retirado de http://pt.wikipedia.org/wiki/Ficheiro:Funda\%C3\%A7\%C3\%A30 de Santos.jpg Acesso em 20/11/2012. 


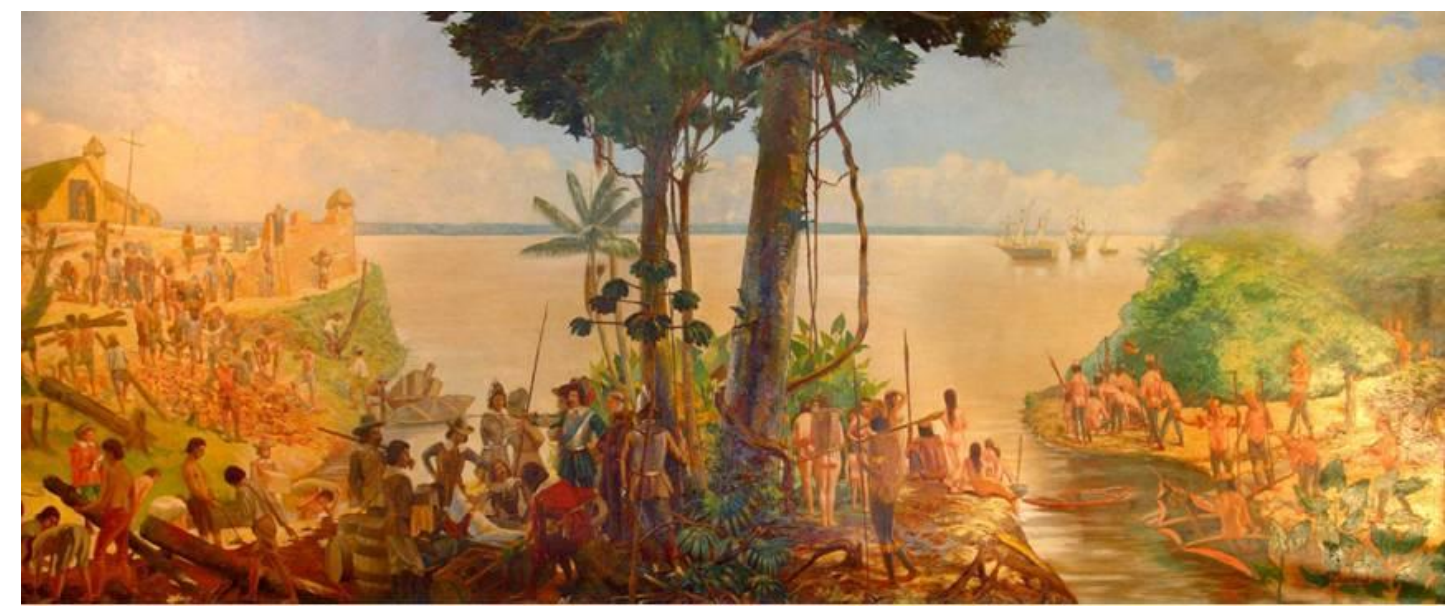

Figura 12 - Theodoro Braga, Fundação de Belém, 1908, óleo sobre tela, acervo do Museu de Arte de Belém, Belém. Retirado de http://pelasruasdebelem.zip.net/arch2011-01-01 2011-01-31.html Acesso em 20/11/2012.

Até 1907, a fundação de São Paulo ainda não havia sido tema de um quadro de grandes proporções ${ }^{67}$, como propôs Oscar Pereira da Silva. Esse era, certamente, um tema de interesse às elites dirigentes paulistas, não só pela grandeza do momento histórico a ser figurado, como pelo ineditismo da sua representação. Após quase um ano desde a primeira notícia sobre a tela ${ }^{68}$, ela finalmente ficou pronta em dezembro de 1907, medindo 185 × $340 \mathrm{~cm}$ (figura 13). A fundação do espaço urbano foi retratada, sob inspiração da tela fundamental de Victor Meirelles, por meio do contato entre índios e brancos, sob a égide da Igreja católica.

\footnotetext{
${ }^{67}$ Não se tem conhecimento de outro artista que tenha se dedicado ao tema da fundação de São Paulo antes de Oscar Pereira da Silva. Na época, quando o quadro ficou pronto, isso foi dito na imprensa, como na notícia de 31 de dezembro de 1907 do Correio Paulistano, em que o articulista escreve: "Que o saibamos, ninguém até agora se atreveu a tratar da fundação de São Paulo do modo por que o fez o pincel de Oscar".

${ }^{68}$ Durante as pesquisas, não foi possível identificar com precisão quando o quadro começou a ser feito. A notícia mais antiga que se refere à tela encontrada foi a de 22 de janeiro de 1907, citada no início do capítulo. Há, no entanto, um artigo escrito pelo jornal Correio Paulistano em 04 de agosto de 1909 que diz que o artista demorou cerca de dois anos para a elaboração da obra. Durante a exposição sobre o artista que ocorreu em 2006 na Pinacoteca do Estado de São Paulo, foi apresentado um esboço do quadro, que até 2007 pertencia a Maria Odette e Marcus Arruda, conforme informação disponível na exposição Imagens recriam a História, do Museu Paulista. Há, no entanto, um problema na atribuição desse esboço, devido ao lapso de datação entre ele - 1903 - e a tela, que é muito maior do que o estimado para a realização do quadro.
} 


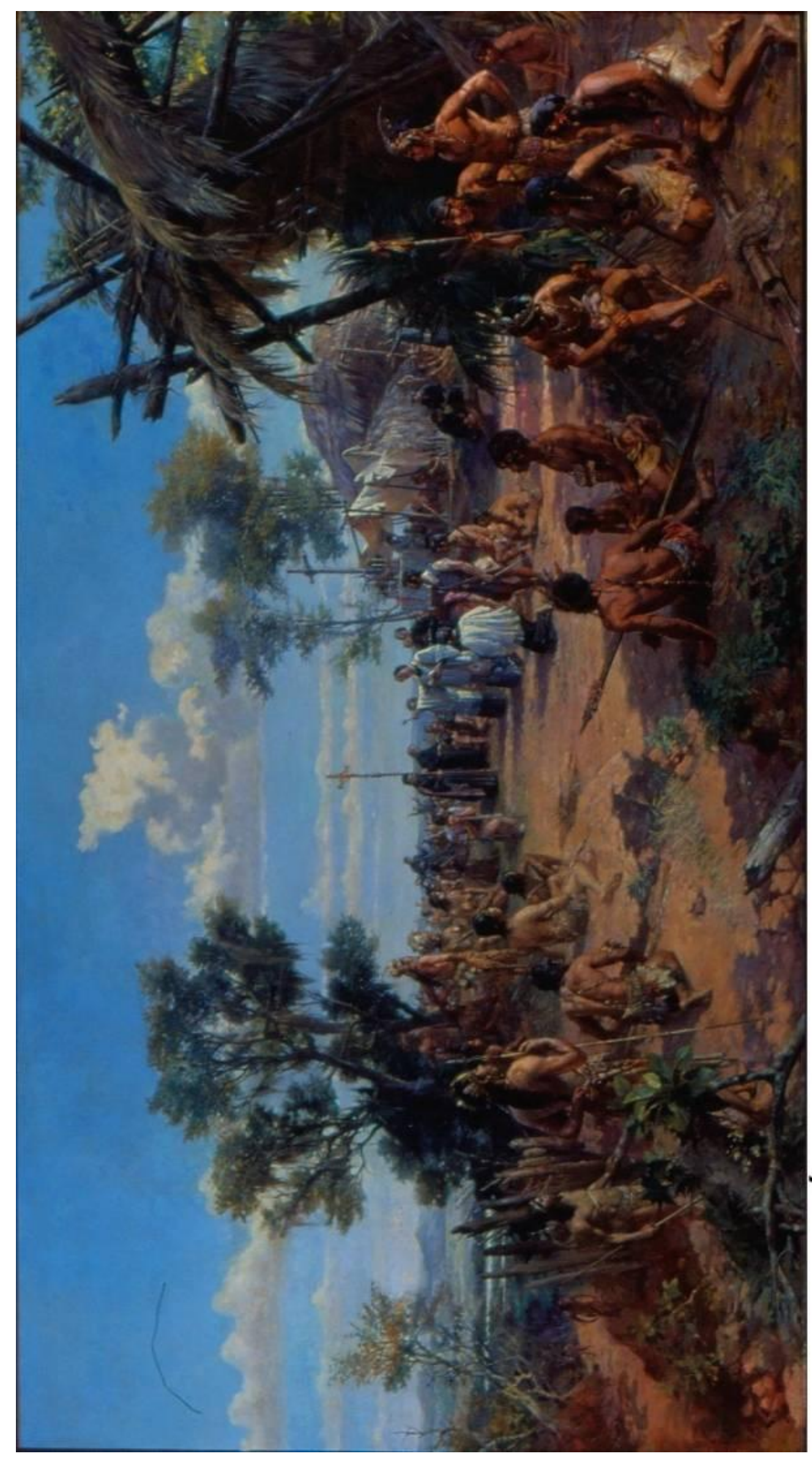




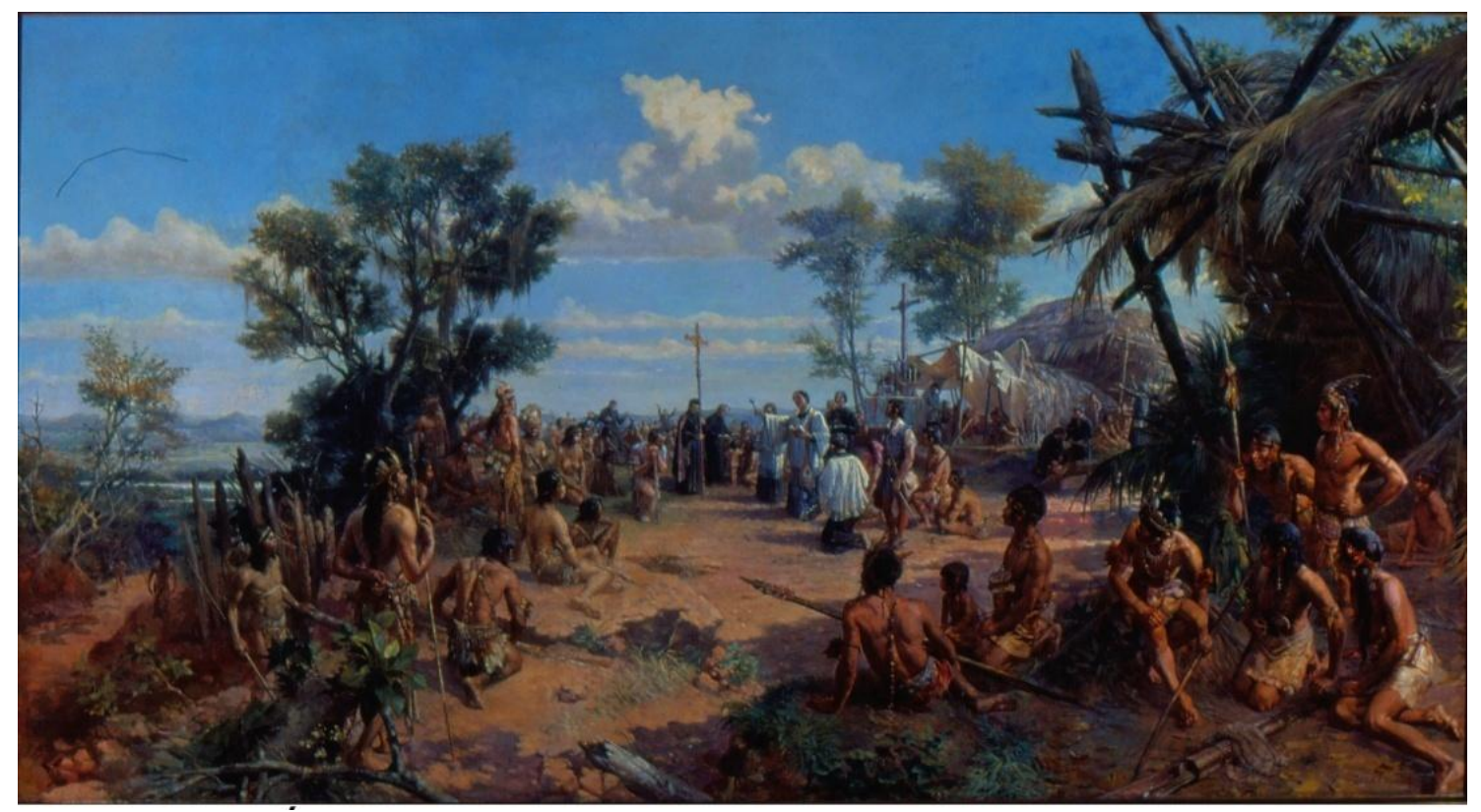

Figura 13 - Oscar Pereira da Silva, Fundação de São Paulo, 1907, óleo sobre tela, 185 x 340 cm, acervo do Museu Paulista da USP, São Paulo. Reprodução fotográfica José Rosael e Hélio Nobre.

É importante destacar que tais pinturas histórica seriam entendidas como "janela para o passado", pretendendo ser mesmo um documento do evento que nela está representado. Por tal caráter intencional, discursivo e pedagógico, as telas histórias são fonte preciosa de informações para reconstruir e entender o imaginário de sua época, ou seja, do momento em que foi produzida e consumida. Ela constitui um importante documento das experiências simbólicas vividas pelo artista e pela sociedade em se insere ${ }^{69}$. A Fundação de São Paulo apresenta aos olhos o surgimento de uma cidade no qual a arquitetura não é uma figuração de destaque; a cidade nascente é, sobretudo, a imagem de um contato entre povos mediado pela fé. Ao dar visualidade privilegiada ao tema do contato, Ihe atribuiu possibilidades de uma nova dimensão semântica que desliza do tempo figurado para o tempo de realização da própria tela.

O contato era, sem dúvida, uma experiência central na cidade e no estado de São Paulo nessa primeira década do século XX. Novos contatos eram impostos aos velhos paulistas, de pronto, pelo grande afluxo de estrangeiros que São Paulo recebia. A imigração substituíra o braço escravo na lavoura e, na passagem do século XIX para o XX, dava-se com grande intensidade. Mas para além dessa experiência de contato por si só gigantesco, havia também o contato estabelecido com os índios em

\footnotetext{
69 MENESES, Ulpiano T. Bezerra de (org.). Como explorar um museu histórico. São Paulo: Museu Paulista/USP, 1992, 24. BREFE, Ana Claudia Fonseca. Museu Paulista, Affonso de Taunay e a memória nacional (1917 - 1945). São Paulo: Editora Unesp; Museu Paulista $2 n \cap 5$ n $\Delta 1-\Delta$ ?
} 
decorrência das novas frentes de expansão do café e das ferrovias em direção ao rio Paraná. A penetração dos territórios indígenas por "agentes da civilização" tomou vulto maior, tanto em relação à sua profundeza como ao seu volume, durante os primeiros anos da República:

A ocupação mais intensa das terras, habitadas por índios, ao sul da região amazônica, deu-se em São Paulo e no norte do Paraná, depois de que a fronteira cafeeira se livrou dos efeitos temporariamente estropiantes da abolição e da consequente confusão geral, para recomeçar, na década de 1890, sua dinâmica marcha para Oeste. Com isto se deu um assalto em grande escala às terras indígenas. Milhares de brasileiros estavam na vanguarda da marcha, a qual dependia largamente de imigrantes italianos para o fornecimento de mão-de-obra. Abrindo seu caminho através dos vales arborizados dos rios Mogi Guaçú e Pardo, eles estenderam suas plantações para dentro do território indígena hostil do rio Tietê, onde a construção da Estrada de Ferro Noroeste estava encontrando feroz resistência. Seguindo seu caminho até o rio Paranapanema e, no sudoeste, atravessando a fronteira São Paulo-Paraná, a onda verde dos cafeeiros avançou inexoravelmente. (...) Por volta de 1908, o avanço das plantações de café, através da floresta virgem e da savana, tinha-se tornado mais impetuoso que nunca ${ }^{70}$.

Quando Oscar Pereira da Silva decide realizar Fundação de São Paulo, figurando a gênese da cidade e do povo paulista, novas gêneses estavam, portanto, em curso. A origem do povo que se pretendia propulsor da nação, a partir de da então mais galopante cidade brasileira, era retomada na tela à óleo por meio da evocação do contato estabelecido entre europeus e índios, permeados pela igreja católica. Esta não era, por certo, uma proposta visual inovadora, uma vez que Victor Meirelles havia se utilizado desta mesma tópica quase cinqüenta anos antes para representar a origem da nação brasileira. Os paralelos imagéticos entre a Fundação de São Paulo e a Primeira missa no Brasil são evidentes, não só por seguirem o mesmo modelo temático do encontro, como pela óbvia semelhança no modelo compositivo e na distribuição dos elementos na tela.

Vale destacar que a referência a outros artistas era uma prática não só muito recorrente como nobilitante, constituindo-se como um instrumento legítimo à natureza do gênero de pintura histórica. Os alunos da Academia aprendiam por meio de cópias de modelos, que eram apresentados como normas de excelência e bom gosto. A citação, portanto, não era encarada como falta de imaginação ou plágio, ao contrário, demonstrava a capacidade técnica e artística do pintor, que tinha aptidão para retomar

\footnotetext{
70 STAUFFER, David Hall. "Origem e Fundação do Serviço de Proteção aos Índios (1889-1910)" trad. de J. Philipson. Revista de História, USP, São Paulo, no. 42, 1960, p. 443.
} 
um elemento preexistente e inseri-lo em um novo contexto. A inovação e a especificidade do fazer não eram tidos como valores fundamentais, pois o que importava era dar conta de um programa ambicioso ${ }^{71}$.

É possível notar a recorrência da prática da citação na própria obra Primeira missa no Brasil. Assim como Oscar Pereira da Silva se inspirou em Victor Meirelles, esse havia tomado como referência a obra LaPremière messe em Kabylie ${ }^{72}$ (figura14), de HoraceVernet ${ }^{73}$, pintada em 1854 e apresentada em 1855 no Salon, de Paris. O episódio narrado por Vernet havia ocorrido em 1853 e no âmbito do projeto colonial francês na África do Norte. A missa celebrava a submissão das tribos cabilas e simbolizava o domínio do exército conquistador sobre um povo que havia resistido ao avanço europeu. $\mathrm{O}$ artista participou da campanha, pois fora o cenógrafo do evento. A tela era, portanto, uma reconstrução simbólica de autoria do próprio Vernet, que transpôs para imagem fictícia da tela o que deveria se constituir como "verdade" daquele evento.

A relação entre oseventos históricos retratado por Meirelles e Vernet, a despeito da enorme distância temporal entre ambos, possuía pontos em comum, já que era uma celebração religiosa, que unia "infiéis" e europeus. O fato do artista francês ter sido testemunha ocular do acontecimento era algo que lhe atribuía a legitimidade e a veracidade, aspectos que Meireles certamente ansiava para embasar sua composição sobre a missa na costa brasílica.

\footnotetext{
${ }^{71} \mathrm{COLI}$, Jorge. Como estudar a arte brasileira do século XIX?.São Paulo: Editora Senac, 2005, p. 14-16.

72 Horace Vernet, La première messe en Kabylie, oleo sobre tela, 194 x 123 cm, 1854, Musée Cantonal des Beaux-Arts, Lausanne.

${ }^{73}$ Foi Jorge Coli que identificou esta nítida referência entre a Primeira Missa no Brasil, de Victor Meirelles, e a La Première messe enKabylie de HoraceVernet. É possível consultar a análise comparação completa dessas obras em: COLI, Jorge. Como estudar a arte brasileira do século XIX?.São Paulo: Editora Senac, 2005, p. 32.
} 


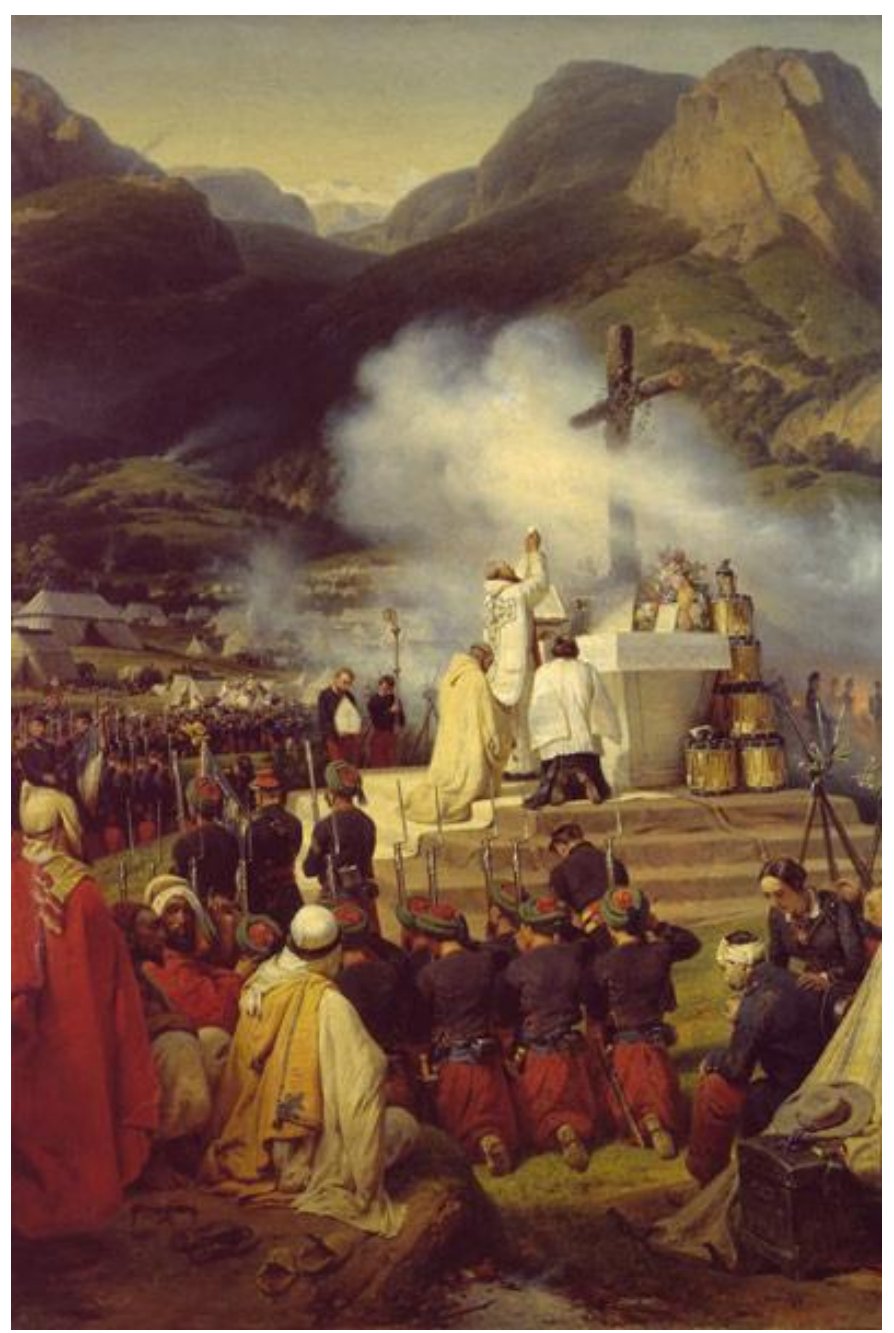

Figura 14 - Horace Vernet, Première messe en Kabylie, 1854, óleo sobre tela, 194 x 123 cm, acervo do Musée Cantonal des Beaux Arts, Lausanne.

As semelhanças compositivas da Primeira missa no Brasil e La Première messe em Kabylie são evidentes, como apontou Jorge Coli. O grupo central é o mesmo, disposto de modo invertido; há um altar montado, com uma grande cruz de madeira, em cuja base se encontram plantas típica, que a envolvem. $O$ momento retratado é exatamente o mesmo: a consagração da Eucaristia. Nota-se, nas duas representações, frades ajoelhados ao pé da cruz e, em Meirelles, esse movimento forma um leque até atingir a posição horizontal ao solo. A cena central está circundada por uma enorme orla espectadores, composta de nativos e europeus, que assistem a celebração. Há inclusive a presença de pessoas armadas, mais evidentes em Vernet, pois são em maior número.

É importante destacar que a Primeira missa no Brasil foi a primeira obra de um pintor brasileiro a ser apresentada no Salon parisiense, fato que ocorreu em 1861 e acentuou a importância do quadro, tornado-o muito conhecido no Brasil. Esse era, 
portanto, um ótimo modelo ${ }^{74}$ a ser seguido por Oscar Pereira da Silva, que obviamente se inspirou na obra de Meirelles para compor um quadro que alicerçasse no passado o contexto de consolidação da hegemonia paulista no âmbito da política nacional republicana.

Essa não havia sido a primeira tela em que Oscar Pereira da Silva se inspirara numa estrutura compositiva proposta pelo mestre da AIBA. A tela com a qual venceu 0 concurso de 1887 e garantiu a sua estadia em Paris, havia se baseado em outra obra de Victor Meirelles, a Flagelação de Cristo, realizada em 1856. Em 1907, Oscar Pereira da Silva decidiu manter sua inspiração e apostar no modelo que outrora havia Ihe consagrado.

A semelhança entre as telas dos pintores brasileiros é, por exemplo, muito visível na disposição formal dos elementos. O ato religioso está no centro do quadro e é ressaltado tanto pelo desnível, que o coloca acima das demais figuras das obras, quanto pela iluminação, que incide diretamente na ação dos padres e conduz, assim, o olhar do espectador. A cruz, em Oscar Pereira da Silva encontra-se exatamente ao centro e divide o quadro em duas porções simétricas. Enquanto na obra Meirelles, a cruz pende para a esquerda, porém sua grandiosidade torna-a um elemento de destaque. Percebemos que a ação religiosa desenvolvida são distintas, pois uma retrata a consagração da Eucaristia durante a missa, enquanto a outra é o momento em que o padre benze o local onde será erguida, posteriormente, a cidade de São Paulo. Essa diferença tem uma implicação evidente: na primeira, o padre encontra-se apartado e de costas para os índios, já que reza a missa. Enquanto na segunda, a própria ação dos missionários permite uma maior integração entre as duas culturas que se convergem e se unem.

Em ambas as telas, o ato religioso é envolvido por uma força centrípeta que dispõe todos os elementos em torno dele. Existe uma massa de espectadores em forma de guirlanda, que na Primeira missa é significativamente maior e mais coeso que na Fundação. Naquela, a disposição dos personagens que, embora guardem o princípio de unidades grupais, reúnem os participantes numa fusão, que inclui também a natureza, e da qual é difícil distinguir a individualidade de cada índio, já que Meirelles trata os indígenas de maneira pouco descritiva. Já em Oscar Pereira da Silva, apesar de existir uma massa fundida de indígenas ao fundo da tela, aqueles que estão mais próximos do espectador estão esparsos, por isso, são mais individualizados, tanto que

\footnotetext{
${ }^{74}$ A pesquisa buscou outras imagens que possam ter sido referência a Oscar Pereira da Silva, sobretudo durante sua passagem em Paris, porém, não foram encontradas telas que pudessem ser claramente apontadas como modelo ao artista, a não ser as que aqui foram indicadas.
} 
é possível notar os corpos bem delineados, os adornos que eles utilizam, os instrumentos que carregam e até a feição de cada um.

As figuras que compõe essa orla de espectadores, em ambas as telas, são compostas por homens, mulheres e crianças, que integram a cerimônia, porém sem exercerem um papel ativo. Apenas seguem o que lhes é imposto, sem qualquer sinal de resistência na ação, o que é muito visível na disposição dos corpos e na função que desempenham ao povo que ali está sendo gestado. O olhar dos nativos é atento e em Meirelles eles inclusive tecem comentários uns aos outros sobre o evento inusitado do qual participam. Interessante perceber as crianças que ali também estão presentes, algumas em pose muito semelhante nos dois quadros, como a que apóia em sua mãe. A diferença é que em Oscar Pereira da Silva elas também estão entretidas com o acontecimento, já em Meireles elas estão distraídas, como a do canto inferior direito, que até olha para o espectador.

A passividade dos nativos é visível também pelos espaços que ocupam nas telas - os mais escuros e periféricos. Nos dois quadros existe a figura do chefe indígena, que é o único que está em uma posição que não é de completa submissão. Em Meireles, ele aparece no canto inferior direito, já em Pereira da Silva, ele está na porção central à esquerda. Apesar da pose um pouco mais resistente, nenhum deles é facilmente notado pelo observador, pois não há um destaque para essas figuras, que se confundem com os demais indígenas. Interessante perceber como o evento exerce uma força de atração, que conduz muitos nativos a participarem daquele acontecimento. Na Primeira missa há uma certa sutileza, pois esses índios estão em proporção menor, na parte esquerda da tela. Já na Fundação isso é bem evidente, pois eles são atraídos e, por isso, sobem o caminho de terra à esquerda para participarem da cena. Nos dois casos, esses índios que se aproximam foram pintados de maneira mais despojada, não estando tão bem delineados se comparados aos demais. Os nativos demonstram interesse pela religião, e parecem entendê-la naturalmente. Essa evidência, em Oscar Pereira da Silva, é demonstrada não apenas pela atitude passiva, como também pela posição dos corpos dos índios, já que alguns até se ajoelham diante da cruz. Em Meirelles, entretanto, eles são mais "animalizados", pois alguns estão pendurados na árvore, outros estão completamente nus, e há, inclusive, uma índia amamentando seu filho durante a missa.

Contribuindo para essa força centrípeta em torno da cena principal, está também a natureza, que emoldura os dois quadros e desempenha um papel de grande importância, pois ela substitui o templo, já que a cerimônia acontece ao ar livre. 
Ela não ideal e arcádica, mas descritiva e nacional ${ }^{75}$. Além disso, há muitos paralelos nos elementos constituintes dessa natureza nas duas imagens. Os dois pintores colocaram uma pequena árvore isolada à esquerda, seguida de uma massa arbórea mais ao centro, há também ramos na parte inferior da tela e uma grande árvore à direita, único elemento que Oscar Pereira da Silva modifica ao substituir por uma estrutura de madeira e folhagens. Em ambas as telas existe também uma referência hidrográfica, o mar no terceiro plano à direita, em Meirelles, e a o rio Tamanduateí no terceiro plano à esquerda, em Oscar Pereira da Silva. A posição dos dois quadros é horizontal, porém isso é mais acentuado na Fundação de São Paulo, o que atribui um destaque maior ao local em que se desenrola o evento retratado.

Diante dos paralelismos demonstrados entre as duas telas, é possível afirmar que ocorreu uma evidente transição do modelo da AIBA para um novo contexto. A obra de Pereira da Silva pretendia ser a versão paulista para a aurora da nação, reinaugurando um marco estabelecido décadas antes por Meirelles, porém destacando o protagonismo de São Paulo na história nacional e estabelecendo simbolicamente que o início da nação teria se dado em solo paulista, e por meio da fundação da missão que viria a se tornar a cidade de São Paulo. A inconstância e precariedade daquele missa na beira-mar, num local que não viria de imediato a se tornar um povoado era, assim,transmutada por Oscar Pereira da Silva em algo definitivo, perene: a cidade nascente.

É fundamental entender essa imagem como uma representação, conceito proposto por Roger Chartier ${ }^{76}$, já que ela se constitui como matriz de discursos e de práticas que têm por objetivo a construção do mundo social e a definição das identidades. Portanto, investigar representações permite reconhecer os mecanismos de disputa ideológica. Diante disso, é imprescindível deter atenção à composição formal da obra, a fim de compreender os elementos que a compõe e como essa elaboração plástica contribuiu para a construção da identidade paulista.

O método aqui utilizado para a análise formal do quadro é o proposto por Meneses ${ }^{77}$ que, ao analisar a obra Fundação de São Vicente, de Benedito Calixto, indicou três aspectos fundamentais a serem abordados. Em primeiro lugar, a extensão

\footnotetext{
75 Segundo Jorge Coli, Araújo Porto Alegre haveria aconselhado Meirelles a construir uma natureza tipicamente nacional, sugestão foi posta em prática na Primeira missa no Brasil. VER COLI, Jorge. Como estudar a arte brasileira do século XIX?.São Paulo: Editora Senac, 2005, p. 30-31.

${ }^{76}$ CHARTIER, Roger. O mundo como representação. In: Estudos Avançados. São Paulo, n.11(5), p.173191, 1991.

${ }^{77}$ MENESES, Ulpiano T. Bezerra de. Benedito Calixto como documento: sugestões para uma releitura histórica. In: D. Sala. (Org.). Benedito Calixto: memória paulista. São Paulo: Pinacoteca do Estado, 1990,, p. $37-47$
} 
que ocupa a tela, o seu enquadramento e a disposição geral dos componentes representados. Em seguida, como está estruturada a paisagem, o papel que exerce na composição e quais são os elementos distintivos do local. Por fim, a distribuição das figuras, a hierarquia proposta e os suportes de atividade humana.

Na tela de Oscar Pereira da Silva, Fundação de São Paulo o corte não é aleatório, tudo está contido na tela e disposto de maneira organizada e equilibrada. $O$ espaço é visivelmente hierarquizado, pois há um desnível, que coloca a cena central em posição mais elevada e com maior destaque. Esse é um desnível real, imposto pela topografia do local; porém é também simbólico, por isso a cruz ocupa local ainda mais elevado e a disposição das figuras se organizam a partir dela. Ao dividir a tela em quatro quadrantes, é possível verificar a centralidade da cena principal, que é reforçada não só pela iluminação intensa, que incide nessa porção do quadro, quanto pelo caminho de terra e o espaço vazio em forma triangular que conduz o olhar do espectador à ação que ali se desenrola. O triângulo serve também para dividir, proporcionalmente, dois grupos de índios que estão no primeiro plano da tela. A horizontalidade do quadro enfatiza o espaço em que se desenvolve a ação.

A paisagem não exerce função demarcatória, já que o único elemento que sugere alguma identificação do local é o rio Tamanduateí que, no entanto, ocupa uma posição em terceiro plano,no fundo da tela. A natureza não oferece perigo, ao contrário, ela aparece contida, servindo de cenário, que envolve a cena principal. Substituindo esculturas e edifícios, as árvores constituem um monumento natural, que fornece uma grandiosidade à cena. As duas cruzes de maior destaque estão envoltas por elementos naturais que as emolduram: a da direta, envolvida por árvores e a da esquerda pelas nuvens, que the atribuem um caráter celestial e sagrado, de transcendência. A natureza compõe também as primeiras sugestões de edificações: a choupana dos índios, à direita da tela, em primeiro plano, que é feita com uma estrutura de madeira e folhagens; e a vivenda, que serve de Igreja, feita de madeira, palha e tecido. Estão, assim, justapostos o espaço dos nativos e o dos europeus. Outra função desempenhada pela natureza é justamente como subsidiária da união entre índios e europeus, o que é evidente no caminho de terra, que estabelece uma ligação entre a natureza, que está ao longe e ainda não sofreu alterações pela ação do homem, com a cena central, que representa o estabelecimento da civilização. É por meio desse o caminho que os índios chegam ao local em que está sendo realizada a missa e onde seria erigida a igreja que daria origem à cidade, dessa maneira, eles são conduzidos à "civilização". Em artigos ${ }^{78}$ de jornais contemporâneos ao quadro, foi dito,

\footnotetext{
${ }^{78}$ Correio Paulistano, 04 de agosto de 1909.
} 
inclusive que este era o caminho velho do mar, transformado, posteriormente, em rua do Carmo, embora seu traçado coincida mais com a atual rua General Carneiro. Com este comentário, é possível perceber a estreita relação entre a tela o espaço urbano e, conclui-se, que a incipiente cidade já está evidenciada.

As figuras que compõe a obra são formadas por nativos, europeus e religiosos, que estão harmoniosamente integrados. A conotação demográfica é muito evidente, já que se nota a presença de homens, mulheres e crianças. Há, entretanto, uma nítida hierarquização das personagens, que é observado, primeiro, pela posição que ocupam no quadro: os europeus ao centro, em nível elevado; enquanto os índios encontram-se na parte periférica, envolvendo a cena central junto à natureza. Os indígenas ocupam as porções menos iluminadas da tela, enquanto os europeus são destacados pela luz. A posição dos corpos também indica a diferenciação: europeus eretos ou ajoelhados apresentam posição altiva, enquanto os indígenas encontram-se em poses mais despojadas, e à medida que se aproximam da cruz, têm seus corpos curvados ou sentado, em posição de contemplação e submissão. A atuação das figuras é também desigual, pois a atividade está concentrada nas ações dos europeus, enquanto os índios são marcados por uma atitude de passividade, como se reconhecessem pacificamente e naturalmente a religião.

O momento retratado é o logo após a missa rezada em 25 de janeiro de 1554, quando o padre Manuel da Nóbrega, ladeado por Manuel Paiva e Anchieta, benze o lugar em que seria edificada uma Igreja, a partir da qual, posteriormente, prosperaria a vila e depois cidade de São Paulo. Importante notar que a bênção não é apenas do espaço físico, mas também dos índios. Isso é muito evidente na criança indígena que está sendo atendida por um missionário, já que ela se encontra exatamente interposta entre a cruz central e o padre que celebra o ato. Os índios estão, portanto, sendo iniciados na religião e na civilização. O papel da Igreja não é apenas abençoar o local onde seria construída cidade, mas também o povo que dali se originará e terá um papel de grande relevância para o progresso da nação brasileira. Essa nova "raça" é constituída do elemento europeu e do nativo cristianizado. Afora à cena central, existem algumas secundárias e periféricas, que retratam o convício harmonioso entre religiosos e indígenas. 


\section{A cidade que nasce da submissão}

A obra de Oscar Pereira da Silva propõe, como foi demonstrado, que o contato entre nativos e europeus, mediado pela fé civilizadora, teria ocorrido por meio da fundação do espaço urbano. É importante perceber que essa representação foi composta de escolhas feitas pelo artista e que teriam uma evidente implicação nos destinos da obra, que devia, sobretudo, se constituir como "janela do passado", ou seja, ser a verdade do evento nelas retratado. Para tanto, era fundamental, em primeiro lugar, basear-se em convenções pictóricas. A paridade entre Primeira missa no Brasil e Fundação de São Paulo demonstra claramente as escolhas picturais do artista: seguir o modelo clássico e consagrado da AIBA, instituição da qual era filiado. Neste aspecto, portanto, a opção feita por Oscar Pereira da Silva foi muito assertiva, já que a estrutura compositiva baseava-se em uma referência de inquestionável valor, além de ter sido muito bem executada em termos de qualidade técnica. Não bastava, entretanto, a imaginação e a idealização baseadas em convenções pictóricas. Era imprescindível que a iniciativa artística estivesse articulada ao pensamento historiográfico, uma vez que a veracidade pretendida pela obra era medida por sua filiação documental. Logo, o quadro deveria compartilhar das ambições dos historiadores e a escolha do pintor recaiu sobre a produção do IHGSP.

Além disso, a ideia da criação da imagem da gênese de São Paulo e dos paulistas não foi uma proposta descontextualizada das tensões políticas de seu próprio tempo.É possível associar a tela às questões suscitadas pelas novas dimensões do contato, em decorrência da "marcha para oeste" e do enorme afluxo de imigrantes para o estado. Fundação de São Paulo foi produzida em um tempo em que estavam também sendo estabelecidas as bases do "mito paulista", que determinava que São Paulo e os velhos paulistas haviam sido responsáveis pela gestação da nação brasileira, capazes de difundir a civilização por todo o Brasil. O IHGSP, responsável por constituir um eixo de interpretação da história nacional a partir da história paulista, esteve, desde a sua fundação, preocupado em traçar e esclarecer questões sobre a origem da cidade e da constituição do inicial do paulista. Ao pretender reescrever a história do Brasil, contrapunha-se à corrente historiográfica consolidada pelo IHGB, inspirada em obras precursoras como as de Martius e Varnhagen. Por isso, questões como a fundação, o desenvolvimento da cidade, os 
índios e os patriarcas paulistas eram muito recorrentes na produção do IHGSP, cujos artigos, publicados em sua revista, colocavam em debate essas questões ${ }^{79}$.

Se, como propôs Jorge Coli, ${ }^{80}$ a Primeira missa no Brasil foi uma "invenção" do século XIX - pois foi nesse contexto que a carta de Caminha foi publicada e divulgada, servindo de base para a imagem criada por Victor Meirelles - a tela Fundação de São Paulo, portanto, associa-se a uma "invenção" historiográfica do século XX. Ao mesmo tempo em que historiadores se empenhavam em recuperar documentos considerados autênticos que esclarecessem as dúvidas a respeito da gênese de São Paulo, Oscar Pereira da Silva lançou-se no ambicioso projeto de dar visualidade aos escritos históricos. Não existia, entretanto, um documento que descrevesse o ato de origem, tal como a Carta de Caminha, que havia narrado a missa, o que permitia atribuir legitimidade à imagem de Victor Meirelles. Na falta de um documento como esse, era necessário ao pintor inteirar-se dos debates em torno da fundação paulistana, debate esse que está expresso em conferências e artigos que serão examinados, a fim de encontrar possíveis diálogos da obra de Oscar Pereira da Silva com a produção intelectual a ela contemporânea.

O que salta aos olhos ao se observar a tela é o papel de destaque dado à Igreja Católica no processo fundador. Afora o bom relacionamento que o artista mantinha com membros da elite católica, os vínculos desta instituição religiosa com o IHGSP eram muito sólidos. Segundo Ferreira, apesar do instituto ter abrigado diversos intelectuais positivistas e outros crentes da ciência, as inclinações menos extremadas, partidárias de um compromisso entre fé religiosa e defesa do conhecimento científico foram as prevalecentes. Difícil é, portanto, entender os campos científico e intelectual de São Paulo como autônomos em relação aos poderes do Estado e da Igreja ${ }^{81}$.

Os intelectuais católicos procuraram, em seus estudos, dar relevo ao papel da Igreja no processo civilizador. Entre os autores do IHGSP que de dedicaram aos estudos etnográficos sobre os indígenas, aparece diversas vezes o nome do

\footnotetext{
79 Segundo Ferreira, era à Revista do IHGSP, publicada anualmente, que os consócios destinavam a maior parte do seu labor. Era por meio dela que o Instituto ganhava visibilidade, já que circulava entre um público leitor limitado, porém, qualitativamente escolhido: homens eruditos e de letras em geral, políticos e burocratas em variados níveis, famílias abastadas ou de posses medianas. No período de 1895 a 1940, $12 \%$ das matérias da revista do Instituto tratavam de cidades e dioceses; $9,3 \%$ de povoamento e expansão bandeirante; $7,5 \%$ de populações indígenas - assuntos que ocupavam os segundo, terceiro e quarto lugares no ranking de freqüência de temas. Além destes, havia também descobrimento e colonização, com 3,8\% e genealogias familiares, com 2,1\%. VER FERREIRA, Antonio Celso. $A$ epopéia bandeirante: letrados, instituições, invenção histórica $(1870$ - 1940). São Paulo: Editora Unesp, 2002, p. 126.

${ }^{80} \mathrm{COLI}$, Jorge. Como estudar a arte brasileira do século XIX?.São Paulo: Editora Senac, 2005, p. 23.

81 FERREIRA, Antonio Celso. A epopéia bandeirante: letrados, instituições, invenção histórica (1870 1940). São Paulo: Editora Unesp, 2002, p.101-102.
} 
Monsenhor Camillo Passalacqua, que defendia a ação missionária dos jesuítas. Em um artigo de 1898, que trata de índios do grupo Pury, ele afirma: "a experiência tem mostrado que não é possível tratar da civilização desta gente procurando-a atrair para a povoação civilizada... O único meio é o que empregam os jesuítas... pela religião"82.

Uma figura emblemática dentre os intelectuais católicos sócios do IHGSP é Eduardo Prado ${ }^{83}$, um dos expoentes da vertente de estudiosos que valorizava as heranças lusa e católica na constituição do Estado Nacional. Em 1896, participou de uma conferência em homenagem a Anchieta, realizada na Faculdade de Direito ${ }^{84}$ de São Paulo, instituição com evidentes vínculos políticos e religiosos ${ }^{85}$. A palestra, intitulada O Catolicismo,a Companhia de Jesus e a Colonização no Novo Mundo, expõe com clareza o ponto de vista da intelectualidade católica. Segundo ele, haveria três métodos para uma "raça superior" dominar as terras habitadas por uma "raça inferior". A primeira maneira é a instintiva ou científica, que consistia na destruição dos primeiros ocupadores do solo. Outra alternativa era pelo método mercantil, em que europeus assenhoravam-se de um ou mais pontos, na costa, estabeleciam empórios e negociavam com indígenas, porém, enganando-os e desmoralizando seus maus costumes. Haveria, entretanto, um terceiro método de colonizar, chamado de católico, que pregava a fusão de raças opostas por meio do catolicismo, que soube na América ensinar, civilizar, abençoando a união fecunda das raças, das quais deveriam brotar tantas nações.

\footnotetext{
82 Revista do Instituto Histórico e Geográfico de São Paulo, 1898, v. III. Citado em FERREIRA, Antonio Celso. A epopéia bandeirante: letrados, instituições, invenção histórica (1870 - 1940). São Paulo: Editora Unesp, 2002, p.139.

${ }^{83}$ Vale lembrar que Oscar Pereira da Silva realizou alguns trabalhos para a família Prado. Como os já citados retratos de Martinho Prado e Albertina Prado, além do quadro Uvas da chácara de dona Veridiana, Posteriormente, seria requisitado por Antonio da Silva Prado Junior para restaurar a tela Aurora, realizado por Almeida Júnior e também fazer o quadro Poesia, como está descrito na notícia de 29 de setembro de 1916 do jornal O Estado de São Paulo.

${ }^{84}$ Segundo Lilia Schwarcz, com a independência política em 1822, tornou-se necessária a formação de uma elite capaz de orientar os rumos da nação. Para tanto, em 1828, foi fundada a Faculdade de Direito de São Paulo, instalada no convento de São Francisco. Essa instituição constitui-se em um dos centros intelectuais do país, com uma produção que extrapolava os limites da cultura jurídica, pois reunia a militância política, o jornalismo a advocacia e, sobretudo, a ação no interior dos gabinetes. A Academia não só tendeu a legitimar a vigência de um Estado autoritário e claramente manipulador, como procurou na teoria evolucionista a certeza de sua origem e de um futuro certo. Ver SCHWARCZ, Lilia Moritz.O espetáculo das raças: cientistas, instituições e questão racial no Brasil (1870-1930). São Paulo: Companhia das Letras, 2011.

${ }^{85}$ Os vínculos da academia com a Igreja são evidentes, até pelo local em que foi instalada - o convento de São Francisco. Ademais, a Faculdade de Direito foi uma instituição produtora de intelectuais a serem recrutados pela burocracia estatal. Além disso, com a proximidade dos centros produtores de decisão do país, os professores não só faziam de sua atuação na escola e de sua origem social um trampolim para os postos políticos republicanos, como facilmente tinham acessoa órgãos importantes de comunicação. Ver SCHWARCZ, Lilia Moritz.O espetáculo das raça: cientistas, instituições e questão racial no Brasil (1870-1930). São Paulo: Companhia das Letras, 2011.
} 
Em seu discurso, Eduardo Prado cita Varnhagen afirmando ser ele partidário da exterminação do índio. Importante ressaltar que a questão da integração do indígena ao Estado Nacional era um debate de longa data. Muitos intelectuais formularam propostas para solucionar o problema, várias delas engendradas no $\mathrm{IHGB}^{86}$. Alguns sócios ligados à Igreja Católica defendiam, assim como Eduardo Prado, a integração via catequese religiosa, como Januário da Cunha Barbosa, Joaquim Caetano Fernandes Pinheiro, Domingos José Gonçalvez de Magalhães e Agostinho Perdigão Malheiros. Noutro extremo, entretanto, estava Francisco Adolfo de Varnhagen $^{87}$, que integrava a corrente partidária da utilização da integração pela guerra. Varnhagen era defensor da tese da superioridade das populações branca europeias sobre a população ameríndias, já que os brancos europeus traziam os pilares da formação de uma nação: a lei, a religião, a ordem e a autoridade. Portanto, caberia ao índio sua integração nesse processo de constituição da nação, caso contrário, colocava-se como inimigo interno, que deveria ser combatido com a utilização das forças armadas ${ }^{88}$. Ao contestar Varnhagen, Eduardo Prado, claramente contrapôs-se ao cerne do IHGB, já que aquele historiador norteava o perfil de intelectual que caracterizou a produção do instituto durante o período imperial.

A posição tomada por Eduardo Prado tornou-se ainda mais evidente quando afirmou que o maior serviço da Companhia havia sido a fundação da cidade de São Paulo, local em que até aquele momento estavam reunidos os descendentes das raças fundidas. Disse ainda que não era possível fazer a obra da civilização do índio em São Vicente, ou em Santos, pois o contato imediato com a gente do mar, forasteiros e aventureiros, era corruptor e fatal; e, por outra parte, a raça europeia não podia medrar, ao começo da sua imigração tropical, na costa, onde o clima the é decididamente desfavorável. Apontou, assim, a conveniência do estabelecimento de colonos europeus nos planaltos do interior, local em que habitavam "índios amigos" e onde a altitude corrigia o ardor do clima, tornando-o semelhante ao da Europa. Assim descreve São Paulo:

\footnotetext{
${ }^{86}$ Sobre o debate em torno da questão indígena desenvolvido no IHGB durante a segunda metade do século XIX, ver MOTA, Lúcio Tadeu. "O Instituto Histórico e Geográfico Brasileiro e as propostas de integração das comunidades indígenas no estado nacional". Diálogos, Maringá, v. 2, n. 2, p. 149-175, 1998.

87 Varnhagen foi considerado "pai da historiografia brasileira", já que sua interpretação da história do Brasil provou-sea mais bem sucedida durante a monarquia. Segundo Guimarães, "no plano das ideias e a partir de uma perspectiva confessadamente limitada de uma elite cultivada, ele logrou formular a base da nacionalidade brasileira. Aqui certamente está a razão importante pela qual ele - e nenhum outro - e tornou pai da historiografia brasileira" GUIMARÃES, Manoel Luiz Salgado. Historiografia e nação no Brasil 1838-1857. Rio de Janeiro: Ed. UERJ, 2011.

${ }^{88}$ MOTA, Lúcio Tadeu. "O Instituto Histórico e Geográfico Brasileiro e as propostas de integração das comunidades indígenas no estado nacional". Diálogos, Maringá, v. 2, n. 2, p. 149-175, 1998,
} 
Reduzido ao Cristianismo, isto é, à paz, um grande número de famílias de índios, aqui ficou logo formado o centro donde deviam irradiar a descoberta e a colonização do Brasil. (...) Homens mestiços, não de um tipo inferior, porque não é inferior, como têm verificado todos os americanistas, o tipo resultante do branco e do índio. Nesse cruzamento, se o branco entra com um cérebro mais desenvolvido, que se reproduz no seu descendente, o índio traz para o novo tipo a agudeza da sensibilidade dos sentidos e a agilidade elástica dos seus músculos, sentidos e músculos um tanto atrofiados no homem civilizado.

Não tivesse os jesuítas tornado os índios sedentários e mansos, e esse cruzamento, a que devemos pode dizer-se a quase totalidade da população brasileira, não se teria dado ${ }^{89}$.

Percebe-se, pois, a proeminência dada a São Paulo, centro de onde teria irradiado a civilização no Brasil. Na contramão dos pressupostos raciais, como do darwinismo social, que condenavam a mestiçagem, considerando-a causa da degeneração das espécies ${ }^{90}$, Eduardo Prado pretendeu demonstrar o contrário: que esse homem mestiço não é inferior, ideia concorde entre muitos intelectuais de São Paulo no início do século XX. Apontou, portanto, a contribuição de cada elemento no processo de fusão das raças: o cérebro mais desenvolvido do branco e os músculos e agilidade do índio.

Para ocorrer, entretanto, essa união, o papel imprescindível, tema de sua conferência, era o jesuíta. Acrescentou ainda que a obra missionária promovia a admiração entre os historiadores, pois permitiu que "seres que viviam como feras" tivessem descendentes que, naquele momento, "viviam como homens". Concluiu dizendo que foi o paulista quem, na América do Sul, alargou os domínios de Portugal, demarcando e batizando o Brasil do futuro ${ }^{91}$.

O discurso, resumido aqui, parece descrever a obra de Oscar Pereira da Silva. Interessante perceber que Eduardo Prado utiliza o termo "batismo", que é justamente a ação representada na tela. Ação esta tão marcante que, durante a exposição inaugural do quadro, o primeiro título equivocadamente ${ }^{92}$ atribuído a ele foi o Batismo

\footnotetext{
${ }^{89}$ PRADO, Eduardo. Coletâneas. São Paulo: Escola Tipográfica Salesiana, 1904, 84-85.

90 SCHWARCZ, Lilia Moritz.O espetáculo das raça: cientistas, instituições e questão racial no Brasil (1870-1930). São Paulo: Companhia das Letras, 2011, P. 58-61.

${ }^{91}$ PRADO, Eduardo. Coletâneas. São Paulo: Escola Tipográfica Salesiana, 1904, p. 87.

92 Considerei a colocação do articulista como um equívoco, pois não foi encontrada nenhuma outra evidência que demonstrasse que esse havia sido, a princípio, o título atribuído, que posteriormente fora alterado. De qualquer forma, mesmo que o artista tenha mudado o nome, isso ocorreu durante a primeira exposição da obra, já que notícias veiculadas nos dias subseqüentes, já utilizavam o nome "Fundação de São Paulo".
} 
de São Paulo, nome que aparece em uma notícia do jornal O Estado de São Paulo, em dezembro de 1907. A denominação, entretanto, não é descabida, já que é em torno do batismo que o quadro se compõe. O mais expressivo é atribuir a este ato 0 título de "fundação", o que significava dizer que a tela não era a representação de uma simples celebração religiosa que haveria ocorrido em Piratininga, mas que a gênese de São Paulo e dos paulistas foi fundamentada por meio da bênção. O alicerce da união entre índios e europeus é, portanto, a Igreja Católica.

Outra discussão, vigente desde o final do século XIX, que mantinha relações inequívocas com o quadro foram os debates em torno dos progenitores dos paulistas. O orgulho da ascendência colonial das elites cafeicultoras era promovido por trabalhos publicados durante as primeiras décadas republicanas, como a célebre Genealogia paulistana, obra monumental em nove volumes de Luiz Gonzaga da Silva Leme, que reconstituía as ligações entre as famílias fazendeiras e os povoadores quinhentistas e seiscentistas. Além das obras escritas individualmente, instituições como IHGSP e Museu Paulista também empenharam-se na tarefa de traçar uma identidade característica a São Paulo e procuravam transformar os paulistas sertanejos nos míticos bandeirantes, por meio do enaltecimento do papel dos patriarcas das famílias mais proeminentes dos tempos das bandeiras e também da cafeicultura.

Nesse contexto, um assunto que ganhou grande destaque dentre os artigos da revista do IHGSP, entre anos de 1902 e 1904, foi a figura de João Ramalho, tido por memorialistas do século XVIII, como Pedro Taques ${ }^{93}$ e Frei Gaspar da Madre de Deus $^{94}$, como "patriarca dos paulistas". Esses estudiosos haviam defendido a origem fidalga do "alcaide-mor da borda do Campo", que teria tido "foro de cavaleiro" (ABUD, 1985: 95). O debate em torno dessa figura, entretanto, foi suscitada em uma das sessões do IHGSP, quando o consócio João Mendes Júnior sugeriu que João Ramalho era analfabeto e possivelmente não era cristão, características que poderiam, sob olhos preconceituosos, máculas à tradição paulista. Tal colocação lançou o IHGSP à tarefa de conferir um contorno mais preciso à figura de João Ramalho. Para tanto, montou-se uma comissão composta por Teodoro Sampaio, Orville Derby, Antônio de Toledo Piza, João Mendes de Almeida Júnior e Manoel

\footnotetext{
${ }^{93}$ Pedro Taques de Almeida Paes Leme foi autor de Nobiliarquia Paulistana; sobre sua obra ver: ABUD, Kátia. O sangue intimorato e as nobilíssimas tradições - a construção de um símbolo paulista: 0 bandeirante. São Paulo: USP. 242 p. Tese (doutorado) -Faculdade de Filosofia, Letras e Ciências Humanas, Universidade de São Paulo, São Paulo, 1985, p. 62-108.

${ }^{94}$ Frei Gaspar da Madre de Deus foi autor de Memórias para a História da Capitania de São Vicente, hoje chamada de São Paulo, do Estado de Brasil. Sobre a sua obra Ver ABUD, Kátia. O sangue intimorato e as nobilíssimas tradições - a construção de um símbolo paulista: o bandeirante. São Paulo: USP. 242 p. Tese (doutorado) -, Faculdade de Filosofia, Letras e Ciências Humanas, Universidade de São Paulo, São Paulo,1985, p. 62-108.
} 
Pereira Guimarães, a fim de verificar nos originais das atas de vereança da vila de Santo André da Borda do Campo e de São Paulo de Piratininga se a hipótese procedia.

O parecer final, divulgado no sétimo volume da Revista do IHGSP, iniciou-se com a seguinte descrição de João Ramalho: "figura legendária do primeiro europeu que outrora habitou estes campos em que hoje floresce S. Paulo", portanto, sem demonstrar qualquer vínculo com a progênie paulista. Os membros da comissão basearam-se em depoimentos do jesuíta Simão de Vasconcelos, que apontavam João Ramalho como violento, tendo cometido graves crimes, infame e até ter sido excomungado. O resultado das pesquisas pretendeu provar que o mesmo era analfabeto, pois não sabia escrever o próprio nome, usando um sinal para a sua assinatura. Sinal esse, muito próximo à letra hebraica $\ni(k a f)$, que levou os membros da comissão a crer que ele não era cristão, sendo, possivelmente, judeu.

O resultado do parecer, entretanto, não foi um consenso. Houve até uma cisão na comissão julgadora, já que Manoel Pereira Guimarães discordava dos demais integrantes. Ele escreveu, então, uma réplica ao artigo, divulgada não só na Revista, mas também n'O Estado de São Paulo ${ }^{95}$. Nela, questionava a análise da comissão feita nos documentos e procurava reafirmar que João Ramalho não era criminoso, nem inimigo dos jesuítas. Pelo contrário, teria sido por iniciativa dele que havia se erigido uma povoação nos campos do planalto de Piratininga.

O questionamento de Guimarães deu ensejo ao intenso debate que dividiu os membros do IHGSP. Segundo Ferreti e Capelato, havia duas principais alas que dividiam os sócios da instituição: a dos jesuítas, sob a égide de Eduardo Prado, e aqueles que pretendiam reabilitar João Ramalho, como Francisco de Campos Andrade e J. C. Gomes Ribeiro ${ }^{96}$. Esses teriam prevalecido, ao conseguirem reabilitar a figura do alcaide-mor da Borda do campo, atribuindo-lhe papel de destaque dentre os patriarcas paulista, tal como procurou demonstrar Gomes Ribeiro:

Pensamos ter demonstrado, na medida de nossas forças, a iniquidade do lábio atirador, através dos séculos, ao benemérito fundador de $S$. André, ao lendário progenitor dos sertanistas bandeirantes de S. Paulo, ao velho servidor público, ao fidalgo de títulos do próprio esforço, cuja memória bem merecia uma reabilitação pública, arvorando-se, ao menos, no local da sua querida vila, tão próximas dessa capital, um padrão que atentasse

\footnotetext{
${ }^{95}$ O Estado de São Paulo, 20 de julho de 1902.

${ }^{96}$ FERRETTI, Danilo José Zioni; CAPELATO, Maria Helena Rolim. João Ramalho e as Origens da Nação: os paulistas na comemoração do IV centenário da descoberta do Brasil. Tempo, Niterói, v. 04, n.08, p. 67 87, 1999.
} 
aos pósteros a gratidão dos Paulistas, seus descendentes e continuadores, na energia, na iniciativa e no civismo ${ }^{97}$.

Na obra de Oscar Pereira da Silva é possível perceber claramente a que ala o artista se filiou, já que é evidente a primazia atribuída aos jesuítas, como já foi demonstrado. Vale destacar, entretanto, que o artista não estava alheio a estas discussões, por isso, inseriu João Ramalho em sua representação, sendo conivente, portanto, com a corrente que defendia o seu papel como patriarca paulista, ainda que coadjuvante na cena pintada.

Ainda no âmbito dos progenitores paulistas, um debate bem mais acalorado foi aquele em torno da filiação linguística e cultural dos habitantes nativos do planalto de Piratininga $^{98}$. Segundo John Monteiro, a questão foi suscitada por João Mendes de Almeida que, em 1888, durante uma sessão solene da Sociedade dos Homens de Letras de São Paulo, leu uma memória sobre o ataque indígena à vila paulistana em $1562^{99}$. Com base num manuscrito atribuído ao padre José de Anchieta, ele constatou que os "dominadores" de Piratininga não eram os Guaianá, o que abalou o mito de origem da sociedade paulista, pautada nas afirmações sobre os Guaianá de Piratininga e as origens tupi da grandeza de São Paulo ${ }^{100}$.

Essa polêmica estendeu-se por muitas páginas da revista do IHGSP e do Museu Paulista ${ }^{101}$. Aqui, entretanto, ela será apenas citada, pois interessa demonstrar como o índio se constituiu como elemento de importância a historiadores paulistas, que buscavam incorporá-lo à nação brasileira, não apenas nas memórias histórica como também nas políticas do Estado. Tal intenção inseria-se novamente nas dimensões renovadas do contato inter-étnico, visto que o resgate das origens tupi da cidade e do povo de São Paulo estavam envoltas por uma outra questão do período: o extermínio dos índios Kaingang, ocasionado pela expansão da fronteira cafeicultora

\footnotetext{
97 Revista do Instituto Histórico e Geográfico de São Paulo, 1902.

98 Sobre o debate da filiação linguística e cultural dos habitantes nativos do planalto de Piratininga, ver MONTEIRO, John M. Tupis, Tapuias e a História de São Paulo. Revisitando a velha questão guaianá. Novos Estudos. CEBRAP, São Paulo, v. 34, p. 125-135, 1992.

99 Esta memória foi republicada no volume VII da Revista do Instituto Histórico e Geográfico de São Paulo, em 1902, com o título "Qual foi o principal chefe da nação Tupi, na região nomeada Piratininga? Quem comandou o cerco e ataque de Piratininga em 10 de julho de 1562?".

${ }^{100}$ MONTEIRO, John M. Tupis, Tapuias e a História de São Paulo. Revisitando a velha questão guaianá. Novos Estudos. CEBRAP, São Paulo, v. 34, 1992, p.125-126.

101 O debate se estendeu até, pelo menos 1912, portanto, quando a Fundação de São Paulo já estava pronta.
} 
para o oeste paulista ${ }^{102}$. Portanto, os artigos publicados ora tratavam dos índios do início da colonização, ora referiam-se aos índios contemporâneos, questões, claramente inter-relacionadas.

Capistrano de Abreu, personagem proeminente no IHGB, defendeu, em um de seus ensaios denominado Caminhos antigos e povoamento do Brasil, que os Guaianá da documentação antiga não configuravam grupos Tupi; ao contrário, eram os remotos ancestrais dos modernos Kaingang, portanto tapuias, uma "raça" indígena desprezada pela ciência moderna e pelos defensores do progresso. Essa colocação contrapunhase à imagem firmemente estabelecida do robusto e valente guaianá, precursor tupi do povo paulista.

A polêmica invadiu as páginas da revista do IHGSP, com artigos de Theodoro Sampaio, em 1897 e 1903, que procuraram reafirmar que os Guaianá eram, de fato, um grupo não-tupi mas não eram os principais habitantes das áreas posteriormente colonizados pelos portugueses, demonstrando, assim, a incorreção da tradição:

Somos ainda levados a concluir que o gentio dominador nos campos de Piratininga não era da nação Guayaná; que Tibiriçá, Caiuby e os da sua tribo não eram dessa nação (...) que o gentio dominador tanto no litoral da capitania como no seu sertão era da raça tupi, de cuja língua procede quase todo o vocabulário geográfico paulista (...) e, finalmente,que a raça mestiça, a dos mamelucos, donde saíram os bandeirantes, conquistadores de sertão, não era do sangue guayaná, mas dos tupiniquins, ou verdadeiramente do tupi, da mesma raça de que descende grande parte da nação brasileira. Quer isso significar não somente uma correção em velhas e arraigadas tradições, erroneamente divulgadas sem crítica, como principalmente uma reparação, uma restituição, tardia embora, a essa raça tupi, graças à qual, pela sua fácil assimilação, pode o português, pequeno no número, mas grande no heroísmo, lançar na América Tropical, em quase metade do continente do sul, os fundamentos de uma nacionalidade nova ${ }^{103}$.

Concorde a esse posicionamento, nos artigo escritos da Revista do Museu Paulista publicada em 1904, Herman von Ihering, diretor dessa instituição, tentou atribuir um caráter científico à discussão. Dessa maneira, recorreu não só o exame lingüístico, mas também o etnográfico - sobre a diferença na fabricação de tecidos - e

\footnotetext{
102 A polêmica a respeito do extermínio indígena vigente no século $X X$ será mais profundamente abordada no capítulo 2, já que o cerne da questão foi no ano de 1908, portanto, quando a tela de Oscar Pereira da Silva já estava pronta. Neste primeiro capítulo tentou-se traçar o universo de possibilidade que os historiadores propunham para a origem de São Paulo e, sobretudo, perceber quais foram as escolhas do artista para compor a obra, portanto, o discurso que ele pretendia dar visualidade por meio da tela.

${ }^{103}$ Revista do Instituto Histórico e Geográfico de São Paulo, 1896-1897.
} 
antropológico - formato do crânio - que confirmaram a hipótese de que os Guaianá de Piratininga não pertenciam à raça tupi-guarani.

Diante desses posicionamentos, os defensores da "velha tradição" como Afonso Freitas e Gomes Ribeiro manifestaram-se, respondendo às acusações que lançavam por terra o mito paulista baseado na mestiçagem com os tupis. Além do debate em torno da filiação linguística e cultural dos índios de Piratininga, havia ainda a dúvida de quem seria o seu chefe - Tibiriçá, Caiuby ou Piquerobi - e qual o papel dele na fundação de São Paulo ${ }^{104}$.

A fim de analisar as escolhas feitas por Oscar Pereira da Silva para a composição de sua tela, interessa mais perceber a inquestionável importância do indígena nos debates historiográficos paulistas, do que entender que lado prevaleceu no debate historiográfico, já que a discussão ainda estava em andamento quando o quadro ficou pronto. $O$ índio constituía-se indubitavelmente um dos elementos que havia contribuído para a formação da "raça de paulista". É relevante, assim, perceber as qualidades transmitidas aos seus descentes, que foram reveladas na obra, que se apoiou nos historiadores.

É possível notar o posicionamento de Oscar Pereira da Silva por meio dos atributos físicos dado aos seus índios, já que, no caso dos homens, seus corpos são musculosos e demonstram virilidade - característica que, como já foi indicado ${ }^{105}$, era tributária dos nativos. Ademais, há uma grande quantidade de armas nas mãos dos índios, porém, nenhuma delas empunhadas contra o europeu, o que indica serem mansos e amigos - ideia reiterada pela quase inexistência de armas nas mãos dos europeus. Essa descrição condiz com a tradução, apresentada por Theodoro Sampaio $^{106}$, do vocábulo "Guaianá", pois "guaya”, significaria manso, pacífico, bom; e "guayanã", verdadeiramente manso, bonachão, tradução esta que se conforma com a índole e viver da nação gentia que outrora havia habitado São Paulo, como propunham os membros do IHGSP defensores da tradição, que proclamava que os índios que deram origem aos paulistas eram guaianá e tupi.

\footnotetext{
104 João Mendes de Almeida afirma que era Piquerobi o chefe da nação indígena em Piratininga, enquanto Gomes Ribeiro e Afonso Freitas dizem ter sido Tibiriçá. Este último afirma ainda que foi graças a Tibiriçá que os jesuítas teriam "subido a serra". ALMEIDA, João Mendes de. Qual foi o principal chefe da nação Tupi, na região nomeada Piratininga? Quem comandou o cerco e ataque de Piratininga em 10 de julho de 1562?. Revista do Instituto Histórico e Geográfico de São Paulo, São Paulo, v. VII, 1902.

${ }^{105}$ Refiro-me ao discurso de Eduardo Prado, analisado anteriormente.

${ }^{106}$ SAMPAIO, Teodoro e DERBY, Orville. Qual a verdadeira grafia do nome Guayaná? Goyaná ou Guayaná?,Revista do Instituto Histórico e Geográfico de São Paulo, São Paulo, v.II, 1896/97, p. $27-34$.
} 
Outro elemento pelo qual se pode caracterizar o índios é a choupana feita de madeira e folhagens, na qual é possível ver uma rede. Esses elementos são citados em artigos ${ }^{107}$ de von lhering que, ao caracterizar índios tupi-guaranis ${ }^{108}$, disse:

As suas cabanas denominas de "tapui" são espaçosas, construídas de madeira e coberta de folha de palmeira. Estas cabanas são construídas no mato, onde preparam também as roças destinadas às suas plantações. Como alimento, em primeiro lugar thes serve o milho; plantam também mandioca, batatas e algodão, e deste sabem confeccionar tecidos, elegantes forros, etc. Os homens são bons caçadores e pescadores e sabem pegar muitos animais e mundéus e urupucas $^{109}$.

A descrição assemelha-se à construção presente no quadro de Oscar Pereira da Silva. Ainda que o nascimento da cidade não tivesse na arquitetura uma figuração protagonista, ela está representada, como sinal evidente de intenção de mínima de traço permanente. Eram os traços urbanos que nasciam, ainda que advindos de povo não urbanizado. Mais um encontro mestiço, no qual a aurora da cidade era favorecida pela construção de um índio tendente ao contato e, portanto, à civilização.

Vale destacar ainda que essa nação indígena tinha o hábito de dormir em redes (como a que aparece na tela de Oscar Pereira da Silva), o que era desconhecido entre os Kaingangs, por isso, ao descrever esta nação, Ihering diz que eles dormem no chão ${ }^{110}$, além disso esses índios não usariam roupas durante o verão e não usariam muitos adornos, muito diferente, portanto, do índios da tela. São detalhes sutis, porém, que têm grande significado no âmbito dos debates de então.

107 Segundo Stauffer, esse artigo foi fruto de uma monografia, apresentada na Exposição de St. Louis
(EUA), em 1904 e publicada em inglês no jornal O Estado de São Paulo, em 1906. Foi depois traduzida e
publicada no volume de 1907 da Revista do Museu Paulista, que circulou em meados de 1908. Ver
STAUFFER, David Hall. "Origem e Fundação do Serviço de Proteção aos Índios (1889-1910)" trad. de J.
Philipson. Revista de História, USP, São Paulo, no. 42, 1960.

${ }^{108}$ Ihering descreve o que chama de "índios atuais". Afirma que existem dois grupos: os Guaranis e os "Gês", que seriam o elemento predominante tapuia. Descreve o primeiro grupo como "Guaranis ou Tupis meridionais" e afirma que seriam esses os cristianizados. Desse grupo, ele descreve o Cayuás, conforme a citação que se segue. Ihering, Hermann von. Antropologia do estado de São Paulo. Revista do Museu Paulista, São Paulo,v. VII, 1907.

${ }^{109}$ Revista do Museu Paulista, vol. 7, 1907.

110 "As míseras choupanas dos Kaingangs consistem apenas em algumas varas enfincadas no chão, no interior da mata; formam uma espécie de toldo de barraca aberto nos dois lados, com cumieira no meio e coberto com folha de palmeiras. São pequenas e evidentemente destinadas a um só casal, os índios dormem no chão sobre uma cama de folhas seca."Revista do Museu Paulista, v. VII, 1907, p. 212. A descrição assemelha-se com a que Oscar Pereira da Silva retratou na sua tela, o que poderia gerar dúvida se ele teria retratado tupis ou tapuias. Porém, é possível notar que na descrição da choupana tapuia ele afirme que eram "varas enfincadas no chão", enquanto na descrição tupi ele diz ser "madeira". Além disso, ele afirma que os tapuias dormem no chão, enquanto, os tupis ele afirma dormirem em redes. $\mathrm{Na}$ choupana da tela é possível notar uma rede, portanto, não poderiam ser tapuias. 
Percebe-se, portanto, que Oscar Pereira da Silva construiu uma imagem condizente com as pesquisas historiográficas, porém, permeada por escolhas. $O$ modelo que ele compôs apresenta uma imagem do índio como submisso, que aceitou naturalmente a religião e uniu-se amigavelmente ao europeu. Este não foi o único modelo proposto para representar as fundações de espaços urbanos, na passagem do século XIX para o $X^{111}$.

Uma imagem deveras distinta da de Pereira da Silva foi a Fundação de São Vicente, realizada em 1900 por Benedito Calixto ${ }^{112}$, doada ao Museu Paulista pela comissão organizadora das comemorações do IV Centenário da Descoberta do Brasil em Santos. Nela, o espaço é caracterizado pela extensibilidade e indiferenciação, já que não há nenhum tipo de compartimentação ou especialização que sugira uma hierarquia. Há uma grande quantidade de figuras que se espraiam até o perímetro da tela e não estão separadas em áreas de concentração. Há, portanto, uma mescla de indígenas e europeus, em tranqüilidade, e desenvolvendo uma variada gama de comportamentos. A ação que funda a cidade é um evento político - o encontro de índios e portugueses. O modelo de representação proposto por Benedito Calixto seria, portanto, o da aceitação.

Uma terceira possibilidade foi formulada por Antônio Parreiras na obra Fundação de São Paulo, de 1913, encomendada pela prefeitura da cidade (figura 15). Apesar de se utilizar da temática religiosa, assim como Pereira da Silva, a organização da obra e o destaque dado a cada elemento é bem distinto. Utiliza-se também dos três tipos: os índios, os brancos colonizadores e os jesuítas, sem, no entanto, ter a centralização e hierarquia na fé e no clero que havia na outra imagem. Há um destaque para a figura de Manuel de Paiva, padre que reza a missa, pois ele está no altar, um pouco acima das demais figuras e destacado pela luz. Contudo, não há uma diferenciação entre o europeu e o índio, já que estão lado a lado, em primeiro plano, embora o colonizador esteja ajoelhado. O índio está também em pose elevada e

\footnotetext{
${ }_{111}$ Agradeço a John Monteiro que, duranteo meu exame de qualificação, propôs que eu analisasse as telas de Pereira da Silva, Benedito Calixto e Parreiras, seguindo este viés de comparação com base em três modelos: submissão, aceitação e insubmissão, respectivamente.

${ }^{112}$ Para análise mais detalhada da tela de Benedito Calixto em comparação com a de Pereira da Silva ver MONTEIRO, Michelli Cristine Scapol . Fundação de São Paulo, de Oscar Pereira da Silva: a construção de uma representação urbana na pintura histórica. XXVI Simpósio Nacional de História- Anais, São Paulo, 2011. Outras obras que tratam das telas desse artista, e inspiradores para a análise que apresentada, são: MENESES, Ulpiano T. Bezerra de . Benedito Calixto como documento: sugestões para uma releitura histórica. In: D. Sala. (Org.). Benedito Calixto: memória paulista. São Paulo: Pinacoteca do Estado, 1990, p. 37-47 e ALVES, Caleb Faria. Benedito Calixto e a construção do imaginário republicano. Bauru: EDUSC, 2003.
} 
imponente, sobretudo pelos braços cruzados - muito diferente dos índios de Pereira da Silva, mansos e resignados. O método proposto por Parreiras é, portanto, o da insubmissão.

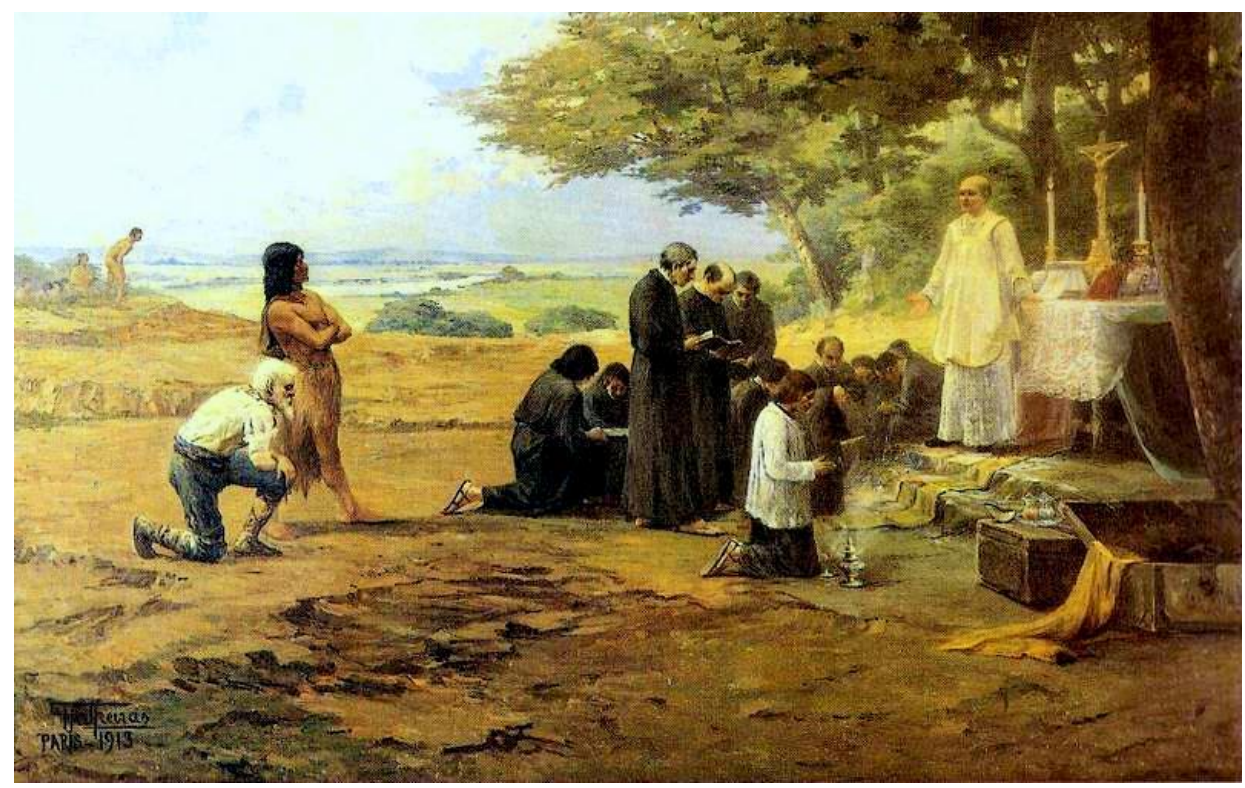

Figura 15 - Antonio Parreiras, Fundação de São Paulo, 1913. Óleo sobre tela, $200 \times 300$ $\mathrm{cm}$. Prefeitura de São Paulo. Retirado de http://laboratorioart.blogspot.com.br/2012/03/visita-ao-pateo-do-collegio-sao-paulo.html Acesso em 20/11/2012

Importante destacar que, tanto a obra de Benedito Calixto quanto a de Antônio Parreiras, foram encomendadas, portanto havia um maior controle sobre a representação. A tela de Oscar Pereira da Silva, como já foi dito, foi feita com recursos próprios, com a pretensão de vendê-la ao Estado e impulsionar a sua carreira artística, algo capaz de consagrá-lo como pintor da história paulista por excelência. Dessa maneira, as escolhas do artista na elaboração de sua obra deveriam contemplar convenções pictóricas, a historiografia paulista e a ideologia dos políticos.

O resultado disso foi a Fundação de São Paulo, que localizou a miscigenação como fundamento de uma identidade racial paulista, reservando ao português uma posição de superioridade e ao indígena as qualidades guerreiras naturais. $O$ contato entre índios e europeus é desprovido de qualquer conflito ou violência, sobretudo, pela ênfase atribuída à catequese jesuítica e ao ato da bênção. A cidade que ali tinha sua aurora como missão jesuítica era, pois, uma predestinação de convívio urbano, mediante a submissão dos "diferentes" ao ato simbólico fundador. A metrópole do início do século $X X$, lotada de contrastes oriundos da imigração, tinha, portanto, seu 
vaticínio pelos pincéis de Oscar Pereira da Silva. Um vaticínio que era, aliás, emblema para o próprio estado e para suas fronteiras agrícolas que presentificavam os contatos inter-étnicos dos Quinhentos.

Agora que as escolhas haviam sido feitas e o quadro estava pronto, restava divulgá-lo ao grande público e, principalmente, aos políticos, que eram os potenciais compradores. É com esse objetivo que o artista decidiu convidar o presidente do estado para a sua exposição, como foi noticiado n'O Estado de São Paulo, em 12 de dezembro de 1907:

Esteve ontem em palácio, onde foi convidar o Sr. Presidente do Estado para visitar a exposição de pintura que brevemente inaugurará no salão nobre do "Progredior", o pintor Oscar Pereira da Silva ${ }^{113}$.

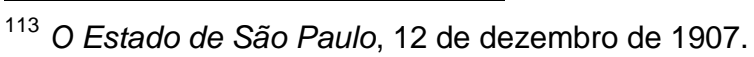




\section{Capítulo 2}

\section{Entre História e Arte: recepções em conflito}

Hoje, às 11 horas da manhã no Salão Progredior, realiza-se a inauguração da grande tela do pintor Oscar Pereira da Silva, o "Batismo de São Paulo".

Recebemos um convite para esse ato ${ }^{1}$.

Como foi demonstrado no primeiro capítulo, as ambições que envolveram a Fundação de São Pauloeram enormes, já que o esforço empreendido por Oscar Pereira da Silva na realização da obra deveria Ihe garantir um status definitivo depintor privilegiado da história paulista, capaz de lhe proporcionar novas encomendas públicas de telas e a inserção plena no meio artístico de São Paulo. Para tanto, a exposição da tela deveria ser um grande evento, muito divulgado e bem frequentado.

O sucesso da mostra dependia de diversos fatores, dentre eles um local adequado para a exibição da obra. Mas a cidade de São Paulo, no início do século XX, não possuía espaços especializados para exposições artísticas. Na ausência de galerias de arte, havia alguns lugares alternativos, como hotéis, teatros, casas fotográficas, instituições de ensino, cafés, confeitarias e casas de comércio, que se transformaram em importantes agentes no cenário artístico da capital. Esses espaços concentravam-se, sobretudo, no triângulo formado pelas ruas Direita, Quinze de Novembro e São Bento.

A rua Quinze de Novembro era o centro comercial por excelência da cidade, pois ali se concentravamlojas sofisticadas como a joalheria Bento Loeb a Casa Michel, a chapelaria Henrique Martins, a tabacaria Caruso, a Livraria Garraux, a oficina de costura Casa Bonilha, a Casa Levy de pianos, o salão de belezas La Grande Duchessel e a loja de roupas $A$ Pygmalion. Além do comércio elegante, nesta rua era possível encontrar importantes estabelecimentos bancários, como London e Brazilian Bank, Banco união de São Paulo, Banco Commercio e Indústria, London and River Plate Bank e Banco Alemão. Era lá que estavam também as sedes dos jornais e revistas de maiores destaques, como O Estado de São Paulo, Correio Paulistano, Diário Popular, o Platéa. Ali ficavam também o Club Internacional, a sede da São Paulo Railway, e o Jockey Club.

\footnotetext{
${ }^{1}$ Esta notícia foi publicada na coluna Artes e Artistas do jornal O Estado de São Paulo, em 14 de dezembro de 1907, porém, não foi assinada.
} 
No número 38 desta rua, entre Companhia Mecânica e a Casa Garraux, e seguido pelo Banco Alemão, encontrava-se o Progredior. Segundo Heloisa Barbuy, este era o mais luxuoso restaurante da capital no final do século XIX e, por certo, o mais cosmopolita daqueles anos ${ }^{2}$. Já em sua inauguração, em 20 de dezembro de 1892, o Progredior foi objeto de um longo artigo do jornal O Estado de São Paulo, que o considerou o "mais belo café-restaurante da América do Sul"3 e descreveu cada um de seus ambientes. Disseestar situado no pavimento térreo de um grande edifício que fora reformado pela Companhia Progredior. Afirmou que o local contava com um grande salão, em que ficava a cafeteria e o bar americano, uma área coberta de vidraçaria em que se realizavam o lunch, além de um restaurante, uma grande área descoberta e um pequeno terraço, de onde era possível ver a cidade: a várzea do Carmo, o bairro do Brás e, ao longe, a serra da Cantareira. A decoração intercalava elementos ligados ao café, atividade econômica por excelência de São Paulo, e outros alegóricos, como o vasto painel representando a apoteose do Progresso. Segundo o jornal, era "um estabelecimento modelo, luxuosíssimo, muito rico e de muito bom gosto"4.

Segundo Barbuy, o local era apontado como ícone do cosmopolitismo, em primeiro lugar, por sua localização, na rua principal, e pela arquitetura imponente e sintonizada com o ecletismo europeu. Em seguida, por toda sua decoração e aparato internos: pinturas suaves nas paredes, espelhos, ornamentos dourados, porcelanas e cristais. Num dos salões havia uma buvette com uma fonte de onde jorravam várias espécies de bebidas. $E$ até a indumentária dos garçons, que vestiam jaquetas pretas e longo avental branco, pretendia se remeter à moda europeia. Tudo, em resumo, prometia transportar o frequentador aos melhores salões da Europa, ideia que era revigorada pela predisposição de uma elite local já instruída pelas referências internacionais e que almejavam uma São Paulo internacionalizada tanto na economia como na "arte de bem viver" 5 .

Foi possível constatar, pelas diversas divulgações nos jornais, que o Progredior era um ambiente privilegiado de encontro e lazer da elite paulistana, já que seu vasto

\footnotetext{
${ }^{2}$ BARBUY, Heloisa. A cidade-exposição: comércio e cosmopolitismo em São Paulo, 1860-1914.São Paulo: Edusp, 2006.

${ }^{3}$ Segundo a notícia do jornal O Estado de São Paulo, de 20 de dezembro de 1892, página 1.

${ }^{4}$ A descrição e citação foram retiradas de O Estado de São Paulo de 20 de dezembro de 1892, p.1.

${ }^{5}$ BARBUY, Heloisa. A cidade-exposição: comércio e cosmopolitismo em São Paulo, 1860-1914.São Paulo: Edusp, 2006, p. 124-125
} 
salão era utilizado para a realização de leilões ${ }^{6}$, concertos $^{7}$, campeonatos de xadrez ${ }^{8}$, além de lá ocorrer projeção de filmes ${ }^{9}$. Seu pavimento superior era, ainda, locado pelo Jockey Club $^{10}$. A partir do dia 14 de dezembro de 1907, o Progredior acolheu a exposição de quadros de Oscar Pereira da Silva. Ele certamente esperava beneficiarse do público privilegiado que freqüentava o local para expor, pela primeira vez, a sua grande tela Fundação de São Paulo. A localização do Progredior era, aliás,bastante propícia para a exposição, já que ele, além de estar no seio comercial da Paulicéia, localizava-se muito próximo ao local em que o evento retratado na tela teria ocorrido. Era imprescindível, portanto, que a obra representativada origem da cidade estivesse exposta em um ambiente capaz de aguçar o olhar do espectador, com a evidente intenção de remetê-lo ao momento histórico que ali se apresentava.

Além da escolha do ambiente ideal, a presença do público era outro elemento de suma relevância para o sucesso de sua exposição. A fim de assegurar a presença das pessoas proeminentes, o artista tomou algumas providênciasestratégicas, comoir pessoalmente ao palácio do governo, três dias antes da inauguração,convidar ninguém menos do que o Presidente do Estado, Jorge Tibiriçá, para a sua mostra ${ }^{11}$.

Oscar Pereira da Silvatambém enviou um convite para o jornal $O$ Estado de São Paulo, que além de contar com importantes personagens da elite paulista no seu quadro de funcionários, colaboradores e assinantes, garantiu a divulgação da sua exposição. A tela ganhou espaço privilegiado na coluna de arte desse jornal, que dedicou ao menos cinco artigos $^{12}$ detalhando o evento.

\footnotetext{
${ }^{6}$ Os leilões eram muito noticiados, como é possível verificar em O Estado de São Paulo de 17 de março de 1983, página 2; e O Estado de São Paulo 10/03/1893, p. 3.

${ }^{7}$ Eram muitas as notas que divulgam concertos no Progredior, como a de 01 de novembro de 1897, a de 05 de outubro de 1899 e a de 22 de outubro de 1899, todas publicadas no jornal O Estado de São Paulo.

${ }^{8}$ O Progredior era o local os torneios realizados organizados pelo Clube de Xadrez, como se observa na notícia de 13 de novembro de 1904 e 16 de dezembro do mesmo ano, como foi noticiado pelo jornal $O$ Estado de São Paulo.

${ }^{9}$ Segundo a notícia do jornal O Estado de São Paulo de 02 de dezembro de 1907, as projeções eram animadas e sem trepidações, pois tinham o "aparelho mais nítido e mais perfeito da atualidade". Em 1908, como consta na notícia de 17 de outubro de 1908 de O Estado de São Paulo, o estabelecimento comprou um cinematógrafo "um novo aparelho da casa Pathé, muito aperfeiçoado e ainda não conhecido na América do Sul".

${ }^{10}$ É dito no jornal O Estado de São Paulo, em 20 de dezembro de 1892, que "os altos do prédio são arrendados ao Jockey-Club".

11 "Esteve ontem em palácio, onde foi convidar o Sr. Presidente do Estado para visitar a exposição de pintura que brevemente inaugurará no salão nobre do "Progredior" o pintor Oscar Pereira da Silva". 0 Estado de São Paulo, 12 de dezembro de 1907.

${ }^{12}$ Os artigos veiculados por O Estado de São Paulo sobre a primeira exposição da tela Fundação de São Paulo foram publicados nos dias 12, 14, 15 e 31 de dezembro de 1907 e 01 de janeiro de 1908.
} 
É importante destacar o papel exercido pela imprensa paulistana nesse período, uma vez que os jornaiseram instrumentos de manipulação de interesses e de intervenção na vida social. Não eram meros "veículos de informação", transmissores imparciais e neutros dos acontecimentos, mas órgãosmodeladores de opinião pública e agentes evidentes na vida política ${ }^{13}$. O periodismoresultava em segmento empresarial polivalente, de influência na otimização dos demais, isto é, da lavoura, do comércio, da indústria e também da arte, posto que as informações, a propaganda e a publicidade nele estampadas influenciavam aqueles circuitos, dependentes do meio impresso em suas variadas formas. O jornal, a revista e o cartaz - veículos da palavra impressa - potencializavam o consumo de toda ordem ${ }^{14}$.

Os periódicos constituíam-se, portanto, ferramentas de suma importância para a divulgação do trabalho artístico e para a formação de uma opinião favorável a uma determinada obra. Ademais, a imprensa era de grande relevância para a promoção comercial, inclusive quando se tratava da venda de quadros, mormente os de grande formato, como o de Oscar Pereira da Silva. Obter o apoio da imprensa e do público era um meio de facilitar a aquisição pública da obra. A grande quantidade de notas divulgadas sobre o artista e suas exposições nos leva a crer que ele mantinha um bom relacionamento com os grandes periódicos, como O Estado de São Paulo ${ }^{15}$ e o Correio Paulistano ${ }^{16}$, que contribuiu para promover sua mostra e divulgar sua obra.

O jornal Correio Paulistano surgiu no ano de 1854, sob a direção de Joaquim Roberto de Azevedo Marques. Segundo Lilia Schwarcz ${ }^{17}$, o veículo esteve ligado a vários grupos políticos, pois alterou diversas vezes de posição, seguindo o interesse de seus proprietários.Sua vinculação só teria ficado mais estável quando, a partir de 1882, o periódico foi adquirido por Antônio da Silva Prado, chefe da União

\footnotetext{
${ }^{13}$ CAPELATO, Maria Helena Rolim; PRADO, Maria Ligia Coelho. O Bravo Matutino. Imprensa e Ideologia: O Jornal O Estado de S.Paulo. São Paulo: Alfa-Omega, 1980.
}

\footnotetext{
${ }^{14}$ MARTINS, Ana Luiza. Revistas em revista:Imprensa e práticas culturais em tempos de República. São Paulo: Edusp, Fapesp, Imesp, 2001, p. 166.

${ }^{15}$ O jornal O Estado de São Paulo divulgou muitas exposições de Oscar Pereira da Silva, como é possível verificar nas edições de 01 de março de 1898, 3 de setembro de 1901, 12 de fevereiro de 1905 e 18 de janeiro de 1906, para citar alguns exemplos. O apoio ficou ainda mais evidente durante a exposição de 1907 e durante toda a campanha a favor da aquisição da obra, como está exposto ao longo deste capítulo.

${ }^{16}$ O Correio Paulistano também foi um grande divulgador de Oscar Pereira da Silva, como é possível verificar nos exemplares de 03 de maio de1900, 29 de maio de 1902 e 03 de fevereiro de1906, para citar alguns exemplos. Não foram encontradas notícias da exposição do quadro Fundação de São Paulo, em 1907. Em contrapartida, a exposição de 1909 foi noticiada pelo Correio Paulistano com uma extensa matéria dedicada ao quadro em 04 de agosto de 1909.

${ }^{17}$ Schwarcz, Lilia Moritz. Retrato em branco e negro: jornais, escravos e cidadãos em São Paulo no final do século XIX. São Paulo: Companhia das Letras, 1987.
} 
conservadora, passando, assim, a fazer oposição aos liberais. Antonio Prado era uma figura de destaque, tanto por suas atividades na área econômica - ligado à cafeicultura, à ferrovia e à política de imigração -quanto por sua atuação política. Os acontecimentos de 15 de novembro de 1889 transformam novamente o posicionamento do Correio Paulistano, que passou a defender a República, tornandose, inclusive, órgão oficial do Partido Republicano, enquanto Antonio Prado foi aclamado líder deste partido. Em junho de 1890, o jornal foi adquirido por um grupo de republicanos, entre os quais o Manuel Gonçalves Camillo e o capitão Manuel Lopes de Oliveira, tornando-se depois propriedade de uma sociedade anônima da Fundação da República. Nelson Werneck Sodré ${ }^{18}$ demonstra como a tiragem do jornal aumentou significativamente, já que em 1882 eram publicados 850 exemplares, enquanto em 1904 esse número chegou a 8500. Para Lilia Schwarcz, diferentemente de outros jornais da época, que buscavam se mostrar apegados aos novos valores e ideias, o Correio Paulistano marcou sua especificidade majoritariamente a partir de seu estilo e conteúdo absolutamente conservador ${ }^{19}$.

A primeira edição de $O$ Estado de São Paulofoi a de 4 de janeiro de 1875, com o nome de Província de São Paulo. Segundo Cleber Sebastião Fabbri ${ }^{20}$ e Lilia Schwarcz, a ideia de criação do jornal surgiu durante a Convenção de Itu, quando republicanos paulistas de várias regiões reuniram-se para formar definitivamente um partido, dessa maneira, o veículo seria um meio de comunicação e divulgação dos ideais defendidos na convenção.O jornal, entretanto, só assumiu uma postura francamente republicana em 1884, mesmo ano em que passou a ser propriedade de Alberto Sales \& Cia. No ano seguinte, Alberto Sales afastou-se da direção do jornal, que foi assumida por Julio de Mesquita quando a tiragem chegava a 4000 exemplares. A mudança para o regime republicano fez o título do periódico se alterar, em 1900, para O Estado de São Paulo. Em 1902, Júlio de Mesquita tornou-se o único proprietário do jornal. Na época, O Estado de São Paulo já era considerado o grande órgão político do Estado. Por volta de 1907 a tiragem do jornal atingira a marca de 35000 exemplares diários. As publicações tinham uma média de 16 a 20 páginas. 0 crescimento do jornal não modificava, no entanto, a sua linha editoral e ideológica, que

\footnotetext{
${ }^{18}$ SODRÉ, Nelson Werneck. História da imprensa no Brasil. Rio de Janeiro: Civilização brasileira, 1966.

${ }^{19}$ SODRÉ, Nelson Werneck. História da imprensa no Brasil. Rio de Janeiro: Civilização brasileira, 1966, 259. SCHWARCZ, Lilia Moritz. Retrato em branco e negro: jornais, escravos e cidadãos em São Paulo no final do século XIX. São Paulo: Companhia das Letras, 1987, 65-72.

${ }^{20}$ FABBRI, Cleber Sebastião. O Estado de São Paulo. In: QUEIROZ, Adolpho e OLIVEIRA, Dennis de (orgs.).Jornais centenários de São Paulo. Piracicaba: Degaspari, 2002.
} 
procurou sempre se vincular às "novas teorias da época", destacando temas como progresso e civilização ${ }^{21}$.

Esses órgãos da imprensa posicionaram-se, claramente, a favor da exposição de Oscar Pereira da Silva e, sobretudo, do próprio quadro, fato nítido, já que muitas notícias citam somente a Fundação de São Paulo, parecendo ser esta a única obra da mostra $^{22}$. Entretanto, sabe-se, pela notícia de O Estado de São Paulo de 31 de dezembro de 1907, que junto da grande tela, muitas outras, de assuntos diversos, também estavam expostas. No entanto, segundo o próprio articulista ${ }^{23}$, apesar da variedade de quadros, os olhos dos visitantes "buscavam a grande tela". Ele justifica dizendo ser natural, já que este era "o maior quadro do certame, pelas proporções, pela importância do assunto, pela execução." Diz ainda: "que o saibamos, ninguém até agora se atreveu a tratar da fundação de São Paulo do modo por que o fez o pincel de Oscar".

Não foram apenas os jornais que divulgaram a tela e a exposição de Oscar Pereira da Silva. Na edição de 25 de dezembro de 1907 da revista A Vida Moderna ${ }^{24}$ (figura1), há uma fotografia da obra acompanhada da legenda: "Reprodução do belíssimo quadro, $A$ fundação de $S$. Paulo, trabalho do distinto artista sr. Oscar Pereira da Silva, em exposição num dos salões do Progredior" ${ }^{\prime 25}$. É importante frisar aqui o que significava ter a imagem de um quadro divulgada em uma revista ilustrada de grande circulação $^{26}$, como esta. Porém, esses instrumentos se mostravam ávidos em exibir ao

${ }^{21}$ SCHWARCZ, Lilia Moritz. Retrato em branco e negro: jornais, escravos e cidadãos em São Paulo no final do século XIX. São Paulo: Companhia das Letras, 1987, p. 72-84 FABBRI, Cleber Sebastião. O Estado de São Paulo. In: QUEIROZ, Adolpho e OLIVEIRA, Dennis de (orgs.).Jornais centenários de São Paulo. Piracicaba: Degaspari, 2002, p. 66-68.

${ }^{22}$ A notícia veiculada no dia 15 de dezembro de 1907, no jornal O Estado de São Paulo, por exemplo, diz: O distinto pintor sr. Oscar Pereira da Silva inaugurou ontem a exposição de sua grande tela - "A Fundação de S. Paulo". Além disso, na nota do jornal O Estado de São Paulo do dia 14 de dezembro de 1907 , só se faz menção ao quadro histórico, como se fosse o único do certame.

${ }^{23}$ Essa notícia foi publicada na coluna Artes e Artistas, e foi assinado com o nome de "R. de L".

${ }^{24}$ A Vida Moderna era uma revista de variedades, que obteve grande sucesso no periodismo paulista. $O$ conteúdo era variado, trazia muitas biografias de figuras relacionadas à Política, Artes e Ciências, e histórico e comentários sobre empreendimentos industriais e comerciais de São Paulo. A revista utilizava recursos iconográficos em praticamente todas as suas páginas. Não usava cores nas páginas internas, mas nas capas há ilustrações coloridas. Matinha laços editoriais com o grupo de O Estado de São Paulo e circulava pelo interior de São Paulo, na capital e em outras capitais. Ver CRUZ, Heloisa de Faria (org.). São Paulo em revista: catálogo de publicações da imprensa cultural e de variedade paulistana 1870-1930. São Paulo: Arquivo do Estado, 1997, p. 265-266.

${ }^{25}$ A vida moderna, 25 de dezembro de 1907, ano II, nos. 29-30.

${ }^{26}$ Segundo Heloisa de Faria Cruz, a tiragem em 1913 era cerca de 12000 exemplares, nesse mesmo ano, em uma edição especial em que a revista foi distribuída para assinantes próprios e assinantes de $O$ Estado de São Paulo a tiragemchegou a 30000 exemplares. A revista circulava pelo interior de São Paulo, na capital e em outras capitais e também na Argentina. Ver CRUZ, Heloisa de Faria (org.). São Paulo em revista: catálogo de publicações da imprensa cultural e de variedade paulistana 1870-1930. São Paulo: Arquivo do Estado, 1997, p. 265. 
mundo a representação de progresso, por isso, as mensagens eram presididas pela ilustração e, mais do que isso, pelos símbolos do progresso. Ana Luiz Martins conclui, assim, que naquela produção, a imagem foi mais eficaz que a letra, já que a fotografia potencializava a informação até então subtraída ao analfabeto e às camadas desfavorecidas. Com isso, sua mensagem atingia indistintamente o letrado, o semialfabetizado e até o analfabeto. Disso resultou um forte apreço da imprensa periódica à veiculação exaustiva de símbolos, configuradores de grupos, classes sociais, partidos, governos e projetos. Dessa maneira, as revistasmaterializaramuma mídia ideal para o país sem tradição de leitura e com grande parte da população analfabeta que, em última instância, podia consumir as imagens ali veiculadas (MARTINS, 2008, 195-196).

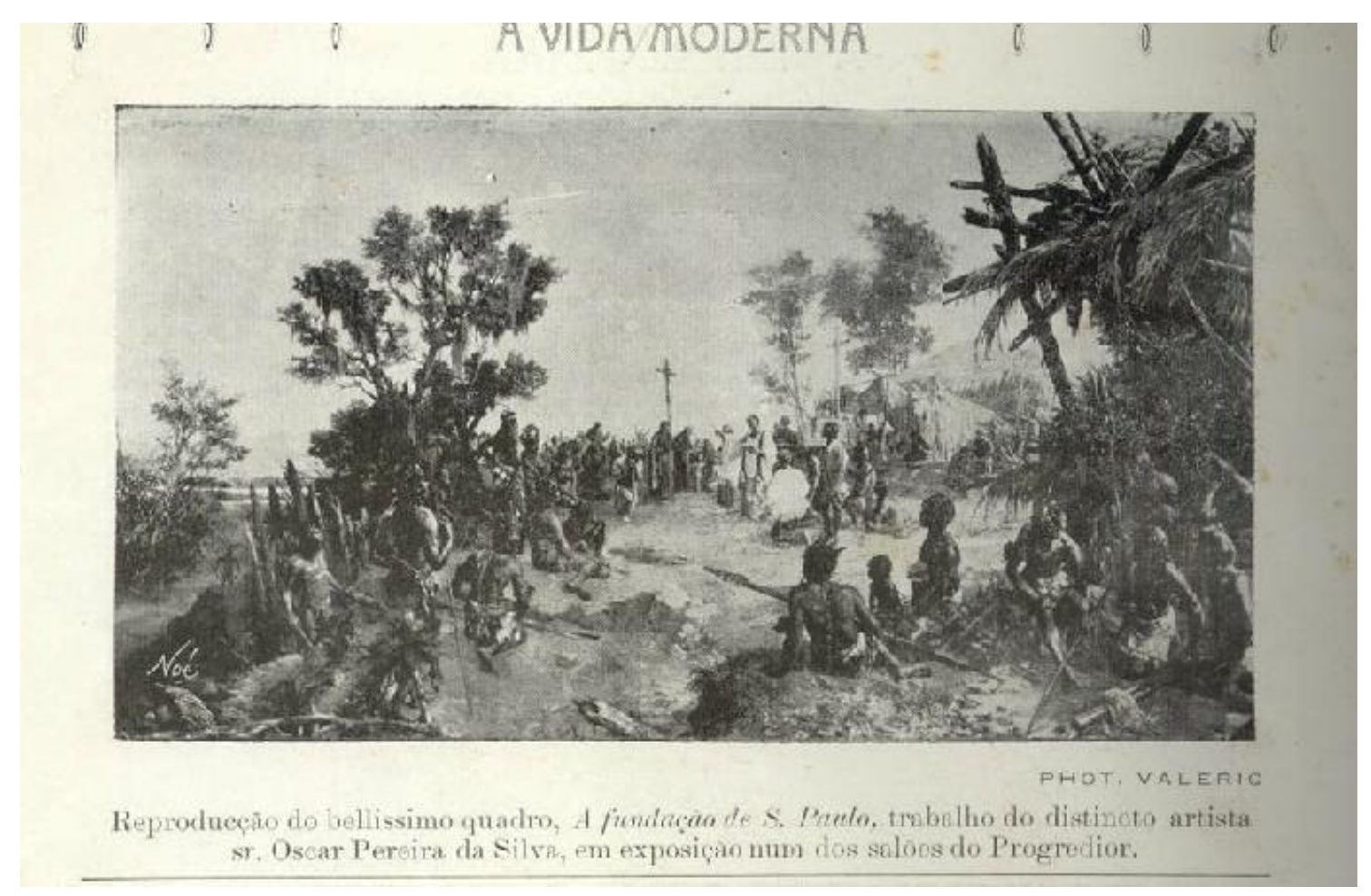

Figura1 - A vida moderna, 25 de dezembro de 1907, II, nos. 29-30.

Ter, portanto, a Fundação de São Paulo divulgada pela revista A Vida Moderna era uma maneira de exponenciar o alcance daquela pintura, tornando-a conhecida do público alvo daquele veículo. Além disso, reafirma o posicionamento favorável que o quadro teria recebido pela crítica impressa, fato que se torna ainda mais evidente quando se observa que, tão logo o quadro foi exposto, veículos da imprensa já iniciavam uma campanha para que o Estado o adquirisse. $O$ mesmo articulista de $O$ 
Estado de São Paulo, citado acima ${ }^{27}$, que havia descrito a exposição, elogiando enfaticamente o quadro histórico, diz que ele "se destaca pela concepção, verdade histórica e, sobretudo, esmero de execução". Diante disso, conclui que:

\begin{abstract}
Ai está um quadro digno de figurar no Museu do Estado. Há nele tudo quanto se pode exigir em arte: inspiração, desenho, técnica, todas as qualidades indispensáveis a um pincel que se propõe a reproduzir na tela um acontecimento histórico, tendo em vista os testemunhos da época, a importância do fato e a intensidade histórica que o mesmo the deve merecer.
\end{abstract}

Na Fundação de S. Paulo não se sabe que mais admirar, se o estudo da natureza, tão vitorioso de compreensão no verdejante plano dos campos de Piratininga entre os rios Tamanduateí e Anhangabaú, se o estudo das figuras, que a luz e atmosfera põem em relevo, proporcionando ao visitante todos os meios de admirar o escrúpulo; o carinho e o "savoirfaire" com que Oscar Pereira da Silva as desenhou, vestiu e tornou, vividas.

(...)

Um quadro como este é digno de todo elogio e tem absoluto direito de ocupar um lugar de honra entre as telas adquiridas pelo governo do Estado ${ }^{28}$.

Essas considerações comprovam a importância da crítica na imprensa e da própria exposição como instrumentos para a venda da obra. Somente telas consideradas dignas de tal merecimento obteriam o prestígio de ocupar um espaço no museu para a exibição pública e os veículos da imprensa eram o principal vetor de construção dessa percepção.

A despeito do enorme valor atribuído aos quadros históricos, no início do século XX, eram raras as instituições museológica no estado de São Paulo. Quando o articulista menciona "Museu do Estado", está se referindo ao Museu Paulista, já mencionado no capítulo 1. Além deste, outro possível destino para a tela de Oscar Pereira da Silva era a recém inaugurada Pinacoteca do Estado de São Paulo ${ }^{29}$. Essas instituições foram criadas com finalidades muito diversas, porém, estavam estreitamente relacionadas ${ }^{30}$. Em ambas, a aquisição de obras era feita, primordialmente, de duas maneiras: doações e compras. No primeiro caso, qualquer

\footnotetext{
${ }^{27}$ O Estado de São Paulo, 31 de dezembro de 1907, assinado por R. de L.

${ }^{28}$ O Estado de São Paulo, 31 de dezembro de 1907, grifos meus.

29 A Pinacoteca do Estado foi inaugurada em uma das salas do Liceu de Artes e Ofícios em 2 de dezembro de 1905, portanto, apenas dois anos antes da tela Fundação de São Paulo ser exposta pela primeira vez.

${ }^{30}$ A relação entre a Pinacoteca do Estado e o Museu Paulista é um tema que será mais profundamente abordado em páginas subseqüentes.
} 
pessoa poderia oferecer uma "dádiva" ao museu, caso achasse pertinente; já o segundo, passava necessariamente pelo crivo da Secretario dos Negócios do Interior.

Sabendo como funcionava o processo de aquisição de quadros, Oscar Pereira da Silva estava ciente da necessidade de sua exposição ser muito bem frequentada, sobretudo pelos políticos que poderiam ser os responsáveis pela compra. Com segmentos importantes da imprensa a seu favor desde a inauguração da exposição, iniciou uma campanha para que o Estado a adquirisse, demonstrando as razões dela merecer um local de destaque.

O encerramento da exposição estava previsto para o dia 31 de dezembro de $1907^{31}$, porém, no dia seguinte a esse, o jornal O Estado de São Paulo publicou uma nota em que dizia que a mostra havia sido muito "concorrida" e muitas pessoas teriam ficado "privadas de ver a grande tela Fundação de São Paulo", motivo pelo qual o artista teria decidido prorrogá-la até o início do ano de $1908^{32}$. A nota afirma ainda que, dentre os visitantes do certame, estava o sr. D. Duarte Leopoldo ${ }^{33}$, bispo de São Paulo. Essa visita merece atenção, pois, como já ficou demonstrado, a relação da obra com o pensamento católico é muito evidente, já que composição formal da tela prioriza a religião como fator de coesão no ato fundador da cidade e condiz, portanto, com o interesse da alta cúpula católica da cidade.

\footnotetext{
${ }^{31}$ A notícia de 31/12/1907 de O Estado de São Paulo afirma que a exposição encerrava-se naquele dia e acrescenta que "os que ainda não foram admirar os trabalhos do bizarro artista, não devem perder o dia de hoje, o último em que lhes será facultada a ocasião poderem admirar vários quadros de um alto valor artístico".

${ }^{32}$ Nota publicada na coluna Artes e Artistas do O Estado de São Paulo de 01 de janeiro de 1908, sem autoria.

${ }^{33}$ Segundo Gomes, durante a Primeira República, no contexto de separação formal entre a Igreja e o Estado, procurou-se alocar em cada diocese um prelado que pudesse ter alguma influência política ou flexibilidade no trato com o novo regime, a fim de organizar o catolicismo no território brasileiro. Para tal intento, a Igreja contou também com a ajuda de uma fração importante de leigos intelectuais com pensamento conservador que foram cooptados para as fileiras do catolicismo, como é o caso de Eduardo Prado, citado no primeiro capítulo. D. Duarte Leopoldo e Silva deve ser incluído dentre as lideranças que procuraram conduzir a Igreja no sentido de atuar junto às elites políticas, para tornar o Brasil uma nação plenamente católica em suas estruturas e leis. Gomes afirma que o Cardeal Joaquim Arcoverde conhecia a capacidade político-administrativa de D. Duarte e, por isso, preconizou sua elevação ao episcopado, já que via o então cônego como alguém capaz de articular uma conveniência amistosa com as autoridades civis, como demonstraram suas correspondências entre os governos civis e eclesiásticos à sua época na diocese paulistana. D. Duarte foi sagrado bispo em Roma no dia 22 de maio de 1904. Tomou posse da diocese de Curitiba no dia 2 de outubro deste mesmo ano, onde permaneceu apenas até 18 de dezembro de 1906, quando foi indicado para assumir a diocese de São Paulo. Ver BENCOSTTA, Marcus Levy Albino. Igreja e poder em São Paulo: D. João Batista Correa Nerya e a Romanização do Catolicismo Brasileiro (1908-1920). Tese de Doutorado FFLCH-USP, 1999. GOMES, Edgar da Silva. Se quisermos que tudo fique como está é preciso que tudo mude. In: XXVI Simpósio Nacional de História ANPUH Anais. São Paulo: ANPUH, 2011.
} 
A primeira vez que a tela foi mencionada na imprensa, o título a ela atribuído foi Batismo de São Paulo ${ }^{34}$. Esta foi a única vez que tal nome foi conferido à obra, além disso, na nota do dia seguinte, o título já aparece alterado. Não é possível, portanto, afirmar com certeza se esse foi um pequeno equívoco do articulista ${ }^{35}$ ou se o pintor decidiu alterar o nome do quadro, atribuindo um maior enfoque à cidade em vez do ato religioso. De qualquer forma, não há como negar que o assunto da tela é o batismo de São Paulo, pois a ação do padre é o de abençoar o local em que seria, posteriormente, edificada a cidade. No entanto, há uma significativa distinção entre os títulos, pois Batismo de São Paulo se remeteria a um, dentre muitos, atos realizados naquele local. Enquanto Fundação de São Paulo demonstra que a tela trata do ato primordial de estabelecimento da urbe, que é feito por meio da ação religiosa. $O$ primeiro título carrega, portanto, um valor diminuto se comparado ao segundo. E como a tela tinha a pretensão de consagrar o artista, era preciso demonstrar, já em seu título, que a imagem representava não um mero ato religioso ocorrido em Piratininga, mas a ação que teria dado origem a São Paulo e seu povo. Com um ou outro título, entretanto, o catolicismo constitui-se no elemento essencial da imagem criada por Oscar Pereira da Silva. Por isso, não é de se estranhar que o próprio arcebispo visitasse a exposição para admirar a obra. Há, contudo, uma outra justificativa para o prolongamento da exposição: a ausência de Jorge Tibiriçá, Presidente do Estado. O convite havia sido formulado pessoalmente pelo artista em 11 de dezembro e a exposição havia sido muito elogiada por segmentos da imprensa, que incitaram o público a visitar o evento. Nada disso, porém, foi suficiente para que o estadista visitasse a mostra e conhecesse a famigerada tela histórica. Oscar Pereira da Silva postergou, então, o encerramento da mostra e insistiu no convite, dirigindo-se novamente ao palácio a fim de solicitar a presença do governante, que prometeu aceder ao convite, como foi relatado na notícia de 01 de janeiro de 1908 de O Estado de São Paulo. Não se sabe, ao certo, se Jorge Tibiriçá cumpriu com sua palavra, pois essa foi a última notícia encontrada sobre essa exposição. No entanto, é possível afirmar que o objetivo pretendido pelo artista não foi atingido, pois a despeito de todo esforço, a tela não foi adquirida pelo Estado imediatamente.

\footnotetext{
${ }^{34}$ A notícia de 14 de dezembro de 1907 do jornal O Estado de São Paulo, citada integralmente no início do capítulo, diz que a exposição inauguraria a tela "Batismo de São Paulo". Porém, pelo que se pode descobrir pela pesquisa, esta foi a única vez que esse título foi atribuído à obra.

${ }^{35}$ Não foi possível identificar a autoria dessa notícia, que foi divulgada na coluna Artes e Artistas do jornal O Estado de São Paulo, porém, sem conter assinatura.
} 


\section{A difícil aquisição}

Oscar Pereira da Silva havia se certificado de realizar uma tela bem elaborada, cumprindo as regras da Academia e seguindo um modelo conhecido e consagrado de Victor Meirelles. Além disso, pautou-se em documentos e descrições de autores considerados legítimos e aliou aos novos estudos que estavam sendo apresentados no IHGSP para compor uma tela digna de ser considerada histórica. Escolheu um local luxuoso, moderno e bem frequentado, situado em uma das principais ruas da cidade para acolher sua exposição. Além disso, foi apoiado por veículos importantes da imprensa local, que não pouparam elogios ao seu quadro histórico. O que teria, então, dado errado no tocante à aquisição pública que ele almejava? Por que Jorge Tibiriçá haveria desprezado o primeiro convitede Oscar Pereira da Silva para a sua exposição? É importante apontar alguns esclarecimentos sobre esse político e algumas hipóteses que podem justificar seu desinteresse pela exposição e pela tela.

Jorge Tibiriçá era neto de João de Almeida Prado (1802-1852) que, deliberadamente, alterou seu sobrenome ${ }^{36}$ para Tibiriçá Piratininga, referindo-se ao patriarca paulista indígena e à denominação nativa de São Paulo. O pai de Jorge, chamado João Tibiriçá Piratininga (1829-1888), era agricultor e dedicou-se a escrever sobre as terras da província de São Paulo e suas estradas de ferro, além de ter sido ativista do partido republicano e participado da Convenção Republicana que ocorrera em Itu em 1873. Jorge Tibiriçá provinha, assim, de uma família de agricultores e republicanos. Nascido em 1855 em Paris, formou-se em ciências físicas pela Universidade de Zurich. Além de dedicar-se à atividade agrícola, fez parte da diretoria da Companhia Mogiana de Estradas de Ferro. Desde cedo participou da política, tendo sido nomeado Governadordo estado de São Paulo em 1890, em substituição a Prudente de Moraes e, logo em seguida, em 1892, foi nomeado Secretário de estado da Agricultura e Obras Públicas, do governo de Bernardinho de Campos. Em 1904 foi eleito Presidente do estado de São Paulo ${ }^{37}$.

\footnotetext{
${ }^{36}$ Segundo Brotero, "Silva Leme atribui a troca do nome do fato de ser cognominado por seus colegas de Coimbra o Tibiriçá Piratininga, que adotou definitivamente. Conhecemos outra versão corrente na família: tais apelidos foram inventados pelo próprio João Tibiriçá em ocasião que deliberou viver incógnito e não dar a conhecer o verdadeiro nome". Ver BROTERO, Frederico de Barros. Descendentes do ouvidor Lourenço de Almeida Prado: notas genealógicas.São Paulo: Escolas Profissionais Salesianas, 1938, p. 68.

37 BROTERO, Frederico de Barros. Descendentes do ouvidor Lourenço de Almeida Prado: notas genealógicas.São Paulo: Escolas Profissionais Salesianas, 1938. SOARES JÚNIOR, Rodrigo. Jorge Tibiriçá e sua época. São Paulo: Companhia Editora Nacional, 1958. FERRARO, Mario Roberto. A
} 
Observar com vagar a atuação de Jorge Tibiriçá na política esclarece o seu desinteresse pelo quadro de Oscar Pereira da Silva. Em primeiro lugar porque a sua relação com a Igreja não era muito amistosa, fato evidenciado quando Jorge Tibiriçá, por meio do Decreto no 104 , de 15 de dezembro de 1890, convocou o Primeiro Congresso e publicou a Constituição que deveria nortear a organização do estado. Neste documento ${ }^{38}$, foi incluído no artigo 65 , parágrafo 8 , a seguinte determinação: "Continua excluída do território do Estado a Companhia dos jesuítas, e proibida a fundação de conventos ou ordens monásticas" ${ }^{39}$. A sua desavença com a Igreja Católica ficou ainda mais explícita quando se envolveu no litígio entre o Clero e o Estado para a restituição da Igreja do Pátio do Colégio - local em que teria ocorrido a fundação de São Paulo. As autoridades eclesiásticas não queriam ceder o edifício, sob a alegação de que ele lhe pertencia. No entanto, o governo de Tibiriçá conseguiu reaver ao Estado a Igreja. Em 1891, o governante decidiu demolir a capela, ideia contra a qual se rebelaram membros eclesiásticos e famílias tradicionais da cidade. Esse impasse adiou a demolição que, entretanto, foi levada a cabo cinco anos mais tarde devido às péssimas condições de manutenção do edifício ${ }^{40}$. Os jesuítas, que já estavam instalados na cidade desde 1893, instalados na igreja de São Gonçalo, foram, assim, definitivamente impedidos de pleitear o retorno à igreja. Como bem concluiu Lima:

Com a exclusão das funções religiosas devido à demolição da torre e da capela, promoveu-se a primeira lacuna nas significações sociais imediatamente associadas ao pátio - o poder da lgreja na organização da cidade colonial e a lembrança de seus fundadores ${ }^{41}$.

gênese da agricultura e da silvicultura moderna no Estado de São Paulo. Dissertação (Mestrado), Escola Superior de Agricultura "Luis de Queiroz", Universidade de São Paulo, Piracicaba, 2005.

\footnotetext{
${ }^{38}$ A Constituição estadual na íntegra pode ser acessada em:

$<$ http://www.al.sp.gov.br/portal/site/Internet/menuitem.e7884dd03f57de2eca76e110f20041ca/?vgnextoid= 58c950d649467110VgnVCM100000590014acRCRD>.

${ }^{39} \mathrm{O}$ artigo 65 trata da declaração de direitos e garantia e estabelece a inviolabilidade dos direitos concernentes à liberdade, à segurança individual e à propriedade, seguindo alguns termos, dentre ele, o parágrafo 8, que trata da Companhia de Jesus. Os jesuítas estavam, entretanto, de volta a São Paulo desde meados do século XIX, pois em 1867 haviam fundado o Colégio São Luiz, em Itu.

40 LIMA, Solange Ferraz de. Pátio do Colégio, Largo do Palácio. Anais do Museu Paulista: História e Cultura Material, São Paulo, , v. 6/7 (1998-1999). Editado em 2003, p. 61-82, p. 69-70.

${ }^{41}$ Idem, p. 70.
} 
A imagem criada por Oscar Pereira da Silva sobre o ato de origem da cidade, que vinculava nitidamente a Igreja ao processo de fundação, colocava em destaque justamente o que Jorge Tibiriçá havia contribuído para esquecer: o papel dos jesuítas.

Além da questão religiosa, é possível indicar outras ações de Jorge Tibiriçá que estavam em dissonância com a proposta da Fundação de São Paulo. Durante a sua gestão na presidência do estado (1904-1908), ele deu prioridade à pauta agrícola. O político, que já havia estado à frente da Secretaria da Agricultura, teve seu secretariado composto em sua totalidade por membros da Sociedade Paulista de Agricultura (SPA) ${ }^{42}$. Durante seu governo, empreendeu trabalho de regularização das terras devolutas e realizou a colonização do território, trazendo imigrantes estrangeiros e dotando-os de pequenos lotes de terra. Estabeleceu, assim, diversas colônias ao longo de estradas de ferro. Em 1907, criou a Diretoria de Terras, Colonização e Administração para tratar de todos os assuntos referentes ao desenvolvimento de uma política de povoamento e colonização. Por meio da Comissão Geográfica e Geológica, deu continuidade ao mapeamento de municípios, como o de Pirassununga e Pindamonhangaba, e realizou expedições que tinham por objetivo conhecer os rios e seus afluentes, além de avaliar a qualidade das terras da região ${ }^{43}$. Invariavelmente, as expedições se deparavam com índios e não eram raros os embates entre eles e os colonos. Um dos incidentes emblemáticos foi o que ocorreu em 1907, quando os índios coroados, ou Kaingangs, teriam atacado canoas e acampamentos em diversas oportunidades, constituindo-se um obstáculo para o estabelecimento dos colonos, sobretudo, por ocasião da implantação da Estrada de Ferro Noroeste do Brasil. Um dos ataques foi noticiado pelo jornal O Estado de São Paulo:

Em informação que publicamos ontem, divulgamos a declaração do engenheiro da Noroeste, sr. Dr. LuisDelphino Ribeiro, confirmando um ataque de índios a uma turma de medidores de terras, que não pertencem, entretanto, ao pessoal daquela via férrea.

Outra comunicação, de caráter oficial, vem confirmar a declaração do referido engenheiro. É um ofício que o delegado da polícia do Rio Preto dirigiu ao sr. Secretário da justiça e da segurança pública, e que abaixo transcrevemos.

"Comunico-vos que na Fazenda dos Patos, desta comarca, lado esquerdo do rio Tietê, várias pessoas foram atacadas pelos índios, cerca das 2 horas da madrugada, de 25

\footnotetext{
42 Dentre os membros do secretariado do governo de Jorge Tibiriçá, que pertenciam à Sociedade Paulista de Agricultura, é possível citar Albuquerque Lins, Secretário da Fazenda; Cardoso de Almeida, Secretário do Interior e Justiça; Carlos Botelho, Secretario da Agricultura.

${ }^{43}$ FERRARO, Mario Roberto. A gênese da agricultura e da silvicultura moderna no Estado de São Paulo. Dissertação (Mestrado), Escola Superior de Agricultura "Luis de Queiroz", Universidade de São Paulo, Piracicaba, 2005.
} 
de julho do corrente ano, quando dormiam em uma mata, onde se achavam a serviço de medição da referida fazenda, resultando mortes e ferimentos(...), ${ }^{, 44}$.

O resultado desses embates entre branco e índios foi a dizimação dos nativos. É possível dizer, assim, que governo de Tibiriçá precisou lidar com a questão do contato, não apenas devido à entrada de imigrantes para trabalhar nas novas colônias que eram criadas ao longo das vias férreas, mas, sobretudo, o contato traumático com os indígenas que representavam um obstáculo à expansão das lavouras a oeste do estado. Contato, portanto, travado de forma violenta e completamente distinto da representação harmoniosa criada por Oscar Pereira da Silva, na Fundação de São Paulo, em que os nativos entendem e assimilam naturalmente a cultura invasora. Dessa maneira, o quadro retoma questões latentes da gestão de Tibiriçá e que ainda estavam em estado de efervescência, já que o problema do embate com os índios não havia se exaurido.

Essas questões ajudam a esclarecer o completo desinteresse de Jorge Tibiriçá pela obra de Oscar Pereira da Silva, fato que se tornou patente quando o político reagiu de maneira indiferente ao convite do artista à sua exposição no Progredior. Passaram-se meses, após a exposição,sem que o governo demonstrasse qualquer intenção de comprar a tela. Diante desse silêncio, o pintor decidiu tomar uma providência, pois, tão logo findou o mandato de Tibiriçá ${ }^{45}$, ele apresentou ao Congresso do Estado um memorial em que propunha a venda da obra. Interessante notar que não foi a primeira vez que o artista utilizou essa estratégia para demonstrar às autoridades a importância de suas pinturas. Em 1900, quando o Desembarque de Pedro Álvares Cabral em Porto Seguro em 1500 ficou pronto, o pintor utilizou-se do mesmo do recurso ${ }^{46}$. Houve, aliás, muitas semelhanças nos mecanismos que o artista dispôs para vender essas duas obras ao Estado.

É possível notar, primeiramente, que as exposições inaugurais foram realizadas próximas da data comemorativa do evento que os quadros representam. A tela com o tema da descoberta foi apresentada ao público em meados de abril e começo de maio, enquanto a do tema da fundação entre dezembro e janeiro. Assim, se houvesse coincidência com um evento comemorativo, essas exposições seriam

\footnotetext{
44 O Estado de São Paulo, 29 de agosto de1907.

${ }^{45}$ No dia 1 de maio de 1904, Manuel Joaquim de Albuquerque Lins assumiu a Presidência do Estado de São Paulo, em substituição a Jorge Tibiriçá.

${ }^{46}$ Tanto para vender a obra Fundação de São Paulo quando Desembarque de Pedro Álvares Cabral em Porto Seguro em 1500, o artista utilizou-se do recurso de enviar uma petição ao Congresso, como está descrito nesse capítulo.
} 
muito propícias. Contudo, nos dois casos, as exposições fracassaram, já que não resultaram na venda imediata dos quadros históricos, situação que forçou o artista a recorrer a outros meios.

O passo seguinte da empreitada relativa à tela do Descobrimento foi o encaminhamento da petição ao Congresso, a fim de que a solicitação fosse feita diretamente ao responsável pelas aquisições de quadros - a Secretaria dos Negócios do Interior. O pedido de venda da tela realizada em 1900 foi feito concomitantemente à exposição, de forma que os políticos pudessem visitar a obra e emitir seu parecer, que não foi favorável à aquisição, como mostra o parecer no 50 , emitido na Sessão ordinária de 26 de julho de 1900 na Câmara dos Deputados:

O pintor brasileiro Oscar Pereira da Silva propõe a venda ao Estado do seu quadro histórico "O primeiro desembarque de Pedro Álvares Cabral" pela quantia de 12:000\$000

A comissão de fazenda e contas, embora não desconheça o valor artístico do referido quadro, é de parecer que não seja aceita a proposta junta, não só porque é muito elevado o preço pedido de 12:000\$000, como ainda porque é prudente não autorizar qualquer despesa extraordinária sem ser conhecido o projeto de orçamento para o próximo exercício

Acresce ainda que, em ocasião oportuna, a Câmara dos Deputados poderá de novo ocupar-se deste assunto.

Sala das comissões, 26 de julho de 1900 - Eugenio Egas, Rubião Junior ${ }^{47}$.

Como foi exposto no parecer, o pedido do artista foi indeferido sob a justificativa do valor requisitado ser muito elevado. É importante que se diga, no entanto, que outros motivos podem ser indicados para o desinteresse dos governantes pelo quadro Desembarque de Pedro Álvares Cabral em Porto Seguro em 1500. O valor artístico e documental da obra era, sem dúvida, merecedor de louros, sobretudo, diante dos festejos do IV Centenário do descobrimento do Brasil - evento que mobilizou grandes recursos dos cofres públicos. Contudo, o episódio escolhido por Oscar Pereira da Silva para a sua representação não contemplou os paulistas, que foram completamente excluídos daquela representação ${ }^{48}$. Vale relembrar que neste momento os regionalismos estavam aflorados e São Paulo procurava reescrever a

\footnotetext{
47 Anais da Câmara dos Deputados, 1900, p. 133, ALESP.

${ }^{48}$ O jornal Correio Paulistano de 03 de maio de 1900 reproduziu a tela e incluiu uma nota explicativa em que dizia que o quadro "representa Cabral desembarcando em terras brasileiras, na paragem que ele denominou Porto Seguro. Depois de celebrada a primeira missa, com assistência da tripulação das caravelas, Cabral não saltou no continente com a bandeira da ordem de Cristo, senão no primeiro de maio (...) Segundo as crônicas, foi nesse dia, primeiro de maio, que se realizara a segunda missa, a que assistiram muitos índios, entre os quais alguns em atitude contrita, por imitação (...)".
} 
história do Brasil, destacando o papel do estado e de seu povo para os eventos considerados mais relevantes do passado nacional. Assim, o quadro de Oscar Pereira da Silva não era em nada atrativo aos governantes paulistas, sobretudo, se comparado a quadros como Fundação de São Vicente ${ }^{49}$, realizado por Benedito Calixto nesse mesmo ano, também no contexto das comemorações do IV Centenário do Descobrimento. O episódio escolhido por Calixto, evidentemente, enquadrava-se melhor às expectativas paulistas, por isso, ainda em 1900 passou a compor, mediante doação, o acervo do Museu Paulista ${ }^{50}$.

Oscar Pereira da Silva, entretanto, não desistiu facilmente. Como o parecer de 1900 indicava que em outra oportunidade o quadro poderia ser de interesse ao Estado, o artista faz uma segunda tentativa no ano seguinte, enviando uma nova petição em que afirmou entender as justas ponderações da comissão, propondo, assim, uma nova oferta:

Tendo porém, o suplicante grande interesse que figurasse no museu ou na galeria de Belas Artes este quadro que relembra um fato histórico de tanta e importância e uma vez que o orçamento vigora conhecido e votado, resolve oferecer a venda novamente 0 quadro pela quantia de 8:000\$000, comprometendo-se mais a doar dois quadros representando indígenas do Brasil e se ainda assim achar a Câmara o preço elevado o artista abaixo assinado sujeita-se à oferta desta ilustrada casa ${ }^{51}$.

Percebe-se, pelo novo requerimento, que o artista desejava enfaticamente vender a tela, por isso, além de abaixar o valor ainda se comprometeu a realizar outras obras. Frente a essa proposta, a Comissão de Fazenda e Contas respondeu que o artista deveria fazer a oferta diretamente ao governo que, se julgasse sensato adquirir a obra, solicitaria, então, o crédito necessário, na ocasião oportuna ${ }^{52}$. Esta

\footnotetext{
${ }^{49}$ Segundo Caleb Faria Alves, Benedito Calixto já tinha planos de realizar a tela Fundação de São Vicente desde 1890, quando o quadro Independência ou morte, de Pedro Américo foi instalado no Museu Paulista. Em 1892, realizou um croqui, que foi remetido à análise de Victor Meirelles. Porém, os fundos necessários para a execução da obra vieram anos mais tarde, com a comemoração do IV Centenário da Descoberta de Brasil. A comissão organizadora das festividades em Santos encomendou a tela a Calixto, a fim de expô-la aos visitantes da cidade durante os festejos. Em seguida, a tela foi doada ao Museu Paulista. Ver ALVES, Caleb Faria. Benedito Calixto e a construção do imaginário republicano. Bauru: EDUSC, 2003, p. 213-214

${ }^{50}$ Fundação de São Vicente foi uma doação feita ao Museu Paulista pela comissão organizadora das festividades do IV Centenário da Descoberta do Brasil em Santos Ver ALVES, Caleb Faria. Benedito Calixto e a construção do imaginário republicano. Bauru: EDUSC, 2003, p. 214.

${ }^{51}$ Petição enviada à Câmara dos Deputados 10 de abril de 1901, ALESP.

52 O documento foi assinado por Eugenio Egas e Pádua Saltes, em 18 de abril de 1901.
} 
ocasião ocorreu no início de 1902 e foi muito noticiada pela imprensa ${ }^{53}$, que não escondeu a satisfação do quadro ter, finalmente, conquistado o merecido espaço no Museu Paulista.

Com mais experiência e ciente das expectativas da elite política paulista, cinco anos mais tarde, o artista não cometeu o mesmo equívoco. Por isso, escolheu o tema da fundação, que era um episódio, além de audacioso, inédito nas grandes representações e que, indubitavelmente, atrairia a atenção daqueles que pretendiam recompor a história de São Paulo, por se tratar o evento inicial. Foram esses os argumentos que Oscar Pereira da Silva procurou ressaltar na petição que enviou em julho de 1908, como foi relatado pelo jornal O Estado de São Paulo. Primeiramente, demonstrou a sua inserção no meio artístico paulistano e, por isso, afirmou ser residente da capital há doze anos, alémde ser professor de desenho do Ginásio do Estado. Após essa introdução, fez, então, o requerimento:

(...) Há muito que o suplicante tem feito diversas exposições de seus trabalhos neste Estado, procurando a custa de todos os sacrifícios perpetuar na tela todos os assuntos que dizem respeito a origem, modas, costumes, progresso e evolução deste glorioso Estado, hoje primeiro da nossa República. Faltava-Ihe, porém, um que preocupava e obrigava a sérios estudos de etnografia, civilização, geológicas e históricas para a fiel execução de um quadro representativo dos mais importantes acontecimento para a terra dos Bandeirantes - A fundação de S. Paulo. Este quadro dá a perfeita compreensão ao estrangeiro e até ao próprio nacional de tão importante fato, quando visitar o nosso museu, a nossa Pinacoteca do Estado. Pintado com esmero ele apresenta quatro metros de comprimento por dois metros de altura, vendo-se 0 acontecimento em que tomaram parte o nobre Anchieta, o padre Manuel da Nóbrega, o padre Manuel Paiva e os índios Caiuby e Tibiriçá em imponente e solene atitude no mesmo lugar em que tem sede hoje o honrado governo do Estado. Em exposição por muitos dias, recebeu os mais sinceros elogios por parte da imprensa desta capital.

Acresce ainda: todos os Estados do Brasil possuem de longa data, o quadro de sua fundação. São Paulo, não adquiriu ainda o quadro de sua fundação, nem tinha sido até agora pintado. Crente que não verá perder-se este seu grande esforço o seu pintor ousa propor a esta respeitável e ilustrada câmara a venda do mesmo pela quantia que oportunamente será fixada.

Respeitosamente vos agradece o deferimento ${ }^{54}$.

\footnotetext{
${ }^{53}$ O Estado de São Paulo publica, em 26 de junho de 1902, uma nota em que diz ser "uma bela aquisição, e atos destes são sempre louváveis, principalmente quando se trata de um artista de talento, como incontestavelmente é Oscar Pereira da Silva". No dia seguinte, o Correio Paulistano afirma que o governo acabara de premiar o esforço de um artista de raro talento e diz que "o seu quadro que hoje pertence à galeria do Ipiranga é um atestado do valor do artista".Da mesma forma O Commercio de São Paulo, em 28 de junho de 1902 diz que o artista "acaba de ver com justiça premiado o seu valor e o seu trabalho".

54 O Estado de São Paulo, 28 de julho de 1908.
} 
Essa petição é muito esclarecedora e comprova as hipóteses aqui avultadas, já que, por meio dela, Oscar Pereira da Silva demonstrou a sua intenção de se firmar como pintor da história paulista. Por isso, procurou evidenciar o esforço e a dedicação que empreendeu para representar em seus quadros não apenas o cotidiano da população, evidenciado pela indumentária e costumes, mas também o progresso e a evolução do estado que ele qualifica como "glorioso". Com essas colocações, o artista queria demonstrar o apreço que tinha perante São Paulo e sua grandeza.

Tendo demonstrado o seu empenho na elaboração de quadro cujos temas eram interesse ao estado de São Paulo, procurou singularizar o episódio da fundação, afirmando que este tema, que há muito lhe preocupava, exigia maior esforço e estudo, já que o evento era mais representativo e, portanto, de maior valia. Outra estratégia que o artista utilizou em seu texto foi a evocação dos emblemáticos bandeirantes, figura que, naquele momento, estava sendo forjada pelos intelectuais como símbolo da grandeza do povo paulista. Pretendeu assim estabelecer uma relação entre a sua obra e o os sertanistas.

Oscar Pereira da Silva fez, ainda, um apelo à função didática que a obra teria, quando exposta em um museu, já que o acontecimento da fundação poderia ser conhecido tanto ao visitante brasileiro quanto ao estrangeiro. Ressaltou a importância do quadro, respaldando-se nos elogios recebidos pela imprensa quando ele esteve em exposição. E, como a tela não estava mais exposta, forneceu a dimensão do quadro e relembrou as figuras que ali estavam representadas. Após esse breve resumo sobre a obra, fez ainda uma provocação ao dizer que todos os estados brasileiros já teriam quadros que representavam a sua fundação- o que, frise-se, de forma alguma procede - e terminou apontando que, a despeito da imensa importância do evento histórico representado, era inédito nas grandes telas, já que nenhum outro artista havia se dedicado a esse assunto.

É evidente que essa petição se apoiou em argumentos deveras mais consistentes do que a que fora apresentada anos antes para o quadro do Desembarque de Pedro Álvares Cabral em Porto Seguro em 1500. Mas, apesar de bem fundamentada, a súplica não obteve a pretendida repercussão. A petição, aliás, parece ter sido esquecida, já que não foi possível encontrar um pronunciamento oficial do indeferimento da requisição. Os Anais da Câmara dos Deputados indicaram que na reunião de 23 de julho de 1908 a petição foi incluída na pauta, porém, a sessão não ocorreu, já que não havia número legal ${ }^{55}$ de deputados na Câmara naquele dia. $\mathrm{O}$

\footnotetext{
${ }^{55}$ Havia apenas 22 deputados reunidos, como é indicado na página 146 dos Anais da Câmara dos Deputados de 1908.
} 
mesmo episódio se repetiu nas três sessões seguintespois o quorum se formou apenas em 28 de julho e, no entanto, a petição não foi mais citada.

Nesse ínterim, ocorreram alguns episódios que podem ter contribuído para o embaraço da venda do quadro. Em 8 de setembro de 1908, teve início, em Viena, o XVI Congresso dos Americanistas. O Brasil foi representado por Manuel de Oliveira $\operatorname{Lima}^{56}$, que afirmou que o país desempenhavaum papel bastante de grande evidência no evento, já que Paul Ehrenreich apresentaria um trabalho de etnografia sobre as tribos do Brasil Meridional e Franz Heger, diretor da seção antropológica e etnográfica do Museu de Viena, falaria sobre as coleções de Loreto $^{57}$ e Natterer ${ }^{58}$, que reuniam objetos de tribos indígenas do Brasil, coleções essas que transformavam o Museu de Viena no "mais rico e completo dos repositórios etnográficos do mundo no tocante à América do Sul"59. Observa-se, assim, que os índios brasileiros estavam em evidência nesse evento científico. O que ninguém esperava, no entanto, é o tamanho destaque que eles ganhariam, como aconteceu.

$\mathrm{Na}$ sessão de 14 de setembro, os participantes do Congresso foram surpreendidos pelo pronunciamento de Albert Frič, que denunciou os colonizadores brasileiros e europeus pelo extermínio de tribos indígenas nas recém criadas colônias ao sul do Brasil. Disse que a população nativa estava sendo dizimada por atos de escravidão, rapto e assassinato, já que as terras vendidas para especuladores estavam sendo "limpas de índios hostis". Antes de terminar o seu discurso, ele fez um esforço para obter apoio oficial do Congresso em favor dos índios perseguidos do Brasil. A sessão teve continuidade com Eduard Seler, do Museu de Berlim, que procurou abrandar as denúncias que haviam sido feitas. Na sessão da tarde, o presidente do Congresso, Wilhelm Freiherr von Weckbecker, disse que, embora a causa do índio atraísse a simpatia dos americanistas, a proposta sugerida por Frič pertencia à esfera governamental, e não a um congresso científico, desse modo,

\footnotetext{
${ }^{56}$ As quatro sociedades científicas brasileiras representadas no Congresso eram: o IHGB, a Sociedade de Geografia do Rio de Janeiro, o Instituto Arqueológico e Geográfico de Pernambuco e o Centro de Ciências, Letras e Artes de Campinas. Ver STAUFFER, David Hall. "Origem e Fundação do Serviço de Proteção aos Índios (1889-1910)" trad. de J. Philipson. Revista de História, , São Paulo, no43, 1960, p. 165.

${ }^{57}$ Segundo Oliveira Lima, Franz Heger havia estado no Rio de Janeiro para adquirir por conta do Governo austríaco a coleção particular reunida pela Baronesa de Loreto. OLIVEIRA LIMA, Manuel de. Obra seleta. Rio de Janeiro: Instituto Nacional do Livro, 1971, p. 495.

58 Segundo Oliveira Lima, a contribuição capital para a importância do Museu de Viena se dava, sobretudo, pela "abundantíssima coleção que em dezoito anos de peregrinações pelo nosso país, em boa parte na sua região amazônica, organizou o naturalista Johann Natterer. Consta de 2500 números o legado científico, somente no domínio etnográfico proveniente de mais de 80 tribos indígenas, do grande viajante". OLIVEIRA LIMA, Manuel de. Obra seleta. Rio de Janeiro: Instituto Nacional do Livro, 1971, p. 495.

${ }^{59}$ OLIVEIRA LIMA, Manuel de. Obra seleta. Rio de Janeiro: Instituto Nacional do Livro, 1971, p. 495.
} 
considerou o assunto encerrado ${ }^{60}$. A notícia sobre esse episódio publicada no Jornal do Commercio $^{61}$, do Rio de Janeiro dizia o seguinte:

O Congresso dos Americanistas aprovou por aclamação a proposta do Delegado Fritsch (sic), de enviar-se ao Governo do Brasil uma representação, pedindo que seja abolida a escravidão de índios no estado de Santa Catarina ${ }^{62}$.

Segundo Stauffer, o pronunciamento de Frič foi criticado pela imprensa alemã, bem como pelos cientistas presentes no Congresso, como Ehrenreich, Seler e von Weckbecker. A nota veiculada na imprensa brasileira, no entanto, deixa clara a denúncia. Segundo Manuela Carneiro da Cunha, esta teria sido a primeira vez que o Brasil foi publicamente acusado de massacrar os índios ${ }^{63}$. Esse debate culminou com uma outra polêmica sobre a situação dos nativos brasileiros, ensejada pela publicação de A Antropologia do estado de São Paulo de Hermann von Ihering, diretor do Museu Paulista. Este artigo não era inédito, já que havia sido apresentado na Exposição de Saint Louis, nos EUA, em 1904, e publicado em inglês no jornal O Estado de São Paulo, em 1906. Porém, a versão traduzida para o português foi a veiculada no volume VII da Revista do Museu Paulista que, segundo Stauffer, foi distribuída na segunda quinzena de setembro de 1908, portanto, chegou ao público brasileiro nos dias seguintes à notícia do protesto de Frič em Viena. Ao tratar da resistência que os Kaingangs representavam para o "progresso" de São Paulo, von Ihering escreveu:

Os atuais índios do estado de São Paulo não representam um elemento de trabalho e de progresso. Como também nos outros estados do Brasil, não se pode esperar trabalho sério e continuado dos índios civilizados e como os Kaingangs selvagens são um empecilho para a colonização das regiões do sertão que habitam, parece que não há outro meio, de que se possa lançar mão, senão o extermínio ${ }^{64}$.

Essa declaração incitou uma verdadeira querela, já que diversos grupos da sociedade civil, notadamente acadêmicos e positivistas, rechaçaram o posicionamento

\footnotetext{
60 STAUFFER, David Hall. "Origem e Fundação do Serviço de Proteção aos Índios (1889-1910)" trad. de J. Philipson. Revista de História, USP, São Paulo, 37, 1959. GAGLIARDI, José Mauro.O indígena e a República. São Paulo: HUCITEC: Editora da Universidade de São Paulo: Secretaria do Estado da Cultura, 1989.

${ }^{61}$ A nota veiculada na coluna Austria-Hungria e não contém assinatura.

62 Jornal do Commercio, 16 de setembro de 1908.

${ }^{63}$ CUNHA, Manuela Carneiro da.Os direitos do índio.São Paulo: Editora Brasiliense, 1987, p. 78-79.

${ }^{64}$ Revista do Museu Paulista, p. 215.
} 
do diretor do Museu Paulista. A primeira reação foi a de Silvio de Almeida, que publicou na coluna "Divagações" do jornal Estado de São Paulo uma resposta ao artigo em que depreciava o posicionamento de von Ihering, afirmando que ele sugeria o alvitre impiedoso da dizimação dos indígenas, reduzindo à matança em nome da civilização. Além disso, fez ataques pessoais ao cientista alemão, declarando que seu filho, Rodolpho von Ihering, não se importaria com a exterminação de dez mil indígenas de São Paulo, contanto que os despojos fossem recolhidos ao Museu Paulista, para que pudesse alimentar seus estudos antropológicos. Silvio de Almeida posicionou-se a favor da miscigenação ao dizer que o cruzamento dos europeus com os nativos teria como resultado "produtos verdadeiramente superiores", como era o caso de muitas famílias que descenderam de Tibiriçá, de Piqueroby e tantos outros ${ }^{65}$. Em apoio a Silvio de Almeida, Horta Barbosa enviou uma carta aberta, divulgada no jornal Cidade de Campinas ${ }^{66}$, contra o que ele chamou de "inqualificável e bárbara teoria de um cientista estranho aos nossos sentimentos e aos nossos melhores preconceitos". Disse ainda ser falsa a declaração de que "não se pode esperar trabalho sério e continuado dos índios civilizados" e evocou Couto de Magalhães e Gonçalves de Magalhães para provar seu ponto de vista.

No dia 20 de outubro, foi publicada no O Estado de São Paulo a defesa de von Ihering, na qual afirmava que o índio do Brasil meridional não representava uma "raça forte" e enérgica e não se podia esperar dele um trabalho penoso e assíduo. Disse que, como homem, via com simpatia o coroado do Rio do Peixe ${ }^{67}$, mas que como cidadão, não podia consentir que a marcha da cultura devesse parar "perante as flechas do índio" e que, certamente, a vida do sertanejo e do colono valia mais do que a do bugre. Então, concluiu que a sorte dos indígenas era certa: "em parte aceitarão a nossa cultura, em parte continuarão nossos inimigos e, como tais, sucessivamente desaparecerão". No mesmo dia em que sua resposta foi publicada no jornal, von Ihering apresentou uma conferência no IHGSP, em que respondeu às denúncias de Frič, procurando desqualificá-lo como cientista, além de demonstrar que as suas acusações haviam sido infundadas. Afirmou, ainda, que no estado de São Paulo não se conhecia a "instituição dos bugreiros". Interessante notar que von lhering citou novamente o polêmico excerto de seu artigo, mas acrescentou uma nota na qual

\footnotetext{
${ }^{65}$ O Estado de São Paulo, 12 de outubro de 1908.

66 Segundo Stauffer, a carta de protesto de Horta Barbosa foi publicada no jornal Cidade de Campinas, logo depois de ter sido escrita em 12 de outubro. Em 11 de novembro de 1908 ela foi republicada no Jornal do Commercio, do Rio de Janeiro.

67 A expedição do Rio do Peixe provocou diversos embates com os índios chamados "coroados", que eram vistos por Ihering como nativo que seria refratário à incorporação à cultura brasileira.
} 
explicava que, ao falar de extermínio dos índios, referia-se "àqueles que são um verdadeiro empecilho à expansão da nossa cultura e isto no caso de complicações e assaltos"68.

Os protestos contra von Ihering não cessaram, ao contrário, tomaram proporções ainda maiores com suas novas declarações, que fizeram com que outras pessoas e instituições procurassem demonstrar seu repúdio àquelas ideias ${ }^{69}$. O Museu Nacional, por exemplo, levantou um protesto formal contra o "extermínio milhares de seres humanos, filhos legítimos deste país"70. Afirmou que o indígena, em geral, era inteligente, industrioso, com grande capacidade de trabalho, porém, que ele não estava amparado pela lei. Essas novas manifestações não calaram von Ihering, que afirmou ${ }^{71}$ nunca ter pregado o "extermínio de índios", demonstrando apenas a diferença entre os indígenas "semi-civilizados" e "índios ferozes", e queestes seriam absolutamente refratários a qualquer a qualquer tentativa de integração, além de viverem em guerra cruel e continua com a população vizinha. Declarou ainda que em São Paulo os "bugreiros" eram criminosos e, com isso, contradisse sua própria declaração anterior, em que afirmava que aquele estado não conhecia sua instituição. Reiterou seu argumento que os índios não representavam um elemento de progresso e de trabalho, concluindo que:

O protesto dirigido contra mim por causa do extermínio dos Coroados é absurdo, visto que este extermínio dos Coroados se efetua ano por ano, e pouco tempo há de decorrer até que o último Coroado bravio tenha sucumbido nesta luta desigual contra a civilização moderna. Não é contra a minha pessoa, mas contra o sistema oficial, até agora observado em relação aos indígenas, que tais protestos se devem dirigir ${ }^{72}$.

Depois desse artigo, von Ihering não mais se manifestou, apesar da polêmica ter se estendido até pelo menos o início de $1909^{73}$, fazendo com que a Sociedade

\footnotetext{
${ }^{68}$ Correio Paulistano, 29 de outubro de 1908.

${ }^{69}$ Além do Museu Nacional, outras instituições se manifestaram, como a lgreja Positivista, no dia 03 de novembro de 1908, no Jornal do Commercio; o Centro de Ciências, Letras e Artes, por meio da fala de Vicente Melillo, no dia 24 de outubro; a Associação de proteção e Auxílio aos Selvícolas do Brasil, por meio do protesto de Leolinda Daltro lido na sessão de 9 de dezembro. Ver STAUFFER, David Hall. "Origem e Fundação do Serviço de Proteção aos Índios (1889-1910)" trad. de J. Philipson. Revista de História, São Paulo n. 44 e 46, 1960 e 1961.GAGLIARDI, José Mauro.O indígena e a República. São Paulo: HUCITEC: Editora da Universidade de São Paulo: Secretaria do Estado da Cultura, 1989.

${ }^{70}$ Esse protesto foi publicado no Jornal do Commercio em 6 de dezembro de 1908.

${ }^{71}$ Jornal do Commercio, 15 de dezembro de 1908.

72 Jornal do Commercio, 15 de dezembro de 1908.

73 Teixeira Mendes disse em artigo publicado no Jornal do Commercio, em 16 de dezembro, que não era necessário optar pelo extermínio do índio ou do sertanejo, mas que deveria haver humanidade e justiça para todos. Houve também um telegrama do coronel Cândido Mariano da Silva Rondon enviado a João
} 
Nacional de Agricultura se pronunciasse, sugerindo que o governo federal assumisse a responsabilidade pela incorporação dos índios à sociedade brasileira através de meios pacíficos. Segundo Manuela da Carneiro da Cunha, foi na esteira desse movimento de opinião pública sem precedentes sobre a questão indígena, que seria, posteriormente, criado o Serviço de Proteção ao Índio (SPI), em 1910 ${ }^{74}$.

O que se pode depreender de toda essa querela era a conturbada situação em que estava envolvido o diretor do Museu Paulista e que, certamente, constituía um obstáculo para o projeto de aquisição da tela desejado por Oscar Pereira da Silva. Como vender um quadro que representa o encontro pacífico de índios e europeus para uma instituição cujo diretor é tido como defensor do extermínio indígena? Qual a importância dessa tela para o intelectual que escrevera que os índios de São Paulo "nem atualmente, nem tão pouco no tempo da descoberta não possuíam grau de civilização que se pudesse dizer mais elevado, nem mesmo a influência de outros elementos de maior cultura" ${ }^{\prime 75}$ ? De fato, toda essa polêmica teve uma repercussão para o quadro, já que, depois de enviada a petição ao Congresso do Estado, em julho de 1908, ele deixa de ser citado em jornais e revistas, caindo no esquecimento por mais de um ano.

Após esse longo período de dormência, Oscar Pereira da Silva decidiu tomar providências para que sua obra voltasse a ganhar destaque, assim, realizou uma nova exposição, em agosto de 1909. Tendo em vista que a questão indígena era ainda uma celeuma, decidiu ressaltar o viés religioso do seu quadro, sendo assim, achou adequado exibi-lo numa das salas do antigo Palácio Episcopal, situado à rua do Carmo, em São Paulo ${ }^{76}$. A repercussão dessa atitude ficou patente na única nota encontrada no jornal $O$ Estado de São Paulo sobre o evento, já que divulgou a visita do D. Joaquim Arcoverde, cardeal-arcebispo do Rio de Janeiro, dizendo, ainda, que ele fez "ao distinto artista grandes elogios pelo seu belo quadro"77. Outro argumento que reforça essa hipótese é o fato da tela ter sido divulgada em uma revista católica intitulada Santa Cruz.

Batista de Lacerda, diretor do Museu Nacional, em que tornava pública sua indignação a respeito da proposta de von Ihering, publicado no Jornal do Commercio em 11 de fevereiro de 1909.

${ }^{74}$ CUNHA, Manuela Carneiro da. Os direitos do índio.São Paulo: Editora Brasiliense, 1987, p. 78-79.

${ }^{75}$ A Antropologia do Estado de São Paulo. Revista do Museu Paulista, São Paulo, vol. VII, 1907,p. 246.

76 Trata-se da atual sede do Museu da Cidade de São Paulo, antiga residência da Marquesa de Santos, depois Palácio Episcopal.

${ }^{77}$ O Estado de São Paulo, 02 de Agosto de 1909. 
Segundo na Luiza Martins, ao contrário da pretensão republicana, a separação da Igreja e do Estado fez com que o catolicismo recrudescesse, sendo os periódicos um instrumento para seu proselitismo. Além disso, a laicização era amparada por teorias científicas naturalistas, contestadoras das verdades tradicionais da Igreja, e pela ascensão ao poder de positivistas, maçons e liberais agnósticos. Diante disso, as autoridades eclesiásticas lançaram-se numa campanha de recristianização, com vistas a propagar o catolicismo e, sobretudo, combater o anticlericalismo de intelectuais de todos os matizes, investindo na conquista das massas populares. Nesse contexto, as revistas dos primeiros anos da República, embora sem inscrever-se na rubrica de publicação religiosa, constituíram-se em porta-vozes da lgreja ${ }^{78}$.

Um periódico de grande importância foi a Santa Cruz, iniciativa dos salesianos do Liceu Sagrado Coração de Jesus, que contavam, inclusive, com gráfica própria. Com o passar dos anos, ela se tornou uma revista de prestígio, dispondo de colaboradores conceituados, cobrindo matérias de interesse para a vida cultural, sem se desvincular das propostas católicas. Dessa maneira, entremeada pelas mensagens de propósitos religiosos, a Santa Cruz divulgava extensas matérias que, normalmente, em suas concorrentes, limitavam-se a poucas linhas. Um caso exemplar eram as matérias dedicadas às exposições de pintura, que começaram a ganhar espaço no cotidiano paulistano (MARTINS, 2001: 362-364).

No exemplar de outubro de 1909 da revista Santa Cruz foi reproduzido o quadro de Oscar Pereira da Silva, seguido da legenda: "Importante tela do ilustre pintor paulistano Oscar Pereira, representando a fundação de São Paulo"79 (figura2). Nas páginas subsequentes, há um artigo ${ }^{80}$ dedicado ao artista e a sua obra, no qual os elogios não foram poupados. $O$ articulista descreveu o quadro, ressaltando as figuras de Manuel da Nóbrega e Anchieta, além de apontar suas qualidades artísticas e históricas.

\footnotetext{
${ }^{78}$ MARTINS, Ana Luiza. Revistas em revista:Imprensa e práticas culturais em tempos de República. São Paulo: Edusp, Fapesp, Imesp, 2001, p 355-356.

${ }^{79}$ Santa Cruz, São Paulo, ano X no. 1, Outubro de 1909, p. 6.

${ }^{80}$ Assinado por Russel, no dia 02 de outubro de 1909.
} 


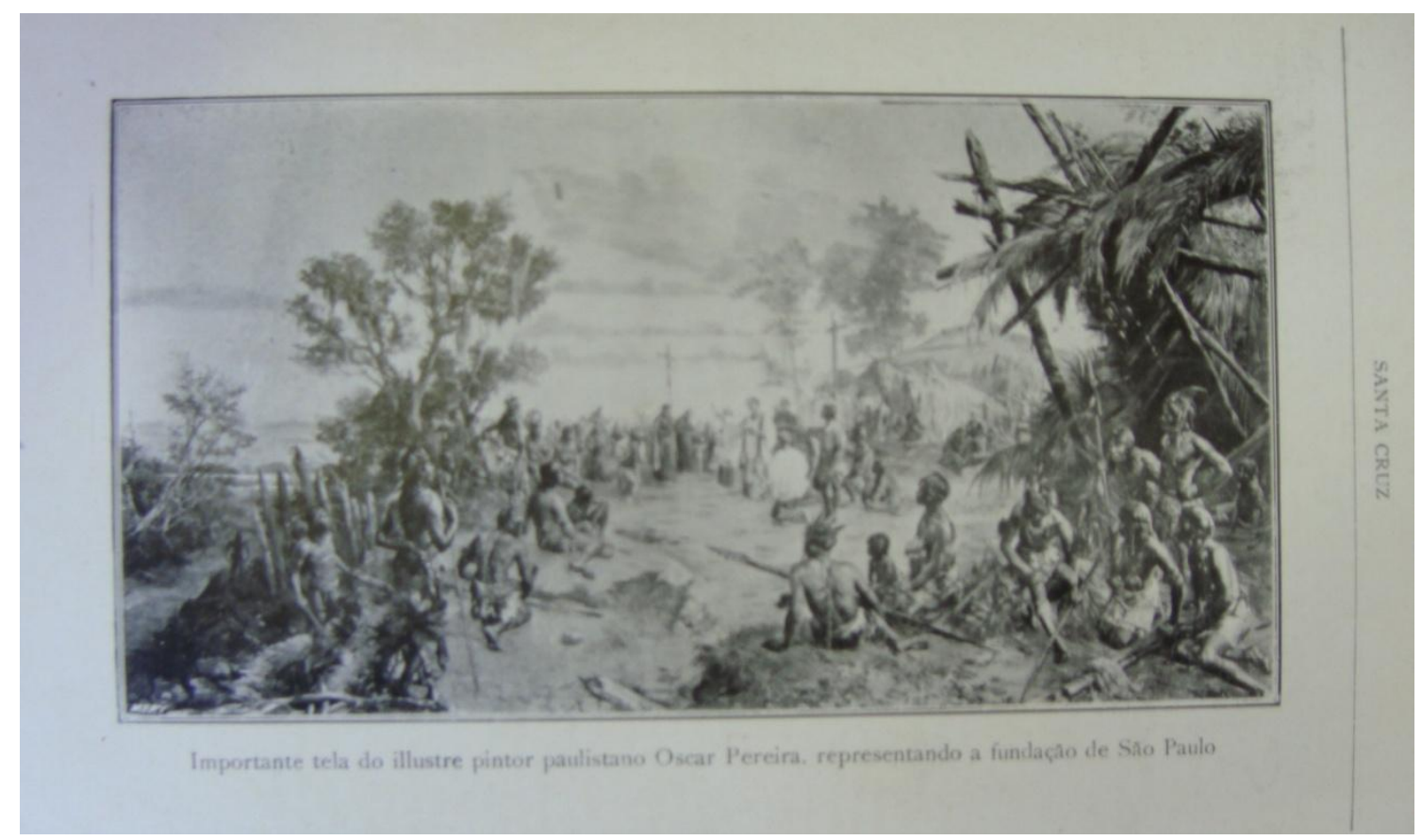

Figura 2 - Santa Cruz, São Paulo, ano X no. 1, Outubro de 1909, p. 6

Sobre a exposição que ocorrera no Palácio Episcopal, o jornal Correio Paulistano publicou uma extensa notícia ${ }^{81}$. Primeiro, relatoua trajetória da obra, afirmando que o artista havia despendido cerca de dois anos na sua concepção e fatura, que ela havia sido exposta no "Progredior" e que a crítica havia se prenunciado a seu favor. No entanto, desde o primeiro evento, o quadro estivera conservado no ateliê do artista à espera de "uma compra razoável, atenta a sua valia artística". Acrescentou que, até aquele momento, infelizmente, o artista não havia encontrado um comprador para o seu quadro e, "vendo que ele ficaria injustamente esquecido (...) deliberou expô-lo novamente, para que atraísse a atenção do governo estadual, visto que naturalmente se destina a ocupar um lugar na Pinacoteca do Estado.".

Após essas breves colocações, o articulista relatou, passo a passo, as etapas de elaboração do quadro, demonstrando as dificuldades pelas quais o artista havia passado. Afirmou ser a Fundação de S. Paulo "um quadro histórico de composição, cuja elaboração árdua e difícil tomou muito tempo ao seu autor". Em primeiro lugar, porque ele teve que realizar um aprofundado estudo, consultando "velhos cronistas coevos" para se elucidar acerca da localidade em que se passou a ação, bem como o caráter dos seus personagens. Precisou ir ao Museu Paulista a fim de recompor trajes, armas, construções. Depois disso, fez sucessivos esboços até determinar a disposição

\footnotetext{
${ }^{81}$ Correio Paulistano, 04 de agosto de 1909. A notícia foi publicada na coluna Registro de Arte, porém, o artigo não está assinado.
} 
definitiva dos elementos na tela. Em seguida, começou a fase de estudo que, segundo o articulista, era o "o período mais árduo e laborioso da tarefa", sobretudo, por não haver modelos, tendo o artista de se servir de manequins e imaginar neles a expressão. Teve, ainda, de reunir em seu ateliê acessórios e objetos, que "Ihe custaram boa soma de dinheiro". Depois, estudou também a paisagem e, para que houvesse uma afinidade entre fundo e figuras, teve de transportar a tela para o ar livre. Após demonstrar as fases de elaboração da obra, o articulista demonstrou também que a tela era de "indiscutível merecimento artístico, fosse pelo desenho, pela composição de suas figuras, pela iluminação, pelo colorido e pela perspectiva. Conclui, então, que:

Pintar uma tela dessas num meio artístico como o nosso, tão desfavorecido de incentivos orça por um verdadeiro heroísmo sem nome porque, além de serem avultadas a despesas, que o artista faz para esse fim surge diante dele o fantasma de uma entre mil probabilidades de não encontrar para seu trabalho, futuramente, alguém que o compre compensando-o de tantos esforços, de tantas fadigas de tantos dissabores ${ }^{82}$.

Como era esta situação insatisfatória em que Oscar Pereira da Silva se encontrava, o articulista procurou ao longo de todo o texto, instigar o governo estadual a comprar o quadro. Por isso, afirmou que o seu desejo era ver a tela figurar na Pinacoteca do Estado, pois ela "merece bem esse lugar". No fim do artigo, o autor ainda rogou a benesse: "Oxalá que o pintor do quadro Fundação de S. Paulo alcance uma justa compensação aos esforços que despendeu para pinta-lo"83.

A fim de obter a propalada compensação, Oscar Pereira da Silva utilizou-se de todos os recursos que estavam ao seu alcance.Assim, outubro de 1909 foi um mês agitado e decisivo para os destinos da tela. Primeiro, o artista recebeu a visita do Secretário do Interior, Carlos Guimarães, em seu ateliê, ocasião em que o político emitiu francos elogios aos trabalhos do pintor, em especial, ao grande quadro histórico Fundação de São Paulo, segundo foi relatado pelo jornal O Estado de São Paulo ${ }^{84}$. Transcorrido alguns dias, a justificativa da ilustre visita foi evidenciada, já que em 05

\footnotetext{
${ }^{82}$ Correio Paulistano,04 de agosto de 1909.

${ }^{83}$ Correio Paulistano, 04 de agosto de 1909.

${ }^{84}$ O Estado de São Paulo, 05 de Outubro de 1909
} 
de outubro ${ }^{85}$, foi lida e posta em discussão na Câmara dos Deputados uma petição que o pintor havia enviado ao Congresso do Estado.

Exmos. Srs. Presidente e mais Membros do Congresso Legislativo do Estado de S. Paulo

Oscar Pereira da Silva, abaixo assinado, artista nacional residente ha longo tempo nesta Capital, dirige-se respeitosamente a VV.EE., para oferecer à aquisição do Estado o seu quadro histórico, de grandes dimensões - "A fundação de S. Paulo".

O suplicante, é claro, sente-se constrangido dizendo sobre a própria obra; e, por isso, não se deterá em considerações a respeito do seu valor, que tem sido apreciado acordemente por quantos senadores, deputados, artistas, críticos e jornalistas tem tido ensejo de o ver.

Limita-se, por isso, a juntar os dizeres unânimes da imprensa, além do parecer autorizado do grande pintor francês, Mr. Gabriel Biessy, deixado na sua passagem por S. Paulo.

VV.EE., Srs. Membros do Congresso de S. Paulo, poderão, com elementos de conhecimento próprio do quadro referido, assim como os que resultam das opiniões insuspeitas que ora se thes oferecem, em anexo, julgar do merecimento do quadro - "A fundação de S. Paulo", determinando a aquisição dele para a Pinacoteca do Estado, que é o que espera o suplicante da sabedoria e da Justiça dos representantes do povo na assembléia legislativa.

O quadro tem as dimensões de $3.50 \mathrm{~m}$ por $2.20 \mathrm{~m}$, sendo de Rs. 18:000\$ (dezoito contos de réis) o preço pelo qual o suplicante transferirá ao Estado essa obra a que tem consagrado perseverante trabalho e o melhor dos seus esforços.

Assim, de VV.EE., com o deferimento,

E.R.M ${ }^{86}$.

Um importante dado a ser considerado é que, no mesmo dia 05 de outubro de 1909, Oscar Pereira da Silva tornou-se membro efetivo do Instituto Histórico e Geográfico de São Paulo ${ }^{87}$, fato que certamente não foi contingente, já que essa era uma das instituições responsável por escrever a história do Brasil por um olhar paulista $^{88}$. Durante toda a primeira República, o IHGSP gozou de grande prestígio, inserindo-se na órbita do poder político dominante do Estado. Era uma entidade inteiramente integrada ao mundo oficial de São Paulo e de inequívocas ligações com o poder regional, que pode ser medida pelos fartos recursos que os sucessivos

\footnotetext{
${ }^{85}$ Diário Oficial do Estado de São Paulo, 06 de outubro de 1909 e Anais da Assembleia Legislativa do Estado de São Paulo, livro 207, p. 208.

${ }^{86}$ Petição enviada por Oscar P. da Silva ao Congresso do Estado5 de outubro de 1909, APESP

${ }^{87}$ Revista do Instituto Histórico e Geográfico de São Paulo, São Paulo, vol. XIV, 1909, p. 464.

${ }^{88}$ A pretensão do IHGSP fica clara já no primeiro número de sua Revista, em 1895, que diz "a história de São Paulo é a própria história do Brasil".
} 
governos a ela destinavam. Ademais, do conjunto de membros sobressaía um núcleo de origens e laços sociais muito bem definidos, constituídos de indivíduos beneficiários das fortunas já consolidadas na expansão capitalista de São Paulo e que vinham ocupando os mais importantes espaços de poder político ${ }^{89}$. Portanto, fazer parte do quadro de associados era certamente, uma maneira de inserir-se nos meios políticos e intelectuais paulistas.

A petição teve ainda de percorrer longo trâmite burocrático na Câmara dos deputados. Após terem transcorrido nove dias desde o pedido feito por Oscar Pereira da Silva, foi decidido, na $37^{\text {a }}$ sessão ordinária em 14 de outubro ${ }^{90}$, que o Secretário dos Negócios do Interior era a pessoa responsável que deveria enviar um parecer sobre a obra para que a Comissão de Fazenda e Contas pudesse se manifestar sobre a conveniência da aquisição.

O último indício encontrado sobre esse processo nos Anais da Assembleia Legislativa é o da $57^{\text {a }}$ sessão ordinária em 26 de novembro, em que foi dito apenas que o Secretário do Interior havia enviado as informações solicitadas sobre uma proposta para aquisição, pelo Estado, do quadro histórico $A$ fundação de $S$. Paulo, à Comissão de Fazenda, sem, no entanto, relatar se o parecer havia sido favorável.

O que permitiu esclarecer o resultado dos trâmites foi um papel manuscrito, datado de 23 de novembro de 1909, que foi encontrado junto a outros documentos do processo:

\section{Exmo.. Sr. 1‥ Secretario da câmara dos deputados}

Respondendo ao oficio de V. Exa., no. 162, de 18 de outubro ultimo, em que me pede emita opinião sobre uma proposta para a aquisição, pelo Estado, do quadro histórico "A fundação de S. Paulo" do artista Oscar Pereira da Silva da qual trata o parecer no. 62 dessa Camara, que se originou enviar-me, tenho a honra de declarar a V. Exma. que de presente não disponho dos necessários elementos para bem ajuizar desse trabalho, parecendo-me, entretanto, que seria de boom alvitre consignar o Congresso na lei orçamentária a verba necessária para a aquisição de quadros de reconhecido valor, firmados por competentes de esta, para a nossa Pinacoteca ${ }^{91}$.

\footnotetext{
89 FERREIRA, Antonio Celso. A epopéia bandeirante: letrados, instituições, invenção histórica (1870 1940). São Paulo: Editora Unesp, 2002, p. 94-101.

${ }^{90}$ Diário Oficial do Estado de São Paulo, 15 de outubro de 1909; Anais da Assembleia Legislativa do Estado de São Paulo, livro 207, p. 280.

${ }^{91}$ Parecer manuscrito do Secretário dos Negócios do Interior, 23 de novembro 1909, APESP
} 
É possível concluir, portanto, que o parecer foi favorável à aquisição, que se justificava pelo fato do quadro ter "reconhecido valor", como diz o Secretário dos Negócios do Interior. Não foi encontrada, no entanto, nenhuma notícia veiculada nos jornais a respeito dessa decisão. O documento que permite comprovar essa hipótese é uma carta enviada por Oscar Pereira da Silva ao Secretário de Interior em 17 de Fevereiro de 1910, na qual pede para que seja designado o local onde o quadro, adquirido pelo governo do Estado, deveria ser colocado.

\section{Museu Paulista ou Pinacoteca do Estado?}

O fato do artista questionar o destino da tela, nos leva a crer que ainda não havia um consenso a esse respeito, apesar do próprio Secretário do Interior ter indicado a Pinacoteca como local propício para o recolhimento da obra. Foram divulgadas as mais inusitadas suposições, como a da revista Santa Cruz, que disse que o quadro seria comprado para o Salão Nobre do novo Couraçado São Paulo ${ }^{92}$. Até mesmo a imprensa ${ }^{93}$ dividia opiniões a respeito do destino a ser dado à grande tela de Oscar Pereira da Silva: Museu Paulista ou Pinacoteca do Estado de São Paulo? A escolha de qual instituição deveria recebê-la não era apenas uma questão do local onde a obra estaria exposta, mas qual sua característica, afinal, estaria sendo priorizada.

O Museu Paulista foi criado com as funções de memorialda independência e museu de história natural, seguindo o modelo dominante da segunda metade do século XIX. Como apontou Meneses, o caráter enciclopédico da instituição derivava de uma concepção da natureza como síntese e paradigma, consequentemente, havia espaço também para a história ${ }^{94}$. Dessa maneira, mesmo tendo como diretor um zoólogo e com a maior parte de seu acervo dedicado à história natural, a

\footnotetext{
${ }^{92}$ Revista Santa Cruz, São Paulo, ano X, outubro de 1909, p. 28

${ }^{93}$ A notícia do jornal O Estado de São Paulo de 31 de dezembro de 1907 diz que o lugar merecido da tela é o Museu do Estado. Porém, no Correio Paulistano de 04 de agosto de 1909, afirma que o lugar a que se destina a obra é a Pinacoteca do Estado.

94 MENESES, Ulpiano Bezerra de. Museu Paulista. Estudos Avançados, São Paulo, v. 8, n. 22, p. 573578, 1994.p. 573
} 
responsabilidade com a coleção de história era inquestionável, como foi explicitado no seu regulamento ${ }^{95}$ :

Art. 3.․ - Além das coleções de ciências naturais, haverá no Museu uma seção destinada a História Nacional e especialmente dedicada a colecionar e arquivar documentos relativos ao período de nossa independência política.

$\S 1 .^{\circ}$ - Nas galerias e lugares apropriados do edifício serão colocadas as estátuas, bustos ou retratos a óleo de cidadãos brasileiros que, em qualquer ramo ou atividade, tenham prestado incontestáveis serviços a Pátria e mereçam do Estado a consagração de suas obras e feitos e perpetuação de sua memória.

$\S$ 2. - - Para dar cumprimento ao disposto no parágrafo precedente, o governo nomeará uma comissão que se encarregará de indicar dentre os vultos proeminentes de nossa história aqueles cuja memória deverá ser perpetuada.

$\S 3$. - - Desta galeria de homens ilustres não farão parte senão os já falecidos e que tenham a favor o juízo da História.

Art. 4. - - No mesmo museu haverá lugar para o quadro de Pedro Américo, comemorativo da Independência, e para outros de assunto de história e costumes pátrios, adquiridos ou oferecidos ao Estado.

$\S 1$. - Para julgar o valor dos quadros que o Estado resolva adquirir, o governo nomeará uma comissão de profissionais e pessoas entendidas que sobre assunto emitirá parecer ${ }^{96}$

Como se pode observar, o estatuto não deixa dúvidas sobre a sua responsabilidade perante a história e a pintura de assunto histórico. No entanto, como o Museu Paulista foi por mais de dez anos a única instituição museológica de São Paulo, ele abrigou em seu acervo pinturas que nem sempre tinham a preocupação com costumes pátrios e fatos relevantes do passado. Como relatou Barbuy, a festa de inauguração do Museu aconteceu no Salão Nobre do edifício, local em que havia não apenas a pintura monumental Independência ou morte, de Pedro Américo, como também obras de outros pintores brasileiros, como Almeida Junior e Antônio Parreiras. Assim, o Salão Nobre da instituição manteve sua função de galeria artística, mesmo após a inauguração, demonstrando que naquele museu científico também haveria lugar de honra para as artes ${ }^{97}$. Portanto, apesar de não ser um museu especializado, ele abrigou as pinturas consideradas de maior valor artístico e histórico.

\footnotetext{
95 Decreto 249, de 1894, que regulamentou o funcionamento do Museu Paulista. Citado em TAUNAY, Affonso De E. Guia da Secção Histórica do Museu Paulista. São Paulo: Imprensa Official do Estado, 1937.

${ }^{96}$ Decreto 249, de 26 de julho de 1894, grifos meus.

97 BARBUY, Heloisa. O Museu Paulista e a Pinacoteca do Estado. ARAUJO, Marcelo Mattos (org.). Pinacoteca do Estado: a história de um museu. São Paulo: Prêmio; Artemeios, 2007, p. 141.
} 
Essa situação alterou-se com a criação, em 1905, do primeiro museu de arte de São Paulo, cuja implantação partiu da iniciativa de Cardoso de Almeida, então Secretário do Interior e da Justiça, que conseguiu obter uma sala cedida pelo Liceu de Artes e Ofícios. Para acomodar a exposição das obras que, inicialmente, ficaram todas em um mesmo ambiente, o salão do andar superior do prédio sofreu adaptações, como a abertura de uma clarabóia retangular no seu teto. A sua inauguração ocorreu no dia 25 de dezembro de 1905 e contou com a presença da elite paulista ${ }^{98}$. O acervo inicial era composto por 26 quadros $^{99}$ transferidos do Museu Paulista que, como indicou Barbuy,

Examinando-se, hoje, as pinturas que foram para a Pinacoteca e as que permaneceram no Museu Paulista, facilmente se depreende o critério de partilha, baseado nas capciosas noções de "pintura histórica" e "pintura artística", que levaram a manter no Museu Paulista os retratos de personagens considerados históricos e as cenas representativas de grandes acontecimentos, francamente derivados da história factual em vigor naquelas décadas. Mais que isso, de uma história factual paulista. Saía, então, o Caipira picando fumo (Almeida Júnior), antropológico demais para o conceito de história de então, mas ficava, José Bonifácio (Benedito Calixto); ia embora a Cozinha na roça (Pedro Alexandrino), mas deixava-se restar a Fundação de São Vicente (Calixto) ${ }^{100}$.

Como é possível perceber, foi criada uma clivagem entre as instituições, assim, o Museu Paulista poderia cumprir o papel a que fora inicialmente designado - de museu de história natural e história pátria - enquanto à Pinacoteca caberia as pinturas de "valor artístico". Vale destacar que uma das funções da Pinacoteca era formar um gosto estético para as futuras gerações. Além de ser a galeria de arte por excelência da capital, era ainda um local de aprendizado aos futuros artistas, por isso a qualidade estética da obra era um fator essencial, que ficou demonstrado na lei que regulamentou a instituição ${ }^{101}$ :

O dr. Manoel Joaquim de Albuquerque Lins, presidente do Estado de São Paulo. Faço saber que o Congresso Legislativo do Estado decretou e eu promulgo a lei seguinte:

\footnotetext{
98 CAMARGOS, Marcia A Pinacoteca em Oito Tempos: um Ensaio histórico. ARAUJO, Marcelo Mattos (org.). Pinacoteca do Estado: a história de um museu. São Paulo: Prêmio; Artemeios, 2007, p. 39-40.

99 Faziam parte da lista quadros de Almeida Júnior, Oscar Pereira da Silva, Antônio Parreiras, Pedro Alexandrino, BerthaWorms, AntonioFerrigno, Benjamin Parlagreco e Pedro Weingärtner.

100 BARBUY, Heloisa. O Museu Paulista e a Pinacoteca do Estado. ARAUJO, Marcelo Mattos (org.). Pinacoteca do Estado: a história de um museu. São Paulo: Prêmio; Artemeios, 2007, p. 143.

101 Apesar da criação da Pinacoteca do Estado de São Paulo ter ocorrido em1905, sua regulamentação só ocorreu em 1911, com a lei n. 1271, de 21 de novembro.
} 
Artigo 1.․ - A Pinacoteca do Estado é destinada a receber quaisquer obras de arte, de autores nacionais ou estrangeiros, que serão cuidadosamente conservadas para exposição permanente ao publico.

Artigo 2.․ - Os orçamentos anuais do Estado consignarão as necessárias verbas para custeio da Pinacoteca, bem como para aquisição de novos trabalhos, baseada esta exclusivamente no valor artístico dos mesmos ${ }^{102}$.

Como foi apontado no artigo $2^{\circ}$, as verbas para aquisição de obras pautavamse exclusivamente no valor artístico dos mesmos. Isso era muito evidente, pois, quando um quadro era destinado à Pinacoteca, os artigos que noticiavam a aquisição destacavam, sobretudo, suas qualidades artísticas. É preciso que se diga, no entanto, que houve duas exceções dentre as obras transferidas do Museu Paulista para a Pinacoteca, que poderiam questionar esse critério estabelecido entre as instituições. São elas Partida da monção, de Almeida Júnior e o Desembarque de Pedro Álvares Cabral em Porto Seguro em 1500, de Oscar Pereira da Silva.

É possível justificar a transferência da Partida da Monção, pois mesmo ela sendo uma pintura de evidente valor histórico, ela é também um quadro exponencialda obra de Almeida Junior, pintor de grande prestígio, cujas técnicas e concepções formais eram então sobremaneira valorizadas ${ }^{103}$. Era fundamental ao acervo de uma galeria de arte, tal qual se pretendia a Pinacoteca, ter um quadro histórico de Almeida Junior. Essa hipótese explica, em certa medida, também a transferência do Desembarque de Pedro Álvares Cabral em Porto Seguro em 1500, sobretudo, porque a tela havia sido muito bem recebida pela crítica. Outro agravante é o tema nela empregado, já que não representa um evento da Independência política do Brasil e nem coloca os paulistas em papel de destaque na história oficial, assuntos mais caros ao Museu Paulista.

É importante que se diga, no entanto, que o fato da Pinacoteca do Estado ser uma galeria artística não inviabilizava a existência de obras de caráter histórico em seu acervo, contanto que elas tivessem um reconhecido valor estético. Havia, porém, uma grande distinção para a obra, pois estar na Pinacoteca significava ressaltar o aspecto artístico e formal do quadro, isto é, sua qualidade plástica. Ao contrário de pertencer ao Museu Paulista, que evidenciaria o valor histórico e documental da tela.

Como já foi exposto, Oscar Pereira da Silva esforçou-se para fazer um quadro de merecido valor histórico e, para tanto, segundo informa a imprensa, recorreu a

\footnotetext{
102 Lei N. 1.271, de 21 de novembro 1911

103 Para a compreensão do impacto da obra na carreira do artista e para sua fortuna crítica, ver SINGH Júnior.,Oséas. A Partida da Monção: tema histórico em Almeida Júnior. Campinas: Unicamp, 2004. 274 p. Dissertação(Mestrado) - Instituto de Filosofia e Ciências Humanas, Universidade Estadual de Campinas, Campinas, 2004, p. 21- 27.
} 
cronistas e historiadores, a fim de fundamentar o valor documental da obra. Quando ela foi exposta, críticos emitiram seu parecer, afirmando que o artista havia reproduzido um acontecimento histórico, tendo em vista "os testemunhos da época, a importância do fato e a intensidade que o mesmo lhe deve merecer"104. Além disso, havia fixado "elementos colhidos na história da terra paulista"105. Era, portanto, uma pintura indiscutivelmente de assunto histórico, que pretendia se constituir como documento visual da fundação de São Paulo. Logo, o destino óbvio era o Museu Paulista.

A primeira notícia que sugeriu ao governo que adquirisse a obra indicou o Museu Paulista como local adequado ${ }^{106}$. Ademais, na primeira petição enviada à Câmara dos Deputados, Oscar Pereira da Silva demonstrou como seus quadros pretenderam perpetuar assuntos como "origem, costumes, progresso e evolução" do estado. Em seguida, destacou a importância do evento da fundação de São Paulo que seria "o mais importante acontecimento para a terra dos Bandeirantes". Por fim, apelou ao fato do estado de São Paulo não ter uma obra que representasse sua origem.

O Museu Paulista, no entanto, nunca se manifestou a favor da tela, demonstrando completa indiferença. Uma justificativa plausível poderia ser 0 desinteresse de Hermann von Ihering, que haveria deixado a seção histórica da instituição abandonada à própria sorte, sem ter feito aquisições significativas ou sem ter dado tratamento adequado à coleção. Apontamentos como esse foram difundidos, sobretudo, por Afonso de E. Taunay, que assumiu a direção do museu em 1917. Ele dizia que o regulamento da instituição ${ }^{107}$, colocava a Seção de História num plano sobremodo humilde no conjunto dos serviços do museu. Além de afirmar que os poucos quadros históricos existentes, estavam colocados da maneira menos recomendável. E conclui dizendo:

Durante vinte e dois anos, de 1894 a 1916, vegetou a coleção chamada histórica do Museu Paulista, amontoada em duas das menores salas do Palácio do Ipiranga, semi vazio ainda.

Ou antes, praticamente não existiu. Não realizou aquisições senão insignificantes, neste largo lapso de anos. Isto numa época em que as antiguidades de S. Paulo se

\footnotetext{
${ }^{104}$ O Estado de São Paulo, 31 de dezembro de 1907.

${ }^{105}$ Correio Paulistano, 04 de agosto de 1909.

${ }^{106}$ A notícia de 31 de dezembro de 1907, de O Estado de São Paulo, afirma "Aí está um quadro digno de figurar no Museu do Estado".

107 Citado na nota 69.
} 
ofereciam por preços sobremodo inferiores aos que começaram a vigorar nos últimos vinte anos ${ }^{108}$.

Taunay procurou delinear uma visão arrasadora da gestão de von Ihering que é, no entanto, sobremaneira exagerada. Fabio Rodrigo de Moraes desconstrói a suposta inércia da seção histórica e diz que, a despeito da prioridade concedida por von Ihering à história natural, havia no Museu Paulista uma significativa coleção da dita "História Pátria", que foi sendo expandida por ele ${ }^{109}$. Além disso, a prioridade dada às coleções de arqueologia, de zoologia ou de botânica não significava necessariamente que o diretor visse a seção histórica como algo desprestigiado.

Assim, ainda que quantitativamente secundária, a seção de história do Museu Paulista não foi esquecida por Hermann von Ihering. Moraes reconstitui a trajetória de aquisições do Museu Paulista na gestão do primeiro diretor (1896-1916) e demonstra como houve uma significativa ampliação do acervo de História. No que se refere aos quadros, sobretudo os de "interesse histórico" e ligados à história oficial, é a partir de 1900 que houve uma expansão sistemática.

Em virtude do IV Centenário do Descobrimento do Brasil, em 1900, foi recebido o quadro de Benedito Calixto $A$ fundação de São Vicente, oferecido pela comissão responsável pelo evento. $\mathrm{O}$ ano seguinte representou um aumento significativo nas aquisições de quadros. Inicialmente, com a compra ${ }^{110}$ do famoso Partida da Monção, de Almeida Júnior. Em seguida, houve a primeira encomenda realizada pelo museu, feita a Benedito Calixto, que deveria realizar dois retratos: D. Pedro I e Pe. José de Anchieta. A pintura de Oscar Pereira da Silva, Desembarque de Pedro Álvares Cabral em 1500, como já foi dito, foi adquirida em 1902. Mesmo ano em que foram encomendados a Calixto os retratos de Martim Francisco de Andrada e de José Bonifácio. Em 1903, os retratados foram o bandeirante Domingos Jorge Velho e seu loco-tenente Antônio Fernandes de Abreu, bem como Vicente Taques de Góis Aranha,

108 TAUNAY, Affonso d' E. Guia da Secção Histórica do Museu Paulista. São Paulo: Imprensa Official do Estado, 1937, p.47, grifos meus.

\footnotetext{
109 MORAES, Fábio Rodrigo de. Uma coleção de história em um museu de ciências naturais: o Museu Paulista de Hermann von Ihering. Anais do Museu Paulista: História e Cultura Material, São Paulo, vol. 16, no 1.,p. 203-233, jan./jun. 2008.

${ }^{110} \mathrm{~A}$ tela foi comprada pelo governo do estado de São Paulo por trinta mil contos de réis (30:000\$000) e doada ao Museu Paulista. Ver SINGH Júnior.Oséas. A Partida da Monção: tema histórico em Almeida Júnior. Campinas: Unicamp, 2004. 274 p. Dissertação (Mestrado) -, Instituto de Filosofia e Ciências Humanas, Universidade Estadual de Campinas, Campinas, 2004, p. 25-26 e MORAES, Fábio Rodrigo de. Uma coleção de história em um museu de ciências naturais: o Museu Paulista de Hermann von lhering. Anais do Museu Paulista: História e Cultura Material, São Paulo, vol. 16, № 1. jan./jun. 2008, p. 214.
} 
sargento mor de Itu, de autoria do mesmo pintor. Um documento sem datação ${ }^{111}$ indica ainda que tenha ocorrido a encomenda dos quadros de Bartolomeu Gusmão e D. João VI. As telas aqui citadas, sobretudo, as que foram encomendadas, constituemse como indicadores significativos da importância conferida às coleções artísticas e históricas do museu durante a gestão de von Ihering ${ }^{112}$.

É preciso considerar que a criação da Pinacoteca provocou uma brusca diminuição no afluxo de pinturas ao acervo do Museu Paulista, o que, no entanto, não inviabilizou que houvesse novas aquisições para esta instituição. Além disso, não havia tantas ofertas ${ }^{113}$ de telas históricas, sobretudo, de temas tão importantes aos paulistas, para que se justificasse a falta de interesse das autoridades pela aquisição da obra, principalmente se considerarmos que a transferência de 1905 havia desfalcado o acervo de pintura histórica do Museu Paulista. A hipótese sugerida aqui para esclarecer esse impasse apela para os aspectos formais e compositivos da obra, bem como o impacto destes na historiografia paulista.

Como já foi exposto, desde o final do século XIX, procurou-se traçar, nos meios intelectuais e artísticos do estado, uma identidade característica a São Paulo, processo pelo qual se procurou transformar os paulistas sertanejos nos míticos bandeirantes, por meio do enaltecimento do papel dos patriarcas das famílias mais proeminentes dos tempos das bandeiras e seus descendentes na cafeicultura. Além disso, como demonstrou John Monteiro $^{114}$, as primeiras décadas da República ocasionaram um amplo debate sobre os índios. O Instituto Histórico e Geográfico de São Paulo, o Museu Paulista e a Comissão Geográfica e Geológica pretendiam realçar o papel do índio, robusto e valente precursor do povo paulista. Assim, reafirmavam o mito de origem de São Paulo, que esteve abalado pelas polêmicas engendradas por historiadores que questionavam a filiação étnica e lingüística ${ }^{115}$ dos habitantes nativos do planalto de Piratininga. O resgate das origens tupi de São Paulo, no entanto, estavam envoltas por uma outra polêmica do período: o extermínio dos índios

\footnotetext{
111 Informação retirada de MORAES, Fábio Rodrigo de. Uma coleção de história em um museu de ciências naturais: o Museu Paulista de Hermann von Ihering. Anais do Museu Paulista: História e Cultura Material, São Paulo, vol. 16, no 1.jan./jun. 2008, p. 11.

112 MORAES, Fabio Rodrigo de. Uma coleção de história em um museu de ciências naturais: o Museu Paulista de Hermann von Ihering. Anais do Museu Paulista: História e Cultura Material,São Paulo, v. 16, p. 203-233, 2008, p. 7-12.

${ }^{113}$ A elaboração de um quadro histórico despendia muito dinheiro e tempo do artista. No período de 1906 a 1913 a única oferta em São Paulo de pintura histórica divulgada nos jornais O Estado de São Paulo e Correio Paulistano era a de Oscar Pereira da Silva.

114 MONTEIRO, John M. Tupis, Tapuias e a História de São Paulo. Revisitando a velha questãoguaianá. Novos Estudos. CEBRAP, São Paulo, v. 34, p. 125-135, 1992.

${ }^{115}$ A questão, fundamentalmente, residia na polêmica entre ascendência tupi ou tapuia dos nativos do planalto paulista.
} 
Kaingang ocasionado pela expansão para o oeste ${ }^{116}$. Diante dessas tensões, a incorporação dos índios no pensamento histórico paulista era considerado imprescindível.

Portanto, paralelamente ao enaltecimento geográfico do estado que acolhera as primeiras vilas brasileiras na costa e no sertão, São Vicente e São Paulo, surgiram as propostas de evidenciar o papel desempenhado pelas elites locais e regionais nos destinos paulistas e do próprio país. Diante disso, é evidente que o ideal de imagem do marco inaugural de São Paulo deveria, sobretudo, ressaltar a síntese entre gentio e colonizador, elementos fundamentalmente constituintes da "raça paulista".

Oscar Pereira da Silva havia, forçosamente, tentado demonstrar, na petição enviada ao Congresso do Estado em 1908, que os indígenas progenitores não haviam sido esquecidos na representação, acrescentou ainda, que Caiuby e Tibiriçá encontravam-se em "imponente e solene atitude no mesmo lugar em que tem sede hoje o honrado governo do Estado" ${ }^{117}$. Quando se observa a tela, no entanto, não é isso que se vê, já que o quadro está centrado na missão religiosa e a ação protagonista está concentrada nos jesuítas. Assim, tanto gentio quanto colonizador exercem papel periférico, seja na posição em que ocupam no quadro, seja na função que desempenham no ato de fundação. Os índios Tibiriçá e Caiuby, não estão em evidência, ao contrário, misturam-se ao demais. Além disso, é possível notar uma submissão explícita na posição da maior parte dos corpos dos indígenas, que se curvam à medida que se aproximam da cruz.

O tema da fundação era, indubitavelmente, considerado relevante, por isso, em 1913, o prefeito da cidade, Raymundo Duprat, requisitou uma tela do mesmo assunto a Antônio Parreiras (imagem3). Como é possível explicar uma encomenda se, apenas alguns anos antes, Oscar Pereira da Silva ofertava insistentemente sua obra às autoridades? A valorização da "pose imponente" do índio, já indicada por esse pintor $^{118}$, soluciona a questão. Se o incômodo da tela de 1907 residia no papel atribuído aos progenitores, a nova versão de Parreiras lhe conferiu o desejado destaque:

\footnotetext{
${ }^{116}$ MONTEIRO, John M. Tupis, Tapuias e a História de São Paulo. Revisitando a velha questão guaianá. Novos Estudos. CEBRAP, São Paulo, v. 34, p. 125-135, 1992.

${ }^{117}$ O Estado de São Paulo, 18 de julho de 1908.

${ }^{118}$ Refere-se à petição enviada por Oscar Pereira da Silva em 1908, que diz que Caiuby e Tibiriçá estariam em "pose imponente".
} 
Representa esse quadro a missa campal realizada a 25 de Janeiro de 1554, na colina onde hoje se ergue o palácio do governo paulista.

No primeiro plano, à direita, entre grandes árvores, vê-se o altar. Celebra o padre superior Manuel de Paiva, servindo de acolito Anchieta. Rodeando o altar vêm-se os outros doze padres que foram aos campos de Piratininga, fundar S. Paulo Um pouco afastado, mais próximo do observador, vê-se um grupo formado pelo desterrado Ramalho e pelo índio Caiuby. É este grupo isolado que equilibra toda a composição ${ }^{119}$.

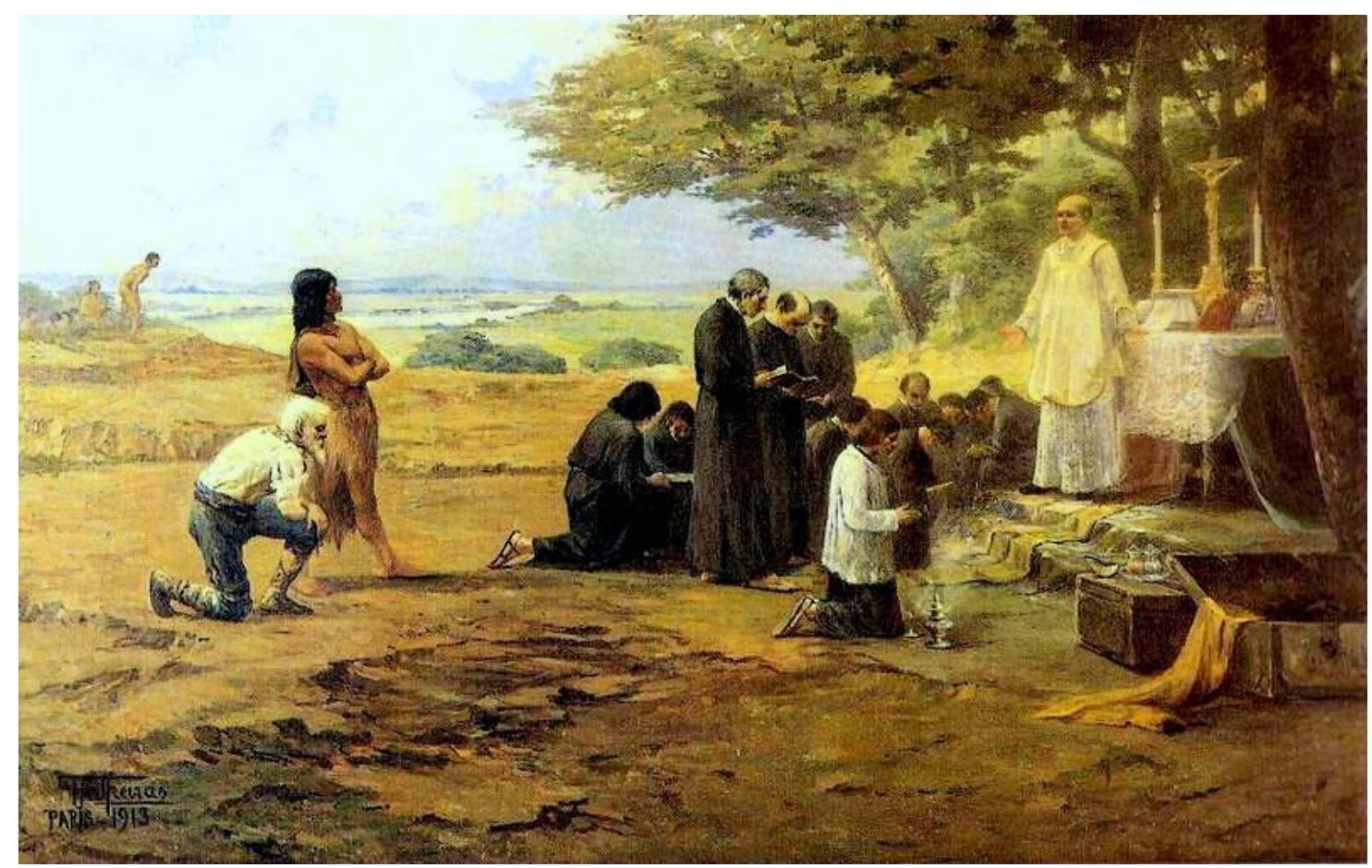

Imagem 3 - Antonio Parreiras, Fundação de São Paulo, 1913. Óleo sobre tela, $200 \times 300 \mathrm{~cm}$. Prefeitura de São Paulo. Retirado de http://laboratorioart.blogspot.com.br/2012/03/visita-ao-pateo-do-collegio-saopaulo.html Acesso em 20/11/2012

Como bem demonstrou o articulista $^{120}$, na composição de Parreiras, não há uma hierarquia entre religiosos e índios imposta pela posição que ocupam no quadro. Ao contrário, aqueles que estão próximos ao observador, são justamente os representantes da parentela paulista. A presença do gentio não é marcada pela mera aceitação e submissão, mas como protagonista dessa história. Ele e o europeu encontram-se lado a lado, o que indica uma simbiose de valores e não uma imposição.

Além disso, o envolvimento de von Ihering nas polêmicas em torno do extermínio indígena constituiu mais um empecilho para que a tela de Oscar Pereira da Silva adentrasse ao Museu Paulista. Diante de tais acusações, adquirir uma tela em

\footnotetext{
${ }^{119}$ O Estado de São Paulo, 09 de outubro de 1913.

${ }^{120} \mathrm{~A}$ notícia foi publicada na coluna Artes e Artistas do jornal O Estado de São Paulo, porém não está assinada.
} 
que os índios constituem elemento formador do povo que ali está se estabelecendo e que, além de tudo, entendem harmoniosamente a cultura que lhes é imposta, certamente não seria tarefa fácil. Diante de tudo isso, o próprio artista percebe que para vender sua obra seria necessário apelar para o valor artístico e apostar na Pinacoteca do Estado.

Assim, a justificativa que ele utilizou na segunda petição que enviou à Câmara, em 1909, foi completamente distinta da primeira. Desta vez, ele não se refere ao valor histórico nem à importância do tema. "Limita-se, por isso, a juntar os dizeres unânimes da imprensa, além do parecer autorizado do grande pintor francês, Mr. Gabriel Biessy" ${ }^{21}$. Como dito, recorreu a um artista conhecido que pudesse aferir e comprovar o valor artístico da obra. Por fim, disse que os membros do Congresso poderiam julgar, com os seus conhecimentos e com as "opiniões insuspeitas" que eram anexadas ao processo, o merecimento do quadro "determinando a aquisição dele para a Pinacoteca do Estado, que é o que espera o suplicante da sabedoria e Justiça dos representantes do povo na assembleia legislativa". Essa colocação comprova que o próprio artista sugestionou que o local mais adequado seria a Pinacoteca. E foi para lá que a obra foi encaminhada no início de 1910.

A despeito de todos os percalços que envolveram a aquisição da tela, o artista conseguiu atingir seu objetivo. A venda do quadro ao Estado não se justificava apenas pela retribuição pecuniária, já que telas de menor tamanho eram claramente mais fáceis de serem vendidas. A pretensão do pintor era, sobretudo, obter prestígio e projeção, que só uma obra de grande formato, exposta em uma instituição pública, poderia the garantir. A sua consagração como pintor em São Paulo pode ser notada pelo aumento significativo de encomendas de obras de grande formato feitas a Oscar Pereira da Silva, como os três painéis representando as artes que realizou para o Teatro Municipal de São Paulo, em 1911. Dois anos depois fez obras para a Igreja de Santa Cecília. Em 1916, pintou os quadros A colheita e o beneficiamento de algodão e O desembarque do café no Porto de Santos, para a Escola Superior de Agronomia Luiz de Queiroz, em Piracicaba. Realizou também vários retratos, como o de José Bonifácio, D. Pedro I, Joaquim Gonçalves Lêdo, Padre Antonio Diogo de Feijó, em 1922, para o Museu Paulista. Além disso, foi requisitado para fazer cópias de quadros de artistas estrangeiros, como em 1913, de Ribera, Velásquez, Rubens e Rembrandt, a pedido do governo do estado de São Paulo; e no ano seguinte, Prudhon e Ribera,

\footnotetext{
${ }^{121}$ Documento enviado aos membros do Congresso Legislativo do Estado de São Paulo, que descreve a petição enviada por Oscar Pereira da Silva e é assinado por "E.RM.". O documento foi encontrado no Arquivo do Estado de São Paulo (APESP), intitulado Secretaria da Câmara dos Deputados, 1ำ Seção, 1a Subdiretoria - Secretaria do Interior.
} 
encomendados por Altino Arantes, secretário do Interior, para a Pinacoteca. Além disso, em 1925 viajou a Paris como pensionista do estado de São Paulo.

A entrada da Fundação de São Paulo na Pinacoteca do Estado não silenciou a imprensa, que continuou a emitir considerações a respeito da tela, em que os atributos estéticos foram sempre destacados, como foi evidenciado na revista llustração Brasileira, que reproduziu o quadro (imagem 4) e o descreveu:

Mais uma série de obras perfeitas encontrarão os nossos leitores, reproduzidas em trichromias, no presente número. São quadros de grande valor artístico, como é fácil verificar: A Pompeiana, de Zeferino da Costa - o mestre dos mestres -: Dois Irmãos, de João Baptista da Costa: Fundação de São Paulo, por Oscar Pereira da Silva, e Minha terra, de Hélios Scelinger.

[...] De Oscar Pereira da Silva é a Fundação de São Paulo, pertencente à Pinacoteca do Estado. É uma movimentada tela, cheia de sol e detalhes preciosos. O artista empregou o seu talento numa das composições mais ingratas, e saiu-se maravilhosamente. O grupamento das figuras é de tal forma feito que agrada ao primeiro exame; as atitudes são sentidas e os movimentos compreendidos. As expressões revelam um conhecimento perfeito da psicologia e psicologia das paixões: o medo, a altivez, a indecisão, a desconfiança, o desprezo, a humildade, estão concretizados dentro dos silvícolas do quadro; tais sentimentos refletem-se nos gestos e na expressão do olhar.

A cena do fundo é encantadora dentro da paisagem .

Oscar Pereira da Silva foi discípulo de J.Medeiros, Zeferino da Costa, Victor Meirelles de Lima e Chaves Pinheiro.

Matriculou-se na antiga Academia de Belas Artes em 1862 e terminou o seu curso em 1887, quando tirou o premio de viagem à Europa, onde estudou com Jerome e Bounat ${ }^{122}$.

122 Ilustração Brasileira, janeiro de 1923, grifos meus 


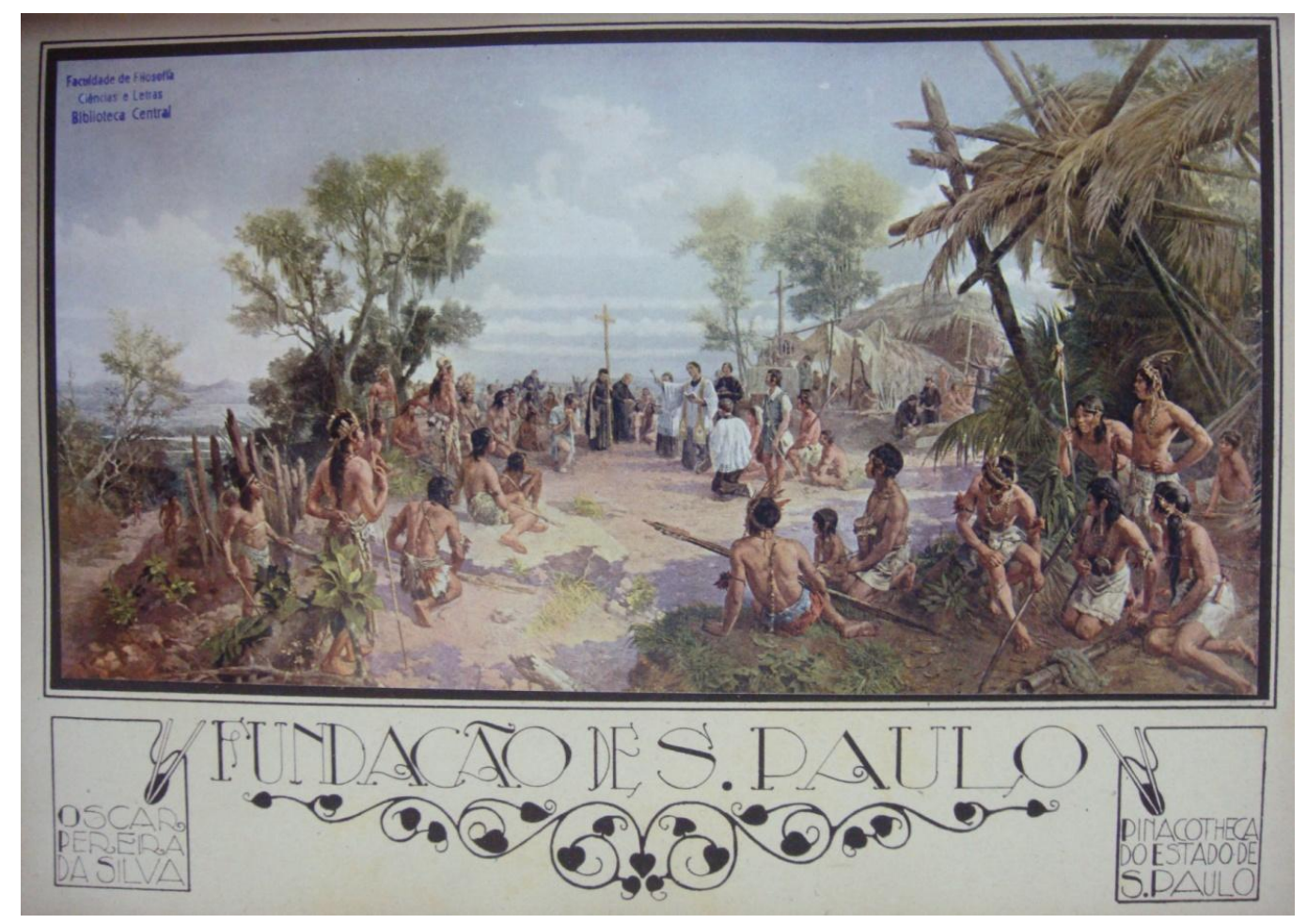

Figura 4 - Revista llustração Brasileira, janeiro de 1923

O excerto evidenciou a rigorosa técnica empregada e os inúmeros escorços que o artista utilizou, demonstrando sua qualidade como pintor. Fez questão de nomear os mestres de Oscar Pereira da Silva, pois isso era uma maneira de enaltecer o seu trabalho. Ousou até dizer que a obra é perfeita, porém, não mencionou seu valor documental ou histórico. Esse quadro ficou exposto em uma sala do Liceu de Artes e Ofícios, que foi o local que agregou todo o acervo da Pinacoteca, até 1928. Lá cumpriu a sua possibilidade de apropriação estética, até 1929, quando foi transferido para o Museu Paulista.

Senhor Conservador da Pinacoteca do Estado.

Solicito-vos providencias no sentido de serem entregues ao Liceu de Artes e Ofícios, para serem transportados ao Museu Paulista, os seguintes quadros:

Partida da Monção, de Almeida Junior;

Fundação de São Paulo e Descoberta do Brasil, de Oscar Pereira da Silva.

Atenciosas saudações,

(Ofício 159 da Secretaria do Estado do Interior de 03 de abril de 1929, Pinacoteca do Estado de São Paulo) 


\title{
CAPÍTULO 3
}

\section{Uma janela para vários passados: do museu para a cidade}

\begin{abstract}
"Havendo o Snr. Dr. Fabio de Sá Barreto, Secretario do Interior, decidido transferir da Pinacoteca do Estado para o Museu do Ipiranga o grande painel de Almeida Junior "A Partida da Monção", tendo em vista que a frequência do Museu Paulista é, quiçá, doze vezes mais avultada do que a da Pinacoteca, determinou tal transferência a inauguração de uma nova sala do Palácio do Ipiranga, consagrada às monções e a Almeida Junior"'.
\end{abstract}

Em abril de 1929, o Secretário dos Negócios do Interior, Fábio de Sá Barreto, enviou um ofício ${ }^{2}$ à Pinacoteca do Estado pedindo a transferência de três obras: Partida da Monção, de Almeida Júnior, Desembarque de Pedro Álvares Cabral em Porto Seguro em 1500 e a Fundação de São Paulo, ambos de Oscar Pereira da Silva. As telas foram encaminhadas ao Museu Paulista e, contudo, como foi indicado no Relatório Anual da instituição, citado acima, houve um completo silêncio em torno das obras de Oscar Pereira da Silva, que nem sequer foram mencionadas nesse documento. Para compreender as condições em que se deu essa transferência e como ela foi fundamental para a trajetória da obra aqui em questão - apesar da obliteração já mencionada - é importante reconstituir o contexto em que se situavam as duas instituições, o que haveria motivado a transferência das três telas e, sobretudo, o impacto dessa outra visibilidade para a Fundação de São Paulo, que, em seu novo ambiente, foi reapropriada e ressignificada não apenas como obra de arte, mas como documento privilegiado sobre o passado da cidade de São Paulo. Assim num arco de um quarto de século, a tela passaria de janela "inconveniente" a uma certa interpretação do passado para imagem que metaforizava o destino da cidade, coesa, em direção ao futuro.

\section{Telas para um monumento}

Hermann von Ihering esteve à frente da direção do Museu Paulista desde a sua fundação, em 1894, até agosto de 1916, quando foi afastado do cargo, em decorrência de desentendimentos em relação à prestação de contas com a Secretaria da

\footnotetext{
${ }^{1}$ Relatório Anual Museu Paulista 1929, p. 14

${ }^{2}$ Ofício 159 da Secretaria do Estado do Interior de 03 de abril de 1929, citado na íntegra no capítulo anterior.
} 
Agricultura e com a Secretaria do Interior. Foi, então, aberta uma sindicância e feito um inventário para apurar problemas administrativos e desvios de objetos de acervo. A Comissão Inspetora constatou inúmeras irregularidades, por isso, em 1916, Armando Prado assumiu o cargo de diretor interino até 1917, quando Affonso Taunay foi nomeado diretor da instituição. Substituiu-se, assim, o zoólogo ${ }^{3}$ pelo historiador ${ }^{4}$, troca que, certamente, não foi ocasional.

Como demonstrou Ana Claudia Brefe, o próprio decreto ${ }^{5}$ que regulamentou o funcionamento do museu nas suas primeiras décadas, estabelecia que a sua finalidade era estudar a História Natural. Assim, ele se tornou, nesse período, um centro de instrução pública e de pesquisa no campo das ciências naturais, que atraiu estudiosos estrangeiros e brasileiros. Em contrapartida, a seção histórica existia mas não estava colocada em primeiro plano ${ }^{6}$. O edifício funcionava secundariamente como um memorial em homenagem a acontecimentos e homens que não deveriam ser esquecidos ${ }^{7}$.

É possível dizer que a alteração da direção do museu revelava a intenção do governo estadual de São Paulo em atribuir um novo perfil à instituição, destacando seu caráter histórico, sobretudo, em função dos preparativos para as comemorações do centenário da Independência, que ocorreria em 1922. A celebração dessa data mobilizou numerosos segmentos da população brasileira, sobretudo, de intelectuais e políticos que estavam comprometidos com a afirmação de uma identidade coletiva, ou seja, uma base para a construção da nação. Dessa maneira, foram muitos os esforços empreendidos por certos setores das elites dirigentes, especialmente

\footnotetext{
${ }^{3}$ Hermann von Ihering era formado em zoologia, e dedicava grande parte de seus estudos à etnologia. Durante os anos que esteve à frente do Museu Paulista, atribuiu-Ihe um caráter essencialmente de Museu de História Natural.

${ }^{4}$ Affonso de Escragnolle Taunay era engenheiro de formação e professor da Escola Politécnica de São Paulo. Optou, porém, por seguir a carreira de historiador, cujo marco inicial haveria sido em 1910, com a publicação de Crônicas do Tempo dos Felipes. No ano seguinte, tornou-se membro do Instituto Histórico e Geográfico Brasileiro (IHGB) e também do Instituto Histórico e Geográfico de São Paulo (IHGSP). Ele se destacou com as pesquisas e produções na área de história, tendo como principal objeto de estudo o estado de São Paulo, sobretudo, o movimento bandeirista, a história da cafeicultura e da cidade de São Paulo.

${ }^{5}$ Decreto n. 249 de 26 de julho de 1894cf.: BREFE, Ana Claudia Fonseca. Museu Paulista, Affonso de Taunay e a memória nacional (1917 - 1945). São Paulo: Editora Unesp: Museu Paulista, 2005.

${ }^{6}$ Segundo Claudia Valladão de Mattos, durante a gestão von Ihering, o "Palácio Bezzi" não deixara de ser monumento à Independência, aspecto ressaltado por sua arquitetura imponente e pela presença do famoso quadro de Pedro Américo "Independência ou Morte!", que se encontrava desde 1895 no salão de honra do Museu. Contudo, funcionava como museu de ciências naturais, função esta que não se refletia no caráter do prédio. O museu de von Ihering utilizava apenas o espaço físico do edifício, sem qualquer atenção a seu caráter simbólico. MATTOS, Cláudia Valladão de. "Da palavra à imagem: sobre o programa decorativo de Affonso Taunay para o Museu Paulista". Anais do Museu Paulista: História e Cultura Material, São Paulo, n. 6/7 (1998/1999), 2003, p 124.

${ }^{7}$ BREFE, Ana Claudia Fonseca. Museu Paulista, Affonso de Taunay e a memória nacional (1917 - 1945). São Paulo: Editora Unesp: Museu Paulista, 2005, p. 93.
} 
cariocas e paulistas, a fim de estabelecer uma memória coletiva, que encontrasse respaldo na população ${ }^{8}$. Para atingir esse objetivo, tornou-se imprescindível dotar de tangibilidade a memória que estava sendo forjada, por meio da criação de museus, esculturas e monumentos, ou seja, "lugares" em que a memória pudesse se cristalizar, a exemplo do que se processara na França durante o século $\mathrm{XIX}^{9}$.

O fato do Museu Paulista estar situado na colina do Ipiranga era muito significativo, já que havia sido lá que o afamado "brado da Independência" fora propalado em 1822. Portanto, era grande o interesse do governo paulista em fixar o museu e seu entorno como "lugar de memória" nacional, ou seja, lócus de origem da nação brasileira. Essa fora a principal razão que levara à construção do edifício monumento ainda sob o Império e, já no século $X X$, alimentava a motivação para novos reforços simbólicos. Foi nesse sentido que a Secretaria do Interior do estado de São Paulo organizou, em 1919, um concurso para edificação de um monumento escultórico em homenagem à emancipação brasileira, que contou com a participação de artistas nacionais e estrangeiros e obteve grande repercussão na imprensa. $O$ resultado foi e ereção de um monumento em granito e bronze, feito pelo artista italiano Ettore Ximenez. Havia também uma proposta para reformulação dos jardins da praça da independência que, juntamente, com o Museu e o monumento que seria construído, comporiam um eixo monumental que daria acesso ao conjunto a partir da avenida do Estado e do centro da cidade. Diante dessas pretensões que, em 1917 não passavam de planos, era imprescindível que o Museu Paulista fosse reformulado, de modo a inseri-lo enfaticamente na órbita das comemorações da independência brasileira, matizando seu caráter de museu de ciências naturais. Por isso, tornou-se providencial a presença de um historiador à frente da instituição.

Taunay utilizou-se de seus estudos historiográficos e de seu conhecimento dos métodos e conceitos da história atribuindo à instituição os principais contornos de um museu histórico, adequando-a, assim, ao lugar em que o edifício havia sido construído e à própria justificativa de ereção de um monumento arquitetônico voltado a ser um memorial à Independência. Ele não poupou críticas à gestão de von Ihering, apontando para a má conservação dos móveis das salas de exposição e dos materiais

\footnotetext{
${ }^{8}$ Era fundamental criar o que Baczko chamou de "comunidade de imaginação" e Benedict Anderson de "comunidades imaginadas", já que a eficácia política da criação de um símbolo ou de um conceito nacionalidade dependia desse terreno comum, ou seja, a comunhão com a população. Ver em BACZKO, Bronislaw. Imaginação social. In: ROMANO, Ruggiero (org) Enciclopédia Einaudi. Lisboa: Imprensa Nacional/Casa da Moeda, 1985, v.5 e ANDERSON, Benedict. Comunidades imaginadas. São Paulo: Companhia das Letras, 2007.

${ }^{9}$ NORA, Pierre. Entre Memória e História: a problemática dos lugares. Revista Projeto História, São Paulo, no 10, 1993, p.7.
} 
nelas expostos, assim como o desfalque nas obras da biblioteca e, sobretudo, o "abandono" das coleções de história originais do museu. Chocava a Taunay o aspecto das salas, cuja disposição ${ }^{10}$ dos "objetos históricos" revelava uma completa falta de critérios estéticos e científicos ${ }^{11}$.

Dessa maneira, o novo diretor reorganizou por completo a instituição. Para tanto, desenvolveu amplamente a seção histórica, dinamizando-a, a fim de que tornasse, efetivamente, referência de pesquisa e instrução pública. Procurou reunir documentos inéditos para a pesquisa da história de São Paulo e do Brasil, pois esses se compunham como testemunho do passado e matéria-prima indispensável para reconstruir o que haveria acontecido. Além disso, empenhou-se na aquisição de retratos de grandes vultos da história do Brasil e, pouco a pouco, começou a obter os elementos fundamentais para a composição iconográfica do museu, que se constituiu como um dos pilares para a composição da Seção de História.

Nesta nova configuração, cada objeto, quadro ou documento tinha uma função muito específica capaz de comprovar e demonstrar item a item, fato a fato, a história que ali estava sendo forjada. Ainda em 1917, Taunay inaugurou duas novas salas do museu - A7 e A10. Contudo, foi a partir de 1919 que ele passou a se dedicar com maior afinco na pesquisa para a elaboração do projeto de ornamentação do museu para os festejos de 1922, a pedido da Secretaria do Interior ${ }^{12}$. Nesse mesmo ano, ele contratou alguns artistas que seriam encarregados da execução das telas históricas, dos retratos dos vultos da Independência e das estátuas que iriam compor a decoração histórica do museu ${ }^{13}$. Oscar Pereira da Silva, como foi indicado no capítulo 2, foi muito requisitado para esses trabalhos, sobretudo, para a elaboração dos

\footnotetext{
${ }^{10}$ Segundo Brefe, "a má impressão que essas salas pareciam causar no visitante, segundo conta Taunay, devia-se, sem dúvida, ao contraste existente entre as coleções de história natural, rigorosamente classificadas e expostas segundo critérios vigentes na disciplina científica, e as coleções de história, que mais pareciam um depósito de coisas antigas e disparatadas, um velho gabinete de curiosidade, bem ao gosto dos colecionadores dos séculos anteriores. Os objetos pareciam aleatoriamente expostos, sem nenhum tipo de classificação temática, tipológica, cronológica, ou outra que fosse". BREFE, Ana Claudia Fonseca. Museu Paulista, Affonso de Taunay e a memória nacional (1917 - 1945). São Paulo: Editora Unesp: Museu Paulista, 2005, p. 92.

11 BREFE ,Ana Claudia Fonseca. Museu Paulista, Affonso de Taunay e a memória nacional (1917 1945). São Paulo: Editora Unesp: Museu Paulista, 2005, p.90.

12 Segundo Brefe, no ano de 1919, a Secretaria do Interior do estado de São Paulo solicitou a Taunay um plano detalhado sobre o que poderia ser feito para o preparo do Monumentos do Ipiranga para as festas centenárias de 1922. Então, Taunay enviou ao secretário, Oscar Rodrigues Alves, uma carta com algumas de suas idéias iniciais. BREFE, Ana Claudia Fonseca. Museu Paulista, Affonso de Taunay e a memória nacional (1917 - 1945). São Paulo: Editora Unesp: Museu Paulista, 2005, p.114.

${ }^{13}$ Segundo Brefe, "entre aqueles que forma contratados, além dos nomes de destaque de São Paulo, como Oscar Pereira da Silva, Domenico Failutti, Benedito Calixto, Wasth Rodrigues, Taunay fez questão de convidar renomados pintores e escultores da Escola Nacional de Belas-Artes para realizarem importantes trabalhos para o museu, como Fernandes Machado, Rodolfo Amoedo e os irmãos Henrique e Rodolfo Bernardelli". BREFE, Ana Claudia Fonseca. Museu Paulista, Affonso de Taunay e a memória nacional (1917 - 1945). São Paulo: Editora Unesp: Museu Paulista, 2005, p. 121.
} 
retratos e de cenas históricas que comporiam o Salão de Honra, principal ambiente do Museu Paulista por abrigar a tela "Independência ou Morte". Nas palavras do próprio Taunay:

No Salão de Honra fiz colocar os quatro dos cinco grandes medalhões decorativos que devem acompanhar o notável quadro de Pedro Américo. Assim fiz executar os retratos a óleo de D. Pedro I, José Bonifácio, José Clemente Pereira e Diogo Antonio Feijó pelo nosso acreditado pintor, Sr. Oscar Pereira da Silva, que com sua habitual proficiência artística executou quatro excelentes telas ${ }^{14}$.

Além desses retratos, Oscar Pereira da Silva também seria responsável pela elaboração de dois grandes painéis a óleo que representavam momentos decisivos do processo de Independência - A tela O Príncipe $D$. Pedro e Jorge de Avilez a bordo da Fragata União e Sessão da Cortes de Lisboa - posicionadas exatamente em frente à tela de Pedro Américo. Isso demonstra que Oscar Pereira da Silva havia conseguido conquistar espaço de prestígio no meio artístico paulista ${ }^{15}$, sobretudo porque, como afirmou, Ana Claudia Brefe, a composição iconográfica do salão de honra foi a prioridade no projeto de decoração do Museu Paulista para as festas centenárias ${ }^{16}$.

Segundo Makino ${ }^{17}$, no final de 1919, Taunay apresentou os primeiros estudos e realizou contatos para a contratação de serviços e, em 1920, o projeto em si estava pronto. Taunay disse que havia consultado a opinião de artistas que considerava de reconhecido valor para a elaboração do projeto. Dentre eles, estava Oscar Pereira da Silva, como foi dito por Taunay:

o projeto da sanca é todo do Prof. Amoedo. O da escadaria tem a aprovação plena do prof. Rodolpho Bernardelli. Conversei longamente com artistas do valor dos srs. Prof.

\footnotetext{
${ }^{14}$ Relatório Anual do Museu Paulista, 1920

${ }^{15}$ Segundo Cláudia Valladão Mattos, a decoração do salão nobre deveria ser executada por professores da Escola Nacional de Belas Artes, contudo, o projeto teve de ser reestruturado, diante das dificuldades surgidas durante sua implementação efetiva. Ao mesmo tempo, havia um grande esforço dos artistas paulistas para receber encomendas importantes do Museu Paulista. Assim, depois de já terem recebido a encomenda para a pintura dos retratos da sanca, Oscar Pereira da Silva e Domenico Failutti apresentaram uma proposta para Taunay que incluía vários painéis para o salão nobre. Assim, por questões de preço e controle sobre a execução dos trabalhos, Taunay entregou a decoração do salão nobre também a Failutti e Oscar Pereira da Silva. Ver MATTOS, Cláudia Valladão de. "Da palavra à imagem: sobre o programa decorativo de Affonso Taunay para o Museu Paulista". Anais do Museu Paulista: História e Cultura Material, São Paulo, n. 6/7 (1998/1999), 2003, p 134.

${ }^{16}$ BREFE, Ana Claudia Fonseca. Museu Paulista, Affonso de Taunay e a memória nacional (1917 1945). São Paulo: Editora Unesp: Museu Paulista, 2005, p.124.

17 MAKINO, Miyoko. "Ornamentação do Museu Paulista para o Primeiro Centenário: construção de identidade nacional na década de 1920". Anais do Museu Paulista: História e Cultura Material, São Paulo, n.10/11, pp. 167-195, 2002/2003.
} 
Brizzolara, Cr. Ximenes, Fernandes Machado, Oscar Pereira da Silva, D. Adalberto Gresnigt, entre outros ${ }^{18}$.

É importante observar que a construção de uma narrativa visual foi o grande suporte de Taunay na composição histórica do museu. Como indicou Brefe, foram as imagens e a forma pela qual elas foram dispostas que reconstruíram o espaço e dotaram de sentido. Ainda em 1920, foram contratados os serviços do modelador holandês Henrique Bakkenist para fazer a maquete da São Paulo de 1840, com a dimensão de $5,1 \times 6 \mathrm{~m}$, que serviria para evocação da própria cidade, já completamente transformada por conta da riqueza do café.

No final de 1920, Affonso Taunay conseguiu, em razão das obras de abertura da Avenida da Independência, fechar o museu por tempo indeterminado. Dessa maneira, poderia preparar o edifício para as festas centenárias com maior tranquilidade e longe dos olhos do público. Brefe afirma que essa medida haveria contribuído para criar um "tom de mistério" e expectativas em relação àquilo que estava sendo realizado ${ }^{19}$. A reabertura do museu com a nova decoração interna só ocorreu no dia 7 de setembro de 1922. Porém, nem tudo havia sido concluído, como era o esperado por Taunay:

No ano de 1922, todos os esforços de Taunay concentraram-se em tentar finalizar as obras começadas no museu. Ele instalou, então, todos os objetos históricos que vinha colecionando desde 1917 em seus devidos lugares, bem como organizou as exposições iconográficas e escultural representando, num conjunto harmoniosamente disposto, a história da nação brasileira de um novo ponto de vista. Entretanto, apesar de ter transformado por completo o cenário interno do museu, Taunay não conseguiu realizar tudo aquilo que havia idealizado para as festas centenárias ${ }^{20}$.

Como bem indicou Cláudia Valladão de Mattos, entre 1922 e 1937, Taunay acrescentou uma série de elementos à decoração do corpo do edifício, que reorientaram em grande medida o trabalho anterior. A composição das salas procurou demonstrar a importância do passado de São Paulo para a História do Brasil sob o viés de seu momento fundador: o bandeirantismo. Dessa maneira, o então estado de São Paulo se comportaria, em seu remoto passado de capitania, como centro gerador e difusor da nacionalidade, unificando, assim, toda a decoração do edifício sob a égide

\footnotetext{
${ }^{18}$ Relatório Anual do Museu Paulista, 1921.

19 BREFE, Ana Claudia Fonseca. Museu Paulista, Affonso de Taunay e a memória nacional (1917 1945). São Paulo: Editora Unesp: Museu Paulista, 2005, p.126.

20 BREFE, Ana Claudia Fonseca. Museu Paulista, Affonso de Taunay e a memória nacional (1917 1945). São Paulo: Editora Unesp; Museu Paulista, 2005, P. 135.
} 
de uma concepção evolutiva de história ${ }^{21}$. Foi nesse contexto de organização das salas dedicadas à história paulista que a tela Fundação de São Paulo, foi transferida da Pinacoteca do Estado para o museu, em 1929, acompanhada de Desembarque de Pedro Álvares Cabral em Porto Seguro em 1500 e a Partida da Monção.

Tais transferências, como veremos, trariam nova evidência às telas de Oscar Pereira da Silva, mas inseriam-se de maneira difícil numa narrativa em que tanto o desembarque em Porto Seguro quanto o protagonismo dos jesuítas na fundação de São Paulo não tinham ampla ressonância na interpretação histórica de Taunay.

\section{Uma transferência indesejada?}

Eram estreitos os laços entre Museu Paulista e Pinacoteca do Estado, já que essa havia composto seu acervo inicial com a transferência, em 1905, de obras daquela instituição, assunto abordado no capítulo 2 desta dissertação. Como relatou Heloisa Barbuy ${ }^{22}$, houve, em diferentes momentos, uma sucessão de idas e retornos de obras entre as duas instituições ${ }^{23}$. A transferência de 1929, portanto, não representou um episódio excepcional.

É importante, no entanto, apontar alguns aspectos sobre o acervo da Pinacoteca, bem como demonstrar como a instituição era vista pela sociedade paulista. Desde a sua regulamentação, em 1911, ela havia ganhado autonomia financeira para encaminhar solicitações orçamentárias à Secretaria do Estado, sem intermediários. Além disso, beneficiava-se indiretamente do pensionato artístico, dirigido por Freitas Valle ${ }^{24}$, que concedia bolsas de aperfeiçoamento na Europa a

\footnotetext{
${ }^{21}$ MATTOS, Cláudia Valladão de. "Da palavra à imagem: sobre o programa decorativo de Affonso Taunay para o Museu Paulista". Anais do Museu Paulista: História e Cultura Material, São Paulo, n. 6/7 (1998/1999), 2003, p. 142-143.

22 BARBUY, Heloisa. O Museu Paulista e a Pinacoteca do Estado. In: ARAUJO, Marcelo Mattos; CAMARGOS, Marcia. (Org.). Pinacoteca do Estado: a história de um museu/The History of the Museum. São Paulo: Artemeios, 2008, p. 137-145.

${ }^{23}$ Essas trocas não cessaram na gestão de Taunay. Como descreveu Barbuy, quando Sérgio Buarque de Holanda assumiu a direção do Museu Paulista, houve a transferência de dezenove obras de Almeida Júnior para a Pinacoteca do Estado e, no ano seguinte, mais dez pinturas dele e de outros artistas. Ver BARBUY, Heloisa. O Museu Paulista e a Pinacoteca do Estado. In: ARAUJO, Marcelo Mattos; CAMARGOS, Marcia. (Org.). Pinacoteca do Estado: a história de um museu/The History of the Museum. São Paulo: Artemeios, 2008,p. 144.

24 José de Freitas Valle era formado na Faculdade de Direito de São Paulo. Em 1895 foi nomeado subprocurador do estado de São Paulo, cargo que exerceu até sua aposentadoria. Era partidário do PRP, tendo sido eleito deputado e senador estadual. Foi graças à sua iniciativa que foi criado Pensionato Artístico do Estado de São Paulo, que selecionava jovens artistas e músicos para prêmios de viagem à Europa e subsidiava os seus estudos. Era um verdadeiro mecenas, que reunia políticos, intelectuais e
} 
estudantes de canto, música e artes plásticas, como descreve Marcia Camargos ${ }^{25}$. Os artistas beneficiados com a bolsa deveriam encaminhar à Pinacoteca obras que produzissem durante a sua estadia na Europa. Dessa maneira, o acervo predominante da instituição, até a década de 1930, era de obras dessa natureza, bem como as de salões de artes ou as que eram doadas ao museu por famílias da elite paulistana. Não havia diretrizes que orientassem a formação do acervo, já que se aceitava indiscriminadamente todo tipo de doação, sem critério algum. Dessa maneira, muitas vezes despejava-se na Pinacoteca obras que nem sempre tinham valor artístico reconhecido pelos críticos de então ${ }^{26}$.

A Pinacoteca foi, assim, um espaço muito polêmico durante seus primeiros anos de existência, pois era criticada pela falta de quadros "de valor artístico", bem como pela escassez de visitantes. As considerações feitas sobre a instituição eram, algumas vezes, divulgadas na imprensa, como a que ocorreu em outubro de 1919, no jornal O Estado de São Paulo, que publicou a carta de um leitor que relatou a sua experiência ao visitar a Pinacoteca, após ter lido sobre ela na coluna "coisas da cidade":

Li, com atenção as linhas que Ihe mereceu a Pinacoteca. Faz muito bem v. em chamar a atenção do público para certas "coisas da cidade" que, sem isso, ficariam completamente ignoradas. A Pinacoteca, por exemplo, sem a sua crônica, eu nunca a conheceria, com certeza, mas, lendo o que v. escreveu, quis logo ver também o que lá existe. É pouquíssimo e muito insignificante. Positivamente, aquilo não merece o nome de Pinacoteca, e quem Iho pôs não sabe absolutamente o que significa com exatidão esse vocábulo. Vá porém ao Larousse, e verificará que só merece ser assim chamada a galeria de arte que já tenha quadros em grande quantidade, de sorte que o nome galeria já não exprima bem a importância da coleção.

Como se chama, então, Pinacoteca a um conjunto de 90 quadros apenas? (...) A nossa coleção, pois, devia se denominar apenas - Galeria. (...)

Outra coisa: existem ali, entre os 90 quadros, muitos que não mereciam estar num salão particular, quanto mais numa galeria oficial de quadros! É que o governo manda para a Pinacoteca todos os quadros e estudos que Ihe oferecem os artistas. Mas não deve ser esse, absolutamente, o critério para a formação da nossa galeria de arte ${ }^{27}$.

toda uma geração de pintores, escultores, cantores e músicos em sua residência da Vila Mariana , conhecida como Vila Kyrial.

${ }^{25}$ CAMARGOS, Marcia. A Pinacoteca em oito tempos: um ensaio histórico In: ARAUJO, Marcelo Mattos; CAMARGOS, Marcia. (Org.). Pinacoteca do Estado: a história de um museu/The History of the Museum. São Paulo: Artemeios, 2008.

${ }^{26}$ CAMARGOS, Marcia. A Pinacoteca em oito tempos: um ensaio histórico In: ARAUJO, Marcelo Mattos; CAMARGOS, Marcia. (Org.). Pinacoteca do Estado: a história de um museu/The History of the Museum. São Paulo: Artemeios, 2008, p. 48.

${ }^{27}$ O Estado de São Paulo, 04 de outubro de 1919. 
É possível perceber, pelo relato do leitor do jornal, que a Pinacoteca não gozava de grande popularidade, situação que fica evidente pelo número de visitantes que, em 1928, ainda era ínfimo, sobretudo se comparado ao do Museu Paulista. O jornal Correio Paulistano, no dia 15 de julho de 1928, publicou que o número de visitantes da Pinacoteca do Estado no ano de 1928 foi crescente, completando 18.625 pessoas. Na mesma página, com muito mais louvor, foram também apresentados os números de frequentadores do Museu Paulista, que conseguiu atingir "o índice notável" de 243.658 visitantes. Na mesma nota, há ainda a seguinte descrição: "Patrimônio invejável da nossa história e das nossas artes, de que se orgulha justamente S. Paulo, o Museu Paulista já interessa o nosso povo e a curiosidade dos nossos visitantes" ${ }^{\prime 2}$. No exemplar de 28 de novembro de 1928 do jornal Correio Paulistano é dito que a Pinacoteca do Estado está fora de mão, mal instalada e ignorada e paga 24:000\$000 anuais de aluguel. Portanto, é evidente a insatisfação do periódico com essa instituição.

A despeito de todas as críticas ao acervo da Pinacoteca, era nela que se encontravam o quadro Partida da Monção, de Almeida Júnior, cobiçado por Affonso Taunay para figurar na Seção Histórica do museu, já que ele representava um importante tema para a história paulista. Dessa maneira, a fim de recompor as referências históricas evocativas da epopeia bandeirante e aproveitando-se do desprestígio pelo qual a Pinacoteca do Estado passava, Taunay pediu que a tela de Almeida Junior fosse transferida ao Museu Paulista.

O próprio Secretário do Interior, Fábio Barreto, e o Presidente do Estado de São Paulo, Julio Prestes, visitaram a Pinacoteca em outubro, como é relatado pelos jornais Correio Paulistano ${ }^{29}$ e pelo O Estado de São Paulo ${ }^{30}$. Ficou definido, então, que a obra seria transferida. Segundo Taunay, isso se justificava pela quantidade de visitantes nas duas instituições, como está explícito na correspondência que ele enviou ao Secretário do Interior:

Atendendo a determinação de V. Ex. ultimamente feita, cabe-me informar a $V$. Ex. que estou examinando os diversos meios de solução ocorrentes para a melhor colocação da obra prima de Almeida Junior "Partida da Monção", que V. Ex. e o Exmo. Snr. Presidente do Estado resolveram transferir para o Museu Paulista em vista da enorme

\footnotetext{
${ }^{28}$ Correio Paulistano, 15 de julho de 1928.

${ }^{29}$ Nota publicada no Correio Paulistano de 18 de outubro de 1928.

${ }^{30}$ Nota publicada em O Estado de São Paulo de 18 de outubro de 1928.
} 
diferença da frequência de visitantes entre Pinacoteca do Estado e a do nosso Instituto $^{31}$.

Foi possível acompanhar os trâmites para a transferência da obra por meio das correspondências entre Taunay e o Secretário do Interior. O diretor procurou relatar todos os esforços que estava empreendendo para adequar a sala em que a tela ficaria exposta, além de todos os cuidados que deveriam ser tomados para que o transporte ocorresse sem nenhum prejuízo ao quadro. Segundo Ana Claudia Brefe, o auge da epopeia criada por Taunay se consolidou justamente com a Sala das Monções, cujo ponto fulcral era a tela de Almeida Junior. Para compor a sala, Taunay encomendou a Oscar Pereira da Silva quadros que deveriam ser feitos a partir de desenhos de Hercules Florence e de um de Adriano Taunay, referentes à última fase das monções, registrados durante a expedição do barão Langsdorff, patrocinada pelo governo imperial russo no início do século $\mathrm{XIX}^{32}$. A escolha de Oscar Pereira da Silva para realizar os quadros da grande sala das Monções efetivada por Taunay demonstra que ele confiava no trabalho do artista, além de comprovar que havia um bom relacionamento entre os dois.

No dia 03 de abril de 1929, foi oficializada a transferência do quadro Partida da Monção, de Almeida Junior e, além deste, dos dois quadros de Oscar Pereira da Silva, Fundação de São Paulo e Desembarque de Pedro Álvares Cabral em Porto Seguro em $1500^{33}$.

Essas duas obras, entretanto, nunca foram citadas nas correspondências trocadas entre Taunay e Fabio Barreto. Assim, não é possível saber se o diretor do Museu Paulista havia requisitado as telas ou se a iniciativa havia partido do Secretário do Interior. É certo que havia um grande interesse, por parte do Estado, em transferir não só esses quadros, mas todo o acervo da galeria artística da Pinacoteca para o Museu Paulista. Taunay, porém, opunha-se veementemente a tal ideia, o que fica explícito na sua justifica apresentada no relatório anual de 1930:

Já por duas vezes foi a Diretoria do Museu interpelada sobre a conveniência do transporte da Pinacoteca do Estado para o Ipiranga. Fiz ver aos Secretários do Interior

\footnotetext{
${ }^{31}$ Correspondência 23 de novembro de 1928, acervo Museu Paulista da USP.

32 Segundo Ana Claudia Brefe, os quadros realizador foram: Carga dos canoões, Bênção dos canoões em Porto Feliz, Pouso de uma monção no sertão, Encontro de duas monções, Partida de Porto Feliz. Ver BREFE, Ana Claudia Fonseca. Museu Paulista, Affonso de Taunay e a memória nacional (1917 - 1945). São Paulo: Editora Unesp: Museu Paulista, 2005, p. 240-241.

${ }^{33}$ A transferência foi oficializada por meio do ofício 159 que a Secretaria do Interior encaminhou à Pinacoteca solicitando que fosse entregue ao Liceu de Artes e Ofícios, para serem transportados ao Museu Paulista. O documento encontra-se no acervo do Centro de Documentação e Memória do Museu Paulista.
} 
a absoluta impossibilidade de se pensar em tal remoção. O Palácio do Ipiranga é todo em fachada, dispõe de insignificante profundidade. Nos dois primeiros andares metade da área é tomada pelos corredores e galerias. O que resta pois certo número de salas, geralmente não grandes, corresponde a pequenas superfícies se levarmos em conta que o Museu dispões hoje de imenso material digno de exposição ${ }^{34}$.

A análise desse documento demonstra a insistência da secretaria que, segundo Taunay, havia pedido duas vezes ${ }^{35}$ para que a remoção ocorresse. Ademais, é possível perceber que o diretor do Museu Paulista não aceitava facilmente qualquer solicitação, utilizando-se, quase sempre, da justificativa de falta de espaço. É possível depreender, portanto, que deve ter havido interesse da Secretaria do Interior em transferir as telas de Oscar Pereira da Silva para o Museu Paulista e que por representarem "assuntos históricos", assim como a Partida da Monção, seriam mais compatíveis com o projeto desse museu do que da Pinacoteca.

É certo também que Taunay não apresentou resistência à transferência, já que aceitou os quadros em sua instituição, a despeito da "falta de espaço" sempre alegada por ele. As obras, entretanto, não foram recebidas com o mesmo louvor que a tela de Almeida Junior. Ao contrário, a transferência foi feita de maneira muito discreta e sem alardes. Nem mesmo a grande imprensa divulgou notas sobre o acontecimento ${ }^{36}$. Além disso, o próprio diretor demonstrou-se indiferente com os quadros, como é possível perceber no excerto

Recebo a informar uma conta do Liceu de Artes e Ofícios enviada a essa Secretaria ao transporte da Partida da Monção e mais duas grandes telas da Pinacoteca do Estado ao Museu Paulista.

Realmente está a conta exata. Por ordem verbal do Exmo. Snr. Secretario do interior recebi a incumbência de tratar com o Liceu a desmontagem especial acondicionamento transporte nova adaptação e remontagem no Museu dos três grandes quadros a que se refere a conta ${ }^{37}$.

\footnotetext{
${ }^{34}$ Relatório Anual do Museu Paulista de 1930, p. 4.

${ }^{35}$ Posteriormente, a Secretaria do Interior insistiu ainda uma vez no pedido de remoção, como é possível acompanhar no relatório anual no Museu Paulista de 1931.

${ }^{36}$ A pesquisa procurou nos jornais Correio Paulistano e O Estado de São Paulo, porém, não encontrou nenhuma nota sobre a transferência.

${ }^{37}$ Correspondência de 27 de abril de 1929, Acervo do Museu Paulista da USP.
} 
A carta é muito reveladora, já que faz referência às obras como "mais duas grandes telas", sem nem ao menos citar seus títulos, fato que se repete em outros documentos $^{38}$. Além disso, no relatório anual de 1929 não há nenhuma menção às telas, já que elas não foram citadas nas aquisições do museu, nem nas "dádivas" ${ }^{39}$ recebidas. A respeito das inaugurações que ocorreram naquele ano, os quadros não foram mencionados nem no relatório anual, nem na imprensa, prática que era recorrente, como se pode notar, por exemplo, na divulgação da abertura da Sala das Monções, que foi tema de um longo artigo ${ }^{40}$ do jornal Correio Paulistano. Até mesmo a inauguração das ânforas contendo águas dos principais rios brasileiros foi tema de divulgação da imprensa ${ }^{41}$. A transferência e a inserção da Fundação de São Paulo no Museu Paulista foram, entretanto, completamente "esquecidas".

Apesar desse silêncio, é importante ressaltar que para a obra de Oscar Pereira da Silva, a transferência representou um importante passo na sua trajetória, uma vez que ela saía de uma instituição de pouco prestígio e pouco frequentada para ganhar espaço no museu que era, naquele momento, o grande alvo da mídia, além de ser a instituição que se propunha a contar a história da nação a partir do protagonismo paulista, narrativa que era construída por meio das imagens didaticamente eficientes. A transferência representou, assim, uma mudança da característica que seria priorizada na obra, pois ela passou a cumprir a função para a qual havia sido gestada - um documento histórico da origem do povo paulista e do estabelecimento do núcleo urbano no planalto do Piratininga, função que havia sido relegada a segundo plano desde a sua inserção na Pinacoteca do Estado, em 1909.

O espaço disponível no Museu Paulista que Taunay acreditou mais adequado para inserir a tela Fundação de São Paulo foi na Sala A-15, que era aquela

\footnotetext{
${ }^{38}$ Até no orçamento pedido para a realização da transferência das obras há a seguinte descrição: "Desmontagem, especial acondicionamento, transporte e nova adaptação e montagem no Museu do grande quadro "A partida da Monção" existente na Pinacoteca do Estado. Transporte e colocação de 2 quadros menores". Como é possível notar, não se referem às obras pelo título, além disso,o tratamento

39 Todas as doações que o Museu recebia eram descritas na sessão chamada "dádivas" no relatório anual. Era comum também as doações fossem divulgadas nos jornais, principalmente no Correio Paulistano.

${ }^{40}$ No exemplar de 07 de agosto de 1929 do Correio Paulistano, é relatada a transferência da tela, que se justifica pela freqüência do Museu Paulista ser "quiçá doze vezes mais avultada" do que a Pinacoteca. Além disso, é descrito tudo que há na sala: além da "obra prima" do artista ituano, encontam-se os cinco desenhos de Florence e Taunay, "rigorosamente reproduzidos em óleo" por Oscar P. da Silva e Aurélio Zimmermann; um beque dede proa de uma canoa de monção, uma âncora da antiga navegação fluvial do Tietê e Paraná, ânfora contendo a água do rio Tietê.

41 O jornal O Estado de São Paulo publicou um artigo no dia 29 de abril de 1930 divulgando a inauguração de vasos que continham águas dos rios brasileiro. A pretensão do diretor da instituição fica explícita nas palavras divulgadas no periódico: "Com a colocação de oito novos e grandes vasos de bronze nas pilastras da escadaria monumental do Museu Paulista, completa-se uma das decorações simbólicas do grandioso "hall" do palácio do Ipiranga - certamente o mais belo do Brasil - tendo-se em vista uma síntese da unidade territorial brasileira".
} 
consagrada ao passado da cidade, na qual se pretendia reconstituir os aspectos da antigos da urbe paulista. Era nela que se encontrava a maquete realizada por Bakkenist, que reconstituía os aspectos da cidade em 1840. Por meio dos inventários institucionais que o diretor organizou, e que relacionava todo o acervo que estava inserido em cada uma das salas de exposição, foi possível saber os objetos que compunham o espaço de representação da cidade antiga. O inventário de 1932 indica a seguinte relação de acervo disposto na sala $A 15$ :

\section{SALA DE EXPOSICÃO DA SECCÃO DE HISTORIA - A-15}

1- Fundação de S. Paulo - Óleo de Oscar Pereira da Silva - Removido da Pinacoteca do Estado (T. 3,23 x 1,28)

2- Largo do Ouvidor em 1858. Óleo de H. Manzo (T. 0.45×0,35).

3- Rua da Boa Morte e Carmo. Óleo - de Jonas Barros (T. 0,64 x 0,44)

4- Retrato de Joseph de Anchieta. Óleo de pintor anônimo; ap. uma tela de Gesú em Roma (T.. 0,60 × 0,50)

5- Um paulista e um mendigo (1821). Gravura da obra de Henderson $(0,28 \times 0,234$ est.)

6- Panorama do Piques (1862) bico de Penna de Oscar Martin Jesús $(0,39 \times 0,32)$

7- O velho mercado e a ilha dos Amores (1886) bico de Penna de Oscar Martin de Jesús $(0,39 \times 0,32)$

8- Jardim da Luz (1880) bico de Penna de Oscar Martin de Jesús $(0,39 \times 0,32)$

9- Panorama da cidade de S. Paulo - Estampa colorida de três vistas $(0,89 \times 0,65)$

10- Mapa do Caminho do Mar entre S. Paulo e o Cubatão $(2,93 \times 0,72)$

11- O campo da Luz (1886) bico de pena de Oscar Martin de Jesús $(0,39 \times 0,34)$

12- O Largo S. Francisco (1884) bico de pena de Oscar de Jesús $(0,39 \times 0,35)$

13- Planta da cidade de S. Paulo por Julio Martin (1890) $(1,17 \times 1,00)$

14- Vista da mineração do Jaraguá - Estampa da obra de John Mawe $(0,27 \times 0,32)$

15- Quadro com o opúsculo e estampa da história do bicho ou monstro que dizem trazido da America, etc. $(0,36 \times 0,30)$

16- Mapa anônimo. Parte do Governo de S. Paulo - copiado da Biblioteca Nacional (0, $70 x$ $0,51)$

17- Mapa anônimo copiado da Biblioteca Nacional (0,62 × 0,47)

18- Planta da cidade de S. Paulo (1868) - anônimo, impressa. Dr. C Rath $(0,53 \times 0,50)$

19- Mapa da Imperial cidade de S. Paulo (1855) - Obra do Dr. C Rath $(0,87 \times 0,63)$

20- Planta da cidade de S. Paulo - original da primeira planta da cidade autoria de Rufino Felizardo e Costa (1810) $(0,77 \times 0,60)$

21- Quadro com estandarte da Câmara Municipal de S. Paulo no século XVIII $(0,80 \times 0,78)$

22- Bois e rebanhos de carneiros (Sera). Óleo de F. Ruggero Pannerai (L 2,90 x 1,98). Dádiva do Conde de Lara

23- Coluna entalhada de um altar da Igreja do Colegio em S. Paulo (1,67 de alto: x 0,18 de diâmetro)

24- Marco ponto de partida para a demarcação do Rocio de S. Paulo- Alt. 0,74 - Larg 0,17; Comp. 0,17)

25- Uma maquete em gesso sobre estrado de madeira (Dim. A - 0,51; L 6,14 L5,52) procurando reconstituir o aspecto da parte central da cidade de S. Paulo em 1840. Trabalho do modelador Henrique Bakkenist, antigo funcionário do Museu, sob as indicações diretas do Diretor, Dr. Affonso de E Taunay. Protegida por uma balaustrada de $7,34+6,46+6,72+0,88+0,80$. Altura 1,08 
26- Os retratos dos viscondes de Indaiatuba que figuram nos lançamentos da página 60 e faziam parte dos objetos expostos na sala $A-14$, passaram a figurar na sala $A-15$, sob os nos. 26 e 27

27- .

28- Os retratos do Brig. Bernardo J. Pinto Gavião Peixoto que figura nos lançamentos da pagina no. 56 sob o no. 8, passa a fazer parte dos objetos expostos na sala A-15, sob o no. 28.

29- Retrato a óleo do Conselheiro Gavião Peixoto (Dems: 1,26 x 0,96). Dádiva do Dr. Octavio Gonzaga, digo de D. Maria da Gloria Gavião ${ }^{42}$.

Além dos objetos listados acima, havia ainda uma vitrine com leques antigos de senhoras paulistanas. Ao observar o acervo que compunha a Sala A-15, é possível perceber que há uma nítida prioridade para a representação da cidade no século XIX, sendo irrisório o número de objetos alusivos ao período colonial. Além disso, percebese que se privilegiava a representação espacial da cidade, presente nos desenhos das ruas, nos mapas, nas plantas e, sobretudo, na maquete. Existia, além disso, imagens de paulistas célebres do século XIX. A Igreja Católica aparecia em um plano secundário, representada apenas pelo quadro de José de Anchieta e pela coluna entalhada vindo da igreja do Pátio do Colégio.

O quadro Fundação de São Paulo passou, assim, a ser um documento do passado da cidade, por isso, foi inserido na Sala A15. Mas o que a imagem pretende informar sobre o ato fundacional da urbe, que teria ocorrido pela união entre índios e europeus sob a égide do catolicismo, como foi descrito no capítulo 1 desta dissertação, não estava em destaque no espaço em que ela se situava. Dessa maneira, o quadro aparece destoado do restante da sala. O cumprimento de sua função evocativa e pedagógica - demonstrar como teria surgido São Paulo e o povo paulista - é, portanto, exígua e descontextualizada. Este é um aspecto que merece ser aqui aprofundado, pois pode oferecer ferramentas capazes de esclarecer o que poderia ter motivado o desconforto e o silêncio em relação às obras de Oscar Pereira da Silva quando da sua transferência ao Museu Paulista.

\footnotetext{
${ }^{42}$ Inventário do Museu Paulista de 1932, p. 58-60, Acervo do Museu Paulista da USP.
} 


\section{A inadequação de uma imagem adequada}

É fácil compreender que a tela Desembarque de Pedro Álvares Cabral em Porto Seguro em 1500 encontrasse dificuldade de inserção na narrativa criada por Taunay, pois, como já foi debatido no capítulo 2 desta dissertação, o episódio representado no quadro não contemplava os colonos pioneiros como protagonistas. $A$ pintura estava, portanto, em evidente dissonância com o restante das obras que pretendiam contar a história do Brasil por meio dos feitos dos paulistas.

É importante notar que a exposição criada por Taunay mencionava e louvava a união do índio com o europeu, mas Igreja e a ação dos missionários jesuítas haviam sido praticamente omitidas. As comemorações das efemérides vicentinas ${ }^{43}$ e a doação de padrão de Cananéia ${ }^{44}$ constituíram-se como justificativas para realizar novas inaugurações no museu, como demonstrou Ana Claudia Brefe. Foram, assim, obtidas quatro telas, de autoria de Wasth Rodrigues, que pretendiam evocar os primórdios da colonização ao representarem as autoridades que determinaram a conquista das terras de São Paulo e também os patriarcas das famílias paulistas de elite. Dessa maneira, foram pintados os retratos de D. João III, o rei de Portugal que tomou a decisão de povoar as terras brasileiras, mandando dividi-las em capitanias hereditárias; Martim Afonso de Souza, responsável pela capitania em que se fundou a Vila de São Vicente em 1532, e alguns anos depois, a Vila de Piratininga, futura cidade de São Paulo; João Ramalho, que teria auxiliado a missão colonizadora, facilitando o contato com os índios que habitavam a região além de ter iniciado o processo de miscigenação da "raça paulista"; e Tibiriçá, chefe de uma das principais tribos indígenas que habitavam os campos de Piratininga, com a qual João Ramalho estabeleceu laços bastante estreitos ao unir-se a uma das filhas do cacique ${ }^{45}$.

Essas telas foram colocadas no hall de entrada, juntamente com as estátuas dos bandeirantes Antônio Raposo Tavares e Fernão Dias Paes Leme, feitas pelo artista italiano Luiz Brizollara uma década antes, em 1922. Tais quadros eram, portanto, o ponto inicial da narrativa de Taunay, já que representavam os primeiros

\footnotetext{
${ }^{43}$ As duas efemérides referem-se ao aportar de Martim Afonso de Souza em Cananéia, em 1531, e a fundação de São Vicente, em 1532.

44 Segundo Ana Claudia Brefe, em 1930, Taunay colocou no alto do primeiro lance da escadaria monumental, logo abaixo da estátua de D. Pedro I e sobre um pedestal de mármore e bronze, um dos velhos marcos de pedra quinhentista proveniente do litoral de Cananéia, que havia sido doado pelo prefeito daquela cidade em 1927, depois de ter sido resgatado do fundo do mar, para onde havia rolado em meados do século XIX. BREFE, Ana Claudia Fonseca. Museu Paulista, Affonso de Taunay e a memória nacional (1917 - 1945). São Paulo: Editora Unesp: Museu Paulista, 2005, p. 251-252.

45 BREFE, Ana Claudia Fonseca. Museu Paulista, Affonso de Taunay e a memória nacional (1917 1945). São Paulo: Editora Unesp: Museu Paulista, 2005, p. 253-254.
} 
colonizadores e os precursores da gente de São Paulo ${ }^{46}$, sintetizado na figura da criança mestiça que aparece junto de João Ramalho e Tibiriçá. Ali estava o ponto original: a síntese entre gentio e europeu, que formavam o povo paulista, mameluco e bandeirante, desbravador do território. O ponto de chegada inevitável do percurso cenográfico concebido por Taunay era o quadro de Pedro Américo, Independência ou morte, evidência final de um processo formador da nação que tinha sido iniciado no solo de São Paulo, pelos primeiros povoadores mestiços de um novo povo que se desenhava no século XVI vicentino e paulista.

Figuras como Martim Afonso de Souza, João Ramalho e Anchieta disputavam nos discursos de historiadores e políticos o título de fundador da cidade. Ferreti e Capelato demonstraram as controvérsias geradas no IHGSP, sobretudo, diante da figura de João Ramalho ${ }^{47}$. Pretendia-se construir a identidade acomodando as diversas figuras sob um único e coerente panteão, reservando lugar especial e de destaque para aqueles heróis reputados mais significativos.

Ferreti e Capelato afirmam que, a partir dos anos 1920, quando a hegemonia político-econômica de São Paulo passou a ser contestada, houve um grande investimento na identificação de São Paulo como cerne e construtor da nacionalidade brasileira. Dessa maneira, historiadores ligados ao Partido Republicano Paulista Alfredo Ellis Jr., Affonso Taunay e Alcântara Machado - se encarregaram de propagar uma versão própria da identidade paulista. Com isso, rompeu-se definitivamente a postura conciliadora, que procurava unir "Jesuítas e Ramalhos", e a figura do Bandeirante assumiu um lugar de proeminência incontestável. João Ramalho assumiu definitivamente o posto de verdadeiro fundador da estirpe paulista, justamente por ser considerado o "primeiro bandeirante", por isso, assumiu o lugar primordial no Panteão dos Heróis. Em contrapartida, a imagem do jesuíta passou a ser atacada e, aos pouco, deixada em uma posição secundária em relação aos outros mitos fundadores.

Seguindo essa premissa, toda a narrativa criada no Museu Paulista conferia um papel periférico à Igreja e à fé cristã, sendo que a ação missionária durante o

\footnotetext{
${ }^{46}$ Nas palavras de Taunay ao se referir aos quarto painéis: "Relembram os vultos essenciais do quinhentismo paulista: o Rei povoador e seu grande delegado americano da colonização inicial, os patriarcas europeu e americano dos mais velhos troncos vicentinos. Nos dois últimos painéis figura simbolicamente o mesmo pequenino mameluco, ao lado de seu pai luso e do seu avô brasílico", TAUNAY, Affonso De E. Guia da Secção Histórica do Museu Paulista. São Paulo: Imprensa Official do Estado, 1937, p. 57.

${ }^{47} \mathrm{Na}$ passagem do século XIX para o XX houve uma grande contenda sobre a figura de João Ramalho. Alguns membros do IHGSP defendiam que ele era analfabeto, outros acreditavam que ele era da nobreza portuguesa. Este debate foi explorado no capítulo 1. Para mais informações ver FERRETYI, D. J. Z.; CAPELATO, M.H.R. João Ramalho e as origens da nação: os paulistas nas comemorações do IV Centenário da Descoberta do Brasil. Tempo, Niterói, 8, p. 67-87, dez. 1999.
} 
período de colonização foi praticamente omitida. Essa já é uma grande evidência que o protagonismo que Oscar Pereira da Silva atribuiu ao catolicismo em sua grande obra histórica encontrava problemas e desacordos com os eventos e figuras selecionadas por Taunay para compor a história contada no Museu Paulista. De maneira geral, eram muito escassas as referências aos jesuítas nesta instituição, já que as únicas representações iconográficas que faziam referência a eles eram dois retratos de Anchieta, um deles ${ }^{48}$, já citado aqui, exposto na Sala $A 15$, e outro ${ }^{49}$, feito por Benedito Calixto, que se encontrava na sala $\mathrm{A} 10$, dedicada à cartografia colonial e documentos antigos Havia ainda duas cartas escritas por José de Anchieta, doadas por Paulo Prado em $1927^{50}$, que ficavam na galeria oeste, próximas a uma vitrine com documentos quinhentistas; e peças da anchietana ${ }^{51}$, como biografias e processos de canonização.

Todos esses documentos haviam sido organizados e expostos para as comemorações do 4ํ. centenário do nascimento de José de Anchieta em 1934, ocasião que em que foram organizados eventos em vários pontos da cidade. O Museu Paulista participou dos festejos com a abertura da exposição dos documentos que a instituição tinha do padre jesuíta, como foi relatado pelo jornal O Estado de São Paulo, em 16 de março de 1934. Taunay afirmou no relatório anual da instituição que, por delegação do Secretario da Educação Christiano Altenfelder Silva, ele havia sido incumbido de orientar as comemorações no estado ${ }^{52}$.

Nenhum dos referidos objetos e retratos foi adquirido por iniciativa direta de Taunay. Ademais, nota-se que Anchieta foi o único missionário contemplado no Museu

\footnotetext{
${ }^{48}$ Taunay descreve o quadro como: "um retrato da velhice de Anchieta, copiado do que se acha na Igreja do Gesú em Roma. TAUNAY, Affonso De E. Guia da Secção Histórica do Museu Paulista. São Paulo: Imprensa Official do Estado, 1937, p.88.

49 Segundo Fábio Rodrigo de Moraes, o quadro de Anchieta foi encomendado durante a gestão de Hermann von Ihering. Segundo o autor, o ano de 1901 seria "o mais eloqüente indicador da importância conferida às coleções artísticas e históricas do museu foi a primeira encomenda de duas obras a Benedito Calixto, tendo o Museu pago 1:000\$000 de Réis por cada uma, quantia equivalente a um mês da verba de expediente da instituição, sendo as obras um retrato de D. Pedro I e outro do Pe. José de Anchieta" MORAES, Fábio Rodrigo de. Uma coleção de história em um museu de ciências naturais: o Museu Paulista de Hermann von Ihering. Anais do Museu Paulista: História e Cultura Material, São Paulo, v. 16, n. 1 , jan.-jun. 2008, p. 214

50 Interessante notar que esses documentos não passaram a compor o acervo do Museu Paulista por iniciativa de seu diretor, mas por iniciativa de Paulo Prado, representante da elite paulista. A compra foi realizada por meio da subscrição promovida pelo quinzenário modernista de São Paulo, Terra roxa e outras terras. $\mathrm{O}$ documento estava em um antiquário londrino e foi trocado por trinta sacas de café, que era o equivalente a duzentas libras esterlinas, e que foram doadas por fazendeiros paulistas. BREFE, Ana Claudia Fonseca. Museu Paulista, Affonso de Taunay e a memória nacional (1917 - 1945). São Paulo: Editora Unesp: Museu Paulista, 2005, p. 255-256.

51 Sobre esses documentos, Taunay diz: "numa vitrina especial, diversas peças, algumas delas raras, da anchietana; entre outras, diversas biografias, o processo de canonização, etc". TAUNAY, Affonso De E. Guia da Secção Histórica do Museu Paulista. São Paulo: Imprensa Official do Estado, 1937, p.67.

52 Relatório Anual do Museu Paulista, 1934, p. 37, acervo do Museu Paulista da USP
} 
Paulista. Não fosse por sua rara aparição nesses documentos, os jesuítas haveriam sido completamente omitidos da história paulista veiculada pela instituição. Em 1929, Lucílio de Albuquerque ofereceu ao diretor seu quadro $A$ catequese, pela quantia de cinco contos de réis e afirmou que além da honra da tela figurar naquele museu, isto Ihe traria grande vantagem naquele momento ${ }^{53}$. Além disso, essa obra poderia complementar a narrativa de Taunay, preenchendo a lacuna que existia sobre o papel dos jesuítas na colonização do Brasil. O diretor, no entanto, não demonstrou interesse pelo quadro. Outros inacianos como o padre Manuel da Nóbrega e o padre Manuel Paiva, que exerceram ação de destaque na aldeia instalada em Piratininga, não foram sequer mencionados na narrativa do museu. Não é de se estranhar, portanto, que o quadro de Oscar Pereira da Silva não se adequasse às expectativas de Taunay.

Outro aspecto que merece ser destacado nesse contexto é a perda de significação do Pátio do Colégio, espaço em que teria ocorrido a fundação de São Paulo. Desde 1776, o local havia sido destinado às atividades do governo da capitania $^{54}$ e, como foi explorado no capítulo 2 desta dissertação, desde 1896 a igreja do Bom Jesus foi derrubada, eliminando-se a última evidência de passado religioso no logradouro. Com isso, gradativamente, a denominação "Pátio do Colégio" desapareceu, evidenciando a ausência da religiosidade do antigo terreiro dos jesuítas, que passou a ser denominado desde o século XIX de Largo do Palácio. Solange Ferraz de Lima ao analisar fotografias e cartões postais que mostram este espaço da cidade percebe claramente este processo ${ }^{55}$. Segundo a autora, a partir de 1891, a menção ao Palácio do Governo começa a ser realçado, fato muito notável nas legendas que se referem, sobretudo, ao Largo do Palácio ou ao Jardim do Palácio enquanto poucos trazem a imagem e a identificação da Igreja. O completo banimento das funções religiosas ocorrido em 1896, "que promoveu a primeira lacuna nas significações sociais imediatamente associadas ao pátio - o poder da Igreja na organização da cidade colonial e a lembrança de seus fundadores" ${ }^{56}$ selou o processo.

A inauguração das sedes das Secretarias da Justiça e da Agricultura, bem como as alterações arquitetônicas ocorridas já no século XIX na fachada do antigo colégio dos jesuítas, fizeram com que o pátio perdesse totalmente sua expressão como marco religioso. Dessa maneira, segundo Lima, a área passou a ser conhecida

\footnotetext{
${ }^{53}$ Correspondência enviada por Lucilio Albuquerque ao diretor do Museu Paulista em 18 de abril de 1929, acervo do Museu Paulista da USP.

54 LIMA, Solange Ferraz de. Pátio do Colégio, Largo do Palácio. Anais do Museu Paulista, (São Paulo). Nova série, v. 6/7 (1998-1999). Editado em 2003, p. 64.

${ }^{55}$ Idem, p. 67-69.

${ }^{56}$ Idem, p. 70.
} 
somente como centro político e cívico. Entretanto, a situação de perda de função simbólica agravou-se na década de 1930, quando a sede do governo foi definitivamente transferida para os Campos Elísios, enquanto o palácio passou a ser ocupado pela Secretaria da Educação ${ }^{57}$. O Pátio do Colégio perdeu, então, o que lhe restava de identidade, já que deixou de ser marco representativo da política e administração da cidade.

Além disso, o fato da praça ter sido reformulada em 1925 com a inauguração do monumento Glória Imortal aos Fundadores de São Paulo, projetado em 1913 por Amadeu Zani, reduziu a relação daquele espaço público a momentos transitórios. Como bem demonstrou Lima:

marcar fisicamente o lugar de fundação com um dispositivo de memória coletiva representa, na verdade, o esvaziamento de todas aquelas práticas que dotavam este espaço de sua carga simbólica e ativa em significações e usos. Essa memória de efeméride, reduzida à fruição em trânsito, cumpre uma função pretensamente compensatória da perda que a "vocação" de circulação imputou aos usuários da cidade e desse espaço em particular ${ }^{58}$.

O lugar da origem de São Paulo havia, pois, se esvaziado de significação. Isso tornava a imagem de Oscar Pereira da Silva ainda mais deslocada dessa nova configuração do Pátio do Colégio, em que nem a religião nem as construções religiosas exerciam papel fundamental na cidade. O Pátio do Colégio perdia sua carga simbólica na cidade de São Paulo, assim como a tela de Oscar Pereira da Silva tinha uma função acessória na narrativa de Taunay.

Um aspecto que chama a atenção na organização da seção de história do Museu Paulista é o fato de existir outra sala consagrada ao passado da cidade, a A11, em que eram dispostos documentos do período colonial, como as atas da Câmara e do seu Registro Geral, de 1562 a 1882. Havia códices que relembravam os fatos considerados relevantes da história de São Paulo, como termos de vereação e registros dos assaltos dos índios tamoios em 1562, as lutas com os índios do planalto, no século XVI, a elevação de São Paulo à categoria de cidade, entre outros. Havia também uma coleção de plantas da cidade e diversos mapas. Estavam expostos

\footnotetext{
${ }^{57}$ Segundo Solange Ferraz de Lima, já no início dos anos 1900 a residência dos governadores havido sido transferida para o chamado Palácio dos Campos Elísios, palacete que o Estado adquirira da família de Elias Chaves, situado na esquina da Alameda Glette com a Avenida Rio Branco, no bairro Campos Elíseos.

58 LIMA, Solange Ferraz de. Pátio do Colégio, Largo do Palácio. Anais do Museu Paulista: História e Cultura Material, São Paulo, , v. 6/7 (1998-1999). Editado em 2003, p. 71.
} 
diversos quadros que representavam edifícios e logradouros desaparecidos da metrópole, como a Câmara de São Paulo em 1628, a rua da Imperatriz em 1858, o largo da Misericórdia, entre outros. Também era ali que estava situado o quadro que denominara $A$ grande inundação das Várzeas ${ }^{59}$, feito por Benedito Calixto que, segundo Taunay, constituía um precioso documento de época relativo ao ano de 1892. Como o próprio diretor escreveu sobre as imagens expostas nessa sala: os quadros (...) representam trechos, muitos dos quais, senão quase todos, hoje absolutamente irreconhecíveis pela transformação arquitetônica por que passaram ${ }^{60}$.

Percebe-se, assim, que a sala A11 tinha uma conotação um pouco diferente da A15. Apesar de ambas conterem quadros com cenas de ruas e pontos importantes da cidade, a primeira enfatizava o aspecto histórico, sobretudo, pelos documentos ali expostos. Já a sala A15 priorizava o aspecto espacial da urbe, reconstituindo a cidade, como é possível perceber pelo subtítulo que o próprio Taunay atribuía à sala - ensaio de reconstituição dos aspectos da cidade em 1840. Por que obra de Oscar Pereira da Silva estaria, então, nesta e não na outra sala?

O fato de Taunay não ser afeito a enfatizar o catolicismo e à ação missionária pode ter sido o motivo pelo qual a tela foi exposta na sala em que o grande protagonista era a própria cidade. Dessa maneira, o papel desempenhado pelos jesuítas ficava reduzido a mero intermediário do processo de estabelecimento da vila, pelo que a tela de Oscar Pereira da Silva ficava incumbida apenas da representação do estabelecimento da urbe. Deixava, assim, de exercer a função a que havia sido proposta inicialmente, que era a de representar o evento primordial e embrionário, não apenas da cidade no aspecto territorial, mas da gênese de São Paulo, dos paulistas e, por extensão, de todo o Brasil.

De qualquer forma, em 1929, a Fundação de São Paulo passou a pertencer ao acervo do Museu Paulista por meio de uma transferência silenciosa, visto que apresentava um discurso contrastivo ao projeto de exposição elaborado por Taunay. A despeito desses percalços, a sua inserção nessa instituição constituiu uma etapa fundamental na trajetória da obra, que ganhou uma projeção muito maior do que a que tinha na Pinacoteca além de ter sido, a partir de então, realçada a dimensão histórica

\footnotetext{
${ }^{59}$ Taunay descreve o quadro da seguinte maneira: "Grande tela de Calixto, com uma superfície de mais de oito metros quadrados $A$ Grande inundação das várzeas em 1892, traduz hoje irrealizável e é precioso documento da época", nos leva a crer que ele esteja se referindo á obra que hoje é conhecida pelo nome de Inundação da Várzea do Carmo em 1892. Ver TAUNAY, Affonso De E. Guia da Secção Histórica do Museu Paulista. São Paulo: Imprensa Official do Estado, 1937, p.76. A tela é atualmente denominada Inundação da Várzea do Carmo.

${ }^{60}$ TAUNAY, Affonso De E. Guia da Secção Histórica do Museu Paulista. São Paulo: Imprensa Official do Estado, 1937, p.77.
} 
a ela vinculada, motivo pelo qual passou a ser muito reproduzida desde a década de $1930^{61}$

Nesse período, a obra ganhou ainda mais visibilidade quando foi reproduzida em vitral e passou a compor a decoração da Faculdade de Direito, cujo prédio foi reconstruído a partir da década de 1930. Como afirma Diego Amorim Grola, Alcântara Machado, diretor da faculdade desde 1931, apontava a inadequação do velho edifício conventual, que não apresentava condições de higiene e conforto, além de precisar de mais espaço e salas mais adequadas ${ }^{62}$. Propôs-se, assim, uma reforma no prédio, que seguiu o projeto de Ricardo Severo, engenheiro-arquiteto português, sucessor de Ramos de Azevedo em seu escritório. Ana Luiza Martins e Heloísa Barbuy demonstram que a Faculdade de Direito tinha consciência de ser uma instituiçãochave na construção do país, inclusive do regime republicano. Sentiu-se, assim, na premência de modernizar-se, sobretudo, diante do contexto político da era Vargas, momento em que a Primeira República sofria duras críticas, sendo adjetivada de Velha, juntamente com a mentalidade jurídica que havia comandado o país até $1930^{63}$. A reforma, que acabou por se transformar em completa demolição do antigo convento e construção de novo edifício, tinha como objetivo não apenas ampliar as instalações e garantir a salubridade, mas combater essa visão negativa da instituição, porém, sem perder seu caráter de tradição:

Preservar a história e seu valor simbólico implicava modernizar-se, inserir-se na nova conjuntura, sob a pena de ficar para trás, já sem força de atuação. Certo ou errado, o fato é que optou-se pela demolição do convento e a construção de um novo edifício. Acreditou-se que um prédio novo e imponente, com instalações mais adequadas em proporção e qualidade, garantiria a inserção da faculdade nos novos tempos ${ }^{64}$.

O novo edifício projetado por Ricardo Severo seguia parâmetros do estilo neocolonial, tendência que surgiu nas primeiras décadas do século $\mathrm{XX}$, que procurava

\footnotetext{
${ }^{61}$ O próprio Taunay ressalta esse aspecto da obra, quando a descreve na sala A15. "A notar-se nesta sala a grande tela de Oscar Pereira da Silva: A fundação de São Paulo, a 25 de janeiro de 1554, popularizada pela reprodução freqüente". TAUNAY, Affonso De E. Guia da Secção Histórica do Museu Paulista. São Paulo: Imprensa Official do Estado, 1937, p. 88.

62 GROLA, D. A. A memória nas Arcadas: construção material, simbólica e ideológica do edifício da Faculdade de Direito do Largo de São Francisco. São Paulo: Humanitas/Fapesp, 2012.

${ }^{63}$ MARTINS, Ana Luiza. BARBUY, Heloísa. Arcadas: história da faculdade de direito da Universidade de São Paulo. São Paulo: Companhia Melhoramentos: Alternativa Serviços Programados, 1999, p.177.

${ }^{64}$ MARTINS, Ana Luiza. BARBUY, Heloísa. Arcadas: história da faculdade de direito da Universidade de São Paulo. São Paulo: Companhia Melhoramentos: Alternativa Serviços Programados, 1999, p. 177.
} 
afirmar a nacionalidade brasileira por meio da busca das raízes de nossa arquitetura, retomando elementos da arte construtiva do período colonial, que haveriam sido marginalizados durante o Império e a República. Introduziam-se nas construções do presente os motivos representativos das construções pretéritas ${ }^{65}$. Severo propôs, assim, uma adoção da "Arte Tradicional"66 para o novo edifício da Faculdade de Direito, que deveria conjugar tradição e modernidade, já que as soluções empregadas deveriam atender às necessidades de uma instituição de ensino da primeira metade do século XX, principalmente na disposição interna dos espaços, porém, com uma ornamentação e elementos arquitetônicos ${ }^{67}$ que expressassem a nacionalidade brasileira. Segundo o próprio engenheiro, o estilo então adotado foi o barroco-jesuítico implantado no Brasil pelos seus primeiros construtores ${ }^{68}$.

Grola afirma que a ornamentação empregada no edifício consistiu em uma releitura dos motivos decorativos da arquitetura colonial luso-brasileira, que tinha como objetivo tornar a faculdade mais evocativa do passado colonial do que originalmente era. O estilo arquitetônico adotado denotava a tentativa de afirmar um lugar de importância para a Faculdade na história da nação, tornando-se uma espécie de museu da arte colonial, que cumpriria o papel de perpetuar os tipos característicos da tradição arquitetônica brasileira. Constituía-se, portanto, como um espaço simbólico de consolidação da nacionalidade, que buscava legitimar o papel da Academia na formação da nação ${ }^{69}$.

Além da ornamentação arquitetônica, foi concebida uma série de vitrais, realizados pela Casa Conrado, que se apresentam em sequência na Escadaria e que constituem, como afirmam Martins e Barbuy, uma alegoria de uma História do Brasil, fundamentada pelo Direito e por valores universais. A fonte de inspiração da narrativa visual que ali se reproduzia foi o Museu Paulista, pois foram utilizadas três obras de seu acervo, que conferiam força ao conjunto. No térreo, a imagem central é a memória

\footnotetext{
65 GROLA, D. A. A memória nas Arcadas: construção material, simbólica e ideológica do edifício da Faculdade de Direito do Largo de São Francisco. São Paulo: Humanitas/Fapesp, 2012, p. 140-141.

${ }^{66}$ Segundo Diego Grola, o estilo neocolonial era chamado de "Arte Tradicional"por Ricardo Severo. Ver GROLA, D. A. A memória nas Arcadas: construção material, simbólica e ideológica do edifício da Faculdade de Direito do Largo de São Francisco. São Paulo: Humanitas/Fapesp, 2012, p. 140.

${ }^{67}$ Segundo Diego Grola, "os principais elementos tradicionais destacados por Severo, e empregados em seus projetos tradicionais, são: escada externa de acesso à edificação; verandas; patios internos; janelas com rótulas; telhados de beiral prolongado; além de elementos ornamentais, como frontões, molduras de portas e janelas e paineis de azulejaria”. Ver GROLA, D. A. A memória nas Arcadas: construção material, simbólica e ideológica do edifício da Faculdade de Direito do Largo de São Francisco. São Paulo: Humanitas/Fapesp, 2012, p. 170.

68 GROLA, D. A. A memória nas Arcadas: construção material, simbólica e ideológica do edifício da Faculdade de Direito do Largo de São Francisco. São Paulo: Humanitas/Fapesp, 2012, p.163-164.

${ }^{69}$ Idem, p. 178-181.
} 
do convento juntamente com as igrejas franciscanas. Ele está ladeado por duas alegorias: a Filosofia e a Justiça, que representam o fundamento do pensamento jurídico que sustenta a nação. No primeiro andar, o tríptico representa a gênese paulista. O vitral central é o do quadro de Oscar Pereira da Silva, Fundação de São Paulo, portanto, o fundamento da urbe. Ele está acompanhado de uma vista do Pátio do Colégio no século XIX, quando representava a capital administrativa e política, e também da Partida da Monção, de Almeida Junior, que evoca a conquista do território ocidental pelos paulistas. No segundo andar, encontra-se o vitral alusivo a Independência ou morte!, de Pedro Américo, simbolizando o nascimento da nação, cujo ato de bravura ocorrera em solo paulista. O que finaliza o conjunto, no terceiro andar, é a Lei das XII Tábuas, que está acompanhada das alegorias da Força e da Temperança, que representam o próprio Direito $^{70}$.

A trajetória criada por meio dos vitrais integra a História Nacional a valores universais, que estão associados ao Direito, como a Força, a Temperança, a Filosofia e a Justiça. A história da nação parte do estabelecimento de São Paulo e culmina com a emancipação política brasileira, e é construída pelos quadros Fundação de São Paulo, Partida da Monção e Independência ou morte!, que compõem também o acervo do Museu Paulista. Porém, se nessa instituição a origem está associada à miscigenação, representada pelos quadros de Tibiriçá e de João Ramalho, na Faculdade de Direito, a gênese é a benção realizada em 25 de janeiro de 1554, cuja imagem foi concebida por Oscar Pereira da Silva. Com isso, a Fundação de São Paulo ganhava visibilidade e proeminência, pois além de decorar o prédio da instituição que pretendia ser símbolo da modernidade e da tradição, representava o ato primordial da história ali narrada. Constituía-se como imagem inicial da narrativa paulista, que era, por extensão, de toda a nação.

\section{Triunfo de uma imagem urbana}

O ano de 1954 foi crucial para a afirmação simbólica paulista e paulistana por meio da evocação do passado, pois se comemorou o quarto centenário da fundação da cidade de São Paulo, efeméride marcada por festividade e eventos, que não ficaram restritos ao dia 25 de janeiro. Ao longo de todo o ano, foram realizadas conferências, espetáculos, desfiles, além de terem sido inaugurados diversos edifícios e monumentos. Como apontou Silvio Luiz Lofego, o controle da memória era uma

\footnotetext{
70 MARTINS, Ana Luiza. BARBUY, Heloísa. Arcadas: história da faculdade de direito da Universidade de São Paulo. São Paulo: Companhia Melhoramentos: Alternativa Serviços Programados, 1999, p. 190-192.
} 
estratégia vital das classes dominantes, pois o simbolismo e o resgate do passado era a melhor maneira de criar a identidade desejada para o presente. Escolher o que deve ser lembrado e esquecido é um mecanismo fundamental para a manipulação da memória coletiva, portanto, é instrumento de legitimação do poder. Nesse sentido, a Comissão do IV centenário procurou coletar e habilitar os "lugares da memória" paulistana e construir símbolos para a materialização da história que se escrevia ${ }^{71}$. 0 IV centenário tornou-se, assim, um evento privilegiado para a afirmação e louvação dos significados da paulistanidade diante da nação, sustentando a imagem de São Paulo, sobretudo no plano econômico, como modelo da nacionalidade. Paralelamente às evocações do passado, havia uma referência constante à prosperidade da cidade, visíveis em frases muito difundidas como "São Paulo: a cidade que mais cresce no mundo".

Como afirmou Lofego $^{72}$, a projeção do futuro vinha do passado, assim, esse precisava estar à altura das aspirações do presente. Era imprescindível, portanto, reelaborar a história da cidade, reestruturando seus alicerces. Desse modo, símbolos foram mobilizados e materializados a fim de resgatar o passado e criar uma identidade em que todos se sentissem pertencentes, que fosse capaz promover a coesão e atenuar contradições sociais, constituindo uma memória coletiva. As imagens veiculadas, os monumentos erigidos e os edifícios construídos deveriam servir de instrumento para difundir um discurso hegemônico, já que eram meios de demonstrar o que deveria ser lembrado e, pelas ausências que também expressavam, o que deveria ser esquecido.

A imprensa teve um papel de grande relevância na difusão dos símbolos do IV Centenário, pois os jornais tornaram-se porta-vozes preponderantes dos discursos que estavam sendo forjados. Uma grande quantidade de propagandas fazia referência à data comemorativa por meio de textos, fotografias, desenhos e músicas, que recuperavam os símbolos da identidade paulista, como o bandeirante, os jesuítas e os índios. Lofego aponta para grupos predominantes de mensagens, que variavam entre a utilização da "espiral"73 e do brasão da prefeitura de São Paulo, especialmente nas

\footnotetext{
7171 LOFEGO, Silvio Luiz. IV Centenário da Cidade de São Paulo: uma cidade entre o passado e o futuro. São Paulo: Annablume, 2004, p.26-28.

72 Idem, p. 29.

${ }^{73}$ A espiral, ou "aspiral", como afirma Lofego, foi o símbolo criado pelo Grupo Niemeyer de Arquitetura para representar a Comissão organizadora do evento. Além disso, ela deveria integrar o conjunto arquitetônico do parque lbirapuera, tornando-se um grande monumento na entrada principal do parque. Segundo Paulo César Garcez Marins, "tratava-se de uma forma helicoidal - uma espiral - que se arrancava abruptamente do solo apontando para o céu, simbolizando a pujança da cidade, do estado e do próprio país, do qual era a maior metrópole. Guardava do passado apenas o ponto de partida de sua escalada para o futuro, para o progresso". Ver, MARINS, Paulo César Garcez. O Parque do Ibirapuera e a
} 
propagandas oficiais do evento. Indica também os anúncios que estabeleciam uma relação direta com a tradição e memória paulista e as publicidades que se filiavam à ideia de modernização e progresso da cidade, mostrando edificações modernas ou produtos de última geração. Havia ainda propagandas que mesclavam esses imaginários sobre a metrópole ${ }^{74}$.

A despeito dos religiosos terem sido invariavelmente tomados como símbolo da fundação de São Paulo, eles foram completamente omitidos nos principais monumentos inaugurados durante o IV Centenário. Ednilson Quarenta ${ }^{75}$, que constatou esse descompasso, defende que a ausência de Anchieta e Nóbrega revela a existência de um campo de forças em um assunto que não era consensual. Dessa maneira, os monumentos realizados para a comemoração estaria em contraposição ao debate que movimentou a mídia e que disseminou a imagem dos jesuítas por toda parte. A questão identitária na cidade de São Paulo era, portanto, marcada por contradições.

É possível dizer que a polêmica em torno do mito fundador de São Paulo foi reanimada por meio das comemorações do IV centenário. Segundo Quarenta ${ }^{76}$, disputava-se a paternidade da fundação e as principais correntes envolvidas eram as que tomavam as figuras de José de Anchieta, Manuel da Nóbrega, João Ramalho, Tibiriçá ou todos os jesuítas indiscriminadamente. Uns defendiam que a instituição responsável pelo estabelecimento do São Paulo havia sido a Companhia de Jesus, que teria promovido o povoamento do planalto. Outros preferiam ressaltar as ações particulares de alguns missionários, dessa maneira, havia os que creditavam a Anchieta o papel de principal fundador, outros defendiam que seria Nóbrega, por ser ele quem havia rezado a missa e estabelecido o colégio. Existia também quem acreditasse que o esforço maior não havia partido dos religiosos, mas de Tibiriçá, chefe da nação indígena e braço construtor e defensor de Piratininga. Por fim, existiam os defensores de João Ramalho, português que havia vindo ao Brasil e permitido a conciliação entre indígenas e jesuítas. $O$ debate mais intenso, entretanto, recaiu entre os partidários de Nóbrega e Anchieta. A contenda envolveu diversos historiadores e culminou, inclusive, com o pronunciamento do Papa Pio XII. Serafim Leite

construção da identidade paulista. Anais do Museu Paulista: História e Cultura Material, São Paulo, , v. 6/7 (1998-1999). Editado em 2003, p.30-33.

74 LOFEGO, Silvio Luiz. IV Centenário da Cidade de São Paulo: uma cidade entre o passado e o futuro. São Paulo: Annablume, 2004, p. 112-114

75 QUARENTA, Ednilson. Apóstolo pregresso e as alegorias da fundação: Anchieta, um mito fundador no IV Centenário da Cidade de São Paulo. Tese (doutorado), Faculdade de Filsofia, Lestras e Ciências Humanas, Universidade de São Paulo, São Paulo, 2009, p. 35.

${ }^{76}$ Idem, p 184. 
argumentava que Nóbrega havia estado na região de Piratininga antes de janeiro de 1554, assim, quando Anchieta e outros religiosos aportaram no continente, o projeto da nova missão já estava prevista. Marcondes de Souza negou as declarações de Serafim Leite e, mesmo não defendendo que Anchieta seria o único fundador de São Paulo, afirmava que a participação do apóstolo na montagem do gesto fundador seria fundamental. Posição que era também sustentada pelo padre Hélio Abranches Viotti, defensor da causa anchietana.

O que Quarenta demonstra é que a imagem da fundação ficou cada vez mais circunscrita a Anchieta e Nóbrega, em contraposição a outros símbolos utilizados no passado. Tratava-se, afinal, de comemorar precisamente o que ocorrera em 25 de janeiro de 1554, evento no qual os protagonistas eram sem dúvida os inacianos fundadores da nova missão. A representatividade que o mito fundador deveria agregar transpunha os limites simbólicos cunhados em tempos anteriores, em que os bandeirantes eram tomados como protagonistas. Tendo em vista o perfil populacional da cidade de São Paulo, marcado pela heterogeneidade social e étnica, sobretudo pelo grande contingente de imigrantes, tornava o protagonismo bandeirante cada vez mais difícil de ser assimilado, por suas relações evidentes com as velhas elites "quatrocentonas"77. Já a herança católica não era questionada ou negada. Apesar do bandeirante, como demonstrou Esmeralda Moura ${ }^{78}$, continuar a ser empregado como símbolo do progresso de São Paulo e do trabalhador paulista na publicidade comemorativas do IV centenário que associou a glória e fascínio do passado com interesse do setor urbano-industrial, cada vez mais, a imagem do nascimento da cidade tornava-se indissociável da tradição cristã e, principalmente, da pessoa de Anchieta.

Quarenta afirma que as narrativas que difundiam a fundação de São Paulo como um trabalho em conjunto da Companhia de Jesus acabaram se diluindo em leituras constitutivas do mito fundador Anchieta, de forma que os outros religiosos que estariam envolvidos com a missão jesuítica em Piratininga no século XVI, incluindo Nóbrega, eram nomeados a partir do apóstolo que aparecia como o patriarca que

\footnotetext{
77 Paulo César Garcez Marins demonstra que o próprio presidente da comissão do IV Centenário, Francisco Matarazzo Sobrinho, conhecido como Ciccillo, evidencia a ascensão dos imigrantes ao universo simbólico comandado pelas elites dirigentes de São Paulo, ao mesmo tempo em que revela a diluição paulatina da proeminência de discursos ligados ao mito bandeirante. MARINS, Paulo César Garcez. O Parque do Ibirapuera e a construção da identidade paulista. Anais do Museu Paulista: História e Cultura Material,(São Paulo, v. 6/7 (1998-1999). Editado em 2003, p. 30.

${ }^{78}$ MOURA, Esmeralda Blanco Bolsonaro de. Bandeirantes do progresso: imagens do trabalho e do trabalhador na cidade em festa. São Paulo, 25 de janeiro de 1954. Revista Brasileira de História, São Paulo, v. 14, n. 28, p. 231-246, 1994.
} 
encabeçava a lista de fundadores. Em sentido inverso, as argumentações que endossaram o nome de Nóbrega como fundador não permitiam a inclusão de outros interlocutores, constituindo uma interpretação mais sectária, que defendia a tese da unicidade e exclusividade do religioso na fundação ${ }^{79}$.

Como os atos comemorativos que ocorreram no IV Centenário de São Paulo tiveram a conotação de integração, a imagem de Anchieta, espanhol de origem, constituiu-se, aos poucos, na mais estratégica, na medida em que a sua narrativa tinha um forte apelo agregador, contribuindo para atenuar as discrepâncias e dissensões. O mito anchietano unia múltiplos sentidos, mediando uma difícil conciliação, por isso, ampliava o seu campo de representação. Nas palavras de Quarenta, a visão menos fechada em torno de Anchieta abarcava, naquele contexto social, outros artífices, em uma cidade de muitas nacionalidades, de várias culturas e, por que não, de vários fundadores ${ }^{80}$.

A guinada do tema da fundação para o viés religioso ficou nítido também com a valorização do Pátio do Colégio, cujo sentido como símbolo da fundação havia estado, por décadas, obscurecido. Animados pelo ânimo de revitalização da arquitetura colonial de São Paulo, a partir dos anos 1940, surgem propostas para a reconstrução do conjunto jesuítico do Pátio do Colégio, cujos restos muito alterados estavam, naquele momento, ocupados pela Secretaria de Educação. Uma dessas iniciativas, indicada por Lima, partiu de José Mariano Filho, que exaltava o passado colonial e pregava a reconstituição da igreja como forma de criar o elo necessário entre a origem e o futuro ${ }^{81}$. Ademais, não havia mais o antagonismo entre Clero e Estado que marcara os primeiros anos da República e, portanto, eles podiam unir-se em prol da fundação da cidade, concentrando a carga simbólica do mito de origem em José de Anchieta.

A partir de 1945, foi entregue ao interventor de São Paulo, Fernando Costa, um livro que continha 4000 assinaturas solicitando o reestabelecimento do colégio. Lima afirma que este documento ficou perdido em arquivos governamentais até 1953. A partir de então, foi encaminhado para aprovação na Assembleia Estadual um projeto que, segundo Quarenta, teve seus trâmites acelerados devido às proximidades com as comemorações do IV Centenário. Dessa maneira, em 21 de janeiro de 1954 foi

\footnotetext{
${ }_{79}$ QUARENTA, Ednilson. Apóstolo pregresso e as alegorias da fundação: Anchieta, um mito fundador no IV Centenário da Cidade de São Paulo. Tese (doutorado), Faculdade de Filsofia, Lestras e Ciências Humanas, Universidade de São Paulo, São Paulo, 2009, p 194-195.

80 Idem, p 204.

${ }^{81}$ LIMA, Solange Ferraz de. Pátio do Colégio, Largo do Palácio. Anais do Museu Paulista, (São Paulo). Nova série, v. 6/7 (1998-1999). Editado em 2003, p.72.
} 
assinada uma lei pelo governador Lucas Nogueira Garcez, que devolvia à Companhia de Jesus o terreno do Pátio do Colégio, como foi noticiado pelo jornal $O$ Estado de São Paulo:

Tendo sido promulgada no dia 21 do corrente e publicada no "Diário Oficial"de 22, a lei n. 2.658, que dispõe sobre a doação de imóveis, nesta Capital, à Companhia de Jesus, ficou a Sociedade Brasileira de Educação, com sede no Distrito Federal e mantenedora das "Obras Sociais, Catequéticas e Educacionais" da mesma Companhia obrigada a providenciar a construção, no Pátio do Colégio, de uma igreja e uma escola que funcionem cursos noturnos para a juventude que trabalha, além da "Casa de Anchieta", destinada ao museu colonial para conservação e exibição das relíquias históricas e ao culto dos fundadores da cidade ${ }^{82}$.

É possível perceber, portanto, que a Igreja Católica, na década de 1950, retomou o lugar de destaque na fundação de São Paulo. A narrativa apresentava a cidade como constituída, desde a sua origem, como uma urbe predestinada ao cristianismo e preparada para sacramentar um percurso histórico que agregou todos os espaços necessários e estratégicos edificados em símbolos da fundação, como o colégio, a vila e a capela ${ }^{83}$. Como se fosse um legado providencial, o percurso histórico de São Paulo é imbricado com a tradição cristã, que segue um caminho lógico e natural em direção ao progresso. Nesse ínterim, Anchieta emergia como figura capaz de unificar diversas posições, abolindo diferenças e ocultando contradições.

Nessa nova proposta de leitura histórica, a tela de Oscar Pereira da Silva encontrava possibilidade de desempenhar um papel privilegiado, já que continha uma imagem sobre o ato inicial de São Paulo, em convergência à interpretação de muitos historiadores, políticos e grande parte da mídia em torno de 1954. Ambientada no lugar em que posteriormente se configuraria o Pátio do Colégio, a tela colocava como ponto central os jesuítas, sem se concentrar em uma única figura, mas apresentando os diversos missionários que estiveram presentes naquele 25 de janeiro de 1554 . Não era Anchieta quem rezava a missa, porém, ele estava presente naquele ato oficial. $A$ presença de outros personagens que haviam sido pleiteados para ocupar a posição do patriarca por excelência de São Paulo também estavam inseridos na representação: Tibiriçá e João Ramalho. A imagem, portanto, conciliava diversos discursos.

\footnotetext{
82 O Estado de São Paulo, 25 de janeiro de 1954, p. 155.

83 QUARENTA, Ednilson. Apóstolo pregresso e as alegorias da fundação: Anchieta, um mito fundador no IV Centenário da Cidade de São Paulo. Tese (doutorado), Faculdade de Filsofia, Lestras e Ciências Humanas, Universidade de São Paulo, São Paulo, 2009, , p. 41.
} 
Pode-se inferir que, por conta desse conjunto de fatores, a imagem Fundação de São Paulo, de Oscar Pereira da Silva foi intensamente utilizada durante esse período, em diferentes suportes relacionados às comemorações. Esteve, por exemplo, presente com ênfase nos periódicos, em anúncios, edições comemorativas e reportagens, que contribuíam amplamente para a construção de uma memória social.

Segundo Esmeralda Moura, ao observar a cobertura jornalística do IV centenário é possível perceber o poder de sedução que o evento conseguiu exercer na população. O espaço publicitário tornou-se um canal político oportuno e adequado às determinações capitalistas. A publicidade projetava uma imagem da cidade que era complexa e multifacetada, como metrópole pujante na lavoura, extraordinária na indústria e envolvente no comércio. A cidade ganhou uma personalidade que pretendia reverter a velha ordem agrária pela industrialização, pela imagem progressista, de franco e acelerado crescimento. A chaminé e a fumaça se tornaram símbolos do desenvolvimento econômico e a cidade foi concebida como sinônimo de progresso. Para conferir maior eficácia à simbologia, a memória foi acionada, revestindo as mensagens de historicidade ${ }^{84}$.

A propaganda da Esso (figura 1), por exemplo, coloca a imagem do antigo edifício da Igreja do Pátio do colégio em meio aos novos arranha-céus, que se tornavam característicos da metrópole paulista. O passado legitima o presente, como está nítido nos dizeres "nascida em torno de um Colégio, São Paulo cresceu e se tornou metrópole sob o signo da Cultura. 400 anos após, o pequeno Colégio transformou-se nessa imensa escola do civismo e trabalho que é a trepidante São Paulo de hoje, com seus dois milhões e meio de habitantes" ${ }^{\prime 5}$. A propaganda do Vermouth Cinzano (figura 2) é outro exemplo de associação entre passado e presente. Em uma das taças é possível ver a imagem de São Paulo em 1554, com a rústica igreja feita de madeira, na taça que representa o momento contemporâneo, mostra-se uma cidade moderna e repleta e edificações.

\footnotetext{
${ }^{84}$ MOURA, Esmeralda Blanco B. de. Bandeirantes do progresso: imagens do trabalho e do trabalhador na cidade em festa. São Paulo, 25 de janeiro de 1954. Revista Brasileira de História, São Paulo, v. 14, n. 28, p. 231-246, 1994, p. 235-241.

${ }^{85}$ Folha da Manhã, 24 e 25 de janeiro de 1954.
} 


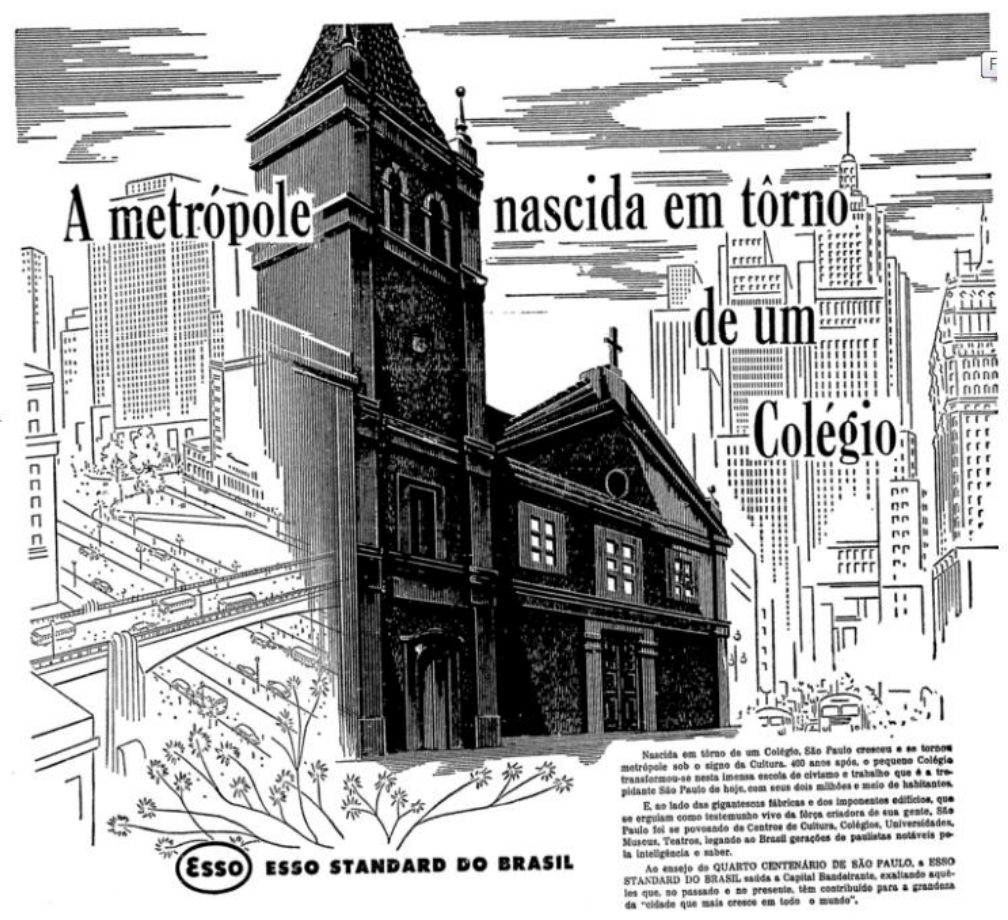

Figura 5 - Propaganda Esso, Folha da Manhã de 24 e 25 de janeiro de 1954.

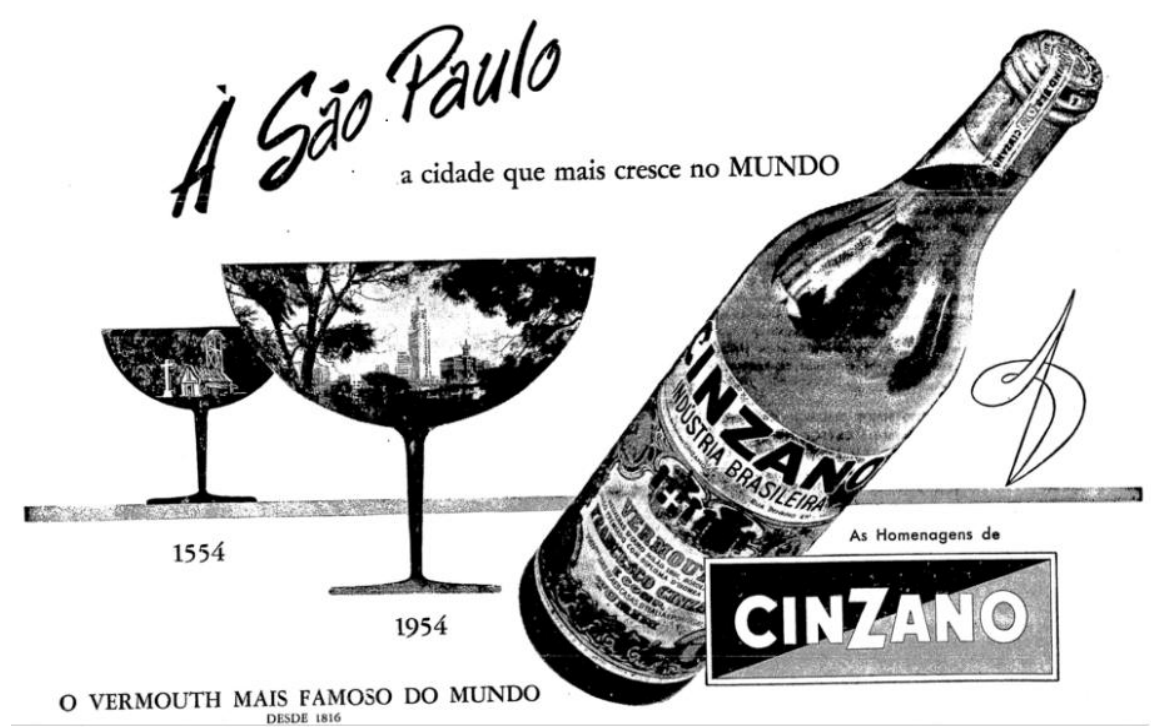

Figura 6 - Propaganda Vermouth Cinzano, Folha da Manhã, 24 e 25 de janeiro de 1954.

É nesse esforço de associação entre passado e presente que a imagem da Fundação de São Paulo serviu de referência a algumas propagandas, como a da empresa de relógio Hora (figura 3), que trouxe o núcleo central do quadro de Oscar Pereira da Silva, mas inseriu um índio em primeiro plano que é diferente dos que aparecem na representação pictórica, mas semelhante ao leitor que, como ele, 
contempla a cena. Os dizeres que a acompanham destacam o vaticínio que a fundação lançara:

Olhemos o passado, aquela hora que assinalou a fundação de São Paulo, o instante maravilhoso em que bugres empenachados espiavam curiosos a celebração da primeira missa no planalto. Hoje, transcorridos quatrocentos anos, podemos ajuizar exatamente a significação desse fato. É uma lição que nos ensina que não devemos perder tempo... Que cada um de nós tem sua parcela de responsabilidade quanto ao futuro de São Paulo. O segredo do extraordinário progresso de nossa terra não tem sido outro que o trabalho com todas as suas imposições: pontualidade, divisão e aproveitamento máximo do tempo. Prosseguir, pois, nesse mesmo critério, é contribuir decisivamente para a maior grandeza de São Paulo, grandeza para a qual a Empresa Brasileira de Relógios "Hora" S.A. julga vir contribuindo também - e tem nisto o seu melhor galardão ${ }^{86}$.

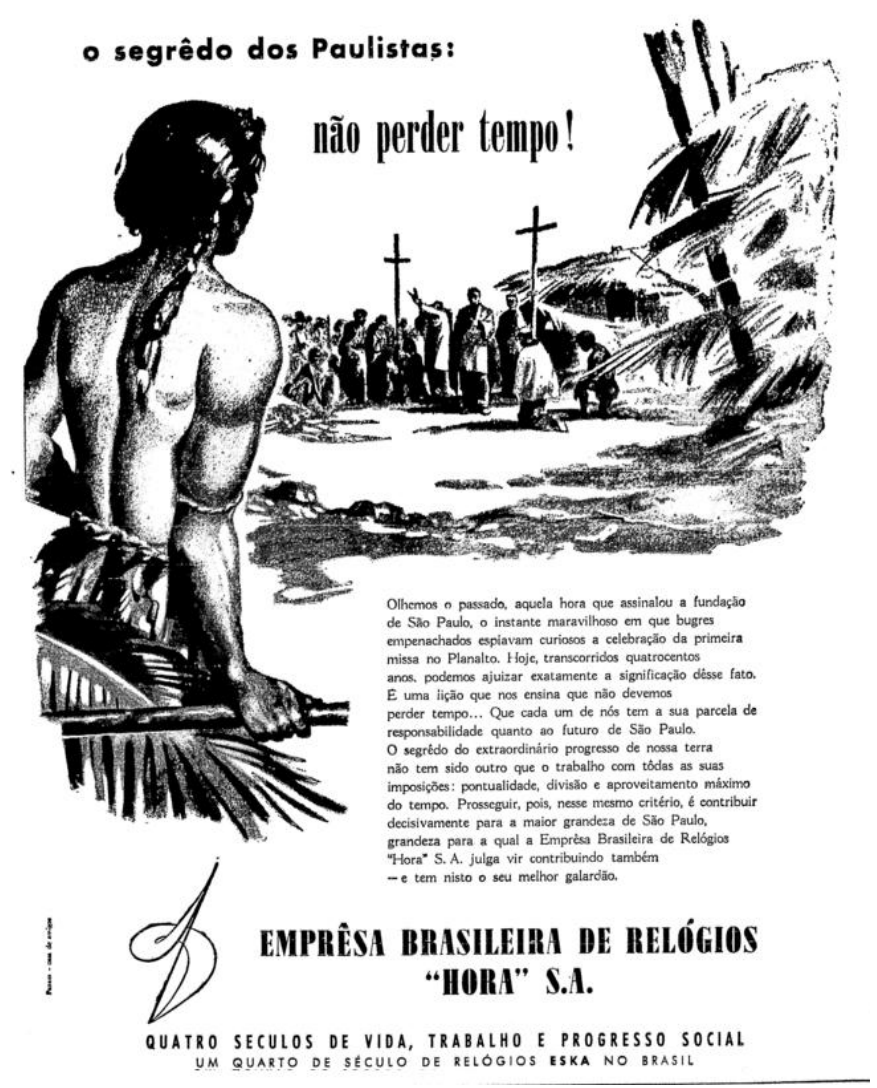

Figura 7 - Propaganda da emprese de relógio Hora S.A., Folha da manhã, 24 e 25 de janeiro de 1954.

\footnotetext{
${ }^{86}$ Propaganda da empresa "Hora" S.A. difundida no Folha da Manhã, 26 de janeiro de 1954.
} 


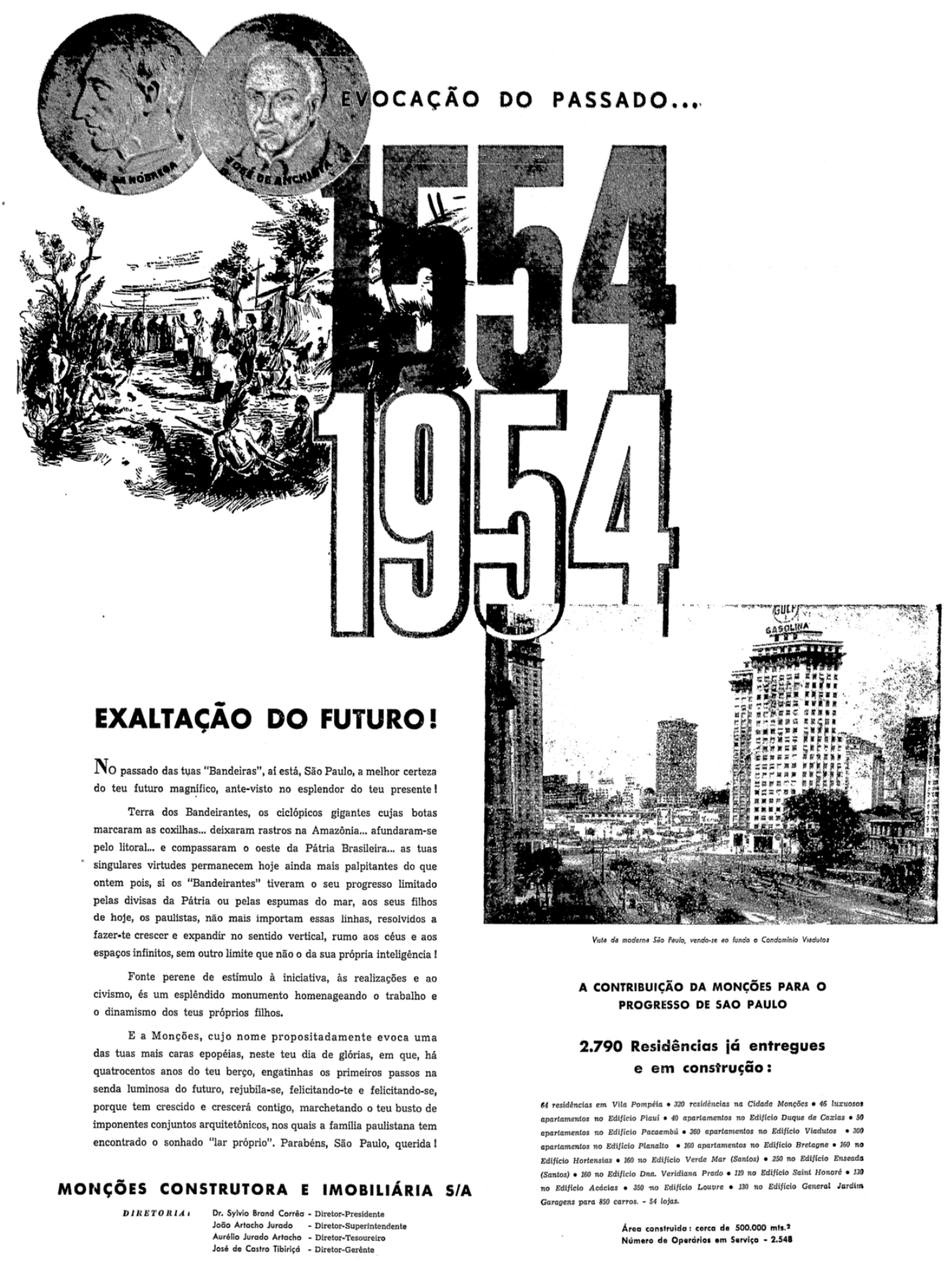

FOLHA DA MANHÃ, DOMNGO E SEGUNDA-FERA, 24 E 25 DE JANEiRO DE 1954 - ATUALLDADES E COMENTARIOS - $\|$ - Pag. 5

Figura 8 - Propaganda Monções construtora e Imobiliária S/A, Folha da manhã, 24 e 25 de janeiro de 1954.

A associação entre passado, presente e futuro é evidente. Olhar para o que passou tornava-se, no dizer do anúncio, "uma lição", que explicava o segredo de São Paulo obter "extraordinário progresso", baseado na ciosa economia de tempo. Essas associações ufanistas, e por vezes evidentemente forçadas, entre o presente da 
cidade e a ação dos jesuítas estão presentes também na propaganda da Monções Construtora e Imobiliária S/A (figura 4). O anúncio apresenta uma composição que contém a cena central do quadro de Oscar Pereira da Silva, os retratos de Anchieta e Nóbrega e uma foto da "São Paulo moderna", e anunciava: Evocação do passado... exaltação do futuro!

No texto da propaganda, entretanto, não há nenhuma menção aos missionários, já que destacava, apenas, a ação dos Bandeirantes. Ele iniciava dizendo: no passado das tuas "Bandeiras", aí está, São Paulo, a melhor certeza do teu futuro magnífico, ante-visto no esplendor do teu presente! Assim, partia da imagem dos fundadores, passava pelos feitos dos bandeirantes, dizendo estes haviam sido limitados pelas divisas da Pátria ou pelas espumas do mar. Para, enfim, chegar aos paulistas, filhos dos bandeirantes, a quem não importavam essas linhas limitadoras, pois o sentido da expansão, naquele momento, era vertical: rumo aos céus e aos espaços infinitos, sem outro limite que não o da própria inteligência!

Com essa propaganda, é possível notar o que afirmou Quarenta, ao dizer que o mito bandeirante não poderia abarcar sozinho toda a reconciliação com o passado. Por isso, precisou recorrer, além dos "verdadeiros" paulistas oriundos da "raça" portuguesa, a outros importantes personagens do passado Piratininga. Assim, a imagem do índio, por exemplo, passava a ser muito recorrente, como símbolo da superação da natureza e das hostilidades do litoral. Portanto, a tela de Oscar Pereira da Silva era muito oportuna, pois unia, harmoniosamente, todos os possíveis mitos quinhentistas em uma única cena.

Outra propaganda que se remete à cena criada por Oscar Pereira da Silva, embora bastante relida, é a da Semp Rádio e Televisão S.A. (figura 5), que deu contornos mais modernos à imagem, mas utilizou a mesma ação que há no quadro - o ato da bênção - e a mesma postura dos personagens centrais, o que torna a associação muito evidente. No texto, a fé e a religião são mobilizadas para justificar e legitimar o crescimento da cidade e o bom resultado da miscigenação que deu origem ao paulista:

As comemorações que engalanam São Paulo na passagem do seu IV Centenário de fundação, significam também um ato de Fé. A própria São Paulo, desde o seu primeiro momento foi um propósito de Fé. Fé no templo-escola-oficina que então se erguia, Fé na mescla de três raças que fundamentaram uma civilização tropical, Fé no amanhã da terra e do povo, que como uma espiral ascendente rumo ao futuro assinala a entrada do porvir $p^{\beta 7}$

\footnotetext{
${ }^{87}$ Propaganda SEMP rádio e televisão S.A., O Estado de São Paulo, 25 de janeiro de 1954.
} 


\section{DE JANEIRO \\ DE 1954}

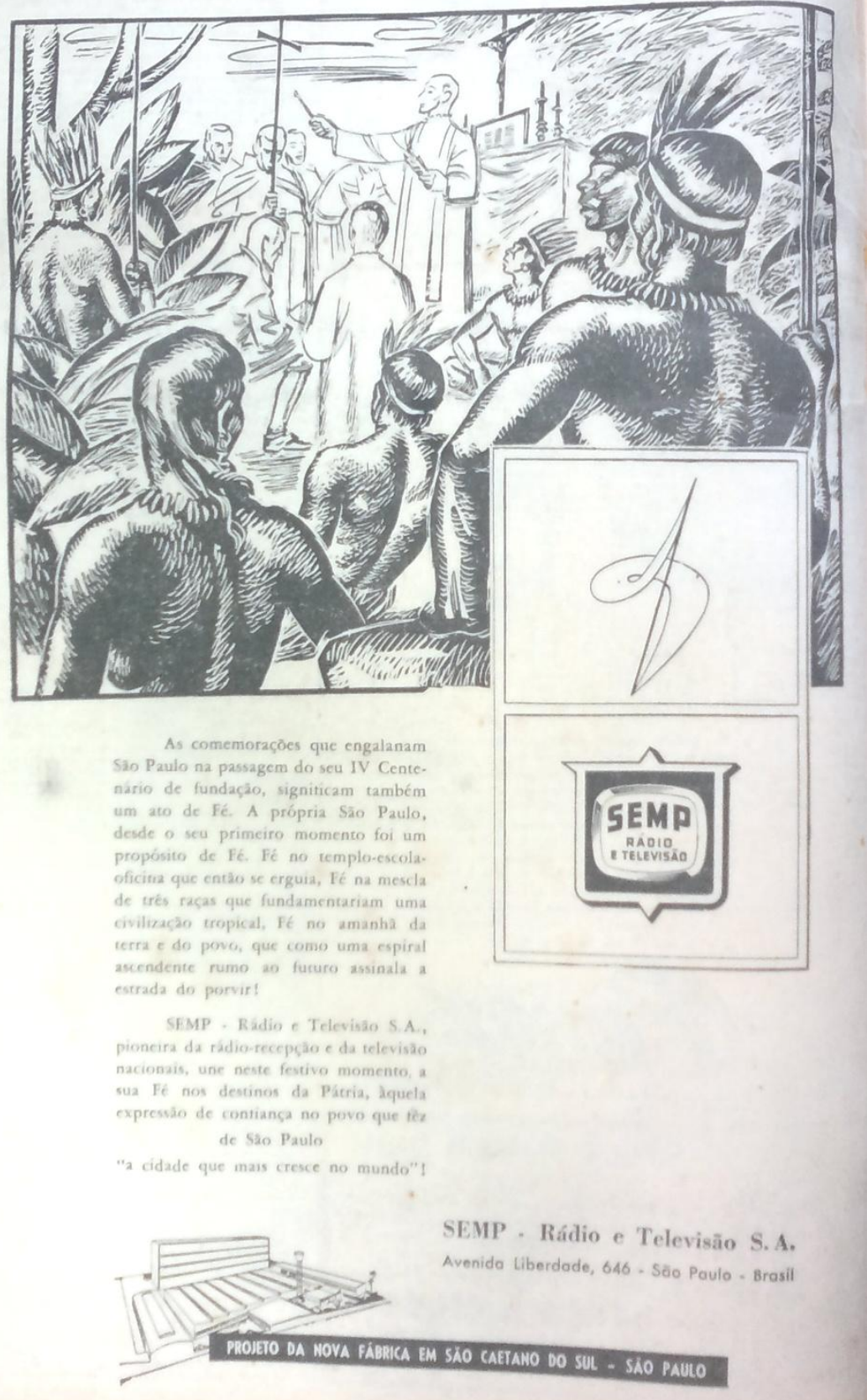

Figura 9 - Propaganda Semp Rádio e Televisão S.A., O Estado de São Paulo, 25 de janeiro de 1954.

Além das propagandas nos jornais, a imagem da tela de Oscar Pereira da Silva foi utilizada em reportagens e artigos comemorativos à aclamada data, como aconteceu, por exemplo, em 30 de janeiro de 1954, no Correio Paulistano, e também no O Estado de São Paulo do dia 25 de janeiro de 1954. Mas, não foram só os materiais impressos que se utilizaram da grande obra para comemorar o IV 
Centenário, outros suportes também fizeram uso dela divulgando-a e tornando-a conhecida. Em alguns casos, a referência é sutil, como o prato de porcelana comemorativo do IV centenário (figura 6), que tem a reprodução parcial do quadro, já que parte da cena está encoberta pela figura de José de Anchieta. Na borda da porcelana há imagens de edifícios significativos para a história de São Paulo, como o Pátio do colégio, a antiga Sé, o paço municipal e, encabeçando o conjunto, está o brasão da cidade. Em outros casos, a referência é mais direta, como na bandeja ${ }^{88}$ feita pela empresa Metalma, que reproduziu o quadro em seu fundo.

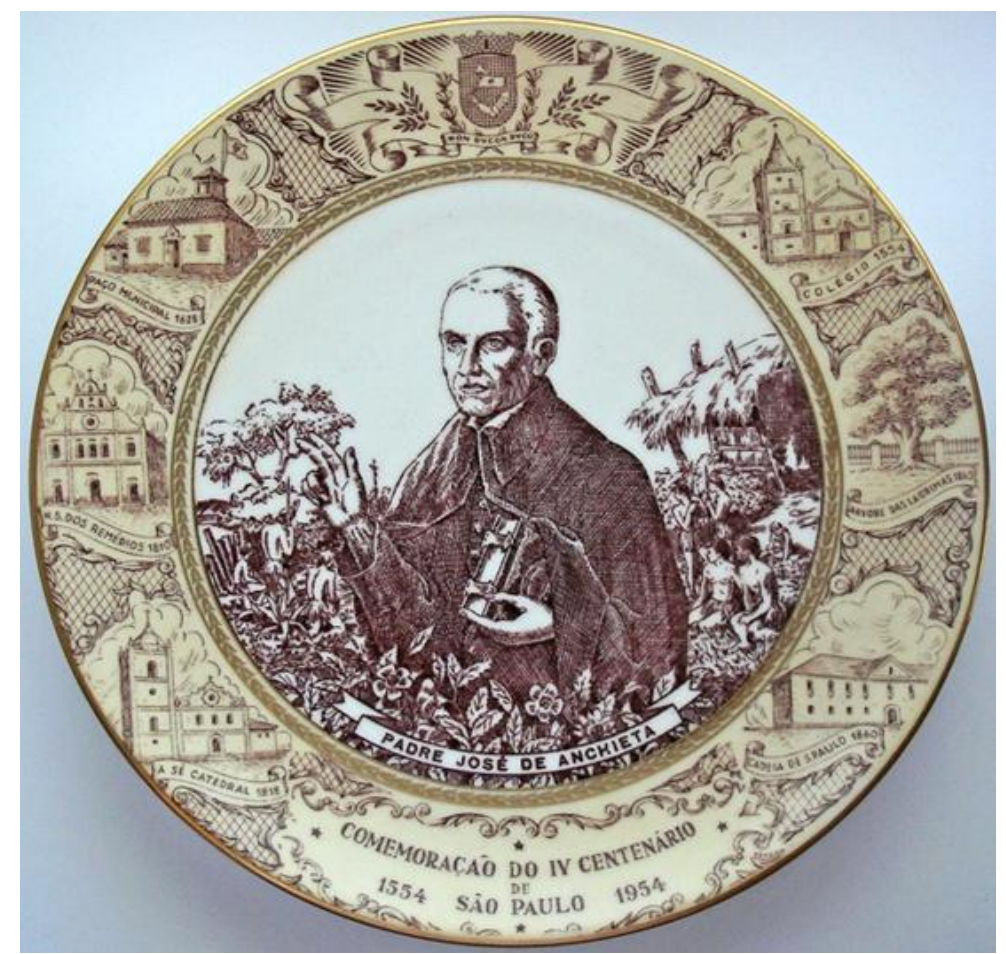

Figura 10 - Prato comemorativo do $4^{\circ}$ centenário da cidade de São Paulo, Mauá, Porcelana Mauá S/A, 27 cm de diâmetro, acervo do Museu Paulista da USP

É possível dizer, portanto, que 1954 foi uma ano chave para que o quadro de Oscar Pereira da Silva se configurasse no imaginário social como a cena da origem de São Paulo. Apesar de tanta evidência da tela Fundação de São Paulo nas comemorações do IV Centenário, e de seu papel na difusão de uma certa interpretação das conexões entre passado e presente da cidade, ela permaneceu longe dos olhos do público. Em 1954, o Museu Paulista passou todo o ano fechado para reformas, o que levou a instituição a emprestar parte de seu acervo para a exposição histórica que ocorreu no Parque Ibirapuera. A tela de Oscar Pereira da

${ }^{88}$ Bandeja comemorativa do IV centenário de São Paulo, lata $33 \times 45 \times 2 \mathrm{~cm}$, Metalma, 1954, acervo do Museu Paulista da USP. 
Silva, entretanto, não configurou entre as obras cedidas. Um motivo para essa ausência pode ter sido o fato de, nesse mesmo ano, o quadro ter passado por um processo de restauro, como é possível observar no relatório anual da instituição:

Várias telas passaram por restauração, dado os furos e arranhaduras como as remoções de tinta e retoques necessários, tendo sido os trabalhos executados de acordo com a técnica do caso. As telas são as seguintes: Fundação de São Paulo, Ciclo do Índio, Ciclo dos Criadores de Gado, Ciclo do Ouro, Retirada do Cabo São Roque, D. João VI, D. Pedro II, N. Sra. da Conceição ${ }^{89}$.

Sem a sua participação na exposição e com o Museu Paulista fechado, o acesso ao quadro de Oscar Pereira da Silva decididamente esteve comprometido. Isso não impediu que cumprisse um papel decisivo nas representações divulgadas durante as comemorações do aniversário da cidade, apenas por meio de reproduções. Outras obras e outros símbolos poderiam, todavia, ter sido mobilizados nessa campanha, porém, a escolha recaiu sobre a Fundação de São Paulo, que, como se viu, encaixava-se num redirecionamento das interpretações históricas em que os jesuítas e a síntese católica ganhavam força e contemporaneidade.

Ainda que a Fundação de São Paulo fosse incômoda aos olhos de Taunay quando de sua transferência, motivo pelo qual jamais foi integrada ao cerne discursivo da exposição sobre a história paulista e nacional, o transcurso do tempo renovou e notabilizou sua apropriação social. A entrada do quadro no Museu Paulista em 1929 foi fundamental na sua trajetória, pois ali ganhou estatuto de documento histórico, permanecendo duas décadas exposta ao público. Mesmo que a chegada no Ipiranga não tenha ocorrido de maneira triunfal, sendo pouco divulgada pela mídia e omitida dos relatórios do museu, a sua inserção na instituição museológica foi certamente o que permitiu sua retomada na década de 1950 como visão da origem de São Paulo e explicação de sua grandeza no presente.

\footnotetext{
${ }^{89}$ Relatório Anual do Museu Paulista, 1954, p.3, grifo meu.
} 


\section{CONSIDERAÇÕES FINAIS}

A proposta dessa dissertação é debruçar-se sobre uma obra e, percorrendo e reconstruindo sua trajetória, observar a sociedade em que estava inserida. Esse percurso permitiu perceber como a Fundação de São Paulo foi produto de sua época, portanto, documento para entender o contexto que a produziu. $O$ mais significativo, entretanto, foi analisar a obra enquanto vetor de significados, pois ela mediou práticas sociais, veiculou interpretações do passado e discursos, sendo percebida contrastivamente ao longo do século XX.

A consagração da tela não foi um processo isento de tensões. Ao longo de sua trajetória social, a tela atravessou muitos impasses e obstáculos, advindos das múltiplas percepções em relação ao que seu conteúdo imagético afirmava. A partir de sua musealização, a Fundação de São Paulo desempenhou um papel decisivo no imaginário social coletivo relativo à história da cidade de São Paulo e à própria experiência do contato, tal como postula Baczko ${ }^{90}$, servindo de orientação da atividade imaginativa em direção ao social, na medida em que veiculava a representação da ordem social do evento de origem de São Paulo, dos atores que estavam envolvidos nesse processo e de suas relações recíprocas. Tornou-se referência simbólica, capaz de demonstrar e definir os indivíduos que pertenciam àquela sociedade, além de servir para produção e legitimação de projeções e sonhos para o futuro ${ }^{91}$.

Como demonstra Baczko, cada época tem sua modalidade de imaginar, reproduzir e renovar o imaginário, pois possui meios específicos de acreditar, pensar e sentir. Essas transformações foram percebidas no próprio percurso da obra, já que a sua apropriação variou de acordo com a conjuntura em que estava inserida. Assim, diante do contexto de rememoração do tempo da fundação de São Paulo, em 1954, momento em que já havia se dispersado o antagonismo entre Estado e Clero, o quadro de Oscar Pereira da Silva se configurou como objeto privilegiado para a representação do passado remoto. Constituiu-se como lugar de memória da origem de São Paulo, já que congregou os três sentidos propostos por Pierre Nora ${ }^{92}$ : material, ou seja, deu substrato físico ao ato de origem, criando a imagem do evento que fosse tangível; simbólico, pois conseguiu reunir harmoniosamente as necessidades dos

\footnotetext{
90 BACZKO, Bronislaw. Imaginário social. In ROMANO, Ruggiero (org.). Enciclopédia Einaudi, volume5: Anthropos-Homem . Lisboa: Imprensa Nacional; Casa da Moeda, 1985, p. 296-332.

91 Idem, p. 309-312

92 NORA, Pierre. Entre Memória e História: a problemática dos lugares. Revista Projeto História ,São Paulo, no 10, 1993
} 
diversos setores sociais que estavam à frente da construção da memória histórica paulista; e funcional, já que foi efetivamente apropriado pela coletividade e, por isso, foi reproduzido intensamente como representação da origem de São Paulo, muitas vezes até tomado como documento contemporâneo ao evento nela retratado.

O papel de rememoração que a tela desempenhava nas primeiras décadas do século $X X$ era reforçado pelo fato do Pátio do Colégio, naquele período, não representar mais simbolicamente o espaço de memória da fundação de São Paulo. Porém, essa situação alterou-se, uma vez que a mobilização de setores da sociedade em prol da reconstrução das antigas edificações, que havia começado em 1945, culminou, em 1953, com a demolição do Palácio do Governo a descoberta dos vestígios da construção de taipa precedente. A Igreja coordenou a "Campanha da Gratidão", que tinha como objetivo reunir verbas para as reconstruções e, assim, em 1956, as obras tiveram início. Pretendia-se reverter o esquecimento do caráter sagrado daquele local, trazendo à tona a lembrança do período colonial, transformando-o em lugar de memória da fundação de São Paulo, mesmo que para isso fosse necessário construir novos edifícios representantes dos antigos, como demonstra Solange Lima:

A recriação do passado a partir de um idealizado momento fundante, eliminando os traços materiais do processo de uso desse mesmo espaço nos últimos 130 anos, sugere uma ação apaziguadora, compensatória da espoliação das práticas que culminou no esvaziamento de sentido de um espaço secular ${ }^{93}$.

As obras foram finalizadas, na década de 1970, pela Sociedade Brasileira de Educação, instituição brasileira ligada à ordem dos jesuítas. A reconstrução da Igreja certamente contribuiu para que a tela de Oscar Pereira da Silva perdesse parte de sua força simbólica, visto que a recristianização do espaço e a restauração dos jesuítas fez com que o próprio pátio fosse o símbolo privilegiado da fundação e da síntese católica.

A tela permanece, contudo, em pleno processo de musealização, não mais como "janela para o passado" mas como monumento a que se quer dar um renovado estatuto de documento histórico. Esta dissertação, sem esgotar as possibilidades de compreensão dos processos de sua contínua apropriação - a exemplo nas dezenas de publicações didáticas que a tomam como representação fiel da fundação da cidade

\footnotetext{
${ }^{93}$ LIMA, Solange Ferraz de. Pátio do Colégio, Largo do Palácio. Anais do Museu Paulista: História e Cultura Material, São Paulo, v. 6/7 (1998-1999). Editado em 2003, p 78.
} 
e não como obra de arte realizada no início do século $X X^{94}$ - pretendeu colaborar em meio aos estudos acadêmicos que problematizam a pintura histórica como um dos mais significativos suportes de construção simbólica no país.

\footnotetext{
${ }^{94}$ Muitos materiais didáticos recorreram à Fundação de São Paulo para "ilustrar" os capítulos sobre a colonização do Brasil, tais como: SILVA, Joaquim. História do Brasil, São Paulo, Companhia Editora Nacional, 1958;CASTRO, Julierme de Abreu e. História para a escola moderna história do Brasil. São Paulo: IBEP, 1971; CARVALHO, L. G. Motta. Ensino moderno de história do Brasil. São Paulo: Editora do Brasil S.A., 1975; LUCCI, Elian Alabi. História do Brasil - TDHB 5. São Paulo: Editora Saraiva, 1975. Ilustrações: Eugênio Colonnesi, cujos exemplares consultados pertencem aoacervo da biblioteca da Faculdade de Educação da Universidade de São Paulo (FE-USP).
} 


\section{FORTUNA CRÍTICA DA OBRA}

1.

O pintor Oscar Pereira da Silva trabalha atualmente num quadro histórico e que se inspira no passado paulista.

Para o respectivo esboço o distinto artista tem procurado investigar antiguidades e tradições coloniais.

Desejando obter conhecimentos mais aprofundados, Oscar Pereira da Silva tem procurado arquivos, esteve no Museu do Estado e ainda ontem consultou várias obras na biblioteca da Escola Normal.

- QUADRO histórico, Registro de Arte, Correio Paulistano, 22 de janeiro de 1907

\section{2.}

Esteve ontem em palácio, onde foi convidar o sr. Presidente do Estado para visitar a exposição de pintura que brevemente inaugurará no salão nobre do "Progredior" o pintor Oscar Pereira da Silva.

Artes e Artistas, O Estado de São Paulo, 12 de dezembro de 1907

3.

Hoje, às 11 horas da manhã no "Salão Progredior", realiza-se a inauguração da grande tela do pintor Oscar Pereira da Silva o "Batismo de São Paulo".

Recebemos um convite para esse ato

Artes e Artistas, O Estado de São Paulo, 14 de dezembro de 1907

4.

O distinto pintor sr. Oscar Pereira da Silva inaugurou ontem a exposição de sua grande tela - "A Fundação de S. Paulo". 
O assunto é digno de ser tratado nas proporções que o artista deu ao se quadro, e desde já diremos que este se afigura o melhor trabalho do sr. Oscar Pereira da Silva, cujos recursos de técnica são grandes e que não encontra quem o supere, no nosso meio artístico, na exatidão de seu desenho vigoroso e na justeza do colorido, sempre sóbrio e isento de preferências mórbidas que a fotografia Lumiére veio pôr a descoberto, confirmando as opiniões de observadores de visão normal.

Hoje falta-nos espaço para uma mais larga apreciação. Limitamo-nos, por isso, a noticiar esse fato auspicioso para o nosso pobre meio artístico, e recomendar aos amadores o notável trabalho do sr. Oscar Pereira da Silva

OSCAR Pereira da Silva, Artes e Artistas, O Estado de São Paulo, 15 de dezembro de 1907

5.

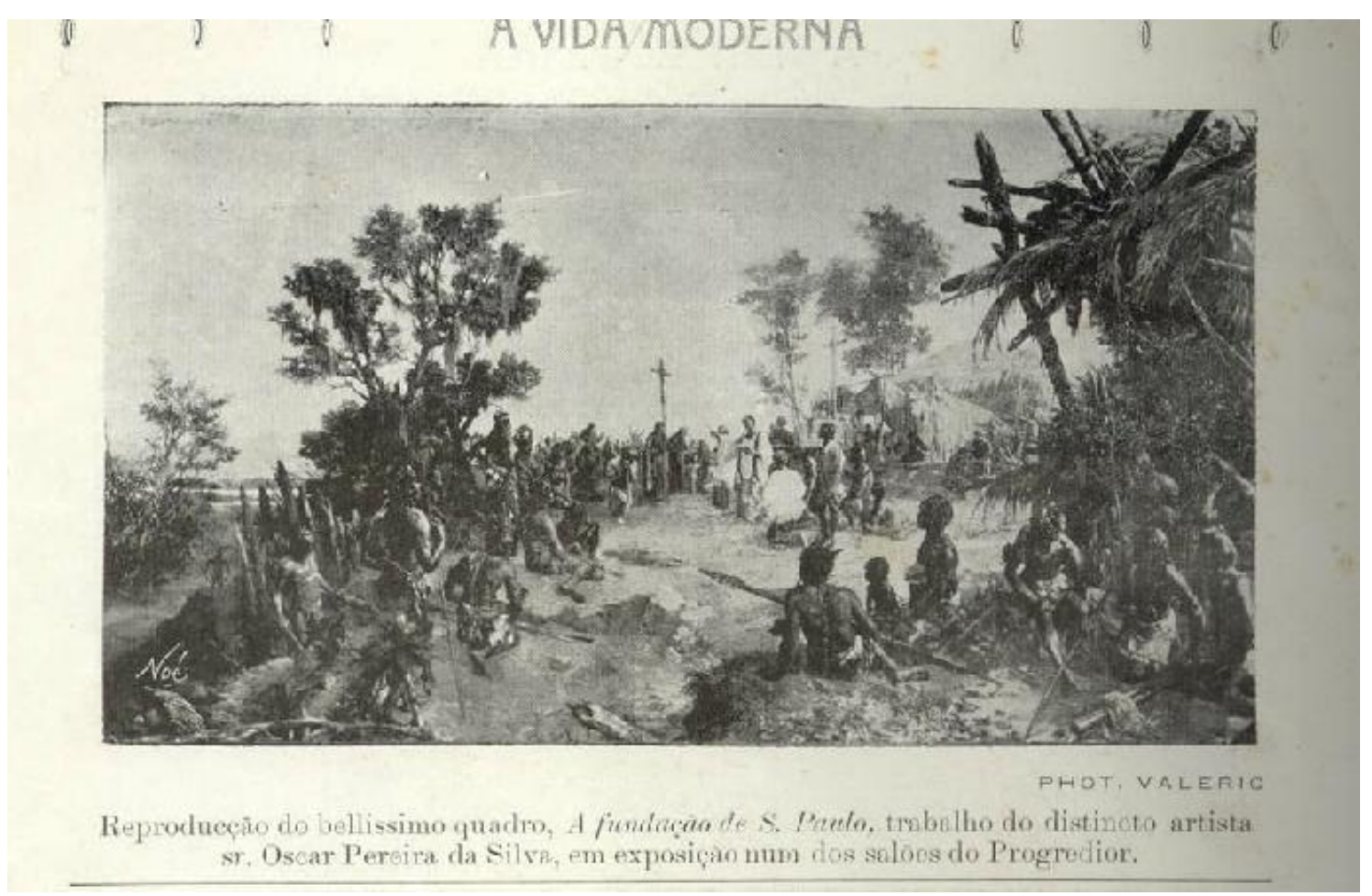

Reprodução do belíssimo quadro, $A$ fundação de $S$. Paulo, trabalho do distinto artista sr. Oscar Pereira da Silva, em exposição num dos salões do Progredior.

- A vida moderna, 25 de dezembro de 1907

6. 
Encerra-se hoje no salão do "Progredior", a exposição de quadros de Oscar Pereira da Silva.

Os que ainda ali não foram admirar os trabalhos do bizarro artista, não devem perder o dia de hoje, o último em que lhes será facultada a ocasião poderem admirar vários quadros de um alto valor artístico e dentre os quais se destaca pela concepção, verdade histórica e, sobretudo, esmero de execução, a grande tela denominada "Fundação de S. Paulo".

Ai está um quadro digno de figurar no Museu do Estado. Há nele tudo quanto se pode exigir em arte: inspiração, desenho, técnica, todas as qualidades indispensáveis a um pincel que se propõe a reproduzir na tela um acontecimento histórico, tendo em vista os testemunhos da época, a importância do fato e a intensidade histórica que o mesmo the deve merecer.

$\mathrm{Na}$ "Fundação de S. Paulo" não se sabe que mais admirar, se o estudo da natureza, tão vitorioso de compreensão no verdejante plano dos campos de Piratininga entre os rios Tamanduateí e Anhangabaú, se o estudo das figuras, que a luz e atmosfera põem em relevo, proporcionando ao visitante todos os meios de admirar o escrúpulo; o carinho e o "savoir faire" com que Oscar Pereira da Silva as desenhou, vestiu e tornou, vívidas.

Nos outros quadros, e não são poucos, há, tratados com um espírito de arte verdadeiramente sóbria, assuntos diversíssimos. É prova do que afirmamos o de n. 1 (Interior de cozinha), quadro de gênero, em que a luz tanto é viva é real na figura como nos apetrechos domésticos que lhe servem de acessório. Os nossos olhos são atraídos para esse quadro pela forte impressão do desenho, que é corretíssimamente executado.

Depois, se passamos à praia de Itaré, ou uma paisagem, uma cabeça, uma natureza morta, é sempre o mesmo prazer espiritual de visão abrangendo nas suas investigações de analise esses riquíssimos efeitos de luz, do traço, de sentimento.

Mas, não sabemos porque, os nossos olhos buscam de novo a grande tela. É natural. É o maior quadro do certame, pelas proporções, pela importância do assunto, pela execução.

Que o saibamos, ninguém até agora se atreveu a tratar da fundação de São Paulo do modo por que o fez o pincel de Oscar. 
Quem leu no padre Simão de Vasconcelos as páginas referentes ao trabalho de Anchieta, Manuel de Paiva e Manuel Nóbrega, parece vir encontrar na tela de Oscar pereira da Silva a expressão eloqüente e vívida do episódio da fundação de S. Paulo. Um quadro como este é digno de todo elogio e tem absoluto direito de ocupar um lugar de honra entre as telas adquiridas pelo governo do Estado. - R. de L.

- L, R. de. Exposição de Quadros, Artes e Artistas, O Estado de São Paulo, 31 de dezembro de 1907

\section{7.}

O pintor Oscar Pereira da Silva foi ontem a[o] palácio convidar o sr. presidente do Estado para assistir ao encerramento da exposição de quadros que o distinto artista instalou no salão do "Progredior".

O dr. Jorge Tibiriçá prometeu aceder ao convite.

Por esse motivo e também porque muitas pessoas ficaram privadas de ver a grande tela a "Fundação de S. Paulo", Oscar da Silva resolveu encerrar só daqui a dias o seu belo certame.

Ontem, a exposição foi muita(sic) concorrida, achando-se entre os visitantes, o sr. d. Duarte Leopoldo, bispo da diocese.

- EXPOSIÇÃO de quadros, Artes e Artistas, O Estado de São Paulo, 01 de janeiro de 1908.

\section{7.}

Sabemos que o conhecido pintor Oscar Pereira da Silva, professor de desenho do Ginásio do Estado, vai apresentar brevemente no Congresso do Estado um memorial, propondo a venda ao Estado do seu quadro a óleo, de quatro metros de comprimento por dois de altura, "A Fundação de S. Paulo".

Esse quadro esteve durante algum tempo em exposição, nesta capital, merecendo francos elogios dos entendidos.

ARTES e Artistas, O Estado de São Paulo, 13 de julho de 1908. 


\section{8.}

Não houve ontem sessão nesta casa do Congresso,por falta de número legal.

No expediente foi lido uma petição do pintor Oscar Pereira da Silva, propondo a venda de seu quadro representando a fundação de S. Paulo.

CAMARA dos Deputados, Congresso Legislativo, O Estado de São Paulo, 24 de julho de 1908

9.

O pintor Oscar Pereira da Silva dirigiu ao Congresso do Estado a seguinte petição:

“Digníssimos senhores membros da Câmara dos Deputados do Estado de S. Paulo, o abaixo assinado, pintor nacional, residente nesta capital, há doze anos, e professor de desenho no Ginásio do Estado, onde com todo o seu esforço e dedicação, ensina a futura geração de S. Paulo, a mais nobre das artes, qual seja a pintura, ousa pedir a vossa elevada e esclarecida atenção para a petição seguinte. Há muito que o suplicante tem feito diversas exposições de seus trabalhos neste Estado, procurando a custa de todos os sacrifícios perpetuar na tela todos os assumptos que dizem respeito a origem, modas, costumes, paisagem e evolução deste glorioso Estado - hoje, primeiro da nossa República. Faltava-Ihe, porém, um que preocupava e obrigava a sérios estudos de etnografia, civilização, geológicas e históricas para a fiel execução de um quadro representativo dos mais importantes acontecimento para a terra dos Bandeirantes - A fundação de S. Paulo. Este quadro dá a perfeita compreensão ao estrangeiro e até ao próprio nacional de tão importante fato, quando visitar o nosso museu, a nossa Pinacoteca do Estado. Pintado com esmero ele apresenta quatro metros de comprimento por dois metros de altura, vendo-se o acontecimento em que tomaram parte o nobre Anchieta, o padre Manuel da Nóbrega, o padre Manuel Paiva e os índios Caiuby e Tibiriçá em imponente e solene atitude no mesmo lugar em que tem sede, hoje, o honrado governo do Estado. Em exposição por muitos dias, recebeu os mais sinceros elogios por parte da imprensa desta capital.

Acresce ainda: todos os Estados do Brasil possuem de longa data, o quadro de sua fundação. São Paulo, não adquiriu ainda o quadro de sua fundação, nem tinha sido até agora pintado. Crente que não verá perder-se este seu grande esforço o seu pintor 
ousa propor a esta respeitável e ilustrada câmara a venda do mesmo pela quantia que oportunamente será fixada.

Respeitosamente vos agradece o deferimento.

-ARTES e Artistas, O Estado de São Paulo, 28 de julho de 1908.

10.

Visitamos, há dias o atelier do pintor Oscar P. da Silva o conhecido artista trabalha sempre, nas horas que lhe permitem as lições a que foi obrigado a recorrer nesta capital artística. As paredes do atelier estão cobertas de trabalhos, numa variedade muito interessante; quadros feitos na Europa, telas pintada aqui, esboços, estudos, etc. Em todos Oscar Pereira da Silva deixa sinais evidente de sua técnica superior. Um belo estudo da cabeça de mulher feito quando o artista ainda estava na Europa, é um primor de Desenho. Os traços vigorosos, seguros, magistrais ainda estão à mostra, atestando a firmeza da mão que os executou, enquanto as tintas atiradas em leve, porém, largas pinceladas, marcam já o modelado. O cabelo, feito por assim dizer de um só gesto, é, entretanto, ondeado e fractua (sic).

Ao lado deste encontram-se outros estudos. Uma vilegiatura recente em Santo Amaro ofereceu ao conhecido pintor a oportunidade de reproduzir algumas paisagens da localidade cenas da vida caipira. São pequenas telas cheia de luz, do desenho quase sempre irrepreensível, de observação feliz e rigorosa técnica.

Entre todos destacam-se duas grandes telas que valeram ao pintor o grande premio da exposição regional. A menor, um busto de velho, faz lembrar as velhas pinturas da escola flamenga, no seu toca muito e no vigor do modelado. A outra é uma soma do interior e do interior paulista ou, melhor dito, paulistano taque ao mesmo pequenino meio artístico. A cabeça da velha, na qual o artista pos evidentemente o seu maior cuidado, é um trabalho digno de francos elogios; e a luz que desse sobre Ella espalhando-se no rosto com a exatidão de uma águia real, ainda mais ressalta os primeiros desse magnífico trecho da tela. De resto tudo o mais é bem executado, da perfeita harmonia; não se vêm efeitos preparados; o quadro é o que o cenário podia dar.

Notaremos, apenas, que ao fogo seria necessário avivar um pouco mais e que a posição da velha carece um pouco de naturalidade, daquela naturalidade que se percebe nas feições do rosto. 
Em todo o caso são duas telas de real valor que representam trabalho de longo tempo e que não deram ao artista, até agora, senão a satisfação moral de um grande prêmio. Parece-nos que, se há uma verba para enriquecer a nossa incipiente pinacoteca, uma parte dela não seria mal aplicada num desses quadros de um pintor brasileiro, residente em S.Paulo e cujas qualidades artísticas são incontestáveis.

Ao menos, os principiantes que ali fossem buscar nas copias os elementos de aprendizagem, ganhariam, reproduzindo-os, boas noções de desenho e de pintura, o que aliás se não pode dizer de muitos quadros que figuram naquela coleção oficial por gordos preços. $-\mathrm{J}$.

J., Oscar P. da Silva, Artes e Artistas, O Estado de São Paulo, 11 de maio de 1909.

11.

"Fundação de São Paulo", quadro histórico de Oscar Pereira da Silva, exposto atualmente numa das salas do antigo Palácio Episcopal, a rua do Carmo.

Oscar Pereira da Silva convidou-nos a ver a sua tela histórica sobre a fundação de S. Paulo. Esse trabalho pictural do distinto e conhecido artista foi executado já há algum tempo e mesmo já esteve exposto no vasto salão do "Progredior". A crítica prenunciou-se então favoravelmente a esse quadro cuja tela mede cerca de três metros de largura, sobre dois e pico de altura. Desde então esse trabalho de Oscar só tem conservado no seu atelier de pintura, à espera de saída, isto é, de uma compra razoável, atenta a sua valia artística. Infelizmente não achou até agora comprador para seu quadro o distinto pintor, e, vendo ele que ficaria injustamente esquecido um trabalho de arte, em que gastou cerca de dois anos na sua concepção e, factura, deliberou expo-lo novamente, para que atraísse a atenção do governo estadual, visto que naturalmente se destina a ocupar um lugar na pinacoteca do Estado, atendendose ao seu assunto histórico, que é o da fundação de S.Paulo.

O crítico de arte desta folha, com estas linhas, não pretende, de forma alguma, sugestionar o benemérito governo estadual para que adquira o quadro. Á fundação de S.Paulo, mas leva unicamente em mira patentear o valor dessa tela, em que Oscar evidenciou as suas poderosas faculdades de artista, já na evocação dos tipos que nela 
figuram, em dado momento da nossa historia e na reconstrução topográfica do cenário em que os coloca, já na sua composição e realização artística.

Entretanto, não podemos dissimular o nosso desejo de ver figurar na pinacoteca do Estado a Fundação de S.Paulo entre a Partida da Monção de Almeida Junior, e o Grito do Ipiranga de Pedro Américo.

O quadro de Oscar Pereira da Silva merece bem esse lugar.

O autor fixou na tela, servindo-se de elementos colhidos na historia da terra paulista, o momento em que o padre Manual da Nóbrega, após dizer missa, se dirige ao local que foi denominado S.Paulo de Piratininga, e, ladeado dos jesuítas José de Anchieta e Manuel de Paiva, que empunha um crucifixo hasteado, celebra a cerimônia religiosa do benzimento desse local, em que atualmente se acha o palácio do governo (antiga igreja do Colégio dos Jesuítas), enquanto alguns irmãos da mesma Companhia de Jesus, aqui e ali, distribuem rosários pelos selvagens recentemente batizados, à frente dos quais se notam Caiubi e Tibiriçá. Anchieta, não, figura no quadro como celebrante, porque a esse tempo contava apenas 22 anos de idade, apesar de ter sido ele quem, com o concurso de onze religiosos, edificara a rústica vivenda que ao fundo se vê, o cavaleiro sobre a lombada da serra, que fica entre o rio do Tamanduateí e a ribeira do Anhangabaú. Do pátio do antigo Colégio parte, na direção do sul, o caminho velho do mar,como se observa na tela, pela atual rua do Carmo,descendo para a várzea, onde se vê o Tamanduateí, para alem do qual, enfumando-se nos longes, se escalonam as colinas distantes, aveludadas pela velatura de uma nevoa, aqui e ali esgarçada.

A Fundação de S. Paulo, como acabamos de descrever, é um quadro histórico de composição, cuja elaboração árdua e difícil tomou muito tempo ao seu autor.

O artista, terminada a leitura de trecho histórico que lhe prendeu a atenção e lhe sugeriu assunto, teve ainda naturalmente, de consultar qualquer desses velhos cronistas coevos, tão ricos em pormenores. Elucidado por esta forma acerca da localidade em que a ação se passa, do caráter dos seus personagens e das condições respectivas em que se encontravam no momento dado que escolheu para reproduzir, tratou ele de formar idéia exata e positiva do seu aspecto material. Para esse fim, recorreu ao nosso museu, investigou nas bibliotecas os documentos gráficos coevos e as recopilações de trajos, armas, construções, etc., e que o fez compenetrar-se do verdadeiro caráter da época e cunho histórico do assunto. Colhida assim a ideia do conjunto dos elementos com que teve de contar na sua composição, tratou de a esboçar a traços largos, modificando o esboço sucessivamente, até que lhe determinasse a disposição definitiva. Fixada a composição no papel, por meio de um 
desenho (desenho de dimensões relativamente avultadas, posto que inferiores ás do futuro quadro), trabalho preparatório que o habilitou a prever o alcance da composição, sob o ponto de vista do desenho, harmonia de linhas, lógica de ação, efeito geral do claro-escuro, etc., repetiu-a em um esboceto pintado, largamente, e pouco acusado nos pormenores para calcular o efeito do colorido.Transportou em seguida as linhas gerais da composição para a grande tela, servindo-se da quadricula, porque a superabundância das figuras e outros elementos assim o exigiram. Feito isto, começou para o artista o período mais árduo e laborioso da tarefa: o estudo.

Esse período ainda é mais árduo para o artista brasileiro, porque, em vista do não haver modelos, tem de se servir de manequins para estudos circunstanciados de roupagens. De sorte que o pintor teve de recorrer naturalmente a manequins e imaginar neles a expressão, o movimento e a atitude que necessitava de imprimir em cada figura, com os respectivos trajos, armas e utensílios, no momento da ação. Além de que teve ele de reunir, no seu atelier os demais acessórios que tomaram parte na composição, objetos esses que Ihe custaram boa soma de dinheiro. Outra dificuldade Ihe surgiu de pronto, no tocante ao lugar da ação, cujos elementos, como sejam os de paisagem e outras exterioridades, estudou, senão por forma completa (atenta a impossibilidade de os encontrar no natural em condições que perfeitamente correspondessem às exigências do assunto), ao menos parcialmente, copiando os desenhos e estudos pintados para the servirem de guia no decurso do seu trabalho.Mas pensam, por acaso, que acabou aqui o busilis de tamanho labor? Enganam-se. Para determinar com absoluta verdade a afinidade entre o fundo e as figuras, teve o artista de transportar a sua tela, já para o ar livre, já para um recinto qualquer, cujas condições de luz e de aspecto estivessem mais em harmonia com as da cena que desejava reproduzir. É que a arte da pintura moderna exige que o artista se inspire diretamente da Natureza, para que a sua obra tenha um cunho de intensa e duradoura vitalidade.

Foram essas as fases do trabalho que custou a Oscar Pereira da Silva a elaboração da sua tela de composição - a Fundação de S.Paulo, talqualmente as do labor de todos os artistas que empreendem pinturas congêneres.

Pintar uma tela dessas num meio artístico como o nosso, tão desfavorecido de incentivos orça por um verdadeiro heroísmo sem nome porque, alem de serem avultadas a despesas, que o artista faz para esse fim surge diante dele o fantasma de uma entre mil probabilidades de não encontrar para seu trabalho, futuramente, alguém que o compre compensando-o de tantos esforços, de tantas fadigas de tantos dissabores. 
Mas Oscar, depois de dois anos de incessante labor conseguiu fazer uma tela histórica de indiscutível merecimento artístico?

É o que vamos ver.

No concernente a composição Oscar Pereira da Silva respeitou antes de tudo a lei da convergência dos efeitos de que Taine faz, tanta questão, já no seu caráter em geral, já na ação, já no estilo. É o que nos pareceu pelo menos após uma analise do seu quadro. Nenhum elemento diz Taine, no seu livro De Ideal Dons Part deve ficar inativo ou desviar para outro objeto a atenção, seria força perdida ou uma força empregada contraproducentemente.

Se o pintor, por esse lado, não desperdiçou a força de cada elemento de sua tela, não é menos exato que muito concorreu para isso a lógica espontânea da concepção artística, devido ao temperamento e estudos do autor, notadamente quanto aos estudos da figura, cujo desenho constitui um dos elementos mais importantes da educação de um artista.

Oscar Pereira da Silva estudou na Europa e adquiriu seguros conhecimentos na aula de modelo vivo, mas o que mais é, estudou a figura na paisagem, habituando-se a reproduzi-la com largueza e flexibilidade de movimentos e procurando interpretá-la em harmonia perfeita com a paisagem que ela tem de animar.

"A figura, na paisagem, diz um escritor especialista no assunto, constitui sempre uma nota dominante, tanto no em que diz respeito á forma, como sob o ponto de vista da cor; é indispensável, portanto, para que ocupe bem o lugar que lhe compete e esteja em perfeito acordo com o espaço e a luz, do quadro, que o artista, na sua execução, atenda de preferência á expressão geral do contorno e dos valores (quer dos tons, quer incidentes mais gerais do claro-escuro).

Graduar bem os pormenores descritivos das figuras, sem cair em mesquinhez ou dureza,é uma das exigências mais indispensáveis neste ramo artístico. Uma figura, meticulosamente acabada, embora ocupe um lugar conspícuo no, primeiro plano de qualquer [ilegível] prejudicara as mais,das vezes o quadro, perdendo,alias, em vida o movimento o que porventura poderá ter ganho em perfeição mecânica de execução."

O autor da Fundação de S.Paulo não se esqueceu destas regras no tocante á composição de suas figuras que tomam parte na cena do benzimento do local denominado S. Paulo de Piratininga cheia de vida e rica de expressão religiosa.

A figura de padre Manuel da Nóbrega está bem desenhada e bem movimentada no gesto da benção; a do Anchieta, posto que secundaria no quadro, não é apenas um 
boneco: sem vida; outrossim a do padre Manuel de Paiva. As figuras dos índios, caracteristicamente vestidos salientam-se igualmente pela correção do desenho e pela sua animação no gesto e na fisionomia, principalmente uma que esta ajoelhada no primeiro plano, resguardada pela sombra do arvoredo, num destaque de forte colorido.

O quadro todo unge-se de tal religiosidade que, ao mesmo tempo que alastra por todas aquelas almas uma onda suave e mansa do misticismo cristão, se impõe por um largo toque de grandeza, ante aquele gesto de paz e de concórdia do padre Manoel da Nóbrega, na lombada da montanha, em plena luz que se difunde pelo céu e pela terra.

A iluminação é soberba; justo o colorido; bela a perspectiva; magníficos os ares; céu azulado de uma enganadora transparência; admiráveis ao longe.

A Fundação de S.Paulo é, portanto, uma tela de valor, que bem merece o destino a que já nos referimos.

Diante dessa tela, acode-nos ao bico da pena o trecho de Chaignet:

A natureza é o teatro da vida do homem, e os aspectos parecem harmonizar-se com os nossos,pensamentos. Ha mais por uma ilusão voluntaria, mas instintiva, prestamos uma alma aos objetos, imaginamo-los á nossa semelhança, refletimo-nos neles; há, pois, ao menos por nos e para nós, um ideal na natureza: a arvore inédita, a fonte soluça, o vento suspira, a luz brinca e ri. Somos nós que depomos a vida na natureza e ali a admiramos depois. É pois já um ato estético, um ato de artista, gozar as belezas da natureza, e atribuir um caráter moral as sua produções e os seus espetáculos."

Ainda bem que existem artistas, nos tempos ásperos e hoje, em que o industrialismo avassalou tudo, artistas do valor de Oscar Pereira da Silva, que nos enlevam com a inspiração e factura de seus quadros, proporcionando-nos alguns momentos de intenso gozo artístico.

Oxalá que o pintor do quadro Fundação de S. Paulo alcance uma justa compensação aos esforços que despendeu para pinta-lo.

- REGISTRO de Arte, Correio Paulistano, 4 de Agosto de 1909.

12.

Por certo a pintura é dentre as Belas-Artes a que maior numero de artistas notáveis tem fornecido ao nosso país. 
Relembrando no passado o nome de artistas geniais como Pedro Américo, não é possível esquecer esta plêiade de modernos que figuram:

Rodolpho Amoedo, P. Weingartner, Elyseo Visconti e muitos outros.

Seria injustiça não incluir no meio d'estes um grande artista que vive entre nós, Oscar P. da Silva; é de seu último trabalho que queremos falar.

Muito moço ainda, obtendo premio de viagem á Europa, na Academia de Belas-Artes no Rio, seguiu ele para Paris, onde estudou seis anos. Ai chegado, dois anos depois, expunha no Salon consecutivamente em 1892 e 1893. Foi em Paris que ele trabalhou estas conhecidas e magníficas telas que são: Escrava Romana, Infância de Giotto, Recomendeur de Faïence, Mediant dans La Cour.

Voltando ao seu país, estabeleceu-se em S. Paulo e aprofundou-se na Historia Pátria compôs a Descoberta do Brasil e muito proximamente o seu magnífico trabalho "A fundação de S. Paulo".

Quem tiver ocasião de observar esta grande tela que mede $4,{ }^{m} \times 2,{ }^{\mathrm{M}} 5$ verá que, obedecendo fielmente á verdade histórica, Oscar Pereira apresenta-nos um estudo completo de figuras e uma esplendida paisagem.

No primeiro plano o artista nos oferece um estudo minucioso de corpo humano; é assim que ele delineia em posições difíceis vários índios quase nus.

Mais adiante está o padre Nóbrega lançando a benção ao solo onde se deve fundar a cidade, finalmente no segundo plano divisam-se as figuras de vários religiosos entre os quais o padre Anchieta e depois uma paisagem longínqua, cheia de poesia e beleza, onde o pintor, raro conhecedor do colorido, copiou com mão de mestre a natureza imponente da nossa terra.

É por isso e por muito mais que, de baixo da aparência modesta, Oscar Pereira possui um temperamento artístico que é naturalíssimo descrevendo as linhas do corpo humano ou os traços da fisionomia, é realíssimo apanhando a natureza n'uma paisagem ou n'uma marinha, quando a grandes golpes de pincel traça na tela uma nuvem densa ou o colorido brilhante de um por do sol.

Russel - 2-10-909

RUSSEL, Oscar P. da Silva, Revista Santa Cruz, Ano X, no.1 Outubro de 1909 
13.

O sr. Dr. Carlos Guimarães, secretário do interior, visitou há dias o atelier do distinto pintor Oscar Pereira da Silva, dispensando francos elogios aos seus trabalhos, especialmente o grande quadro histórico "Fundação de São Paulo", a tela de gênero "Canto de Cozinha", que obteve prêmio na Exposição Nacional de 1908, o quadro "O mosqueteiro", e os esboços dos soberbos painéis com que aquele artista está decorando a igreja de Santa Cecília.

S.s. apreciou ainda outros trabalhos do ilustre artista e do talentoso discípulo José V. Rodrigues, cujos excelentes quadros Ihes valeram um auxílio para estudar pintura na Europa, por parte do governo do Estado

- OSCAR Pereira da Silva, Artes e Artistas, O Estado de São Paulo, 5 de outubro de 1909

14.

Presentes 27 srs deputados, abre-se a sessão.

São lidas, postas em discussão e aprovadas as atas da sessão e reunião anteriores.

No expediente é lido o seguinte:

Petição do artista Oscar Pereira da Silva oferecendo à requisição do Estado o seu quadro Histórico - "Fundação de São Paulo" - à Comissão de Fazenda e Contas

SESSÃO de 5 de outubro, Câmara dos deputados, Congresso do Estado, Noticiário, Diário Oficial do Estado de São Paulo, 06 de outubro de 1909.

15.

Presentes os 26 srs. deputados, abre-se a sessão.

É lida, posta em discussão e apreciada a ata da sessão antecedente.

No expediente é lido o seguinte:

$(\ldots)$

São aprovados os pareceres:

Mandando ouvir o Governo sobre a proposta de venda do quadro histórico "A Fundação de S. Paulo" do artista Oscar Pereira da Silva; 
SESSÃO de 14 de outubro, Câmara dos deputados, Congresso do Estado, Noticiário, Diário Oficial do Estado de São Paulo, 15 de outubro de 1909.

16.

$[\ldots]$

No expediente é lido:

Ofício do sr. secretário da Agricultura [...]

Idem do sr. secretário dos Negócios do Interior, enviando as informações solicitadas sobre uma proposta para aquisição, pelo Estado, do quadro histórico "A fundação de S. Paulo", do artista Oscar Pereira da Silva. - À comissão de Fazendas e Contas.

SESSÃO em 26 de novembro, Câmara dos deputados, Congresso do Estado, Noticiário,

Diário Oficial do Estado de São Paulo, 27 de novembro de 1909.

17.

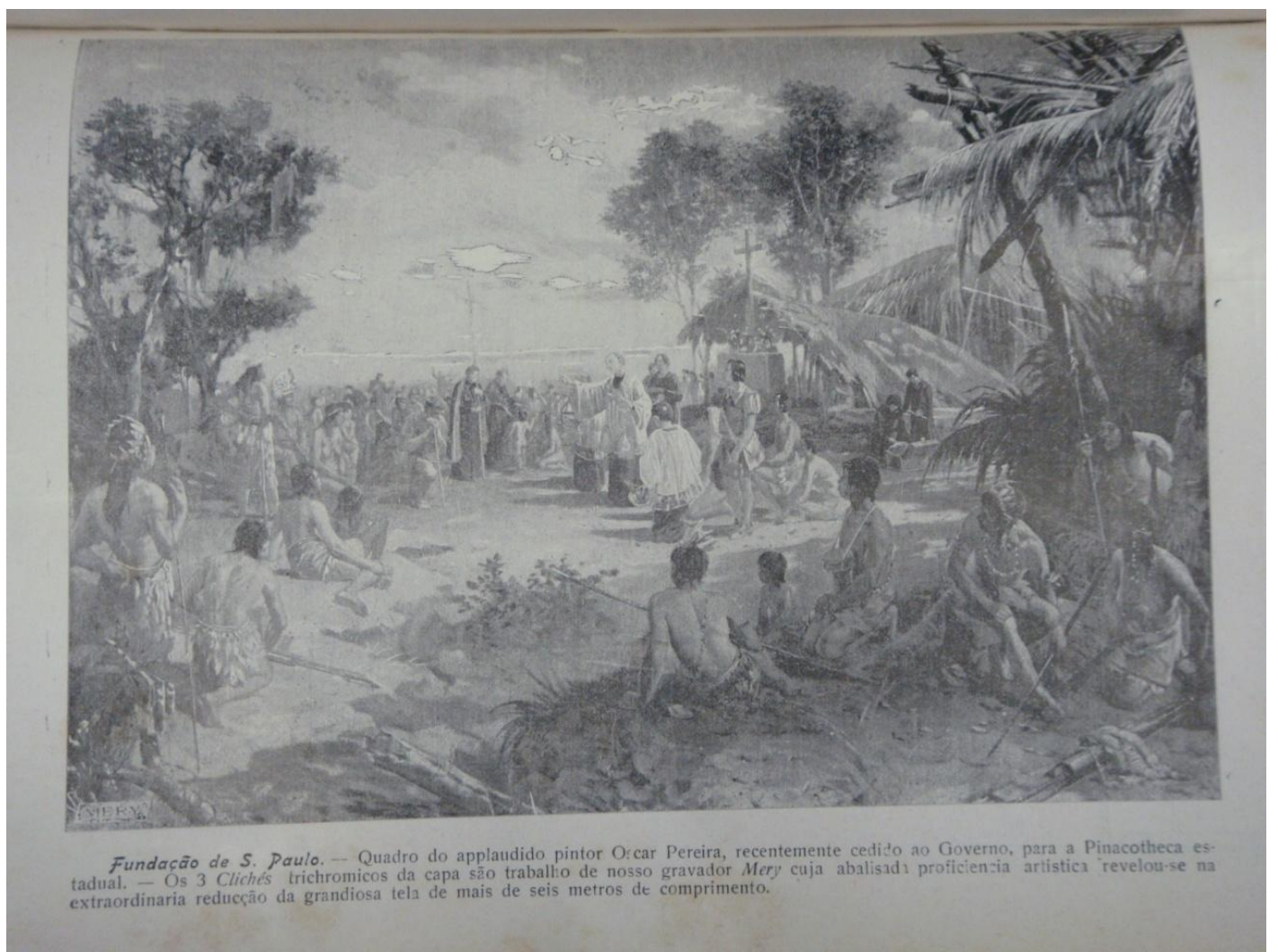


Fundação de São Paulo - Quadro do aplaudido pintor Pereira, recentemente cedido ao Governo, para a Pinacoteca estadual - Os 3 clichés trichromicos da capa são trabalho de nosso gravador Mery cuja abalisadora proficiência artística revelou-se na redução da grandiosa tela de mais de seis metros de comprimento.

- Revista Santa Cruz, Ano X no. 5 fevereiro

18.

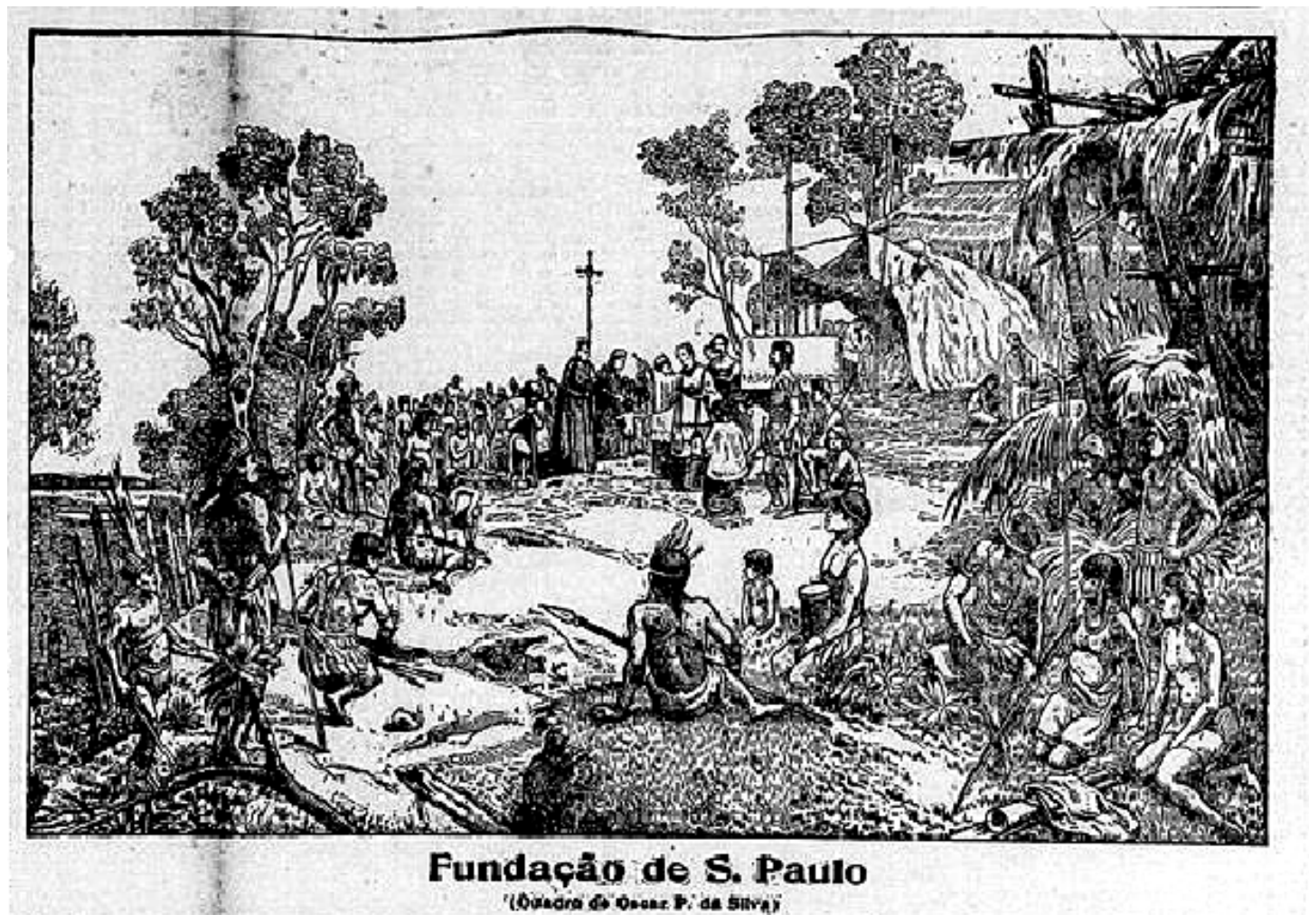

Ao transpor a serra de Paranapiacaba, pelo caminho velho, atingindo a região do planalto ou do campo, o viajor ia dar de frente com um pequeno rio, denominado outrora - Piratininga (Seca do peixe, segundo T. Sampaio), e seguindo seu curso sinuoso e manso, através do referido planalto que tinha o seu nome, cerca de três léguas, surgia, em meio de extensa várzea, uma pequena eminência ou lombada de campo alto, que era contornada, pelo nascente, por aquele rio, e ao norte, por um ribeirão, denominado - Anhangabaú (rio da maldade ou maléfico, conforme $\mathrm{T}$. Sampaio).

Essa colina, medindo cerca de 15.000 braças quadradas e tendo de vinte e cinco a trinta metros de alto ( $T$, Sampaio), foi o local predestinado, onde se realizou 0 
memorável fato histórico, que celebramos nesta data - isto é, a fundação da primeira capela o da primeira escola, em terras de Piratininga.

E, pois, bem se pode dizer que, nesta data, lançou-se os primeiros fundamentos da cidade de S. Paulo, sob o ponto de vista religioso e intelectual, embora sob o aspecto administrativo, só se efetuasse tal fundação, seis anos depois, em 1560, em virtude da provisão do governador Mem de Sá.

A 25 de janeiro, dia em que a Igreja celebra a festa da conversão de S. Paulo, o Apóstolo das Gentes era justo que iniciasse a obra grandiosa da catequese e o estudo das línguas indígenas, para encaminhar o devassamento do sertão e a conquista do território para o Evangelho e para a civilização.

Pouco antes, treze religiosos da Companhia de Jesus, entre eles, o noviço José de Anchieta, mais tarde transfigurado, pelas virtudes e zelo, em Taumaturgo da America, haviam erguido, na colina aludida, em face para o Piratininga (atual sítio ocupado pela secretaria da Polícia) "uma cabana, coberta de palha, com as paredes de taipa de mão, não tendo mais de quatorze passos de comprimento e dez de largo. Servia ela, ao mesmo tempo, de escola, enfermaria, dormitório, refeitório, cozinha e dispensa."

Eis como no-la descreve o próprio Anchieta, em sua linguagem ingênua expressiva.

Em frente a essa choupana, o Padre Manuel de Paiva, chefe daquele pugilo de bravos soldados de Cristo, celebrou neste dia, o sacrifício da Missa, com a assistência de catecúmenos e de indígenas, atraídos pela singularidade do fato.

Verdadeira missa campal - deveria o ato revestir-se de uma beleza e solenidade sem iguais: - a hora matinal, o azul diáfano do céu, arqueando-se em curva majestosa, como um docel de turquesas, sobre o altar improvisado; os raios do sol nascente, aureolando suavemente a cruz dominadora; o verde da folhagem, realçando a candidez da hóstia do sacrifício, na elevação; os gorgeios melodiosos da passarada, em desafio com o tinido estridente da campainha, o cicio da viração, nas folhas do arvoredo próximo; a atitude, a um tempo perplexa e respeitosa, dos indígenas de cor bronzeada e com suas armas garridas e estranhas; a bênção final do sacerdote, ecoando ao longe, no descampado deserto, até as tabas indígenas, como um brado de Pedro o Eremita, conclamando os cristãos para a reconquista da Terra Santa!

Ao lado dos religiosos genuflexos, ali se achavam os chefes indígenas - Tibiriçá e Caiubi, os quais posteriormente localizaram suas tabas na parte norte da colina - 0 primeiro (largo de S. Paulo atual), e o segundo, na atual ladeira da Tabatinguera. 
O belo quadro do pintor Oscar Pereira da Silva, que damos em clichê reduzido, sugere uma pálida ideia da grandiosidade do fato, que descrevemos.

$(\ldots)$

J. C. Gomes Ribeiro

Correio Paulistano, 25 de janeiro de 1910

19.

Tratando-se de arte, em seção especial deste mensário, um nome que desde logo nos acode à memória é o de Oscar Pereira da Silva, um veterano da pintura em São Paulo. Quer isto dizer que este artista já não é moço e pertence à velha geração em que fulgiram os nomes como o de Castagneto, Belmiro de Almeida, Antonio Parreira, Benjamin Parlagrecco e outros. Alguns desse grupo de pintores já não existem; outros, se existem, tão pouco fazem que não dão sinal de si como artistas. Tal geração vem de 1884.

Perguntará então o leitor indiscreto (ou curiosa leitora, que ainda se recorda da última fotografia de Oscar com as guias enristadas de uns lindos bigodes, mais pretos que 0 âmbar negro da Islândia): "Nesse caso, quantos anos contará o simpático pintor? A aritmética, neste ponto, não é nenhum quebra-cabeças, pois basta dizer que Oscar Pereira da Silva nasceu em 27 de agosto de 1867. Quid inde? Nem por isso (que lhe importa uma dezena de lustros?) deixou ainda o nosso querido artista de pintar quadros e, chi lo sa? De pintar a manta, o padre, o caneco, uma vez que não é para ai nenhum Fra Angelico.

O caso é que Oscar Pereira da Silva tem rijo cerne, forte arcabouço e um bíceps branquial que ainda não treme, quando ele impunha o pincel e a palheta. Daí a sua laboriosidade que serve de exemplo a muitos moços de hoje, precocemente envelhecidos e quase inativos no struggle for life.

Dá-se com o escritos destas linhas um caso interessante, em relação ao nosso pintor: de cada vez que o encontramos, afigura-se-nos ver a imagem do saudoso Almeida Júnior, não pelo aspecto físico, mas pelo lado espiritual. É que a psicologia de ambos é quase a mesma, a certos respeitos. Almeida Júnior, étnica e fisicamente, era um pitoresco tipo de paulista: não passou nunca de um simples, na aparência física e na 
alma de artista. Apesar de haver ele vivido durante muito tempo em Paris, tece sempre um aspecto modesto provinciano, inalteravelmente roceiro, blindado essa grossa casca de caipira, que confia mais em si próprio do que nos outros.

Muito modesto, nos ademanes e no trajar, onde quer que ele estivesse, apagava-se, anulava-se, esbatia-se. Conta-se mesmo que na Academia de Belas Artes, quando estudante, os colegas metiam à bula, despiedadamente, o seu tipo de provinciano; e, quando ele falava, com a boca muito aberta, cantando as sílabas finais das palavras, faziam-Ihe troça, montejavam-no, satirizavam-no.

Para se fazer mesmo uma ideia da irredutibilidade caipira do canhestro caboclo que foi Almeida Junior, narra-se ainda o seguinte fato: indo a Paris um brasileiro importante, pediram-Ihe para visitar o atelier de Almeida Junior notar os progressos que ele conseguira em três ou quatros anos. Satisfazendo ao pedido e aceitando incumbência, foi ter com o artista brasileiro. Admirou de vê-lo. O moço conservava ainda os mesmos gestos, o mesmo tipo desconfiado e tímido, a mesma maneira de falar dos caipiras. $O$ que fez, sobretudo, pasmar o visitante foi ouvi-lo dizer:

- Istou morto por mi pilhar no Brásil!

Pois o temperamento crioulo de Almeida Júnior, assim apanhado em flagrante, no seu atelier de Paris, nunca mudou e, aqui como lá, foi sempre o mesmo. E isto o impediu porventura de ser o grande criador da pintura nacional e de ser, na arte paulista, de par com Carlos Gomes, o nosso maior padrão de glória?

A modéstia é um grande lastro do verdadeiro engenho, na expressiva frase de Machado de Assis; e o dandismo, ao que parece, jamais se tornou o apanágio dos artistas de gênio.

Eis o ponto de semelhança entre Almeida Junior e Oscar Pereira da Silva. Este é também um retraído, um contemplativo, um acanhado; não se Ihe nota na toilette o mais insignificante indiculo (sic) de querer sobressair; traja-se ele como qualquer burguês, e nos seus gestos, e no seu modo de falar, não há tamanha vivacidade que nos dê na vista. Entretanto, Oscar Pereira da Silva, na atualidade, é o nosso maior artista do pincel.

Nosso - dissemos; mas, que dirá o leitor, se souber que ele nasceu em São Fidelis, município de Campos, Estado do Rio de Janeiro? Que importa! Oscar Pereira da Silva aqui tem vivido a maior parte da sua existência. São Paulo tem sido o principal teatro da sua atividade artística, ao mesmo tempo que lhe tem dado grande apoio e prestado ininterrupta demonstração de apreço. Não é um paulista de nascimento; mas é um paulista adotivo, como o foram Ezequiel Freire, Theophilo Dias e outros homens 
ilustres, que se adaptaram ao nosso meio e receberam dele incentivos para as suas produções.

Pode-se dizer mesmo que São Paulo por ele tem feito mais do que por muitos de seus filhos aqui nascidos. Assim é que o nosso governo, por duas vezes o manteve, a expensas suas, em Paris, o tem agora como professor do Ginásio do Estado, nesta capital e já adquiriu para a Pinacoteca de São Paulo, as telas de sua lavra: Criação da Vovó, Escrava romana, pedant La pose, Fundação de São Paulo em 1554. Além disso, por incumbência dos engenheiros construtores do nosso Teatro Municipal, pintou ele magníficos painéis decorativos no platfond do grande salão daquele teatro, representando o teatro grego, ladeado da Dança e da Música Profana (trabalho feito in loco).

Sobre o grande quadro histórico Fundação de São Paulo em 1554, cumpre dizer que já tivemos ensejo de escrever algures mais amplamente, e podemos já agora declarar que esse nosso artigo de crítica, patenteando-lhe o valor incontestável, produziu o procurado efeito - qual o de chamar a atenção do governo para ele e de the despertar a ideia de adquiri-lo, o que aconteceu com grande gaudio para o pintor e para o crítico.

Da obra pictural de Oscar Pereira da Silva, não há negar, a tela histórica a que nos referimos com tantos gabos, é quiçá a melhor, sob certo e determinado ponto de vista. O pintor fixou nela um momento da nossa história e com ela nos legou um preciosissimo documento, cuja valia, como trabalho de evocação e de reconstrução, é inestimável para o historiador e para o artista. A pintura histórica, ao que parece, merece-Ihe especial cuidado, tal a exatidão com que faz reviver nas telas cenas e personagens da época que escolhe para estudar e reproduzir.

Como figurista, propriamente, é que é notável Oscar Pereira da Silva. Ninguém o excede nesse gênero. O estudo do nu já não tem para ele segredos de espécie alguma. Todos os quadros que fazem parte da Pinacoteca de São Paulo e que já enumeramos, são modelares nesse sentido. O nosso pintor cultua a forma como um pagão: é um perfeito heleno, mas forrado de expressionista hodierno.

Além dessas telas, existem outras nesta ou naquela galeria particular. Tais são: "Napolitana", uma lindeza como expressão e como colorido; "Sonho de Beethoven", uma bela visionação (sic) de artista inspirado, "Lydia", "Salomé", "Dalila e Sansão", "Infância de Giotto" e tantos outros trabalhos do gênero figurista, em que dignos de nota são o desenho, o colorido, a iluminação, a vida expressiva do facies e de todo o corpo humano, aquele sentimento da carne, enfim, para nos servirmos de uma maneira de dizer admiravelmente significativa de esteta, o sentimento da carne que, 
não raro, é o desespero do artista e que pode ser a sua grande glória, como no caso pertinente. "Salomé", por exemplo, é a Kypris de hoje: é a deusa humana do hodierno sensualismo, perante a qual todos se prosternam, na missa negra do amor carnal.

Deste modo, a "Panoplia", abrindo espaço para o trabalho de Oscar Pereira da Silva, o qual fazemos acompanhar destas linhas de prosa ligeira, presta-Ihe merecida homenagem.

-QUEIROZ, Wenceslau. Oscar Pereira da Silva. Panoplia, julho/agosto de 1917

20.

Mais uma série de obras perfeitas encontrarão os nossos leitores, reproduzidas em trichromias, no presente número. São quadros de grande valor artístico, como é fácil verificar: A Pompeiana, de Zeferino da Costa - o mestre dos mestres -: Dois Irmãos, de João Baptista da Costa: Fundação de São Paulo, por Oscar Pereira da Silva, e Minha terra, de Hélios Scelinger. A Pompeiana pertence à coleção de obras de Zeferino, que está na Pinacoteca da Escola de Belas Artes, é uma bela obra desenhada com rigor absoluto: embora não sendo a tela mais bela do artista, é, entretanto, possuidora dos mesmos característicos que o mestre dos mestres emprestava a tudo que saía da paleta: A Pompeiana foi um quadro atacado pela crítica, porém, os ataques só serviram para realçar as qualidades do trabalho. A crítica veio ao encontro do pintor, explicando ao público o que ele não quis explicar...

Gonzaga Duque escreveu na sua Arte Brasileira, referindo-se ao mestre. "E entre os ditosos está Zeferino da Costa, um artista contemporâneo, dotado de um espírito solerte alentado pelo alvorear da mocidade.

Em Roma, onde estudou como aluno interno da Academia, compôs três quadros Óbulo da viúva, Moysés recebendo as tábuas da lei e Caridade, além de um considerável numero de estudos muito bons.

Nos dois primeiros quadros, percebe-se a colorista de uma têmpera, mas a Caridade, como concepção artística, é dos três o que mais valor possui. O motivo é simples, uma rica mulher chega à miserável choupana de uns necessitados: ao fundo, soerguida da enxerga, está entrevada a moradora desse casal obscuro, e na porta da entrada aparece um criado de libré com as previsões que este generoso coração traz á pobre."

$\mathrm{Na}$ bagagem de Zeferino encontra-se a formosa decoração da igreja da Candelária, a mais completa decoração religiosa do Brasil e talvez das Américas: nesse trabalho, o 
mestre emprestou toda sua alma de artista, por ele perdeu o maior bem da terra: a saúde, e acabou dando-lhe a vida...

O Dois Irmãos, de Baptista da Costa, representa uma negra da nossa terra, maravilhosamente transmudada para a tela.Foi oferecida ao Exmo.Sr.Dr. Antonio Jose de Almeida presidente da República portuguesa. A tela, além de ser uma magnífica obra de arte, tem o valor histórico, retrata um trecho da lagoa Rodrigo de Freitas, que já não existe: todo o primeiro plano foi inteiramente modificado e saneado pelos cães que contornam aqueles sítios. Sobre o mérito da paisagem não diremos uma palavra, seria monótono estarmos a repetir sempre os mesmos adjetivos. O público que seja juiz, distribua ao artista os louros que sem favor merece.

De Oscar Pereira da Silva é a Fundação de São Paulo, pertencente á Pinacoteca do Estado. É uma movimentada tela, cheia de sol e detalhes preciosos. O artista empregou o seu talento numa das composições mais ingratas e saiu-se maravilhosamente. O grupamento das figuras é de tal forma feito que agrada ao primeiro exame; as atitudes são sentidas e os movimentos compreendidos. As expressões revelam conhecimento perfeito da psicologia e fisiologia das paixões: 0 medo, a altivez, a indecisão, a desconfiança, o desprezo, a humildade, estão concretizados dentro dos silvícolas do quadro; tais sentimentos refletem-se nos gestos e na expressão do olhar.

A cena do fundo é encantadora, dentro da paisagem.

Oscar Pereira da Silva foi discípulo de J. Medeiros, Zeferino da Costa, Victor Meirelles de Lima e Chaves Pinheiro.

Matriculou-se na antiga Academia de Belas Artes em 1862 e terminou seu curso em 1887, quando tirou o prêmio de viagem à Europa, onde estudou com Jerome e Bounat.

- Nossas trichromias, Revista Ilustração Brasileira, Janeiro de 1923, Ano IV, no. 29 
FONTES CONSULTADAS

\section{Arquivo Público do Estado de São Paulo}

Periódicos

- O Estado de São Paulo (1900 - 1954)

- Correio Paulistano (1900 - 1954)

- Commercio de São Paulo (1907)

- Revista Santa Cruz (1913 a 1921, 1927 e 1929)

- Revista Moderna (1907)

- RevistaPanoplia (1917)

Documentos impressos ou manuscritos

- Arquivo pessoal Oscar Pereira da Silva

- Documentos sobre a Secretaria do Interior: correspondência, pareceres, ofícios, prestações de contas (1900 - 1913)

- Relatórios da Secretaria do Interior (1905-1907)

\section{Biblioteca da Faculdade de Arquitetura e Urbanismo da USP}

- Revista llustração Brasileira (1909-1910, 1929)

- Revista do Instituto Histórico e Geográfico de São Paulo (1899 - 1920)

\section{Biblioteca da Faculdade de Direito da USP}

- Revista Santa Cruz (1905 - 1912)

- Jornal do Commercio (1908 - 1909)

Biblioteca da Faculdade de Filosofia Letras e Ciências Humanas da USP

- Revista llustração Brasileira (1909-1910, 1921-1922) 
Biblioteca da Faculdade de Saúde Pública da USP

- Relatórios da Secretaria do Interior (1911)

Biblioteca da Faculdade de Teologia da PUC-SP

- Revista Santa Cruz (1909, 1927)

\section{Biblioteca Mario de Andrade}

- O Estado de São Paulo (1908-1909)

- Correio Paulistano (1908-1909)

Biblioteca do Museu Paulista da USP

- Revista llustração Brasileira (1929)

- Revista do Museu Paulista (1899 - 1912)

- Relatório Secretaria do Interior (1908 - 1910)

Biblioteca da Pinacoteca do Estado de São Paulo

- Relatórios e pastas de autores de obras da Pinacoteca do Estado (1905 -1954)

Centro de Documentação da Assembleia Legislativa do Estado de São Paulo

- Anais da Assembleia Legislativa (1900-1910)

- Documentos da Câmara dos Deputados (1900-1910)

Centro de Documentação e Memória da Pinacoteca do Estado de São Paulo

- Documentação referente à tela Fundação de São Paulo: correspondências, ofícios, notas ficais (1911 - 1991)

- Lei de regulamentação da Pinacoteca

- Livro do Tombo

- Catálogos de exposições (1911 - 1929) 


\section{Museu da Santa Casa da Misericórdia de São Paulo}

- Acervo iconográfico

- Documentação de obras de Oscar Pereira da Silva

Pinacoteca Municipal / Centro Cultural São Paulo / Prefeitura de São Paulo

- Quadro de Antonio Parreiras, Fundação de São Paulo, 1913. Óleo sobre tela, 200 x 300 cm. Localizada no Gabinete do Prefeito de São Paulo.

Serviço de Documentação Textual e Iconográfica do Museu Paulista da USP

- Coleções iconográficas

- Relatório Anual Museu Paulista (1907 - 1954)

- Inventáriosdo acervo $(1906,1925,1932)$

- Correspondências (1905-1910, 1928-1930, 1952-1963)

- Livro de Registro de Aquisições (1894 - 1939)

- Declaração de empréstimo e devolução de Acervo (1939 - 1963)

\section{Acervos online}

- Diário Oficial do Estado de São Paulo (1907-1910)

- Folha da Manhã (1954) 


\section{BIBLIOGRAFIA}

ABUD, Kátia. O sangue intimorato e as nobilíssimas tradições - a construção de um símbolo paulista: o bandeirante. São Paulo: USP. 242 p. Tese (doutorado) -Faculdade de Filosofia, Letras e Ciências Humanas, Universidade de São Paulo, São Paulo, 1985.

ALVES, Caleb Faria. Benedito Calixto e a construção do imaginário republicano. Bauru: EDUSC, 2003.

ANDERSON, Benedict. Comunidades imaginadas. São Paulo: Companhia das Letras, 2007.

ARGAN, Giulio Carlo. História da arte como história da cidade. São Paulo: Martins Fontes, 2005.

ARRUDA, Maria Arminda do Nascimento. Metrópole e Cultura - São Paulo no meio Século XX.Bauru, SP: EDUSC, 2001.

ARAUJO, Marcelo Mattos (org.). Pinacoteca do Estado: a história de um museu. São Paulo: Prêmio; Artemeios, 2007.

BACZKO, Bronislaw. Imaginário social. In ROMANO, Ruggiero (org.). Enciclopédia Einaudi,volume 5: Anthropos-Homem. Lisboa: Imprensa Nacional; Casa da Moeda, 1985, p. 296-332.

BARBUY, Heloisa. A cidade-exposição: comércio e cosmopolitismo em São Paulo, 1860-1914.São Paulo: Edusp, 2006.

BAXANDALL, Michael. O olhar renascente. Pintura e experiência social na Itália da Renascença. São Paulo: Paz e Terra, 1991.

BAXANDALL, Michael. Padrões de intenção: a explicação histórica dos quadros. São Paulo: Companhia das Letras, 2006.

BELLUZZO, Ana Maria de Moraes. Artesanato, arte e indústria. Tese (doutorado) Faculdade de Arquitetura e Urbanismo, Universidade de São Paulo, São Paulo, 1988.

BENCOSTTA, Marcus Levy Albino. Igreja e poder em São Paulo: D. João Batista Correa Nerya e a Romanização do Catolicismo Brasileiro (1908-1920). Tese de Doutorado, Faculdade de Filosofia, Letras e Ciências Humanas, Universidade de São Paulo, São Paulo, 1999.

BITTENCOURT, José Neves. O teatro da memória - palco e comemoração na pintura histórica brasileira. Projeto História, São Paulo, n. 20, p.153-162, abr. 2000.

BREFE, Ana Claudia Fonseca. Museu Paulista, Affonso de Taunay e a memória nacional (1917 - 1945). São Paulo: Editora Unesp; Museu Paulista, 2005.

BREFE, Ana Claudia (org). Pouvoirs: representer le pouvoir en France du MoyenÂge à nos jours. Paris: Somogy; Nantes: Musée du château des ducs de Bretagne, 2008. 
BROTERO, Frederico de Barros. Descendentes do ouvidor Lourenço de Almeida Prado: notas genealógicas.São Paulo: Escolas Profissionais Salesianas, 1938.

CAPELATO, Maria Helena Rolim; PRADO, Maria Ligia Coelho. O Bravo Matutino. Imprensa e Ideologia: O Jornal O Estado de S.Paulo. São Paulo: Alfa-Omega, 1980.

CAMPOS, Candido Malta. Os rumos da cidade: Urbanismo e modernização em São Paulo. São Paulo: Senac, 2002.

CARVALHO, José Murilo de. A formação das almas. O imaginário da República no Brasil, 19ạ. impressão. São Paulo: Companhia das Letras, 2009.

CARVALHO, Vânia Carneiro de; LIMA,Solange Ferraz de. São Paulo Antigo, uma encomenda da modernidade: as fotografias de Militão nas pinturas do Museu Paulista. Anais do Museu Paulista: História e Cultura Material, São Paulo, n. 1, p. 147-178, 1993.

CARVALHO, Vânia Carneiro de; LIMA, Solange Ferraz de. Desenhocop: o ensino através das imagens. Revista de História da Educação, Pelotas, v.14, p. 7-28, set. 2003.

CAVALCANTI, Ana Maria Tavares. Belmiro de Almeida (1858-1935), Oscar Pereira da Silva (1867-1939) e o polêmico concurso para Prêmio de Viagem de 1887. In: XXVI Colóquio do Comitê Brasileiro de História da Arte, 2007, São Paulo. Anais do XXVI Colóquio do Comitê Brasileiro de História da Arte. Belo Horizonte: Editora C/Arte, 2007, p. 266-274.

CHARTIER, Roger. O mundo como representação. Estudos Avançados,São Paulo, n.11(5), p.173-191, 1991.

CHARTIER, Roger. A história cultural: entre práticas e representações. Lisboa: DIFEL, 1990.

CHIARELLI, Tadeu. Gonzaga-Duque: a moldura e o quadro da arte brasileira. In: DUQUE ESTRADA, Luis Gonzaga. A arte brasileira. Campinas, SP: Mercado de Letras, 1995.

CHIARELLI, Tadeu. Anotações sobre arte e história no Museu Paulista. In: FABRIS, Annateresa (org.). Arte \& Política: algumas possibilidades de leitura. Belo Horizonte/ São Paulo: C/Arte / Fapesp, 1998, pp. 21-46.

CHRISTO, Maraliz de Castro Vieira. Bandeirantes na contramão da História: um estudo iconográfico. Projeto História, São Paulo, 24, pp. 307-335, jun.2002.

CHRISTO, Maraliz de Castro Vieira. Pintura, história e heróis no século XIX: Pedro Américo e "Tiradentes Esquartejado". Tese (doutorado), Instituto de Filosofia e Ciências Humanas, Universidade Estadual de Campinas, Campinas, 2005.

CHRISTO, Maraliz. Bandeirantes ao chão. Estudos históricos, Rio de Janeiro, n. 30, p. 33-55, 2002. 
COLI, Jorge. A Batalha de Guararapes de Victor Meirelles e suas relações com a pintura internacional. Tese (livre-docência), Instituto de Filosofia e Ciências Humanas, Universidade Estadual de Campinas, Campinas, 1995.

COLI, Jorge. Como estudar a arte brasileira do século XIX?..São Paulo: Editora Senac, 2005.

COLI, Jorge. Introdução à pintura de História. Anais do Museu Histórico Nacional, Rio de Janeiro, 39, p. 49-58, 2007.

COLI, Jorge. O sentido da batalha: Avahy, de Pedro Américo. Projeto História, São Paulo, n.24, p. 113-127, jun.2002.

COUTO DE MAGALHÃES, José Vieira. O Selvagem. São Paulo: Nacional, 1935.

CUNHA, Manuela Carneiro da.Os direitos do índio.São Paulo: Editora Brasiliense, 1987.

CRUZ, Heloisa de Faria (org.). São Paulo em revista: catálogo de publicações da imprensa cultural e de variedade paulistana 1870-1930. São Paulo: Arquivo do Estado, 1997.

DUQUE ESTRADA, Luis Gonzaga. A arte brasileira. Campinas, SP: Mercado de letras, 1995

FABBRI, Cleber Sebastião. O Estado de São Paulo. In: QUEIROZ, Adolpho e OLIVEIRA, Dennis de (orgs.).Jornais centenários de São Paulo. Piracicaba: Degaspari, 2002.

FERRARO, Mario Roberto. A gênese da agricultura e da silvicultura moderna no Estado de São Paulo. Dissertação (Mestrado), Escola Superior de Agricultura "Luis de Queiroz", Universidade de São Paulo, Piracicaba, 2005.

FERREIRA, Antonio Celso. A epopéia bandeirante: letrados, instituições, invenção histórica (1870 - 1940). São Paulo: Editora Unesp, 2002.

FERRETTI, Danilo José Zioni; CAPELATO, Maria Helena Rolim. João Ramalho e as Origens da Nação: os paulistas na comemoração do IV centenário da descoberta do Brasil. Tempo, Niterói, v. 04, n.08, p. 67-87, 1999.

FREITAS, Artur. História e imagem artística: por uma abordagem tríplice. Estudos históricos, Rio de Janeiro, n. 34, p. 3-21, jul.-dez. 2004.

GAGLIARDI, José Mauro.O indígena e a República. São Paulo: HUCITEC; Editora da Universidade de São Paulo; Secretaria do Estado da Cultura, 1989.

GOMES, Edgar da Silva. Se quisermos que tudo fique como está é preciso que tudo mude. In: XXVI Simpósio Nacional de História ANPUH - Anais. São Paulo: ANPUH, 2011.

GUARRILHA, Hugo. Crítica e pintura histórica nos periódicos do Rio de Janeiro no século XIX.Anais do Museu Histórico Nacional, Rio de Janeiro, 39, p. 215-240, 2007. 
GUIMARÃES, Manoel Luiz Salgado. Historiografia e nação no Brasil 1838-1857. Rio de Janeiro: Ed. UERJ, 2011.

GUIMARÃES, Manoel Luiz Salgado. Vendo o passado: representação e escrita da história. Anais do Museu Paulista: História e Cultura Material, São Paulo, v. 15, n. 2, p. 11-30, jul-dez 2007, p. 11-30.

GROLA, D. A. A memória nas Arcadas: construção material, simbólica e ideológica do edifício da Faculdade de Direito do Largo de São Francisco. São Paulo: Humanitas/Fapesp, 2012.

HOBSBAWM, Eric J; RANGER, Terence O.The invention of tradition.Cambrigde: University Press, 2000.

HOMEM, Maria Cecília Naclério. Antonio Prado, prefeito da cidade de São Paulo: 1889-1910. In: V Seminário da Cidade e do Urbanismo, 1998, Campinas. Cidades: temporalidades em confronto. Campinas: Pontifícia Universidade Católica de Campinas, 1998.

HOMEM, Maria Cecília Naclério. O Palacete Paulistano e outras formas urbana de morar da elite cafeeira (1867-1918). São Paulo: Martins Fontes, 1996.

LEVY, Carlos Roberto Maciel. Antonio Parreiras(1860-1937): pintor de paisagem, gênero e história. Rio de Janeiro: Pinakotheke, 1981.

LIMA, Solange Ferraz de. Pátio do Colégio, Largo do Palácio. Anais do Museu Paulista: História e Cultura Material, São Paulo, , v. 6/7 (1998-1999). Editado em 2003, p. 61-82.

LOFEGO, Silvio Luiz. IV Centenário da Cidade de São Paulo: uma cidade entre o passado e o futuro. São Paulo: Annablume, 2004.

LOS PINCELES de la historia - De la patria criolla a la nación mexicana, 1750-1860. Ciudad de Mexico: Banamex: Patronato del Museo Nacional de Arte, 2000.

LOS PINCELES de la historia - La arqueología del régimen, 1910-1955. Ciudad de. México: Patronato del Museo Nacional de Arte: Banamex, c2003.

LOS PINCELES de la historia - La fabricación del estado, 1864-1910. Ciudad de Mexico: Banamex: Patronato del Museo Nacional de Arte, 2003.

LOURENÇO, Maria Cecília França. Almeida Junior - um criador de imaginários. São Paulo: Pinacoteca do Estado, 2007.

LOURENÇO, Maria Cecília França. Vila Penteado: Memória e Futuro. In Vila Penteado: 100 anos. São Paulo: FAUUSP, 2002, p.94-105.

LOURENÇO, Maria Cecília França. (org.). Bens imóveis tombados ou em processo de tombamento da USP. São Paulo: Edusp, Imprensa Oficial do Estado de São Paulo, 1999. 
MAKINO, Miyoko. "A ornamentação alegórica". In: WITTER, José Sebastião (Ed.); BARBUY, Heloisa (Org.). Museu Paulista, um Monumento no Ipiranga. São Paulo: FIESP/CIESP/SESI/SENAI/IRS, 1997.

MAKINO, Miyoko. "Ornamentação do Museu Paulista para o Primeiro Centenário: construção de identidade nacional na década de 1920". Anais do Museu Paulista: História e Cultura Material, São Paulo, n.10/11, pp. 167-195, 2002/2003.

MARINS, Paulo César Garcez. Nas matas com pose de reis: a representação de bandeirantes e a tradição da retratística monárquica européia. Revista do Instituto de Estudos Brasileiros, São Paulo, v. 44, p. 77-104, 2007.

MARINS, Paulo César Garcez. Tensões sociais da gestão da metrópole. In CAMPOS, Candido Malta; GAMA, Maria Lucia Helena; SACCHETTA, Vladmir (orgs.). São Paulo, metrópole em trânsito: percursos urbanos e culturais. São Paulo: Editora Senac, 2004.

MARINS, Paulo César Garcez. O Parque do Ibirapuera e a construção da identidade paulista. Anais do Museu Paulista: História e Cultura Material, São Paulo, , v. 6/7 (1998-1999). Editado em 2003, p.9-36.

MARINS, Paulo César Garcez. Habitaçãoe vizinhança: limites da privacidade no surgimento das metrópoles brasileiras. In NOVAIS, Fernando A. (Coord.); SEVCENKO, Nicolau (Org.). História da vida privada no Brasil, vol. 3 - República: da Belle Époque à Era do Rádio. São Paulo: Companhia das Letras, 1998, p. 131-214.

MARINS, Paulo César Garcez. Obras de arte em um museu de história: desafios metodológicos na documentação de acervo do Museu Paulista da USP. In: I Seminário Internacional Arquivos de Museus e Pesquisa, 2009 (MAGALHÃES, Ana Gonçalves, org.). São Paulo: Museu de Arte Contemporânea da USP, 2010, p. 72-82.

MARTINS, Ana Luiza. Revistas em revista:Imprensa e práticas culturais em tempos de República. São Paulo: Edusp, Fapesp, Imesp, 2001.

MARTINS, Ana Luiza. BARBUY, Heloísa. Arcadas: história da faculdade de direito da Universidade de São Paulo. São Paulo: Companhia Melhoramentos: Alternativa Serviços Programados, 1999.

MATTOS, Cláudia Valladão de. Da palavra à imagem: sobre o programa decorativo de Affonso Taunay para o Museu Paulista. Anais do Museu Paulista: História e Cultura Material, São Paulo, n. 6/7, p 123-145 (1998/1999).Editado em 2003.

MENESES, Ulpiano T. Bezerra de. A fotografia como documento. Robert Capa e o miliciano abatido na Espanha: sugestões para um estudo histórico. Tempo, Niterói, v. 7, n. 14, p. 131- 142, 2003.

MENESES, Ulpiano T. Bezerra de (org.). Como explorar um museu histórico. São Paulo: Museu Paulista/USP, 1992.

MENESES, Ulpiano Toledo Bezerra de. O Salão Nobre do Museu Paulista e o teatro da História. In: Às Margens do Ipiranga, 1890-1990 (catálogo de exposição). São Paulo: Museu Paulista-USP, 1990. 
MENESES, Ulpiano Bezerra de. Museu Paulista. Estudos Avançados, São Paulo, v. 8, n. 22, p. 573-578, 1994.

MENESES, Ulpiano T. Bezerra. Fontes visuais, cultura visual, história visual. Balanço provisório, propostas cautelares. Revista Brasileira de História, São Paulo, v. 23, n. 45, p. 11-36, 2003.

MONTEIRO, John M. Tupis, Tapuias e a História de São Paulo. Revisitando a velha questão guaianá. Novos Estudos. CEBRAP, São Paulo, v. 34, p. 125-135, 1992.

MONTEIRO, Michelli Cristine Scapol. Fundação de São Paulo, de Oscar Pereira da Silva: a construção de uma representação urbana na pintura histórica. XXVI Simpósio Nacional de História- Anais, São Paulo, 2011.

MONTEIRO, Michelli C. Scapol. Uma interpretação da história do Brasil nas telas de Oscar Pereira da Silva para a Vila Penteado. In 110 anos da Vila Penteado. São Paulo: FAUUSP, 2012 (no prelo).

MORAES, Fábio Rodrigo de. Uma coleção de história em um museu de ciências naturais: o Museu Paulista de Hermann Von Ihering. Relatório (Iniciação científica), Museu Paulista, 2006, inédito.

MORAES, Fabio Rodrigo de. Uma coleção de história em um museu de ciências naturais: o Museu Paulista de Hermann von Ihering. Anais do Museu Paulista: História e Cultura Material,São Paulo, v. 16, p. 203-233, 2008.

MOSTRA do Redescobrimento: Arte XIX, Nelson Aguilar, organizador/ Fundação Bienal de São Paulo - São Paulo: Associação Brasil 500 Anos Artes Visuais, 2000.

MOTA, Lúcio Tadeu. O Instituto Histórico e Geográfico Brasileiro e as propostas de integração das comunidades indígenas no estado nacional. Diálogos, Maringá, v. 2, n. 2, p. $149-175,1998$

MOURA, Esmeralda Blanco B. de. Bandeirantes do progresso: imagens do trabalho e do trabalhador na cidade em festa. São Paulo, 25 de janeiro de 1954. Revista Brasileira de História, São Paulo, v. 14, n. 28, p. 231-246, 1994.

MUSEO Histórico Nacional (Manrique Zago, dir.; Juan José Cresto, coord.). Buenos Aires: M. ZagoEdiciones, c1997.

NASCIMENTO, Ana Paula. Espaços e a representação de uma nova cidade: São Paulo (1895-1929).Tese (doutorado) - Faculdade de Arquitetura e Urbanismo, Universidade de São Paulo, São Paulo, 2009.

NORA, Pierre e AGERON, Charles-Robert. Les lieux des mémoire. Gallimard, 1997.

NORA, Pierre. Entre Memória e História: a problemática dos lugares. Revista Projeto História,São Paulo, no 10, 1993, p. 7-28.

OLIVEIRA, Cecília Helena de Salles. Museu Paulista: espaço de evocação do passado e reflexão sobre a história. Anais do Museu Paulista: História e Cultura Material, São Paulo, n.10/11, p. 105-126, 2002/2003. 
OLIVEIRA LIMA, Manuel de. Obra seleta. Rio de Janeiro: Instituto Nacional do Livro, 1971.

PESAVENTO, Sandra Jatahy. Em busca de uma outra história: imaginando o imaginário. Revista Brasileira de História, São Paulo, n. 9, v. 15, p.9-28, 1995.

PEREIRA, Paulo Cesar Xavier. Espaço, Técnica e Construção: o desenvolvimento das técnicas construtivas e a urbanização do morar em São Paulo. São Paulo: Nobel, 1988.

PRADO, Eduardo. Coletâneas. São Paulo: Escola Tipográfica Salesiana, 1904.

PRADO, Maria Ligia Coelho. Política e nação na pintura histórica de Pedro Américo e Juan Manuel Blanes. Anais do Museu Histórico Nacional, Rio de Janeiro, 39, 147-166, 2007.

QUARENTA, Ednilson. Apóstolo pregresso e as alegorias da fundação: Anchieta, um mito fundador no IV Centenário da Cidade de São Paulo. Tese (doutorado), Faculdade de Filsofia, Lestras e Ciências Humanas, Universidade de São Paulo, São Paulo,2009.

ROSSI, Mirian Silva. Circulação e mediação da obra de arte na Belle Époque paulistana. Anais do Museu Paulista: História e Cultura Material, São Paulo, v. 6/7. p.83-119 (1998-1999). Editado em 2003.

ROSSI, Mirian Silva. Organização do campo artístico paulistano 1890-1920. Dissertação (Mestrado) - Faculdade de Filosofia, Letras e Ciências Sociais, Universidade de São Paulo, São Paulo, 2001.

SALIBA, Elias Thomé. Histórias, memórias, tramas e dramas da identidade paulistana. In:História da Cidade de São Paulo: a cidade na primeira metade do século XX (18901954) (Paula Porta, org.). São Paulo: Paz e Terra, 2004.

SALGUEIRO, Valéria. A arte de construir a nação - pintura de história e a Primeira República. Estudos Históricos, Rio de Janeiro, v. 30, p. 3-22, 2002.

SALGUEIRO, Valéria. Construindo a origem, as virtudes e os heróis na pintura de história: o caso da obra A Morte de Estácio de Sá, de Antônio Parreiras.Anais do Museu Histórico Nacional, Rio de Janeiro, 39, p. 129-146, 2007.

SALGUEIRO, Valéria. Antonio Parreiras: notas e críticas, discursos e contos: coletânea de textos de um pintor paisagista. Niterói: EdUFF, 2000.

SCHWARCZ, Lilia Moritz.O espetáculo das raças: cientistas, instituições e questão racial no Brasil (1870-1930). São Paulo: Companhia das Letras, 2011.

SCHWARCZ, Lilia Moritz. A natureza como paisagem: imagem e representação no Segundo Reinado. Revista USP,São Paulo, n. 58, p. 6-29, $2003 .$.

SCHWARCZ, Lilia Moritz. Retrato em branco e negro: jornais, escravos e cidadãos em São Paulo no final do século XIX. São Paulo: Companhia das Letras, 1987.

SEGAWA, Hugo. Prelúdio da Metrópole - arquitetura e urbanismo em São Paulo na passagem do século XIX ao XX. São Paulo: Ateliê Editorial, 2000. 
SEGAWA, Hugo. São Paulo, veios e fluxos: 1872-1954. História da Cidade de São Paulo: a cidade na primeira metade do século XX (1890-1954) (Paula Porta, org.). São Paulo: Paz e Terra, 2004.

SINGH Júnior.,Oséas. A Partida da Monção: tema histórico em Almeida Júnior. Dissertação (Mestrado), Instituto de Filosofia e Ciências Humanas, Universidade Estadual de Campinas,Campinas, 2004.

SOARES JÚNIOR, Rodrigo. Jorge Tibiriçá e sua época. São Paulo: Companhia Editora Nacional, 1958.

SODRÉ, Nelson Werneck. História da imprensa no Brasil. Rio Janeiro: Mauad, 1999.

STAUFFER, David Hall. Origem e Fundação do Serviço de Proteção aos Índios (18891910). Revista de História, São Paulo, no.37, 1959; no.43, 1960; no. 44, 1960; no. 46, 1961.

TARASANTCHI, Ruth Sprung, Oscar Pereira da Silva. São Paulo: Empresa das Artes, 2006.

TAUNAY, Affonso d' E. Guia da Secção Histórica do Museu Paulista. São Paulo: Imprensa Official do Estado, 1937.

VASCONCElOS, Simão de. Crônica da Companhia de Jesus. Petrópolis: Editora Vozes, 1977.

VIOLLET-LE-DUC, Eugène Emmanuel, Histoired'undessinateur: commentonapprend à dessiner. Paris: Berger-Levrault, 1978. 